ANA FLÁVIA PIRES LUCAS D’OLIVEIRA

\title{
VIOLÊNCIA DE GÊNERO, NECESSIDADES DE SAÚDE E USO DE SERVIÇOS EM ATENÇÃO PRIMÁRIA
}

Tese apresentada à Faculdade de Medicina da Universidade de São Paulo para obtenção do título de Doutor em Medicina.

São Paulo 
ANA FLÁVIA PIRES LUCAS D’OLIVEIRA

\section{VIOLÊNCIA DE GÊNERO, NECESSIDADES DE SAÚDE E USO DE SERVIÇOS EM ATENÇÃO PRIMÁRIA}

Tese apresentada à Faculdade de Medicina da Universidade de São Paulo para obtenção do título de Doutor em Medicina.

Área de concentração: Medicina Preventiva Orientadora: Profa. Dra. Lilia Blima Schraiber

São Paulo

2000 
Um trabalho deste tipo é, por um lado, radicalmente solitário. Escrever é uma aventura geralmente "solo", e esta solidão extrema é uma das dificuldades do processo, porque nos coloca de frente com nossos defeitos tão singulares e nossas incapacidades, enfim, nossa imperfeição.

Por outro lado, é totalmente impossível escrever um trabalho deste tipo isoladamente. Portanto, se sou o sujeito que escreveu esta tese (na dupla acepção da palavra), o seu conteúdo revela e reflete a contribuição de uma ampla rede de relações na qual estou envolvida e à qual agradeço sinceramente, pois é a graça e o sentido da vida.

Agradecer me parece pouco neste momento. Quero tanto agradecer como oferecer o resultado e dar o crédito para o esforço de tanta gente, esperando que o trabalho que agora encerro possa gerar novas ações e palavras, inserindo-se nesta rede e encontrando interlocutores.

Obrigada:

À Lilia Blima Schraiber, que me propiciou não só o privilégio de poder contar com uma orientadora gentil, presente e competente, mas também o prazer de conviver com uma figura humana maravilhosa.

Ao José Ricardo Ayres, Paulo Mangeon Elias e Sílvia Pimentel, pelas contribuições na banca de qualificação e pela disponibilidade e generosidade,

Ao pessoal do campo: Gisele, Maria Flávia, David, Brenno, Bruna, e especialmente à Sílvia, companheira de pesquisa durante todo o processo,

Aos funcionários e equipe técnica do CSE, especialmente às auxiliares de enfermagem e aos médicos que gentilmente se deixaram observar, e aos meus colegas sanitaristas que arcaram com uma parcela do meu trabalho durante a 
confecção da tese. À Diane e ao Ricardo Góes, pelo apoio logístico de todas as horas, e ao Ricardo Teixeira e Ivan França Jr., pelo papo de todas as horas.

À nossa equipe atual de estudo e pesquisa: Márcia, Milena, Elaine, Heloísa, Andréa, André, Ciça, Juliana e quem mais chegar, com a esperança de que possamos construir e trocar ainda muito mais,

Às usuárias do CSE, especialmente às que concordaram em ser observadas e mais especialmente ainda, à Marluce, Rosana, Cláudia, Carla e Elza, que deram seus depoimentos de vida e se dispuseram a um trabalho de duras recordações,

Aos funcionários do Departamento de Medicina Preventiva, em especial Dodo, Djanira e Edileuza pelo cuidado e pela paciência.

Aos meus pacientes, meus alunos e meus professores, pelas lições diárias.

À quem me alimenta no dia a dia com carinho e alegria, minha família e meus amigos. Anna Helena, Eliana, Vera, Nani, Jarbas, Simone, Arthur, Verônica,, Marcinha, Marina, André Motta, Carola, e muitos mais, que já foram citados e outros que ainda falta citar. Um beijo especial para as crianças, esperanças sempre presentes, e para o Flávio, Ricardo Bruno e Paulo M., ausências também sempre tão presentes. 


\section{SUMÁRIO}

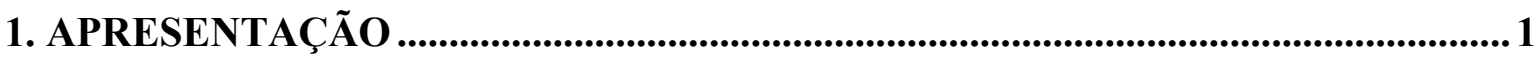

2. VIOLÊNCIA CONTRA A MULHER E RELAÇÕES DE GÊNERO .......................21

2.1. A definição do problema: primeiras delimitações........................................ 21

2.2. Relações de gênero e violência: da violência contra a mulher à violência de gênero

2.3. Violência de gênero como violação dos direitos humanos: os direitos humanos das mulheres

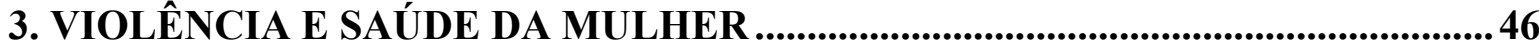

4. O DESENHO DO ESTUDO E O TRABALHO DE CAMPO ...................................61

4.1. A observação das atividades assistenciais................................................. 69

4.2. Os prontuários e o uso dos serviços........................................................ 71

4.3. As entrevistas individuais com mulheres em situação de violência ............ 73

4.4. As entrevistas individuais com os profissionais médicos e de enfermagem. 76

\section{PRINCÍPIOS DE INTERPRETAÇÃO E ANÁLISE DO MATERIAL} EMPÍRICO

5.1. Linguagem, poder e violência nos serviços de saúde ................................. 78

5.2. As práticas em saúde : trabalho em saúde e interação ............................... 87

5.3. Medicalização - a linguagem da doença ................................................. 96

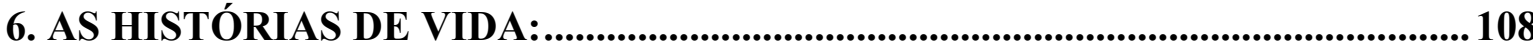

APRESENTANDO AS PERSONAGENS

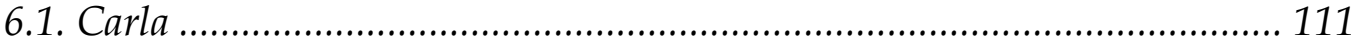

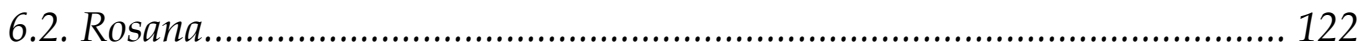

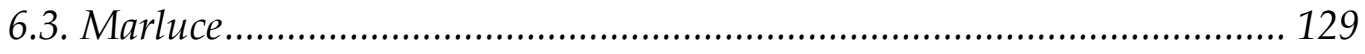

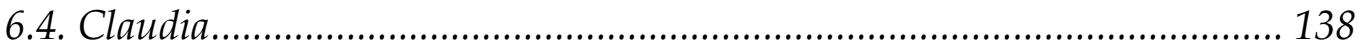

7. CONDIÇÕES DE EMERGÊNCIA, ACOLHIMENTO E RESPOSTA: A OBSERVAÇÃO DIRETA.

A OBSERVAÇÃO DIRETA

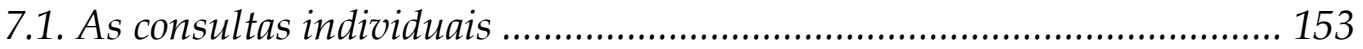

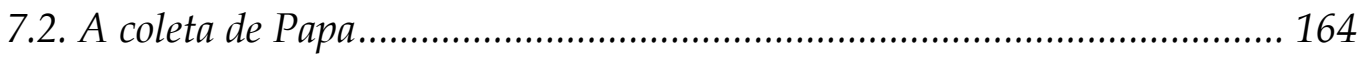

7.3. A vagina larga: relações de gênero e sexualidade medicalizada................. 168 
7.4. Mulheres cuidam de mulheres

7.5. Mulheres falam dos homens..

7.6. Situações de violência: o trágico na condição de gênero

8. CONDIÇÕES DE EMERGÊNCIA, ACOLHIMENTO E RESPOSTA: OS PRONTUÁRIOS

9.VIOLÊNCIA E SAÚDE: OS DEPOIMENTOS DE PROFISSIONAIS E USUÁRIAS.

9.1. Os profissionais de saúde.

9.2. As usuárias.... 236

10. CONSIDERAÇÕES FINAIS.

251

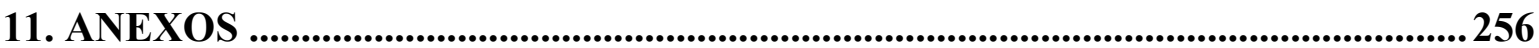

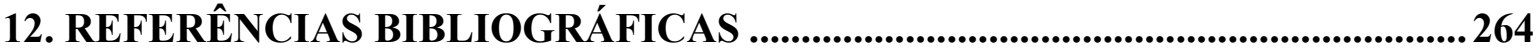




\section{RESUMO}

D’OLIVEIRA, A.F.P.L. Violência de Gênero, Necessidades de Saúde e Uso de Serviços de Saúde em Atenção Primária. São Paulo, 2000 279pp. Tese (Doutorado) Faculdade de medicina, Universidade de São Paulo.

Estudou-se a forma usual como a violência vem se apresentando e é ou não trabalhada no interior dos serviços de saúde de atenção primária. A partir da interação que se estabelece entre as usuárias e profissionais desses serviços busca-se as condições que propiciam ou obstaculizam a emergência, o acolhimento e a proposta de intervenção sobre a questão no interior de um serviço de saúde. Foi estudado um serviço específico que tinha como característica ter o PAISM implantado através de observação direta de atividades assistenciais, análise do registro em prontuário e do perfil de consumo do serviço e entrevistas com usuárias e profissionais. Encontrou-se a emergência de conflitos em torno das relações de gênero e violência de gênero no registro tanto em prontuários como na observação direta. Observou-se que as possibilidades de emergência destes conflitos estão ligadas aos canais de comunicação abertos e à possibilidade de antever alguma resposta para o exercício profissional. Discute-se os riscos trazidos pela possível medicalização e psiquiatrização da violência e a importância de um trabalho intersetorial e multidisciplinar para apreender e trabalhar o problema. 
GENDER VIOLENCE, HEALTHCARE NEEDS AND THE USE OF HEALTHCARE SERVICES

The purpose of this paper is to identify the usual ways in which violence has been manifesting itself and how health services deal with it -- or fail to do so. It tries to understand the relation that is established between female users and the professionals who work at these healthcare services with regard to the problem of violence against women as a form of demand capable of generating the production of healthcare. This comprehension has made it possible to understand the conditions that either enable or stand it the way of the manifestation, the provision of care and the intervention proposal relative to the issue within healthcare services. The risks that result from the possible medicalization of violence are also discussed, as well as the importance of interdisciplinary and intersectorial work in both understanding and dealing with the problem. 
Aquele que diz TU não tem coisa alguma por objeto. Pois, onde há uma coisa há também outra coisa; cada Isso é limitado por outro Isso. O Isso só existe na medida em que é limitado por outro Isso. Na medida em que se profere o Tu, coisa alguma existe. $\mathrm{O} T u$ não se confina a nada. Quem diz Tu não possui coisa alguma, não possui nada. Ele permanece em relação. (BUBER, s/data) 


\section{Apresentação}

A violência contra a mulher é uma questão social e política que vem sendo estudada há mais de vinte anos por disciplinas variadas como a sociologia, o direito, a psicologia e a antropologia. Tem sido objeto de luta para o movimento social e tem inspirado o planejamento e implantação de políticas públicas para sua redução e controle. Nos últimos 10 anos, este problema vem sendo remetido também à área da saúde pública, tanto pelo movimento feminista, RED DE SALUD DE LAS MUJERES LATINOAMERICANAS Y DEL CARIBE (1996), como por organismos internacionais, OMS/OPS (1998) e profissionais de saúde CAMPBELL,(1995), AMERICAN MEDICAL ASSOCIATION, (1992). Esta relação com a saúde coloca a violência como questão para a prevenção e a assistência de "casos". Passa também a ser identificada uma violência cometida pelos próprios serviços de saúde CLADEM/CRLP (1998).

O conhecimento acumulado sobre o assunto demonstra a alta freqüência do problema, sua importância para a saúde pública e também as várias lacunas e imprecisões existentes em sua compreensão do ponto de vista da saúde. Entre estas imprecisões, esperadas em área tão recente de conhecimento e prática, estão as dificuldades de definição do que venha a ser "violência contra a mulher", ou "violência de gênero, a ausência de uma rede explicativa estabelecida e o incipiente estabelecimento e avaliação de estratégias de trabalho para a prevenção e assistência ao problema ROSENBERG; FENLEY, (1991), NATIONAL RESEARCH COUNCIL(1996), STARK;FLITCRAFT, (1996).

Dirigir-se ao tema da violência contra a mulher da perspectiva da saúde significa diferenciar e buscar as intercomunicações entre a violência contra a mulher, a doença e a saúde. Esta aproximação permite trazer elementos para a reflexão em dois sentidos: 
1. Para o campo interdisciplinar de estudos e práticas que busca compreender e atuar contra a violência como uma necessidade social das mulheres

2. Para a saúde em particular e suas práticas assistenciais repensadas criticamente quanto ao modo de acolher as mulheres, o que porá em relevo questões de organização e gestão dos serviços de saúde.

No primeiro caso, a temática da violência permite retrabalhar, da perspectiva cultural e ética, certos conceitos da área da saúde que podem ser úteis no planejamento e implantação de programas D’OLIVEIRA; SENNA (1996), D’OLIVEIRA; SCHRAIBER, (1999). No segundo caso, permite lançar um olhar sobre a violência institucional, ou estrutural, SOUZA, (1992); MINAYO, (1994); CLADEM/CRLP (1998), DINIZ, (1996), DINIZ; D’OLIVEIRA, (1998), D'OLIVEIRA; SCHRAIBER, (1999) perpetrada pelos próprios serviços, levantando novos desafios relacionados às formas de assistência. Ao discutir a emergência e acolhimento de questões relacionadas à violência contra a mulher nas práticas assistenciais em saúde, acaba-se por colocar em pauta as formas de cuidado, direcionando luz para as formas atuais de (des) respeito ao outro no interior das próprias práticas, originando sérias questões ao mesmo tempo éticas e técnicas para a assistência em saúde em geral e não apenas relativas ao impacto da violência sobre a saúde.

Se a introdução de um tema tradicional do feminismo no campo da assistência à saúde traz um grande aumento de legitimidade para a questão, também encerra novos dilemas, decorrentes das conseqüências práticas da abordagem de tema tão eminentemente privado e relacional para o trabalho em saúde. Ao transformar uma questão privada em social, e solicitar soluções em termos de políticas públicas, o movimento de mulheres pressiona o Estado no sentido da implementação de ações concretas sobre o problema, originalmente restrito à esfera privada. Há aqui duas passagens importantes: 
1. do privado ao público como questão, e então,

2. de problema social à questão de políticas públicas, a serem incorporadas e trabalhadas por instituições do Estado.

Estas passagens não são simples nem automáticas e encerram contradições e riscos. Para exemplificá-los, vamos recuperar rapidamente as origens e algumas das problemáticas levantadas pela primeira política pública implementada para o combate à violência contra a mulher, as Delegacias de Defesa da Mulher (DDM), que têm já quase 15 anos de funcionamento e podem nos servir como exemplo para o exame do problema do ângulo da saúde, guardadas as diferenças marcantes entre ações policiais e jurídicas, por um lado, e de saúde, por outro.

\section{As políticas públicas dirigidas à violência contra a mulher no Brasil}

No Brasil, desde os primeiros anos da década de 80, surge um ativo movimento feminista que tem como suas principais bandeiras a violência e a saúde da mulher. Nesta época, o assassinato de algumas mulheres de classe média por seus maridos ou ex-maridos é acompanhada de intensa mobilização para evitar a absolvição dos criminosos com base nos argumentos de "legítima defesa da honra" e caráter "passional" do crime, como era comum ocorrer então (VERARDO, 1995). Acusando a impunidade reinante para os crimes de violência conjugal e a transformação da vítima em ré, por seu julgamento moral, o movimento passa a solicitar que os crimes cometidos nas relações íntimas tenham um tratamento equivalente aos crimes de mesma natureza ocorridos entre desconhecidos, defendendo que os direitos deveriam ser iguais para todos.

Enunciado o problema da violência conjugal, o que era uma situação comum mantida em segredo no mundo privado passa a ganhar o espaço público e intervenções começam a ser propostas. Várias iniciativas de apoio às 
mulheres são organizadas por grupos feministas em diversas cidades do país: COMISSÃO DE VIOLÊNCIA CONTRA A MULHER (posteriormente, SOS-MULHER), no Rio de Janeiro; sOS-MUlHer, em São Paulo e Porto Alegre; CENTRO DE DEFESA DOS DIREITOS DA MULHER, em Belo Horizonte; e SOS AÇÃO-MULHER, em Campinas. (BRANDÃO, 1996). Estes serviços, que funcionavam com o trabalho de ativistas voluntárias, buscaram assistir às mulheres que sofriam violência doméstica e tiveram várias dificuldades e precariedades institucionais, o que gerou avaliações diversas VERARDO, (1995), GREGORI, (1992). Seu objetivo, no entanto, foi cumprido: a violência contra a mulher, em uma de suas formas mais comuns, a violência conjugal, era agora uma questão pública.

Enunciado o problema, o movimento de mulheres inicia parcerias com o Estado no sentido da implementação de políticas para combatê-lo. Em 1983 é criado o CONSELHO ESTADUAL DA CONDIÇÃO FEMININA, em São Paulo, e em 1985 é criado o CONSELHO NACIONAL DOS DIREITOS DA MULHER e a primeira DELEGACIA DE DEFESA DA MULHER (DDM), também no Estado de São Paulo. A instituição das DDM permitiu que delegacias especiais para crimes contra a mulher, com funcionárias exclusivamente mulheres e devidamente treinadas fossem implantadas, dando grande visibilidade à questão. O Brasil foi o primeiro país no mundo a propor este tipo de intervenção, pressionado pela constatação de que a desvalorização do crime e a impunidade dificultava às mulheres prestar queixas de estupro e violência conjugal nas delegacias de polícia existentes, intimidadas por ironias e pelo machismo. Hoje em dia, já são mais de cem DDMs só no Estado de São Paulo, mais de 180 em todo o país, BRANDÃO, (1996), e inúmeras delegacias do mesmo tipo em diversos países da América Latina RED DE SALUD DE LAS MUJERES LATINOAMERICANAS Y DEL CARIBE (1996).

As DDM foram o primeiro grande recurso no combate público à violência contra a mulher, e especialmente à violência conjugal, no país. Seu caráter é basicamente policial: detectar transgressões à lei, averiguar sua procedência e criminalizar a violência doméstica de acordo com a lei federal. 
Note-se ao ser é enunciada como desvio da normatividade social, e não mais uma norma aceita socialmente, a violência doméstica é interpretada em primeiro lugar como um crime. O crime é uma transgressão da norma social aceita, e, como tal, enquadra-se na lei e é passível de responsabilização e punição. O que passa a ocorrer é que as leis existentes para coibir abusos nas relações interpessoais na esfera pública passam a ser utilizadas também por mulheres para denunciar homens extremamente íntimos, geralmente seus parceiros ou ex-parceiros, por crimes como ameaça, lesão corporal ou injúria. No entanto, ainda que a lei a princípio seja feita para ser aplicada a toda e qualquer relação interpessoal, quando são usadas na esfera das relações conjugais e familiares, observam-se muitas dificuldades. $\mathrm{O}$ crime de lesão corporal leve, por exemplo, tem características e sentidos muito diversos, quando se trata da briga de dois desconhecidos em um bar ou das relações cotidianas de um casal. Esta diversidade não significa que um crime seja mais suportável que o outro, mas, sim, que assumem significados diversos para os indivíduos presentes e para a sociedade.

Dirigir a questão da violência doméstica ao judiciário acabou por tornar aparente que os crimes cometidos por pessoas muito próximas das vítimas, diferente do que se pensava a princípio, ainda que sejam crimes como todos os outros, têm uma configuração própria e necessitam regulação penal e também civil específicas, além de um compromisso do Estado em garantir o acesso a estes mecanismos e seu efetivo funcionamento. Diversos países latinoamericanos, de acordo com o compromisso assumido em diversas Conferências Internacionais promovidas pelas Nações Unidas, aprovaram nos últimos anos leis específicas para a violência doméstica RED DE SALUD DE LAS MUJERES LATINOAMERICANAS Y DEL CARIBE, (1996), mas o Brasil ainda não realizou este passo. Em nossa opinião, esta necessidade confirma o caráter particular dos crimes ocorridos no interior de relações de intimidade e que tem em suas raízes a desigualdade nas relações de gênero. 
No Brasil, por exemplo, apesar das DDM e do aumento importante de denúncias que elas propiciaram, a impunidade continua; muitos processos não são instaurados, poucos chegam ao julgamento e o número de condenados é ínfimo. Esta ineficácia das DDM deve ser analisada com cuidado, porque pode iluminar alguns aspectos importantes para pensarmos a incorporação do tema pela saúde. A retirada da queixa, procedimento muito comum, algo em torno de $70 \%$ dos registros, em um estudo específico realizado no Rio de Janeiro (BRANDÃO, 1996), é um fato recorrente que vem minando a credibilidade da estratégia, já que reforça o mito de que as mulheres não "querem" mudar a sua situação, e "gostam de apanhar". Esta aparente "falta de consciência" das mulheres sobre seus direitos, entretanto, esconde uma lógica diversa daquela proposta pela instituição das DDMs e do próprio movimento feminista.

Apoiada em BRANDÃO (1996), que diferencia a lógica institucional das DDMs da lógica moral que as mulheres adotam em sua relação com estes serviços, pode-se dizer que, se para a polícia a queixa tem que ser tratada institucionalmente do ponto de vista penal, isto é, na linguagem jurídica do crime, as mulheres que se queixam raramente consideram estas queixas como passíveis de criminalização, mas, sim, como um conflito familiar de ordem moral. Tendo as Delegacias como único recurso visível de enfrentamento do problema, bastante legitimada entre as classes populares e extremamente divulgado nos últimos anos, especialmente pelo movimento feminista, como um lugar de defesa dos direitos da mulher, as mulheres buscam nelas uma mediação do conflito privado.

A concepção do que seja exatamente "direitos" ou "interesses" das mulheres, entretanto, não é a mesma para todos os grupos sociais, e uma boa parte da demanda dirigida às delegacias são pedidos de intervenções na área civil, como soluções legais para a separação, ou outras expectativas, tais como "dar uma dura" no marido, que não se enquadram na função primária da polícia penal, tal como compreendido pela lógica institucional das trabalhadoras das delegacias, isto é, verificar e apurar o crime. Estas demandas 
compõem, entretanto, a concepção do significado de direitos para as mulheres que fazem uso destes serviços. As mulheres que procuram a delegacia têm uma visão global de seu problema, atribuindo geralmente à sua situação um sentido bem mais complexo do que os crimes tipificados em lei, como a lesão corporal. A própria agressão física pode não ser o problema principal para algumas delas, já que a perturbação da ordem familiar que ela indica pode ser bem mais importante. Brandão nota, entretanto, que assim que as mulheres pesquisadas por ela percebem que sua "queixa" não pode ser reconhecida pela instituição policial, tratam de tentar adequar sua demanda à linguagem jurídica do crime, denunciando, por exemplo, uma "ameaça", para legitimar a reclamação de um marido que está perturbando a ordem doméstica com amantes e bebedeiras, já que o problema enunciado desta forma não se enquadra em nenhum crime previsto em lei.

Por outro lado, as trabalhadoras das Delegacias tampouco consideram as queixas como pertencentes ao que entendem como seu campo de atuação, já que, muitas vezes estas não podem ser enquadradas em crimes tipificados na legislação e porque percebem a intenção das mulheres por vezes como distante da idéia de punir seus parceiros conforme previsto em lei. A retirada da queixa, um procedimento comum, como referido, resulta, segundo BRANDÃO, da interação das "vítimas", hesitantes em criminalizar penalmente o parceiro que está perturbando a ordem doméstica, com as policiais, que percebem nas queixas uma situação mais "social" ou "psicológica", desqualificando-a como crime. Nesse sentido, a nosso ver, as profissionais da delegacia e as mulheres usuárias compartilham, por motivos diversos, de igual interpretação do fato: a violência doméstica não lhes parece uma ocorrência passível de criminalização, a não ser talvez em casos muito extremos. Daí o encontro que se verifica no ato de retirada da queixa. Este encontro contrasta fortemente com a proposta de política pública reivindicada pelo movimento feminista, assumida pelo Estado e materializada nas DDM, que busca justamente tratar estes eventos como crimes passíveis de averiguação e punição, baseada em uma idéia liberal de direitos individuais iguais para todos. Brandão ressalta que esta interpretação da 
retirada da queixa lhe dá um sentido diverso da idéia comum de que este procedimento seria fruto apenas da "falta de consciência" das mulheres de seus direitos ou de sua cidadania, ou de sua submissão, enquadrando o processo como uma ocorrência institucional com base em concepções de direitos diversas.

A retirada da queixa não é, entretanto, percebida pelas mulheres como contraditória ao movimento que as levou a registrá-la. Elas tendem a retomar a negociação com o acusado em uma posição superior à qual se encontravam anteriormente. Na ótica dessas mulheres, a suspensão do processo seria, então, um elemento que poderia favorecer o retorno da reciprocidade rompida, que é muitas vezes o seu interesse principal. Para as mulheres, a queixa, ainda que retirada, "está lá arquivada" e sempre pode ser usada como argumento na negociação conjugal, ainda que para as policiais esta queixa não tenha mais nenhum valor legal.

Por outro lado, a nosso ver, para as trabalhadoras das Delegacias, a retirada da queixa confirma a idéia de que a demanda foi mal dirigida, não estando dentro de sua competência profissional de intervenção. Ainda que compartilhem da idéia de que as situações relatadas não se enquadrem como crime, usuárias e trabalhadoras divergem, portanto, quanto às expectativas de intervenção possível das Delegacias e os resultados alcançados por seu trabalho. Tal divergência quanto ao sentido do trabalho profissional, para as mulheres usuárias das DDMs e para as mulheres profissionais, encontra um paralelo com o que ocorre na saúde, o que nos possibilita compreender melhor as próprias DDMs e os serviços de saúde em sua ação de serviço, como mostraremos melhor a seguir.

A partir dos anos 90, a violência passa a ser remetida também à área da saúde pública e, mais especificamente, aos serviços de saúde. Temos por hipótese que com estes serviços possa ocorrer situação análoga às DDMs, guardadas as devidas especificidades. Além de transgressão da normatividade 
civil - crime -, a violência estará sendo, neste caso, nomeada como causadora de alterações da normatividade vital - doença.

Quais são as possibilidades e limites de remeter a violência contra a mulher para o âmbito dos serviços de saúde?

Se não é exatamente uma demanda pela ação penal diante de um possível crime para os policiais, o sofrimento da mulher em situação de violência tampouco é doença para os médicos e profissionais de enfermagem, a não ser que haja alguma base anatomopatológica objetiva para justificá-lo. Neste último caso, a interpretação de doença por parte da usuária pode ser acolhida como patologia pelos profissionais de saúde, e a violência perde seu sentido e sua importância, tendendo a ser desconsiderada. Do contrário (se não é possível encontrar para a queixa nenhuma patologia que a justifique), esta queixa é desqualificada como social, ou psicológica, e não é acolhida pelo serviço que opera sob a racionalidade biomédica de intervenção, isto é, a doença como alteração de forma ou função do corpo, conforme compreendido pela biomedicina, como alvo da atuação profissional (patologia).

Por outro lado, da perspectiva das mulheres, todo o sofrimento que trazem aos serviços de saúde é potencialmente doença, e como tal pode e deve ser diagnosticado e tratado com base em um saber científico e, portanto, bastante legitimado. Esta nos parece ser a expectativa das mulheres em serviços de saúde, em razão de sua própria constituição como usuárias.

Nossa proposta é discutirr, pois, como se dá a relação entre usuárias e profissionais de saúde, desde o momento em que a mulher em situação de violência percebe o sofrimento como potencial doença e resolve procurar um serviço, até o momento em que segue uma orientação e tem (ou não) sua demanda atendida. $\mathrm{O}$ interior deste processo, a atividade assistencial em saúde, será estudado como o centro desta relação: é ali que é negociado (ou não) o quanto se pode traduzir o sofrimento como doença, e os significados que isto pode ter para os sujeitos presentes. É ali, portanto, que o que foi vivido vem a 
ser percebido como transgressão e violência, ou não, e que as alternativas terapêuticas são negociadas ou impostas.

Como acontece este processo? Quais os seus significados cotidianos para o uso de serviços de saúde e para a vida social das mulheres e famílias em geral? Estas são as perguntas mais gerais que orientam esta investigação.

A área da saúde, assim como a polícia, tem dificuldades em trabalhar questões percebidas como culturais, sociais e até psicológicas. A proposta mais divulgada para o trabalho com o problema nos serviços de saúde é a de detectar a violência contra a mulher por busca ativa de rotina, ou screening, através de questionários simples, curtos e padronizados. Esta iniciativa pode ter o efeito inesperado de, detectada a violência, a demanda ser rejeitada como "nãodoença", porque social, e desqualificada também como tarefa do serviço. As alternativas de intervenção, parcelares e limitadas, podem parecer insuficientes, e a falta de controle sobre a sua efetivação exasperar os profissionais. Por outro lado, a questão pode ser percebida como patologia, o que também levanta questões, por reduzir ao corpo individual aquilo que é, por definição, das interações humanas e por conceder ao profissional (expropriando da mulher) o juízo final sobre o caso, arbitrando unilateralmente o que é patológico e o que não é, bem como as formas de cuidado que devem ser tomadas. A solução pode acabar, portanto, por ter um impacto sobre o problema menor ou muito diverso do esperado, como parece estar ocorrendo com as DDMs.

Se as DDMs têm problemas em lidar com o problema da violência em seu interior, por tematizarem apenas uma dimensão restrita da questão (o crime), os serviços de saúde parecem também abordá-lo de forma parcial (a doença) .

Sem lugar definido ou reconhecido no âmbito das práticas que poderiam acolher demandas e necessidades relacionadas à violência, esta situação experimentada pelas mulheres, que entendemos ligada às questões de gênero, não são reconhecidas no interior do discurso competente da lei ou da doença. 
Este vivido (a situação de violência doméstica) não é, por parte dos profissionais, nomeado desta forma como demanda a ser acolhida pelos dois discursos competentes aqui tratados: nem pela lei e nem pela medicina. Mas as mulheres, com base em suas experiências pessoais e na divulgação pública que vem sendo realizada, especialmente sobre o papel e a importância da queixa à polícia nestes casos, vêm tratando de, a partir de discursos competentes que lhes são alheios, encontrar maneiras de apropriar-se dos canais de comunicação existentes e expressar suas necessidades publicamente. Estas instituições serão, a nosso ver, alvo por parte das mulheres de uma tentativa de aproximação neste sentido: sem ser crime, a violência será uma espécie de "transgressão da ordem"; sem ser doença, uma espécie de "transgressão do corpo".

Partimos aqui da idéia de que, sem uma linguagem própria reconhecida para lidar com o problema, privado e sigiloso por tradição, as mulheres realizam um deslocamento discursivo ao enunciá-lo na esfera pública como demanda assistencial. Nas Delegacias de Polícia buscam enunciar seu problema como crime, aproximando-se de uma linguagem "competente": o discurso da lei. Apesar de querer apoio, entretanto, as mulheres não desejam todas as conseqüências da lei, tal como uma possível prisão dos seus companheiros. "Emprestam" a linguagem desejando fins diversos, já que possuem outra lógica, que busca geralmente restaurar a interação e ordenar a família, combatendo a violência.

Ao dirigir-se aos serviços de saúde, buscam da mesma forma enunciar o seu problema como potencial doença, realizando um deslocamento discursivo similar. O diagnóstico de doença pode até ser percebido como um alívio e uma explicação legítima para a situação, acompanhado de uma provável solução, e, portanto, torna-se algo desejado. Assim, uma vez "aceita a queixa", o sofrimento correlato é legitimado, de alguma forma, pelo discurso competente. A doença não penaliza ninguém e não rompe os vínculos familiares. Incide sobre a mulher que busca o serviço, não é sua responsabilidade e legitima seu sofrimento. O diagnóstico de doença poderia até funcionar como estratégia de 
retomada da interação das relações íntimas, assim como vimos que ocorre com o uso das DDMs. É importante ressaltar que perceber desta forma a busca das mulheres àquelas instituições que elas entendem como podendo oferecer algum suporte social (ainda que a sua expectativa de qual seja este suporte possa diferir da lógica institucional) não significa de forma alguma sugerir que esta busca seja incorreta, não sincera ou manipuladora. Acreditamos que as mulheres remetem seu sofrimento real e grave para " lugares" onde vêem genuinamente potencialidades de apoio contra a violência. Não encontrando tudo o que procuram nas DDMs, procuram também outros lugares capazes de ajudá-las a responder de alguma forma ao sofrimento vivido.

Existirá algum espaço próprio para este sofrimento que a princípio não "tem lugar"? Não tem lugar no corpo, não tem lugar no trabalho... Não tem lugar na lei, não tem lugar na patologia...

Sem lugar específico para ser expresso, o sofrimento decorrente da violência é fragmentado e adaptado às linguagens possíveis. Assim, encontrará (com sorte) respostas parciais na lei, na medicina, na psicologia, na família ou na religião, entre outras possibilidades. A articulação entre estes diversos lugares deve ser feito pela própria pessoa que está sofrendo, na ausência de uma organização intersetorial que providencie esta conexão. É importante, portanto, pensarmos o compromisso ético presente na incorporação deste problema para a saúde, já que se trata de questão basicamente relativa à ética das relações interpessoais. A Saúde Pública, que tem tradição em lidar com coordenações intersetoriais na promoção da saúde e prevenção das doenças, tem um importante papel vislumbrado aqui, no sentido de compor a articulação necessária entre os diversos recursos. Por outro lado, este mesmo campo tem uma tradição autoritária, de controle social e disciplinarização da intimidade, que vem sendo criticada e discutida nas últimas décadas FOUCAULT, (1993), COSTA, (1979).

No momento em que o problema passa a ser ativamente dirigido aos serviços de saúde pelo movimento feminista e por associações profissionais, 
cabe aprofundar o conhecimento deste processo no sentido de planejar intervenções para serem realizadas por estes serviços adequadas às necessidades colocadas, buscando aprender com as lições aprendidas com o uso efetivo das DDMs. Qual a reação dos serviços de saúde às "queixas" de doenças? O que significa "aceitar" ou "rejeitar" estas "queixas"? Quais suas conseqüências no cotidiano dos serviços e na vida das usuárias e suas famílias? São estas as perguntas que nos movem aqui.

Este tema, a violência contra a mulher, e os ângulos de visão que utilizaremos (as práticas em saúde vistas como processo de trabalho e interação humana e a noção de gênero) para abordar a violência contra as mulheres, surgiram de minha trajetória profissional como médica sanitarista. Para que fiquem claros a origem das preocupações que orientam este estudo, o problema investigado e as opções teóricas e metodológicas tomadas, inicio o trabalho apresentando-me. Desta forma, busco narrar um processo de pesquisa e de vida, identificando o solo teórico que permitiu o surgimento das perguntas que orientaram meu olhar e que agora procuro sintetizar. Assumo a participação da subjetividade do pesquisador no estudo como inevitável e necessária à produção de conhecimento. Minha apresentação é para permitir o controle intersubjetivo dos efeitos do sujeito que pesquisa no estudo, para que os resultados obtidos possam ser analisados em função dos instrumentos e saberes utilizados na produção de conhecimento e também do sujeito que os operou, o que garantirá a objetividade científica do estudo sem que se perca seu compromisso ético-político. Esta posição corresponde a uma determinada postura epistemológica bastante utilizada, em especial em pesquisa qualitativa (DENZIN, 1994). Este é também o estatuto epistemológico dos estudos sobre o trabalho em saúde nos quais me apóio MENDES-GONÇALVES (1994), SCHRAIBER (1997), AYRES (1997), PEDUZZI(1998).

Explicito, pois, inicialmente, minha experiência profissional e as questões que me levaram a este estudo. 
Em 1987, ingressei na residência médica em Medicina Preventiva na Faculdade de Medicina da USP. Desde aquela época acompanho e compartilho o desenvolvimento de uma linha teórica que já se encontrava consolidada e que acabou por influenciar a minha aproximação da área da saúde coletiva e propiciou uma densa rede conceitual que orienta meu olhar em direção às práticas de saúde como práticas sociais. Dela extraio a perspectiva de centrar meu estudo no recorte dos serviços de saúde e na relação que se estabelece, no interior destes, entre usuários e profissionais como a realização de uma intervenção que é prática de produção de cuidados. Esta produção é, por sua vez, apreendida como reiteração de certos padrões de consumo dos serviços e também por seu papel de criação contínua de necessidades sociais em saúde suportada pelo movimento medicalizador da medicina e seu trabalho social. Aqui, portanto, será central o próprio conceito de medicalização e o modo pelo qual, quer culturalmente, quer produtiva e economicamente, a medicalização está contida na dinâmica da relação serviços de saúde-população, o que será explicitado mais adiante.

Em 1990 tornei-me médica sanitarista, com funções de pesquisa e docência em um serviço de atenção primária, o Centro de Saúde Escola Samuel B. Pessoa (CSE), vinculado à Faculdade de Medicina da USP e à Secretaria de Saúde do Estado. O serviço tem responsabilidade sobre uma área delimitada de atendimento e funciona como campo para ensino e pesquisa. Nesta época iniciava-se uma profunda inflexão no processo de organização do CSE, no sentido de investir em pesquisa em serviço, transformando-o em um laboratório de ações em saúde. Ali buscou-se desenvolver na prática e, ao mesmo tempo, investigar um modelo de organização do trabalho, intitulado ações programáticas em saúde (MENDES-GONÇALVES et al, 1990).

Em meio a uma demanda constante e crescente de cuidados à saúde, de modalidade tipo pronto-atendimento, foi desenvolvido, na última década, um modo de assistência que busca "fazer conviver" o pronto-atendimento com outras formas de cuidado à saúde, revalorizando o referencial epidemiológico e 
outros saberes de cunho coletivo no planejamento, produção e oferta de serviços, articulando as ações individuais àquelas populacionais, princípio da integração sanitária. A idéia principal foi compor uma rede de opções assistenciais em que a assistência médica fosse uma das opções - e não a única em um conjunto maior de cuidados que incluísse ações de promoção da saúde e prevenção de doenças, tais como ações educativas, vigilância epidemiológica, acesso a recursos comunitários, etc., articulando todas elas a um projeto integrador SCHRAIBER et al, (1996). Este projeto pretendeu uma integração antes de tudo de natureza tecnológica, isto é, construir um modo de trabalho e uma modalidade de produção de serviços em que a integralidade das ações fosse o eixo norteador.

Minha tarefa neste coletivo de pesquisadores, gerentes e funcionários, foi auxiliar e, mais tarde, coordenar o planejamento, execução, supervisão e avaliação das ações do Programa de Atenção à Saúde da Mulher. A proposta implementada pretendia trabalhar a integração em dois planos, consoante com seus referenciais teórico-práticos. Em primeiro lugar, em relação ao Programa de Atenção Integral à Saúde da Mulher (PAISM), proposto pelo Ministério da Saúde e Secretaria Estadual de Saúde, a busca de trabalhar cada mulher como um ser integral, para além da dimensão de mãe e puérpera. O PAISM propunha abordar a mulher em todas as faixas etárias e incorporar as dimensões psicológicas e sociais ao trabalho, além da dimensão biológica. Esta abordagem deveria levr em conta e criticar as relações de poder socialmente construídas entre homens e mulheres, e entre usuárias e profissionais de saúde, incorporando a dimensão de gênero como norteadora da assistência D’OLIVEIRA; SENNA (1996), D’OLIVEIRA (1996). Em segundo lugar, a integração foi trabalhada da perspectiva adotada pela proposta em andamento no CSE, de articular saberes e práticas diversos, como as ciências biológicas que amparam a medicina e as ciências humanas que amparam a saúde, o cuidado à saúde da população e o cuidado a cada um dos indivíduos, criando tecnologias integradoras de trabalhos parcelares e compondo diversas formas de cuidado articuladas em um mesmo projeto de trabalho em saúde. 
Esta experiência mostrou-me a dificuldade de "remar contra a corrente": a busca da racionalidade no uso de recursos, a interdisciplinaridade, o estímulo ao autoconhecimento, autocuidado e autonomia, a promoção da saúde, a ênfase nas atividades preventivas, educativas e de atenção à saúde e o trabalho multiprofissional vão exatamente na contramão de uma modalidade de produção de serviços que destaca a saúde como consumo de bens, de preferência de alta complexidade, esgotando-a no consumo individual de assistência médica.

Ficaram claras também as dificuldades de implantar ações educativas interativas em serviços com relações predominantemente unidirecionais, com condições de validade discursivas bastante complexas e pouco permeável ao "paciente", e as dificuldades decorrentes para trabalhar problemas de saúde complexos, que não têm respostas suficientes no saber biomédico e cuja atenção é reivindicada pelo movimento de mulheres, tal como violência, sexualidade, gravidez indesejada, aborto, etc...

Estas questões puderam aparecer, ainda que por vezes timidamente, no trabalho do CSE, mas assim que emergiam, tornavam-se um novo desafio. São questões que dizem respeito a relações entre sujeitos, e a valores, campo em que o saber de base científica que orienta a medicina não pode ter nenhuma certeza. Por isto, seu manejo e intervenção são bastante complexos. Trabalhar questões desta ordem com o tipo de ação orientada para fins que o saber biomédico utiliza, a exemplo do que fazemos com as doenças estabelecidas na nosografia médica, pode nos trazer complicações. O saber anatomopatológico nos fornece uma concepção de normal e patológico que orienta a intervenção clínica, direcionada a restaurar o normal. No caso da fratura, por exemplo, o normal é fácil de definir, e o sujeito, cujo corpo está sendo manipulado, parece não precisar ser consultado para isto. Mas, e no caso de situações, como a violência doméstica, que podem ser o contexto da fratura, onde estaria o normal e o patológico? O saber biomédico não tem indicações acerca de um tema como este, ainda que os profissionais com alguma freqüência arrisquem uma 
indicação. Quem decide sobre isto? Onde fica o normal? Que caminhos levam a ele? Existiria um só normal? Fortemente dependente de valores, e tratando da ética nas relações, o problema da violência, assim como outros citados, chama a atenção para os limites da prática médica tal como constituída contemporaneamente e a necessidade imperiosa da participação de outros sujeitos, saberes e práticas para que no processo histórico se defina a saúde de forma positiva, buscando-se os caminhos para além do puro consumo de medicamentos e manipulação do corpo biológico, e repensando-se toda a prática em saúde.

Apesar das dificuldades, a proposta de organização tecnológica de trabalho implantada insistiu em abrir espaço e acolher estas incômodas questões predominantemente éticas, enunciadas pelo movimento social de mulheres e pelo campo da Saúde Pública como importantes para serem de alguma forma incorporadas e trabalhadas, gerando uma tensão permanente e bastante produtiva no sentido da reorientação do modelo assistencial existente e almejado a cada momento.

No meu trabalho de mestrado, defendido em 1996, eu já procurava as possibilidades colocadas potencialmente na proposta do Programa de Atenção Integral à Saúde da Mulher (PAISM) para a emergência de questões relativas às relações de gênero nos serviços de saúde, especialmente da violência (D’OLIVEIRA, 1996). Sinteticamente, retomarei algumas das questões ali tratadas, que ajudaram na construção do atual estudo.

O PAISM foi uma proposta de Programa de Saúde da Mulher elaborada nos primeiros anos da década de 80 e cuja implantação até hoje é uma reivindicação virtualmente unânime entre profissionais da saúde coletiva e militantes do movimento de mulheres. Para iniciar o estudo da proposta, analisei-a tal como se encontra sistematizada nos documentos que estabelecem as bases programáticas, normas, padronizações e material educativo do Programa de Atenção Integral à Saúde da Mulher do Ministério da Saúde, que 
inspira boa parte destas experiências concretas, além de consultar material acerca do Programa no Estado e Município de São Paulo.

O conceito de atenção integral no PAISM, questão chave para o Programa, foi analisado por meio desses documentos. A integração ali apresentada e pretendida pelo Programa mostrou-se composta, conforme nossa análise, de quatro eixos de saber articulados em propostas de atividades assistenciais: clínico, epidemiológico, psicológico e educativo/comunicacional. O eixo educativo/comunicacional foi escolhido para centrar o exame do PAISM, por seu maior potencial para a emergência de questões de gênero, e foi trabalhado sempre em contraste com os demais. Constatei uma importante tensão interna à formulação do PAISM, gerada, especialmente, por sua forte incorporação do ideário feminista. Tal tensão pode ser atribuída à coexistência de duas idéias, a princípio conflitantes, em sua proposta:

a) a exigência de acesso ampliado, com o direito de maior consumo de todas as ações de saúde necessárias ou desejadas, expandindo a medicalização em todos os sentidos;

b) a busca da crítica ao poder médico e às desigualdades sociais com resgate do saber popular, da autonomia e do autocuidado; exigência, pois, de desmedicalização.

Esta contradição, que podemos chamar da tensão entre o "mais" (consumo ampliado a serviços) e "melhor" (informação, respeito à cultura popular, autonomia para o doente) parece não ser percebida na proposta tal como apresentada em seus documentos principais. No entanto, o trabalho gerencial e assistencial com o programa em ação no CSE já mostrara que esta tensão interna, se é de grande riqueza, pode gerar dificuldades para a execução da proposta por inteiro, com grandes impasses percebidos quando de sua implantação, e, por isto, necessitando ser alimentada pela avaliação da prática e sempre revista. 
O interesse e o trabalho acumulado no estudo da questão da violência contra a mulher iniciaram-se efetivamente em 1994 quando, em uma parceria entre a Faculdade de Medicina da USP e a ONG Coletivo Feminista Sexualidade e Saúde (CFSS), participei de um projeto de pesquisa e intervenção denominado Projeto Integrado de Capacitação e Desenvolvimento de Tecnologia para o Atendimento a Mulheres em Situação de Violência, sob a coordenação de Lilia Blima Schraiber (FMUSP) e Maria José de Oliveira Araújo(CFSS). Pretendia-se atuar sob três ângulos complementares, implementados seqüencialmente: uma série de cursos de capacitação de profissionais de saúde e outros profissionais; a elaboração de um Guia de Serviços para a assistência a mulheres em situação de violência, para mapear possível rede assistencial e incrementar a referência e contra-referência nestes casos (GUIA DE SERVIÇOS, 1996); e a investigação das condições da emergência da violência como questão de saúde na assistência integral à saúde da mulher. Tal linha de trabalho e pesquisa vem se desenvolvendo atualmente em novas frentes. A investigação aqui relatada é parte do terceiro subprojeto do programa inicial, qual seja, o estudo da emergência espontânea do problema violência contra mulheres nas relações de gênero no Programa de Atenção Integral à Saúde da Mulher.

$\mathrm{Na}$ presente pesquisa aprofundo minhas reflexões já iniciadas na dissertação de mestrado, buscando a prática concreta do trabalho em operação, por meio do estudo de um serviço de atenção primária. Desta vez, porém, utilizarei registros em prontuários e dados colhidos na observação direta da assistência, além de depoimentos orais fornecidos por mulheres que sofrem violência, e por profissionais que potencialmente lidam com este sofrimento, para estudar as possibilidades de emergência, acolhimento e trabalho do problema nos serviços. Procuro, pois, agora no cotidiano concreto do trabalho, questões similares ao mestrado. Captado no "retrato" da pesquisa, este cotidiano está aqui, capturado e imobilizado. Esperamos que tal cristalização, entretanto, tenha sido relativizada pela metodologia e referenciais adotados, pois o intuito deste estudo é uma aproximação do trabalho como processo 
interativo, daí o destaque dado a seu recorte de cotidiano prático experimentado no dia-a-dia dos serviços. $\mathrm{O}$ mestrado serve de guia, neste segundo estudo, para tensões, algumas delas já antevistas nos textos e que aqui se desdobram em falas/ações/interações capturadas no interior dos serviços, em uma prática estruturada que revela novas tensões.

Utilizando um referencial teórico semelhante ao do primeiro estudo, e incorporando as contribuição de teóricos da interação e da linguagem HABERMAS (1987); RICOEUR (1976), AUSTIN (1990), BUBBER (s/dt), HELLER (1982), procuro compreender o sentido da medicalização para a mulher em situação de violência e como este sentido se expressa nas relações de interação que se estabelecem com os serviços de saúde, em especial os de atenção primária, em que se assenta a base empírica deste estudo. 


\section{Violência contra a mulher e relações de gênero}

\subsection{A definição do problema: primeiras delimitações}

Para estudarmos as condições de apreensão e transformação do problema violência da perspectiva das necessidades de saúde, com base nas relações estabelecidas entre as mulheres em situação de violência e os serviços de saúde, seria conveniente uma conceituação de violência já definida ou aceita pela maioria da comunidade científica. Ocorre que neste domínio há inúmeras opções e perspectivas disponíveis, a ponto de ser possível caracterizar tal necessidade de conceituação como uma necessidade dos estudos que trabalham com a violência em geral, e não apenas em nosso caso. Neste sentido, devemos eleger aqueles aspectos que mais se ajustem ao recorte pretendido neste estudo. Definir violência é definir o objeto desta investigação, e a conceituação adotada deve ser coerente com as demais opções teórico-metodológicas aqui tomadas. Sistematizaremos, a princípio, algumas das principais opções existentes na conceituação de violência contra a mulher e, a seguir, a forma como este problema assim percebido vem sendo objeto de conhecimento para a saúde a partir dos anos 90. Em nosso estudo, operamos algumas decomposições e recomposições desses recortes em novas delimitações da violência que serão expostas mais adiante, na parte 5.1. Buscamos definir violência como evento social, historicamente construído e sempre relacional, mesmo quando percebido na expressão individual de mulheres e como necessidades de saúde de cada qual.

A palavra violência é polissêmica e tem sido exaustivamente repetida pela mídia e trabalhada por inúmeros pensadores de áreas diversas, especialmente a partir da modernidade. $\mathrm{O}$ termo tem sido usado para indicar desde as formas mais cruéis da tortura e do assassinato em massa até aspectos mais sutis e disseminados, considerados opressivos na vida moderna cotidiana, como as relações sociais, econômicas e as normas culturais. Alguns pesquisadores que estudam a violência 
em geral propugnam definições abrangentes quanto ao contexto social, que levem em conta a chamada "violência estrutural" JOXE, (1981), MINAYO, (1994); HABERMAS, (1980). Outra versão bem abrangente tem sido conceituada como violência simbólica BOURDIEU, (1995).

DOMENACH (1981) chama a atenção para o fato de a violência só recentemente ter se tornado um problema central para a humanidade, apesar de estar presente em toda a história. Este fato é associado à modernidade, que almeja a possibilidade de cidadania, liberdade e felicidade para todos. A partir deste momento, ações antes diversas e que eram percebidas como inevitáveis na ordem do mundo, e mesmo desejáveis, passam a ser nomeadas em conjunto como violência e combatidas. Para DOMENACH, a violência é sempre humana, diferente das catástrofes naturais e da ação animal predadora, pois tem relação com a liberdade. A violência, como forma de relação entre dois sujeitos, consiste na liberdade (real ou suposta) de um que quer forçar à liberdade do outro. Coloca-se em discussão se todos os diversos tipos de violência poderiam ser moralmente condenáveis a princípio, e conclui-se que a violência é indissociável da experiência humana e que, em sua análise, devem ser necessariamente considerados os meios, as circunstâncias e os fins. Para DOMENACH, condenar todas as violências é absurdo e hipócrita. Fazer o elogio da violência, por outro lado, é criminoso.

Esta ambigüidade de sentidos atribuídos à violência, com a qual concordamos, não nos coloca, entretanto, em uma posição neutra em relação a ela. Evidentemente, neste trabalho assumimos uma postura contra a violência, ainda que não acreditemos na possibilidade de erradicá-la totalmente. É na tentativa de um empreendimento da razão contra este sofrimento que nos colocamos aqui.

Neste sentido diríamos que, se de um lado há violências, de outro, conforme AGNES HELLER (1992), com a modernidade, uma aspiração de justiça e bemestar, colocando-se o ideal de uma vida boa e justa para todos (HELLER, 1992) 
abrindo-se a possibilidade de discutirmos os diversos tipos e expressões da violência.

A "violência contra a mulher", expressão cunhada pelo movimento social feminista há cerca de trinta anos, tentou um certo enquadre teórico e prático da questão, mas tampouco teve uma definição precisa e uma teoria explicativa consensual. A teoria feminista é interdisciplinar, bebe das mais variadas fontes e congrega diversas visões do mundo, nem sempre convergentes. Além disto, o debate na área é mais recente e menos caudaloso, apesar de seu rápido crescimento nos últimos 30 anos. $\mathrm{O}$ termo diz respeito genericamente a sofrimentos e agressões que estão profundamente arraigados na vida social, e que vinham sendo percebidos como situações normais, sempre que estes sofrimentos e agressões eram dirigidos especificamente às mulheres pelo fato de serem mulheres. O que se enuncia são formas diversas de violência, com expressões variadas e particulares, que compartilham este significado social comum - a iniqüidade de gênero.

A expressão "violência contra a mulher" indica situações tão diversas como a violência física, sexual e psicológica cometida por parceiros íntimos, o estupro, o abuso sexual de meninas, o assédio sexual no local de trabalho, a violência contra a homossexualidade, o tráfico de mulheres, o turismo sexual, a violência étnica e racial, a violência cometida pelo Estado, por ação ou omissão, a mutilação genital feminina, a violência e assassinatos ligados ao dote e o estupro em massa nas guerras e conflitos armados GROSSI (1995), OEA (1996).

É fácil dizer que o estupro sistemático cometido em situações de guerras ou conflitos armados, os assassinatos pelo dote na China são formas de violência contra a mulher. Mas é difícil precisar o limite em que a violência perpassa e é perpassada pelas relações cotidianas de gênero e não se expressa na forma radical do homicídio ou das lesões graves. Qual, por exemplo, o limite entre um elogio ou a sedução e o assédio sexual, ou o limite entre brigas comuns de casal e a 
desqualificação ou desigualdade (por exemplo, na divisão de tarefas domésticas, ou nas possibilidades de contato social e diversão) em que a situação passa a ser percebida como violência? Neste sentido, difícil será diferenciar a violência da própria relação de gênero, delimitação que faremos operando uma triangulação conceitual entre gênero, violência e poder sem identificar plenamente um ao outro, mas mantendo seus pontos de contato e interconexões.

Quando a relação de gênero veiculadora de grande desigualdade de poder pode ser chamada de violência e quando não? Qual é o seu outro? O que é aquilo que lhe escapa? Como estabelecemos o limite daquilo que não é mais violência? Adiante, vamos tratar deste problema mais profundamente. Retomemos neste momento como os estudos sobre violência tem feito suas diversas conceituações.

Pesquisadores da área da sociologia, epidemiologia e criminologia para realizar pesquisas quantitativas em grandes amostras definem a violência geralmenta como atos de agressão física NATIONAL RESEARCH COUNCIL(1996). A violência física refere-se a atos de agressão bem delimitados, que são facilmente descritos e contabilizados, e que podem ser enunciados de maneira bastante objetiva. Um instrumento de medida bastante utilizado, o Conflict Tatics Scale ELLSBERG (1998) lista comportamentos como: atirar objetos, estapear, chutar, bater, ameaçar com arma, ou usar uma arma, por exemplo. O Abuse Assessment Screen NORTON (1995), proposto como screening a ser utilizado para gestantes em serviços de saúde, também discrimina detalhadamente os atos considerados como violência. A violência sexual vem sendo também definida detalhadamente por meio de atos e comportamentos específicos. O uso de definições restritas como estas é justificado por ativistas, uma vez que definições muito amplas apresentam o risco de não diferenciar a violência explícita de violações do direito humano em geral, como discriminações e pobreza, igualmente importantes, mas que já têm termos próprios para designá-los HEISE et al (1994). 
Assim, definições muito genéricas esvaziariam o problema mais agudo e grave da violência física e sexual.

Outros pesquisadores sugerem definições que comportem também a dimensão psicológica, baseados em estudos qualitativos que mostram a privação de liberdade, insultos e outros eventos, caracterizados como violência psicológica ou emocional, descritos pelas próprias mulheres como mais impactantes na sua vivência da situação do que as agressões físicas e devendo, portanto, ser considerados nas investigações, ainda que sua definição seja ainda mais difícil. A dificuldade de definição é tão grande, que o Painel sobre Pesquisa em Violência Contra a Mulher, promovido pelo NATIONAL RESEARCH COUNCIL, em 1995, nos EUA, não conseguiu chegar a uma definição consensual a respeito da inclusão ou não da violência psicológica na definição de violência contra a mulher para proceder à revisão da literatura, e trabalhou com uma definição aberta NATIONAL RESEARCH COUNCIL (1996).

A idéia de violência psicológica, entretanto, pode paradoxalmente também restringir-se ao plano individual, atomizando uma situação que é de fato relacional. A tentativa de quantificar este aspecto do problema originou diversas escalas, com itens como ataques verbais, restrição a contatos com os outros, ciúmes e possessividade extremos, ameaças verbais de agressão à pessoa e seus familiares, e destruição ou dano à propriedade da pessoa atingida (FOLLINGSTAD et al, 1990). Em nosso caso, utilizaremos para estas situações a idéia de contexto de violência, que busca englobar tanto a percepção individual da situação de violência como o seu entorno Não trabalharemos, entretanto, com os efeitos emocionais referentes a tal situação, o que seria o caso se adotássemos o recorte "violência psicológica" ou "emocional". Chamaremos de contexto de violência aqueles casos em que há outros tipos de violência percebidos pela mulher, que não se encaixam na definição estrita de violência física ou sexual, e que fazem parte do contexto de vida em que a violência mais explícita também, algumas vezes, se apresenta. 
Ainda que importantíssimos para conhecer a magnitude do problema para as mulheres e fatores a eles associados, os ataques físicos e sexuais ou sofrimentos psicológicos indicam a violência, mas não expressam necessariamente seu contexto intersubjetivo e social, e os estudos populacionais, na maioria das vezes, não expressam este contexto. Para isto, necessitaríamos de uma definição de violência que levasse em conta não apenas comportamentos ou agravos individuais, mas também as relações, privadas ou públicas entre indivíduos, e os sentidos que estas relações produzem nas ações e palavras. A compreensão dos comportamentos de agressão física, por exemplo, estaria dada não apenas pela sua caracterização e freqüência precisa, mas principalmente pelo seu sentido em uma rede social de relações para aqueles envolvidos na situação.

Se não bastassem as dificuldades de definir e explicar a violência contra a mulher e suas diversas formas de apresentação internas ao campo da teoria feminista, cabe ainda lembrar que a idéia de violência no interior de relações íntimas tem imbricações com um outro campo, com outra perspectiva do problema: os estudos da violência intra-familiar. Estestambém têm a violência nas relações de casal como um de seus objetos de estudo, com base em marcos conceituais bem diversos.

Esta interseção pode ser graficamente representada da seguinte forma: 


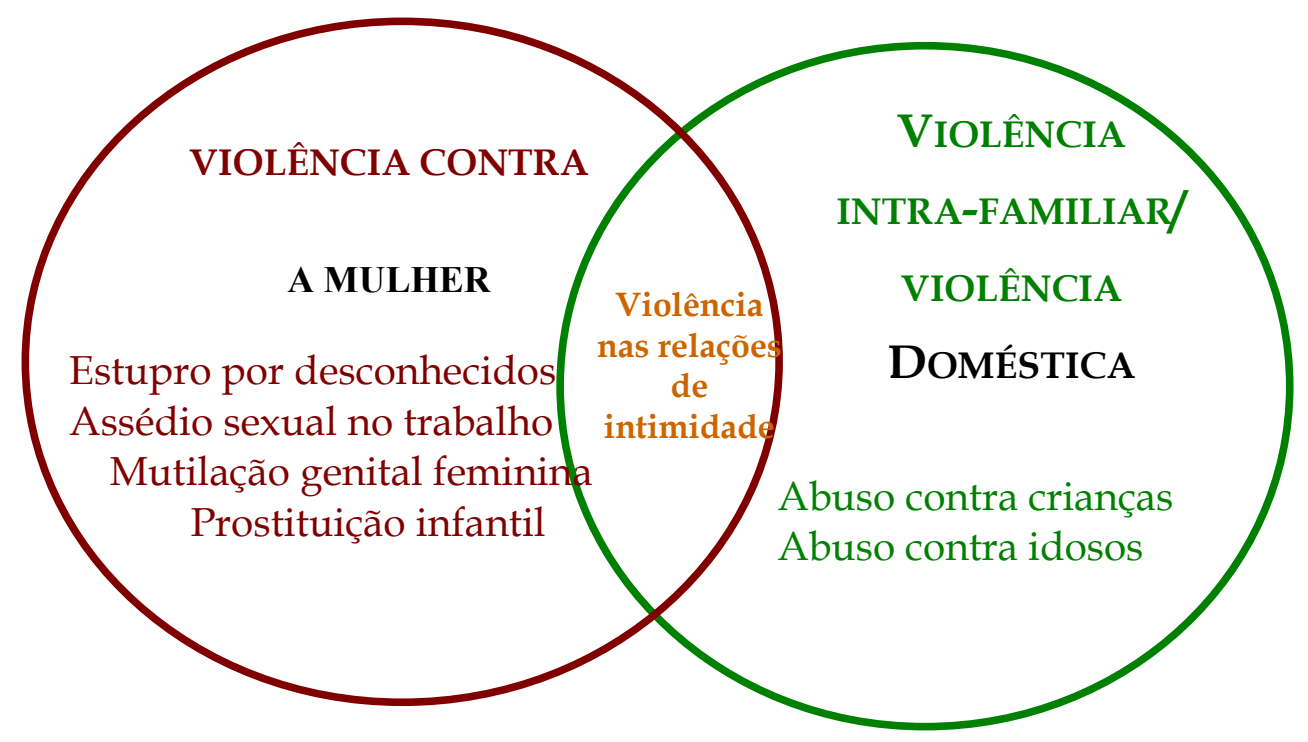

A violência nas relações amorosas e de intimidade pode ser explicada utilizando-se teorias provenientes destes dois grandes campos, e, muitas vezes, por concepções mistas entre eles.

Nem todos os pesquisadores e profissionais, portanto, aceitam a perspectiva feminista para analisar a violência no interior das relações conjugais. Aqueles que usam o termo violência intra-familiar mais comumente expressam uma visão de neutralidade em relação às diferenças de gênero, recusando a perspectiva feminista de análise (GELLES; CORNELL, 1985). Referem-se a agressões físicas, emocionais ou sexuais dirigidas a crianças, idosos, ou entre o casal, independente do sexo da vítima ou do agressor. A violência no interior da família é um problema reconhecido há muitos anos, e pelo menos desde os anos 70 há grupos de pesquisadores e profissionais, especialmente do serviço social e psicologia, envolvidos com o assunto (LYSTAD, 1986). As teorias explicativas do problema baseiam-se em uma causalidade múltipla, englobando fatores sócio-estruturais, como desemprego, más condições de trabalho e problemas de saúde, a aceitação cultural da violência pela sociedade, expressa na mídia e em pesquisas de opinião, fatores individuais e padrões culturalmente incorporados de resolução de conflitos. Nesta concepção, a questão de gênero é considerada como mais um fator 
em um conjunto amplo de causação, bastante importante para alguns deles (SWIFT, 1986). A postura feminista é criticada por outros pesquisadores desta linha e acusada de estar enviesando o conhecimento da realidade por conta de objetivos políticos, que impediriam a percepção da violência das mulheres contra os homens e até a visibilidade de eventuais "homens espancados" (GELLES; CORNELL, 1985).

Já a perspectiva feminista enfatiza a importância da diferença de poder entre homens e mulheres para explicar esta violência ocorrida entre os membros da família, sustentando que na imensa maioria das vezes os agressores são homens, e as vítimas, mulheres e crianças, e este fato deve ser considerado na definição, explicação e soluções apontadas para o problema. Para esta perspectiva, todas as formas de violência contra a mulher teriam raízes comuns nas desigualdades de gênero, e por isto as agressões físicas e sexuais cometidas por parceiros e ex-parceiros teriam a mesma base que o estupro de guerra, o tráfico sexual de meninas e outras formas de violência que ocorrem no espaço " público", devendo compor um campo de conhecimento comum. Nesta concepção, mesmo as agressões que partem das mulheres têm sua origem nesta desigualdade e seus sentidos seriam diversos da agressão masculina, e também seriam menos condenáveis, já que são interpretados como reativos à diferença de poder e à violência percebidas como injustas. Algumas autoras sugerem que a violência é sempre masculina, independentemente do sexo de quem a pratica, pois estaria determinada por esta desigualdade de poder estrutural (SAFFIOTI, 1995). Outro argumento para a importância da diferença de gênero para explicar esta violência é que as mulheres sofrem conseqüências físicas e psicológicas muito mais graves do que os homens. A perspectiva feminista argumenta que não é possível tratar todos os membros da família como se estivessem, a princípio, em igualdade de condições. Portanto, a violência cometida e sofrida por homens e mulheres teria 
significados políticos e sociais muito diversos, fato que a discussão da violência intra-familiar não estaria levando em conta (KURZ, 1997).

A nosso ver, os estudiosos da violência intra-familiar têm a vantagem de indicar para a rede de relações sociais mais ampla que determina a violência doméstica e chamar a atenção para os agravos cometidos contra crianças, idosos, portadores de deficiências e outras pessoas em situação de grande vulnerabilidade. Por outro lado, deixam de considerar, muitas vezes, todas as desigualdades estruturais desta rede, especialmente a determinada pelas relações de gênero, que o feminismo aponta, em nossa opinião, com razão.

Dentre todas as formas de violência contra a mulher, as agressões físicas de homens contra mulheres em relações amorosas têm sido especialmente trabalhadas. Só mais recentemente outras situações, como o estupro ou assédio sexual no trabalho, passaram também a ser lembradas (GROSSI, 1995). Este fato corresponde a uma constatação: as mulheres estão em maior risco de agressão física e sexual por pessoas próximas do que por desconhecidos. Esta constatação, antes de estatística, entretanto, é da prática política: essa forma de violência é uma das prioridades consistentes detectadas por ativistas em oficinas com mulheres de todas as camadas sociais e é uma das principais bandeiras do movimento feminista, o que tem incitado a produção de conhecimento científico. Sua conceituação, entretanto, tampouco é consensual.

Uma definição bastante utilizada para estas situações é o de violência doméstica. Nos Estados Unidos a palavra é usada como sinônimo de violência contra a mulher pelo seu marido ELLSBERG, (1998) STARK; FLITCRAFT, (1996). Na América Latina, o termo algumas vezes também é sinônimo de violência contra a mulher, mas diz respeito ainda a agressões sofridas por crianças, especialmente meninas (SAFFIOTI, 1995). Costuma ser dividida em violência física, psicológica e sexual (NATIONAL RESEARCH COUNCIL, 1996, AZEVEDO; GUERRA, 1989), e 
em alguns casos, também econômica (ELLSBERG, 1998). Aqueles que usam o termo violência doméstica geralmente não a identificam com o campo da violência intra-familiar, e orientam-se pelo referencial feminista.

Utilizaremos violência doméstica para referir à violência contra crianças, idosos e mulheres muito íntimos, que convivem ou conviveram no espaço doméstico, e estaremos submetendo tal situação ao olhar do referencial de gênero, ressalvando deste a perspectiva sempre relacional em que, reativa ou não, toda situação de relação na qual as mulheres participam são, elas também, construtoras das interações ali produzidas. Partícipes, muitas vezes, como sujeitos de menor poder e menor valor social, mas sempre, de algum modo, sujeitos de relações estabelecidas. A perda da condição de sujeito é o que reconheceremos como violência de gênero e não mais apenas relações de gênero, como se verá adiante, quando diferenciarmos violência nas relações de poder.

Já a idéia de violência nas relações amorosas, ou conjugal, refere-se a uma situação geralmente mais bem delimitada: o uso de força física ou do abuso emocional e o controle em relações amorosas entre adultos (STARK; FLITCRAFT, 1991). Surgido também mais recentemente, esta questão tem recebido ainda outras denominações. Abuso marital (spouse abuse) e violência entre parceiros íntimos (intimate partner violence) (SACHS, 1998) indicam situações em que os dois membros do casal podem estar envolvidos. Esta posição têm sido criticada pelas feministas por não enfatizarem ser a vítima, na maioria das vezes, uma mulher (ELLSBERG, 1998). Espancamento de esposas (wife battering), estupro marital (marital rape) e mulheres espancadas (battered women), por outro lado, indicam expressamente que a violência é cometida pelo homem contra a mulher (CAMPBELL, 1992). Os três últimos, no entanto, são acusados de ocultar o fato de que nem sempre a pessoa agredida nestas situações é uma mulher e que a violência não ocorre apenas em relações de casal formalmente constituídas, mas também pode ocorrer em relações homossexuais ou de namoro, por exemplo. 
No Brasil, o termo mulheres espancadas (battered women), muito empregado na literatura norte-americana, não parece ter "pegado" , sendo mais utilizadas as expressões violência conjugal (BRANDÃO, 1996), ou violência nas relações amorosas. Optaremos por usar estes dois últimos termos, por reconhecermos que a violência nas relações de casal não é sempre e apenas cometida pelos homens contra as mulheres, ainda que o seja com maior freqüência e gravidade, e porque o termo relações amorosas engloba bem as diversas possibilidades de arranjo de casal presentes na cultura brasileira. Quem comete a violência e quem a sofre e o tipo de violência cometido cunham sentidos diversos para a violência, sentidos esses que a violência nas relações amorosas assume, articulada às relações de poder estabelecidas entre os gêneros.

Em nosso estudo, o objeto considerado é a violência contra a mulher no sentido de violência de gênero, a qual enfeixa tanto a violência doméstica (e dentro dela a violência nas relações amorosas) como a sexual. O referencial teórico que construímos, porém, não pertence inteiramente a nenhuma destas linhas arroladas. Consideraremos, em nossa análise, a questão da desigualdade nas relações de gênero para explicar estas situações, mas entendemos que esta condição se expresse diferentemente por referência às situações de classe social e de etnia. Estas últimas perspectivas não foram privilegiadas no desenho da pesquisa, mas surgem mescladas a questões de gênero e serão levadas em conta no conceito de "contexto" em que as situações de violência se apresentam. Pobreza e/ou discriminação étnica e seus efeitos de exclusão ou marginalidade somam-se às subordinações de gênero aqui presentes e serão apenas neste sentido (de potencializador de efeitos) considerados.

Já quanto à questão intra-familiar, será reestratificada da perspectiva das relações de gênero, considerando a mulher até como possível agressora das crianças ou de idosos. Também neste caso, tal qual formulamos a propósito da violência nas relações amorosas, consideramos que a mulher é construtora das 
relações existentes. Considerar a perspectiva de gênero não está identificado, portanto, em nosso referencial, com a cristalização da mulher em uma posição subordinada e fixa na qual nunca é responsável, o que acontece em alguns estudos do problema que acabam por vitimizar a mulher.

Consideraremos também as relações com as instituições e o que vem sendo chamado de violência institucional cometida pelos serviços de saúde, entre outros (SOUZA, 1992), (CLADEM/CRP, 1998), (DINIZ, 1996), (D’OLIVEIRA, 1998). Esta forma de violência será melhor abordada quando falarmos de medicalização, mais adiante, e é bastante importante para a aproximação que estamos realizando aqui. Diz respeito, genericamente, ao desrespeito à autonomia dos usuários de serviços de saúde, sua exclusão das decisões técnicas e éticas a seu respeito e a maus tratos cometidos contra a população pelas instituições que deveriam servi-la. Se pode ser cometida "contra a mulher", esta violência não é de forma alguma exclusiva destas, ainda que as relações de gênero acabem por engendrar manifestações específicas desta violência, especialmente no que diz respeito à atenção à saúde sexual e reprodutiva feminina.

A incorporação da noção de gênero ao campo traz questionamentos importantes para o nosso problema, que serão explicitados a seguir:

\subsection{Relações de gênero e violência: da violência contra a mulher à} violência de gênero

No final dos anos 80, inicia-se a incorporação, no Brasil, do conceito de relações de gênero à pesquisa e prática política. Esta perspectiva traz promissoras possibilidades de avanço na produção de conhecimento sobre as chamadas questões da condição feminina. Todo um campo de "estudos de mulheres" se redefine para "estudos de gênero". O conceito é também apropriado no campo da violência contra a mulher. Surge, até, um novo termo para expressar a introdução 
do conceito e substituir e ampliar a idéia de "violência contra a mulher": violência de gênero (gender violence), que busca incorporar a visão relacional à compreensão do problema (O’TOOLE; SCHIFFMAN, 1997).

A incorporação da noção de gênero pode, a nosso ver, ajudar a enfrentar dois riscos no campo: o essencialismo e o vitimismo. $\mathrm{O}$ risco da essencialização e universalização consiste em se admitir algum fundamento único, imutável e absoluto, para explicar as desigualdades de poder nas relações de gênero. Assim, todas as mulheres seriam vítimas em potencial e todos os homens agressores, sem perspectivas de mediação entre norma social e existência particular e sem perspectivas de mudança. O risco do vitimismo diz respeito, correlatamente a esta visão essencialista, a conceber as mulheres como seres não responsáveis por suas próprias ações e portanto pessoas desprovidas de capacidade de ação, pensamento e juízo, que apenas introjetam a vontade alheia e a norma social sem possibilidade de reflexão e crítica.

De um modo geral, a perspectiva inicial de violência contra a mulher adotou a idéia de que, em uma sociedade onde os homens teriam mais poder, a violência seria um meio que eles utilizariam para perpetuar esta situação de desigualdade. Algumas aplicações mais mecânicas da idéia de patriarcado viam em cada mulher uma potencial vítima e em cada homem um potencial agressor, incorrendo em vitimização e essencialização da mulher, explicada agora não mais pela biologia, mas, sim, pela cultura concebida como cristalizada e imutável.

Ao fazer uma análise da retórica de importantes feministas norteamericanas acerca do estupro entre os anos de 1971 e 1985, BURTON (1998) defende que o discurso vitimizador da mulher pode ter se transformado de arma em obstáculo na luta contra a violência. Se já foi importante em determinado momento, agora este discurso parece perigoso, por definir toda a mulher como potencial vítima de agressão sexual e incapaz de reação ou defesa, não oferecendo 
possibilidades de mudança da situação. Burton argumenta que as feministas deveriam rechaçar a idéia de vítima, ao invés de cultivá-la, e reforçar a capacidade de defesa, resistência e luta das mulheres.

A introdução da noção de gênero no campo reforça esta crítica e busca superá-la.

Talvez a forma mais fácil de explicar esta noção seja em sua contraposição a sexo. Enquanto sexo indica uma diferença anatômica/genética inscrita no corpo, gênero diz respeito à construção social, material e simbólica com base nesta diferença, que transforma de distintas maneiras bebês em homens e mulheres, em cada época e lugar. A idéia é antiga. Simone de Beauvoir já dizia, desde os anos 50, que as diferenças sexuais são historicamente construídas (BEAUVOIR, 1970). O que tem um surpreendente avanço nos anos 80 e 90 é o refinamento e complexificação desta idéia e uma ampliação de seu uso nos mais diversos campos de estudo, tais como história, antropologia, sociologia, psicologia, direito, crítica literária, psicanálise, educação, saúde e economia, entre outros, e o início, nos anos 90, de pesquisas também sobre a masculinidade.

Em um dos textos mais conhecidos (SCOTT, 1995), gênero é essencialmente definido como:

O núcleo essencial da definição baseia-se na conexão integral entre duas proposições: o gênero é um elemento constitutivo de relações sociais baseado nas diferenças percebidas entre os sexos, e o gênero é uma forma primeira de significar as relações de poder (SCOTT, 1995:14).

Esta perspectiva implica em que o masculino e o feminino são construções sociais importantes nas definições das relações de poder.

Se gênero refere-se a relações de poder constitutivas das relações sociais, então cada época e lugar apresenta eixos de poder próprios, que se cruzam com os eixos de poder relativos à etnia, classe social e geração, e cada indivíduo reatualiza 
estas relações de infinitas maneiras, a partir de uma base material e simbólica dada por seu corpo e sua inserção no mundo. Como diz BUTLER (1987), gênero é uma forma ativa de viver o corpo no mundo. Existem, portanto, dentro de um limite histórico, inúmeras formas de "viver o corpo" no mundo, que reconstroem de forma imprevisível o masculino e o feminino todos os dias com base na tradição herdada, transformando e reafirmando esta tradição. Adotaremos esta perspectiva, porque nos permite compreender as relações de gênero e as demais relações sociais não como uma reprodução mecânica de estruturas ou ideologias determinadas, mas como atualizações constantes e até certo ponto imprevisíveis destas estruturas, porque vividas por seres humanos.

No Brasil, uma postura fundadora, que hoje já é clássica no campo da violência de gênero, está colocada em um texto de Marilena Chauí, intitulado "Contribuição ao debate da violência contra a mulher". Neste artigo, de 1984, Chauí argumenta que, em nossa sociedade, a mulher é constituída como sujeito heteronomamente, e, portanto, não com os outros, mas para e pelos outros. Por isto, ela seria não só submetida à violência, mas também sua autora, ao subordinar outras mulheres a esta mesma condição.

A autora começa por definir força:

Entenderemos por força, portanto, as relações de exploração econômica, de dominação política, de exclusão cultural, de sujeição ideológica e de coação física e psíquica." (CHAUÍ, 1984: 84).

Violência é para esta autora uma realização particular de relação de força, porque a pura relação de força visa, em última instância, a aniquilação de uma das partes e o fim da relação.

A violência, pelo contrário, visa a manter a relação mantendo as partes presentes uma para a outra, porém uma delas anulada em sua diferença e submetida à ação da outra. A força deseja a morte ou a supressão imediata do outro. A violência deseja a sujeição consentida ou a supressão mediatizada pela vontade do 
outro que consente em ser suprimido em sua diferença (CHAUÍ, 1984: 35).

Para ela, a violência se define por dois aspectos: em primeiro lugar, a conversão de uma diferença ou assimetria numa relação hierárquica e de desigualdade com fins de dominação e, em segundo, a ação que trata o ser humano não como sujeito, mas como objeto. A violência perfeita, para ela, é aquela em que "o sujeito consente em ser suprimido em sua diferença, assumindo como sua a vontade e a ação do outro, e submerso em uma heteronomia que não é percebida como tal".

Esta conceituação está baseada na concepção de liberdade colocada por Chauí, extraída de Spinoza:

"a liberdade não é, pois, a escolha voluntária ante várias opções, mas a capacidade de autodeterminação para pensar, querer, sentir e agir. É autonomia.(...) Nessa perspectiva, ser sujeito é construir-se e constituir-se como capaz de autonomia numa relação tal que as coisas e os demais não se ofereçam como determinadores do que somos e fazemos, mas como o campo no qual o que somos e fazemos pode ter a capacidade aumentada ou diminuída, segundo nos submetamos ou não à força e à violência ou sejamos agentes delas".

Outra importante autora, Gregori, argumenta que uma boa parte das pesquisadoras do campo da violência conjugal trabalham com generalizações, construindo para todos os casamentos violentos um conjunto de gestos, expectativas e padrões morais por parte dos agentes: “Os homens humilham $e$ agridem, as mulheres sentem medo, vergonha e se sentem culpadas. Os homens agem, as mulheres sentem." (GREGORI, 1992) A autora lembra que estas concepções generalizadoras e dualistas da violência têm limitações científicas e políticas. A passagem direta e mecânica do plano da ideologia para a ação dos agentes não permite compreender a ambigüidade da violência e as formas peculiares como as 
relações de gênero, classe e etnia se atualizam de forma contraditória em cada interação humana. Concordamos com Gregori sobre a percepção das ambigüidades traduzidas em cada imprevisível atualização da ideologia em situações concretas, realizada com diferentes mediações, que nos traz um quadro interpretativo mais amplo e capaz de explicar também a violência das mulheres contra os homens e das mulheres entre elas mesmas, além de acrescentar detalhes e relevo a complexidade de cada situação de violência, evitando os estereótipos e as aplicações mecânica de determinações mais gerais.

Apesar de reconhecer no texto de Chauí uma posição mais sofisticada, pois a mulher é vista como um sujeito dependente, mas não por isso passiva, Gregori, assim como, de outra perspectiva, SAFFIOTI (1995), acusam a autora de não oferecer alternativas de mudança para que a mulher se liberte. Alegam que, imersa na heteronomia, a mulher assumiria sempre como sua a vontade do outro, e não poderia assim criticar sua própria submissão. Como efetivamente esta crítica vem ocorrendo, como poderia esta "subversão" ser explicada? Parece-nos que, conforme ainda CHAUí (1983), a sujeição ideológica não significa perda total e permanente da condição de sujeito, senão situação transitória e parcial. A introjeção do discurso da ideologia realizada pelo sujeito não extermina a possibilidade crítica, já que as lacunas características deste discurso dão margem a reapropriações e vivências particulares e possibilidades críticas.

Assumiremos aqui que as mulheres são sujeitos, submetidas a certas alienações e capazes de transcendê-las pela vivência das próprias contradições entre o cunhado pela ideologia e o experienciado na vida vivida nas interações com os outros. É claro que também é de Chauí a idéia de que confrontada com a realidade prática, a ideologia se refaz, mas sempre e de novo como situação, isto é, realidade relacional. 
Isto não significa negar as desigualdades de gênero e a posição desprivilegiada da maioria das mulheres. Implica apenas considerá-las sujeitos “em situação" (HELLER, 1986), capazes de pensamento e ações eticamente orientados. Adotaremos esta perspectiva em nossa análise e, coerentemente, utilizaremos o termo "mulheres em situação de violência", em substituição a "mulheres vítimas de violência", seguindo tendência iniciada por serviços de assistência à violência em São Paulo, no final dos anos 80, e ampliada para todo o país ${ }^{1}$, para ressaltar justamente a postura não vitimista ou essencialista que buscamos aqui.

Vale destacar, neste sentido, a atual vertente de estudos que, por valorizar mais a dimensão relacional de gênero do que a do indivíduo mulher em separado, vem pesquisando o outro sujeito em relação: os homens.

Tem-se iniciado uma coerente e promissora tendência de aumento das análises da violência cometida pelos e contra os homens desta perspectiva. Já há algum acúmulo de conhecimento sobre as causas dos comportamentos agressivos, e algumas avaliações de propostas de intervenção dirigidas aos homens agressores (TIFFT, 1993). Diversas características relacionadas aos agressores parecem ser mais importantes para a explicação da violência conjugal do que características associadas às vítimas (ELLSBERG, 1998). Esta introdução dos homens como objeto de estudo e intervenção não se deu sem resistências: parcelas importantes do movimento de mulheres não consideram prioridade gastar verbas e trabalho com os homens, quando ainda há tanto a fazer em relação às mulheres. Esta posição, embora compreensível, não leva em consideração nem o interesse das mulheres em situação de violência, que muitas vezes, assim como mostramos no caso das DDMs, solicitam intervenções para melhorar sua situação de vida com seus

1 É interessante notar que foi um serviço de assistência às "vítimas de violência" (Casa Eliane de Grammont, PMSP) que propôs pela primeira vez esta mudança, incomodado com a vitimização. Isto nos reforça a idéia de que, se pode ter tido sucessos na ação política, a vitimização é contraproducente no trabalho assistencial com este tipo de situação. 
maridos, nem a necessidade ética de empreender um movimento contra a violência em geral. Esta, a nosso ver, é fundamental na colocação e compreensão do problema, assim como na sua intervenção, já que estamos falando da qualidade das relações humanas, do ponto de vista da emancipação de homens e mulheres nas relações de gênero.

Da perspectiva da produção de conhecimento, o foco também no masculino pode contribuir para explicar melhor as situações de violência, aprofundando as questões de poder, masculinidade e autoridade. Da perspectiva política, a utopia que perseguimos deverá sempre ser uma visão que se importe com todos os outros seres humanos, e, portanto, é uma tarefa para homens e mulheres de todos os tipos, cores e preferências.

Uma importante distinção conceitual a ser feita a este respeito é entre a emancipação de homens e mulheres, como discutimos, e o empoderamento das mulheres, noção extremamente em voga para referir a perda relativa de poder das mulheres nas relações de gênero. Não iremos trabalhar diretamente com tais noções na análise do material empírico, mas é oportuno considerar, em conformidade com os referenciais adotados, que a questão emancipatória precede, do ponto de vista ético, o empoderamento, assim como representa uma conceituação mais abstrata e geral do que o empoderamento de indivíduos em contextos particulares pode representar movimentos iniciais e parciais. A emancipação é percebida aqui como o norte ético das relações interativas na modalidade $\mathrm{Eu}-\mathrm{Tu}$, em recusa à coisificação de qualquer sujeito em relação ao outro na relação Eu-Isso, conforma BUBBER (s/data). No interior desta dinâmica emancipação-empoderamento, veremos crescer de importância a discussão da violência como violação dos direitos humanos. 


\subsection{Violência de gênero como violação dos direitos humanos: os}

direitos humanos das mulheres

No final da década de 80, a maioria dos países já tinha um movimento feminista organizado nacionalmente. Já estavam também consolidadas políticas públicas governamentais e não governamentais dirigidas à demandas advindas da violência contra a mulher, especialmente políticas voltadas à assistência e abrigo das vítimas, reformas legais e no sistema policial. Esta estratégia, entretanto, estava se esgotando. As críticas à qualidade conseguida no interior do sistema policial e jurídico, autoritário e não permeável às idéias feministas, ainda que diferentes em cada país (no Brasil, a crítica à eficácia das DDMs, já apresentada, foi a principal) eram gerais, e o movimento passou a repensar sua estratégia e iniciar uma articulação com novas metas e focos.

Durante os anos 90, a discussão da violência contra a mulher foi remetida estratégica e conscientemente para três campos principais: os direitos humanos, a saúde e o desenvolvimento social. A formulação dos direitos das mulheres como direitos humanos é dos anos 90, ainda que a reivindicação de políticas públicas nas esferas jurídicas e policial estivesse sendo importante desde a década de 80 . O movimento buscou associar a violência a estas questões já tidas como mundialmente importantes, utilizando este prestígio para colocar o problema na agenda internacional. Além disto, estes campos tinham conceitos e ferramentas que poderiam ser úteis no trabalho com a violência contra a mulher, tal como resumido por HEISE, 1996, no seguinte quadro: 


\begin{tabular}{l|l}
\hline Direitos Humanos & Saúde pública \\
\hline Conceitos: & Conceitos: \\
Poder persuasivo da linguagem dos direitos & Foco na prevenção \\
Apelo à "integridade corporal" e "segurança & Análise social da saúde \\
da pessoa" & Interdisciplinaridade \\
Instrumentos: & Instrumentos: \\
Leis e convenções internacionais & Epidemiologia \\
Maquinaria dos direitos humanos & Oportunidade de intervenção precoce \\
Busca de casos e documentação & Pesquisa em ciências sociais \\
Acesso a sanções & Acesso a serviços de saúde \\
Experiência com campanhas internacionais & Experiência em mudanças \\
& comportamento
\end{tabular}

No campo feminista, estas idéias vêm sendo utilizadas como uma estratégia prioritária na luta política por agenciamento de recursos e ações dos Estados no sentido do combate à violência.

Diversas conferências governamentais das Nações Unidas, acompanhadas dos Fóruns paralelos das ONGs desde a SEGUNDA CONFERÊNCIA MUNDIAL DE DIREITOS HUMANOS-VIENA, 1993; CONFERÊNCIA MUNDIAL SOBRE POPULAÇÃO E DESENVOLVIMENTO, CAIRO, 1994; CONFERÊNCIA MUNDIAL DA MULHER, BEIJING, 1995; CONVENÇÃO INTERAMERICANA 
PARA PREVENIR, PUNIR E ERRADICAR A VIOLÊNCIA CONTRA A MULHERCONVENÇÃO DE BELÉM DO PARÁ (1994), têm reconhecido os direitos humanos das mulheres como parte integrante dos direitos universais da humanidade, afirmando o direito à igualdade política, ao exercício dos direitos reprodutivos e a uma vida livre de violência. Estes direitos são abrangentes, por abarcar todos os aspectos da violência, e universais, ao buscar um critério transcultural, assumido por diversos países ao redor do mundo. Também é um instrumento importantíssimo de pressão, já que a efetivação da "letra morta" dos tratados internacionais depende de ações concretas de ativistas, gerentes e profissionais de serviços governamentais e não governamentais ao redor do mundo, para influenciar as prioridades de agências financiadoras internacionais, mudar as legislações, realizar campanhas, abrir serviços, enfim, garantir os direitos na prática.

Além de definir o que venha a ser a violência contra a mulher, a Convenção de Belém do Pará estabelece os direitos necessários a uma vida sem violência para as mulheres,

Artigo 6

$O$ direito de toda a mulher a ser livre de violência abrange, entre outros:

a) o direito da mulher a ser livre de todas as formas de discriminação; $e$

b) o direito da mulher a ser valorizada e educada livre de padrões estereotipados de comportamento e praticas sociais $e$ culturais baseadas em conceitos de inferioridade e subordinação. (OEA, 1996),

e propõe ações para os países para a erradicação do problema.

Note-se que, para esta concepção de direitos, a condição para uma vida livre de violência é o fim da desigualdade nas relações entre homens e mulheres.

No entanto, se é do movimento emancipatório que se pretende tratar, é a pauta de empoderamentos que a crítica feminista coloca em tela. 
O conceito liberal de direitos humanos, base para esta luta política, tem sido argüido por CORREA E PETCHEVSKI, (1994), como segue:

1. O valor e o sentido dos direitos varia de acordo com o contexto político e social. Até o mais conservador e atrasado dos países tem suas próprias noções de direitos e deveres que acabam por legitimar privilégios e desigualdades,

2. A linguagem dos direitos é indeterminada: se as mulheres solicitam direitos reprodutivos e sexuais, os pais, os próprios fetos, ou os médicos e a indústria de equipamentos médicos e farmacêuticas também têm o direito de solicitar os seus próprios direitos, e

3. A linguagem de direitos humanos é abstrata, individual e universal. Em um modelo de indivíduos iguais batalhando a satisfação de seus direitos individuais, as desigualdades sociais não podem ser percebidas.

HEISE (1996) coloca um outro fator limitante, que é origem das instituições defensoras dos direitos humanos, muito ligada aos abusos perpetrados pelo Estado. Assim, abusos ocorridos em esfera privada até recentemente não eram reconhecidos como violações de direitos humanos. A autora afirma que o movimento pelos direitos humanos no ocidente tendeu a priorizar os direitos civis e políticos, em detrimento dos direitos econômicos, sociais e culturais. Assim, o movimento dos direitos humanos tem muita tradição para lidar com a defesa do cidadão contra os abusos do Estado, mas menos para lidar com a importância do Estado para a possibilidade de vivência da cidadania plena .

O movimento de mulheres, internacionalmente constituído, vem tentando trabalhar criticamente com o conceito, acreditando na construção social e histórica destas idéias e lutando para transformá-lo em um sentido mais apropriado às demandas feministas CORREA; PETCHESKY(1994). 
Também faz parte desta pauta a reivindicação para os países do terceiro mundo, da presença do Estado que deve, além de proteger o cidadão de intromissões indevidas em seus direitos individuais, garantir o plano social dos Direitos através de políticas públicas mais redistributivas e desenvolvimentistas do social necessárias para o seu exercício.

O setor mais crítico do movimento ressalta que as escolhas em termos de sexualidade e reprodução, por exemplo, nunca são apenas individuais. Feitas num contexto relacional, as escolhas sempre implicam apoios, oposições, disputas, tensões com outras pessoas próximas e importantes para a mulher, e as possibilidades de escolha estão dadas pelas condições econômicas, sociais e culturais. Pode-se falar em escolha livre e individual neste contexto? Ou melhor, o que significa uma escolha livre? Para que os direitos sejam realizados, é necessário, portanto, que sejam garantidas as condições mais gerais para sua implantação, que são públicas, e não apenas as condições individuais de "livre" escolha (CORREA; PETCHESKY, 1994).

Em suma, na linha direitos humanos, o olhar de gênero tematiza muito mais a violência como parte das questões de uma agenda política de Estado do que a ética das relações interindividuais na vida privada. Na saúde, especificamente, a questão dos Direitos Humanos converge com a perspectiva de tomar a violência não só como problema das práticas assistenciais, mas também como alvo de políticas públicas em saúde e, neste sentido, no Brasil, também como questão do PAISM. A violência contra a mulher e também a de natureza doméstica é remetida nestas circunstâncias, não só para a atuação dos profissionais em sua prática assistencial cotidiana, mas também para toda a Saúde Pública.

A perspectiva dos direitos humanos reforça especialmente, portanto, as condições econômicas, sociais e culturais para o exercício livre dos direitos, a serem garantidas pelo Estado. No caso da violência, entretanto, é pouco 
tematizado o cuidado com a intromissão do Estado na vida privada das mulheres, homens e crianças, questão importante na discussão dos direitos reprodutivos. Enquanto há muito tempo se discute a não intromissão dos interesses do Estado na regulação da fertilidade, o cuidado com a intromissão nas relações privadas não é pensado, já que a sua presença seria necessária para a proteção das mulheres e crianças neste espaço.

Podemos pensar, entretanto, que se no plano dos direitos a participação do Estado é fundamental, no plano da qualidade das interações humanas esta presença não pode recolocar-se automaticamente. A possibilidade de relações recíprocas e satisfatórias está colocada em outro campo, ainda que dependa obviamente também da garantia de direitos sociais, políticos, culturais e econômicos, como bem o demonstra a discussão em torno da necessidade destes direitos para a garantia da livre escolha sobre ter ou não filhos para cada mulher e cada casal. Este campo é a vida privada e a possibilidade de diálogo, afeto e construção conjunta de todos, e não apenas a luta política de interesses contraditórios. Nesta esfera privada, os interesses de Estado devem abrir espaço para uma outra importante dimensão da vida: a privacidade das relações interpessoais e sua singularidade e diversidade, livres de qualquer forma de regulação e protegida da violência.

O que se quer dizer aqui é, pois, que a proteção de relações interpessoais relativamente à violência não se esgota em, ainda que possa partir de, uma enunciação geral de direitos pelo Estado, como também não se esgota em providências que o Estado possa tomar na concretização de enunciados legais em programas ou políticas de assistência. É claro que esse é um problema central na relação indivíduo - Estado, quando o tema é violência doméstica. No entanto, não valerá aqui tal desenvolvimento, senão apenas apontá-lo como questão em aberto, mesmo quando há leis e DDMs ou quando há políticas de saúde protetoras da mulher e sua saúde. 


\section{Violência e Saúde da Mulher}

Violência em geral torna-se um problema para a saúde pública a partir da década de 60 (MINAYO, 1999). A primeira área da medicina a trabalhar com a questão organizadamente foi a pediatria, que passa a estudar, diagnosticar e intervir sobre o que foi chamado de síndrome do bebê espancado. A partir daí são criados, a princípio nos países centrais, programas nacionais de prevenção primária e secundária e políticas assistenciais, como centrais telefônicas voltadas para a assistência e controle do problema da violência contra crianças e adolescentes. Minayo cita o movimento feminista como também tendo "contaminado" o campo da saúde com seus conceitos e práticas de ação política no campo da saúde e da violência. Nos anos 70 e 80, a produção maior no campo da violência e saúde é dos epidemiologistas e psiquiatras, que estudam o problema do ponto de vista das tendências epidemiológicas de mortalidade, por um lado, e como questão individual e subjetiva, por outro. A partir dos anos 80, a autora identifica a entrada do tema na agenda de debates e no campo programático em saúde com mais vigor, tendendo a consolidar-se no Brasil no final dos anos 90, não sem muita controvérsia e oposição.

Na década de 90, iniciam-se parcerias entre universidades, institutos de pesquisa e serviços que desenham estratégias específicas para a prevenção e assistência de casos de violência, criando os primeiros e incipientes programas de atenção. Encerramos a década com a criação de Comitês Técnico Científicos pelo Ministério de Saúde do Brasil, através da Secretaria de Políticas de Saúde, para tratar de uma política nacional para Acidentes e Violências, do qual faz parte a Câmara específica sobre a violência contra a mulher (MS, 1999).

Remeter a questão da violência para o campo de saúde encerra vantagens e riscos. As vantagens, algumas já percebidas pelo movimento de mulheres e expostas no quadro mostrado anteriormente, dizem respeito às habilidades 
contidas na área de saúde pública, que tem tradição em trabalhar com a prevenção, detecção precoce e mudança de comportamentos. As desvantagens são o risco de medicalização da violência, reduzindo a situação a uma possível patologia ou fator de risco, a não conexão com outros suportes sociais necessários e a banalização da violência. Esta questão será melhor abordada mais adiante. Devemos lembrar aqui apenas que, se a violência pode ser também um problema para a saúde, ela não é, a nosso ver, de forma alguma uma questão exclusiva da saúde. $O$ trabalho com este tema deve ser necessariamente intersetorial, abrangendo as áreas de segurança pública, justiça, educação, cultura, comunicação social e outras que se fizerem necessárias para uma abordagem global do problema. Articular todas estas áreas está entre os grandes desafios contemporâneos do campo.

Para poder ser incorporada pela Saúde Pública, a violência, problema social por excelência, é traduzida pela epidemiologia através do item das causas de morte denominado causas externas, que engloba homicídios, suicídios, acidentes de trânsito, afogamentos e outras causas de morte intencionais ou acidentais. Analisado deste ponto de vista, o problema tem diferenças importantes entre homens e mulheres.

A mortalidade por homicídios no Brasil é preferencialmente masculina, sendo que em 1988 tinha-se 11 homens para cada mulher vítima de homicídio (Souza; Minayo, 1995). As mortes por causas externas são a segunda causa de morte para o sexo masculino e a quinta para o sexo feminino no país (SOUZA; MINAYO, 1995).

Em relação à morbidade, inquérito realizado acerca de criminalização e justiça no Brasil, em 1988, pode ser analisado aqui com ressalvas, já que pesquisas sobre criminalidade tendem a subestimar a agressão por pessoas próximas. De qualquer forma, se as agressões físicas são maiores entre os homens, o são em muito menor proporção $(60,9 \%$ das vítimas de violência física são homens) e o 
padrão do agressor é diverso: o risco de sofrerem violência por pessoas conhecidas e íntimas é bem maior para as mulheres que para os homens. Enquanto $48 \%$ das ocorrências de violência física entre as mulheres aconteceram no interior do domicílio, o mesmo aconteceu com apenas 18\% dos homens que relataram agressões. As mulheres respondem por 63\% daqueles agredidos no espaço doméstico, portanto, a maioria (FIBGE, 1990). Os dados das DELEGACIAS DE DEFESA DA MULHER, apesar do viés evidente de corresponderem apenas aos crimes denunciados neste tipo de serviço, apresentam o mesmo padrão centrado na violência doméstica, sendo o parceiro ou ex-parceiro o agressor em aproximadamente 70\% das denúncias (GOLDEMBERG, 1989).

Se olharmos para outros países, este padrão se repete. Dados do FBI de 1993 demonstram que 1531 (31\%) das 4869 mulheres vítimas de homicídios foram mortas por seus maridos, ex-maridos ou namorados, enquanto entre os 17457 homens vítimas de homicídio, 591 (3\%) foram mortos por suas esposas, ex-esposas ou namoradas NATIONAL RESEARCH COUNCIL(1996: 25).

Em outra pesquisa feita nos Estados Unidos PELO CENTER FOR DISEASE CONTROL (CDC) e PELO NATIONAL INSTITUTE OF JUSTICE (NIJ) com 8.000 homens e 8.000 mulheres, das 2.669 mulheres que declararam agressão física ou violência sexual na vida adulta, $76 \%$ haviam sido agredidas por um companheiro ou namorado (intimate partner), enquanto dos 3.606 homens que relataram o mesmo tipo de violência, apenas 17,9\% indicavam a companheira ou namorada como autora da agressão (NIJ/CDC, 1998). Entre as mulheres, 7,7\% declararam haver sido estupradas por um parceiro íntimo alguma vez na vida, enquanto entre os homens $0,3 \%$ declararam o mesmo. Quanto a agressões físicas, 22,1\% das mulheres e 7,4\% dos homens relataram algum episódio cometido por um parceiro íntimo durante a vida. 
Estas diferenças nos números traduzem modos de vida diversos entre homens e mulheres, que se manifestam em sua vulnerabilidade à violência. Os homens, especialmente os homens jovens, estão muito mais expostos que as mulheres à violência e ao homicídio cometida por estranhos ou conhecidos no espaço público. Já as mulheres estão mais sujeitas a ser agredidas por pessoas próximas e íntimas do que por desconhecidos, em situações crônicas e repetitivas. Se, ao analisarmos os homens, a grande questão da violência para a saúde pública são os homicídios por arma de fogo, ao enfocarmos as mulheres, o problema principal parece estar na morbidade e mortalidade provocada por pessoas íntimas. Esta convivência contínua com a violência é muito freqüente e está associada a diversos problemas de saúde física e mental, como veremos a seguir. A constatação é chocante, porque estamos acostumados a associar a violência e o perigo com o espaço público, a rua. Entretanto, para mulheres e crianças, ainda hoje mais restritos ao espaço privado, o maior risco parece estar no próprio lar e nas relações com pessoas próximas.

Vejamos com mais detalhes a magnitude do problema. Os estudos existentes sobre a extensão do problema centram sua definição na violência física e sexual, pela facilidade já apontada deste critério em grandes amostras.

Além da questão de dificuldades na definição, outros problemas metodológicos afetam a comparabilidade dos estudos e são também responsáveis pela disparidade dos números encontrados, como, por exemplo, as características da amostra, a formulação das questões, as condições da entrevista ou autoaplicação de questionários, o tipo de pesquisa pelo qual a informação é coletada e as questões de sigilo e segurança (ELLSBERG; HEISE, 1999).

Apesar de todas estas diferenças, os dados reunidos demonstram largamente a importância do problema. A porcentagem de mulheres que sofreram pelo menos um episódio de violência sexual na vida tem sido estimada 
internacionalmente entre $2 \%$ e 50\%, a maioria das estimativas ficando entre 13 a 25\% das mulheres, conforme o NATIONAL RESEARCH COUNCIL (1996) dos estados Unidos. Discrepâncias similares são encontradas acerca do número de incidência de violência conjugal: estudos americanos de base populacional encontraram entre $0,76 \%$ até $11,6 \%$ de mulheres vivendo esta situação no último ano (NATIONAL RESEARCH COUNCIL, 1996). Mas estes dados não são uma especificidade dos Estados Unidos: as estatísticas a seguir dão uma noção da prevalência disseminada do problema da violência conjugal ao redor do mundo, tanto em países centrais como em países periféricos:

\begin{tabular}{|c|c|c|c|}
\hline País e autor & Amostra & Tipo de amostra & Achados \\
\hline $\begin{array}{c}\text { Bélgica } \\
\text { Bruynooghe et al, } \\
1989\end{array}$ & 956 mulheres de 30 a 40 anos & $\begin{array}{l}\text { Amostra aleatória } \\
\text { de } 62 \text { municípios de } \\
\text { todo o país }\end{array}$ & $\begin{array}{l}3 \% \text { violência muito grave, } 13 \% \text { violência moderadamente } \\
\text { grave e } 25 \% \text { violência menos grave }\end{array}$ \\
\hline $\begin{array}{c}\text { Canadá } \\
\text { (Statistics Canada, } \\
1993)\end{array}$ & $\begin{array}{c}\text { Mostra representativa nacional } \\
\text { de } 12300 \text { mulheres de } 18 \text { anos } \\
\text { ou mais }\end{array}$ & $\begin{array}{l}\text { Amostra nacional } \\
\text { representativa }\end{array}$ & $\begin{array}{c}25 \% \text { das mulheres ( } 29 \% \text { das que alguma vez foram } \\
\text { casadas) informam haver sido atacadas fisicamente por } \\
\text { um companheiro atual ou anterior desde os } 16 \text { anos de } \\
\text { idade. }\end{array}$ \\
\hline EUA, 1986 & 6002 domicílios & $\begin{array}{l}\text { Mostra } \\
\text { representativa } \\
\text { nacional }\end{array}$ & $\begin{array}{l}\text { Violência física no último ano relatada por } 11,6 \% \text { das } \\
\text { mulheres; violência física severa no último ano, relatada } \\
\text { por } 3,4 \%\end{array}$ \\
\hline $\begin{array}{c}\text { Chile } \\
\text { Larrain, } 1993\end{array}$ & $\begin{array}{c}1000 \text { mulheres entre } 22 \text { e } 55 \\
\text { anos em Santiago envolvidas } \\
\text { em uma relação por } 2 \text { ou mais } \\
\text { anos }\end{array}$ & $\begin{array}{l}\text { Mostra aleatória } \\
\text { estratificada }\end{array}$ & $\begin{array}{l}60 \% \text { foram abusadas por um companheiro, } 26,2 \% \text { foram } \\
\text { fisicamente abusadas }\end{array}$ \\
\hline $\begin{array}{l}\text { Colômbia, } \\
\text { PROFAMILIA, } \\
1990\end{array}$ & $\begin{array}{l}3272 \text { mulheres urbanas } \\
2118 \text { mulheres rurais }\end{array}$ & $\begin{array}{l}\text { Amostra nacional } \\
\text { representativa }\end{array}$ & $\begin{array}{c}20 \% \text { abusadas fisicamente, } \\
\text { marido } \\
\text { mabusadas psicologicamente, } 10 \% \text { estupradas pelo } \\
\text { marido }\end{array}$ \\
\hline $\begin{array}{c}\text { México } \\
\text { Rodriguez; } \\
\text { Becerra, } 1997\end{array}$ & $\begin{array}{l}650 \text { mulheres alguma vez } \\
\text { casadas/unidas }\end{array}$ & $\begin{array}{c}\text { Mostra } \\
\text { representativa de } \\
\text { Guadalajara- região } \\
\text { metropolitana } \\
\end{array}$ & $\begin{array}{l}30 \% \text { pelo menos um episódio de violência física pelo } \\
\text { parceiro; } 13 \% \text { violência física no último ano }\end{array}$ \\
\hline $\begin{array}{c}\text { Barbados } \\
\text { Handwerker, } 1993\end{array}$ & $\begin{array}{l}264 \text { mulheres de } 20-45 \text { anos } \\
243 \text { homens de idade } 20-45\end{array}$ & $\begin{array}{c}\text { Mostra de } \\
\text { probabilidade } \\
\text { nacional de toda a } \\
\text { ilha }\end{array}$ & $30 \%$ das mulheres agredidas fisicamente como adultas \\
\hline $\begin{array}{c}\text { Índia } \\
\text { Narayana, } 1996\end{array}$ & $\begin{array}{l}6902 \text { homens casados entre } 15 \text { e } \\
65 \text { anos }\end{array}$ & $\begin{array}{l}\text { Mostra multi-etapas } \\
\text { em } 5 \text { distritos de } \\
\text { Uttar - Pradesh }\end{array}$ & $\begin{array}{c}18-45 \% \text { dos homens atualmente casados reconhecem } \\
\text { haver abusado fisicamente de suas esposas }\end{array}$ \\
\hline $\begin{array}{c}\text { Egito } \\
\text { El-Zanaty et al, } \\
1996\end{array}$ & Mulheres alguma vez casadas & $\begin{array}{l}\text { Mostra nacional } \\
\text { representativa }\end{array}$ & $\begin{array}{l}\text { 35\% das mulheres dizem ter sido golpeadas fisicamente } \\
\text { pelo esposo alguma vez no casamento }\end{array}$ \\
\hline $\begin{array}{c}\text { Zimbabwe } \\
\text { Watts, et all, } 1997\end{array}$ & $\begin{array}{l}966 \text { mulheres maiores de } 18 \\
\text { anos }\end{array}$ & $\begin{array}{l}\text { Mostra } \\
\text { representativa da } \\
\text { província de } \\
\text { Midlands }\end{array}$ & $\begin{array}{l}32 \% \text { referem abuso físico por um familiar ou membro do } \\
\text { lar desde a idade de } 16 \text { anos }\end{array}$ \\
\hline
\end{tabular}

Adaptado de HEISE et. al (1994) e ELLSBERG, (1998) 
Considerada a relativa imprecisão ainda presente na definição de violência e nos desenho dos estudos, o que torna os números pouco comparáveis, mas pode-se concluir que as evidências apontam consistentemente para o fato de que a violência conjugal é experiência bastante comum transculturalmente.

A extensão do problema o torna muito importante para a saúde: além de potenciais desfechos fatais, ele tem uma grande morbidade associada.

O Banco Mundial, em seu informe sobre o desenvolvimento mundial de 1993, que se centrou sobre a saúde, calculou os anos de vida perdidos para homens e mulheres por distintas causas. O método, chamado DALY ( Disabilitiy Adjusted Life Year), consiste em considerar não apenas os anos perdidos por mortalidade, mas também aqueles perdidos por morbidade, que valem uma fração da mortalidade a depender da gravidade da morbidade associada. No quadro a seguir, podemos ver a importância da violência como causa de morbidade na comparação com outros problemas tradicionais da saúde pública:

\begin{tabular}{|c|c|}
\hline Condição & $\begin{array}{c}\text { Anos de vida saudável perdidos } \\
\text { ajustados por incapacidade }\end{array}$ \\
\hline Condições maternas & 29,0 \\
Sepsis & 10,0 \\
Trabalho de parto prolongado & 7,8 \\
\hline Doenças de transmissão sexual (excluindo AIDS) & $\mathbf{1 5 , 8}$ \\
\hline Inflamação pélvica & $\mathbf{1 2 , 8}$ \\
\hline Tuberculose & $\mathbf{1 0 , 9}$ \\
\hline HIV/AIDS & $\mathbf{1 0 , 6}$ \\
\hline Doenças cardiovasculares & $\mathbf{1 0 , 5}$ \\
\hline Violação e violência doméstica & $\mathbf{9 , 5}$ \\
\hline Todos os canceres & $\mathbf{9 , 0}$ \\
Mama & $\mathbf{1 , 4}$ \\
\hline Colo uterino & $\mathbf{1 , 0}$ \\
\hline Acidentes automobilísticos & $\mathbf{4 , 2}$ \\
\hline Guerra & $\mathbf{2 , 7}$ \\
\hline Malária & $\mathbf{2 , 3}$ \\
\hline
\end{tabular}

Banco Mundial, 1993, In: Ellsberg, 1998 
Ao analisar artigos indexados no Medline, base de dados internacional de publicações médicas, sob a rubrica violência doméstica e serviços de saúde da mulher, encontramos uma produção variada e crescente. Os artigos geralmente buscam a ocorrência de violência conjugal ou doméstica em mulheres usuárias de serviços de saúde, encontrando números tão ou mais elevados do que os encontrados na população geral. Existem também muitos trabalhos sobre a associação da violência doméstica com agravos à saúde, uso de serviços de diversos tipos e especialidades,e tambémsobre as possibilidades de reconhecimento e trabalho com o problema pelos profissionais de saúde (ALPERT, 1995).

Quanto à freqüência do problema nos serviços de saúde, um estudo realizado pela JOHN HOPKINS em serviços de atenção primária (MCCAULEY et al, 1995) com 1.952 mulheres usuárias, encontrou 5,5\% de relatos de violência doméstica no último ano e 21,4\% de mulheres relatando violência doméstica durante a vida adulta, enquanto 32,7\% reportava violência doméstica quando criança ou adulta.

Em serviços de emergência hospitalar americanos, pesquisa com 3.455 mulheres entrevistadas encontrou $14,4 \%$ das entrevistadas relatando abuso físico ou sexual cometido por um parceiro íntimo no último ano, e 36,9\% abuso físico ou emocional durante a vida (DEANWATER, 1998). Em face desta alta prevalência, tem-se discutido o papel dos profissionais neste tipo de serviço (MCLEER, 1987).

Entre mulheres que procuram assistência médica para o aborto, foi encontrado 39,5\% das mulheres com história passada de violência física ou sexual (GLANDER, 1998).

A prevalência de violência física e sexual durante a gravidez tem oscilado nos estudos, entre 1\% e 20,1\% (GAZMARARIAN, 1996). A revisão de treze estudos de prevalência sugere que estas diferenças sejam devidas prioritariamente a 
questões metodológicas (GAZMARARIAN, 1996). Esta análise indica que as menores prevalências são encontradas em clínicas privadas, onde profissionais que não são da área da saúde distribuem questionários auto-respondidos (SMIKLE, 1996). Prevalências maiores são encontradas em inquéritos face a face feitos por profissionais de saúde treinados para isto, mais de uma vez durante a gravidez ou durante o terceiro trimestre de gestação (MCFARLANE et al, 1992; GAZMARARIAN, 1996; GIELEN, 1994). Ao contrário do que espera o senso comum, a violência não diminui necessariamente na gestação, chegando em muitos casos a piorar em intensidade ou freqüência, o que tem levado a propostas de screening durante o pré-natal (ABBASI, 1998)..

Poucos trabalhos pesquisaram a violência doméstica ou conjugal durante o período de puerpério, mas aqueles que o fizeram encontraram índices de prevalência ainda mais altos do que durante a gestação $(25 \%$ de todas as mulheres relataram violência moderada ou severa em entrevista telefônica após 6 meses do parto) (GIELEN, 1994), sugerindo um período de alta vulnerabilidade para a mulher e a criança.

Esta alta prevalência de violência tem conseqüências para a saúde que não se resumem aos traumas óbvios das agressões físicas. Além disto, a violência conjugal e sexual tem sido associada ao risco aumentado para diversos problemas de saúde como: baixo peso ao nascer e prematuridade (MCFARLANE; et al, 1992; CAMPBELL, 1992), sintomas ginecológicos (SCHEI, 1989), doenças sexualmente transmissíveis e AIDS (HEISE et al, 1994), depressão, suicídio (STARK; FLITCRAFT, 1995), gravidez indesejada, queixas vagas (HEISE et al, 1994; STARK; FLITCRAFT, 1996), patologias gastrointestinais (DROSSMAN et al, 1995), uso de álcool e drogas (HEISE et al, 1994), entre outras.

Quanto aos fatores de risco para violência, as tentativas de procurar o equivalente a "grupos de risco" foi infrutífera até agora. Nenhum fator 
individualmente pode indicar com certeza um grupo com risco aumentado o suficiente para violência que merecesse ser indicado como alvo de políticas prioritárias, ou critério para busca ativa em serviços de saúde.

Entretanto, alguns fatores têm sido apontados como consistentemente associados à violência conjugal. As mulheres mais jovens têm as maiores possibilidades de experienciar violência, seja ela homicídios, estupro, ou violência conjugal (NATIONAL RESEARCH COUNCIL, 1996; DEARWATER, 1996). O uso de álcool e drogas e ter testemunhado episódios de violência entre membros da família na infância também têm associação com envolvimento em situações vigentes de violência doméstica, tanto para homens como para mulheres, embora a prevalência de uso de álcool e drogas seja maior entre os homens (STARK; FLITCRAFT; 1991 NATIONAL RESEARCH COUNCIL, 1996). Especialmente o uso de álcool ou drogas pelo parceiro tem se confirmado mais recentemente como um fator de risco importante (KYRIACOU ET ALL, 1999; GRISSO ET ALL, 1999). .Apesar de a violência parecer afetar todas as camadas sociais, aquelas com piores condições econômicas tendem a ter índices mais altos de violência doméstica. De outro lado, as mulheres que têm trabalhos de maior renda ou prestígio em relação ao de seus cônjuges também estão em maior risco (Stark; FLITCRAFT, 1991; DEARWATER, 1998). Mulheres solteiras, separadas e divorciadas também, especialmente aquelas em processo de separação (STARK; FLITCRAFT, 1991).

Mulheres que sofrem violência física e sexual parecem também utilizar mais os serviços de saúde do que aquelas que não estão nesta situação KOSS (1991), (SCHRAIBER; D’OLIVEIRA, 1999 a) já que são mais vulneráveis a problemas de saúde diversos. Mulheres que sofrem violência, mesmo de baixa severidade, têm mais sintomas físicos e mentais que aquelas que não têm história de violência. $\mathrm{A}$ quantidade de queixas aumenta à medida que aumenta a severidade do abuso MCCAULEY et al (1995), e este efeito persiste mesmo após o fim das situações de violência. Esta maior freqüência de queixas sem substrato anatômico faz com que 
estas pacientes sejam rotuladas nos serviços como histéricas, somatizadoras ou poliqueixosas e desqualificadas em suas queixas. Apesar da alta freqüência do problema entre mulheres usuárias, os profissionais de saúde não identificam a maioria dos casos e quase não registram a violência em prontuário como parte do atendimento STARK; FLITCRAFT (1996); SUGG; INUI (1992) RODRIGUEZ (1999).

Embora não registrem em prontuário nenhuma menção à violência doméstica e discriminem dificuldades em abordar diretamente o problema, os profissionais parecem reconhecer a situação, porque prescrevem diferenciadamente. Em um estudo americano, 24\% das mulheres em situação de violência, atendidas em um pronto socorro, receberam tranqüilizantes ou analgésicos, enquanto $9 \%$ das mulheres com lesões não intencionais obtiveram a mesma prescrição (STARK; FLITCRAFT, 1996). O mesmo estudo mostra que a situação de violência também leva a mais encaminhamentos para serviços de saúde mental: 15\% das pacientes que viviam situações de violência doméstica tiveram este tipo de encaminhamento, enquanto apenas $4 \%$ das vítimas de lesões não intencionais receberam a mesma orientação.

Estes dados vêm encorajando políticas de detecção, acolhimento e referência do problema pelos serviços de saúde. Um artigo publicado no The New England Journal of Medicine recentemente (EISENSTAT; BANCROFT, 1999), faz uma revisão da prevalência do problema e suas conseqüências para a atenção primária e propõe a incorporação da questão pelas seguintes medidas: pergunta de rotina a todas as usuárias sobre o problema; registro cuidadoso do relato e lesões observadas; respeito e consideração pela mulher, encorajando-a a utilizar os serviços de apoio disponíveis; e estabelecer com ela um plano de segurança quando necessário.

Na década de 90, diversas associações médicas, entre elas a Associação Médica Americana, publicaram protocolos de trabalho para o problema em 
serviços de saúde. Algumas propostas de intervenção vêm sendo planejadas e implantadas, com o fim de reconhecer, apreender e lidar com a questão. Para isto, existe um movimento para capacitar os profissionais de saúde para esta temática, e têm sido elaborados no mundo todo materiais locais para tal formulação (D’OLIVEIRA et al, 1995), (ELLSBERG, 1998), (AMA, 1992), (OLIVEIRA, 1999).

Estas propostas foram colocadas nos anos 90 para todos os tipos de serviços de assistência à saúde, de pronto-socorros a serviços de atenção primária, mas têm havido dificuldades em se implantar. Isto porque a adesão dos profissionais parece ser baixa. Vejamos dois estudos que buscam aprofundar estas resistências:

Um estudo etnográfico que tem sido muito citado (SUGG; INUI, 1992)., buscou justamente estudar as barreiras a esta detecção pelos profissionais médicos. O estudo realizou entrevistas abertas com 38 profissionais, predominantemente médicos de atenção primária de uma rede de serviços da Health Maintenance Organizations (HMO) em Washington, buscando as dificuldades percebidas por estes profissionais para a intervenção sobre o tema. Os médicos entrevistados trabalhavam em serviços em que a pergunta direta de rotina havia sido implantada na anamnese, e foram instados a falar da dificuldade de incorporar o tema na prática do trabalho cotidiano. Eles fazem uma ilustrativa metáfora sobre o significado de buscar ouvir o problema: para eles, trabalhar com a violência é difícil, porque é como abrir a Caixa de Pandora. Este mito, citado repetidamente pelos profissionais, refere-se a uma caixa que, assim que aberta por Pandora, liberou a doença, a insanidade, o vício e a maldade no mundo, que até então não existiam.

Pandora, figura da mitologia grega, foi criada pelos deuses como resposta ao roubo do fogo por Ptolomeu. Os deuses deram a Pandora diversas virtudes, a curiosidade e uma caixa com a recomendação expressa para não abri-la, e a enviaram à terra. Chegando aqui, Pandora não resistiu e abriu a caixa, libertando 
para sempre o mal. Mas fechou a caixa a tempo de guardar a esperança, que estava no seu fundo, para que a humanidade pudesse lidar com o seu conteúdo. O mito ilustra bem a dificuldade de abordar um tema que extrapola muito a área da saúde no interior dos serviços. Os autores levantam os principais obstáculos colocados pelos profissionais para trabalhar a questão:

1. Muito perto para confortar: quando a paciente é de uma classe e cultura próxima, os profissionais têm medo de trabalhar o problema, pois se identificam com ela: levantar este assunto seria admitir a possibilidade de seu surgimento também na própria vida do profissional, ou atentar para a presença efetiva do problema também no seu meio social;

2. Medo de ofender: os médicos têm medo da paciente não gostar que o assunto seja levantado, por não perceberem a questão como de seu âmbito de intervenção, ou por temerem estar intrometendo-se em assunto privado da mulher;

3. Impotência: já que não detêm tecnologia específica e exclusivamente médica para lidar com o problema;

4. Perda de controle: é difícil trabalhar com uma questão que os profissionais não podem resolver, já que dependem das decisões e atitudes da mulher;

5. Tirania da agenda: sensação de falta de tempo para lidar com problema complexo e que abre a "caixa de Pandora" (SUGG; INUI, 1992).

A pouca lembrança da esperança no fundo da caixa de Pandora torna ainda mais difícil vislumbrar atuações possíveis. Isto está relacionado, a nosso ver, com a tradição medicalizadora da experiência dos sofrimentos por parte da medicina: ou bem ele diz respeito ao saber biomédico e torna-se objeto da prática do médico; ou bem nada a fazer, já que o horizonte interdisciplinar e intersetorial não está presente nessa cultura profissional. 
Outra investigação deste tipo, desta vez quantitativa, foi publicada há alguns meses no Journal of American Medical Association (JAMA) (RODRIGUEZ et al, 1999). Neste trabalho, que busca o quanto os profissionais aderem às políticas de screening de rotina propostas, responderam ao questionário 400 médicos de atenção primária, assim distribuídos: 149 médicos de família, 115 internistas e 136 obstetras/ginecologistas. Encontrou-se que os médicos perguntavam ativamente acerca de violência em pacientes com lesões corporais (79\% o faziam), mas falhavam em realizar a busca ativa de rotina em todas as primeiras consultas (apenas 10\% realizavam a pergunta nestas situações). O sexo do entrevistado e o treinamento recente sobre o tema não influenciaram o padrão de respostas dos profissionais. Obstetras e ginecologistas (17\%) e médicos do serviço público (37\%) tendiam mais a fazer a pergunta para pacientes novos. Internistas (6\%) e médicos de HMO (1\%) foram os que tiveram os menores escores. As barreiras mais citadas para a identificação e referência dos casos foram: medo de retaliação por parte do paciente $(82 \%)$, medo de envolvimento com a polícia (55\%), falha do paciente em relatar o problema (78\%), falta de seguimento (52\%) e diferenças culturais (56\%). Quando um caso era descoberto, os profissionais relataram que realizavam avaliação de segurança (91\%), referência para abrigos (79\%), aconselhamento (88\%) e registro detalhado em prontuário (89\%).

Sintetizando, poderíamos construir o seguinte quadro geral: a prevalência de violência é alta, ela está associada com um uso maior de serviços de saúde, queixas e patologias, mas ela não é trabalhada pelos profissionais de saúde como relacionada a situações de violência. Muitas destas queixas podem carecer de comprovação clínica para poder ser aceitas como patologias, fazendo assim parte de um problema para a prática profissional que tem sido estudado pela psiquiatria em termos de pacientes difíceis, ou detestáveis, conforme mostra SENNA (1999). A psiquiatria tem, segundo esta autora, uma tradição de estudos destes usuários e 
das reações que provocam nos profissionais. Com suas queixas sem comprovação clínica e alto uso de serviços, os pacientes difíceis ou detestáveis são um problema, conforme a autora, especialmente para o atendimento de setores populares em atenção primária.

As propostas de intervenção existentes sobre a violência (busca ativa de casos, acolhimento, registro e referência) não têm tido grande sucesso, apesar de bem intencionadas. A nosso ver, esta dificuldade, que é uma das bases de nossas indagações no presente estudo, deve ser melhor pesquisada, sobretudo em termos de seu sentido tecnológico e produtivo como serviço da sociedade, ou seja, o que é e como poderá dizer respeito à ação em saúde, quer na esfera da Saúde Pública quer na da Assistência Individual, no tocante à apreensão e transformação do problema violência.

$\mathrm{Na}$ esfera assistencial, isto acrescenta novos dilemas ao trabalho em saúde: Qual qualidade de agravo representaria o sofrimento de mulheres em situação de violência? Que desvios da saúde isto representaria e quais processos de intervenção, como suporte da atuação em saúde, podem ser desenvolvidos no interior desta assistência?

Parece-nos que antes de introduzir perguntas de rotina na prática assistencial, como vem sendo proposto internacionalmente, é interessante conhecermos mais o que acontece atualmente na relação das mulheres em situação de violência com os serviços, para aquilatar com maior precisão o lugar e o papel específico dos serviços de saúde no interior de uma rede mais ampla de cuidado. Isto porque nos parece que a incorporação da busca ativa, que vem sendo proposta com insistência internacionalmente e que tenderá a ser incorporada em nosso país nos próximos anos pode ocasionar, sem uma reflexão mais profunda, uma desqualificação da importância do reconhecimento da questão, pela não adesão dos profissionais à proposta, tornando-a vazia. Outro risco que antevemos, nas 
atuais condições de saúde, é que profissionais bem intencionados busquem efetivar a proposta sem treino e tempo o suficiente e almejem " curar" a paciente, frustrando-se se esta não adota as medidas que consideram necessárias e desistindo do trabalho, o que desqualificaria a potencialidade da estratégia. 


\section{O desenho do estudo e o trabalho de campo}

O objetivo deste trabalho é contribuir para a compreensão da interação que se estabelece entre as usuárias e profissionais nos serviços de saúde, em torno das demandas que o problema violência contra a mulher pode originar para a produção de cuidados em saúde. Esta compreensão deve permitir conhecer as condições em que pode se dar ou obstaculizar a emergência, o acolhimento e a resposta do problema no interior de um serviço de saúde

Para isto, pesquisamos a relação estabelecida entre usuárias e profissionais, em ações do PAISM, em um centro de atenção primária, buscando as percepções, diálogos e ações acerca do problema-violência e suas conexões com a saúde. Buscamos aqui saber mais sobre os sentidos atribuídos ao uso de serviços de saúde por estas mulheres que vivem em situação de violência e a atuação profissional, e a interação estabelecida entre estes sujeitos.

Procedemos a um estudo de um determinado serviço, o CSE Samuel Pessoa (CSE), o qual foi exaustivamente explorado por uma combinação de técnicas de pesquisa. Foram elas: observação participante de grupos e atividades assistenciais individuais; estudo do registro de prontuário de todas as mulheres observadas, buscando identificar o uso do serviço em termos de quantidade e tipos de modalidade assistencial freqüentada; entrevistas abertas, com produção de narrativas do tipo depoimento pessoal (relato oral), para mulheres para as quais foram detectadas situações de violência, e entrevistas semi-estruturadas com os profissionais do serviço. Assim, compusemos perspectivas de ângulos diversos sobre a relação observada em seus vários momentos: a fala das mulheres sobre sua vida e a relação com seus problemas de saúde, a fala dos próprios profissionais sobre como lidar com o problema-violência, a interação mulheres/profissionais nas atividades assistenciais e o registro sobre os atendimentos realizados. Esta composição metodológica permite perceber a relação entre uma população de 
mulheres de um serviço com esta instituição, por meio do estudo da interação profissionais/usuárias de diversos ângulos, ampliando a compreensão e validando os achados isolados de cada técnica, ou colocando-os em questão (triangulação de técnicas).

A pesquisa de campo contou com o apoio de uma equipe multiprofissional composta por psicólogas, enfermeiras e estudantes de medicina, todos familiarizados de alguma forma com o serviço.

A equipe realizou encontros periódicos de supervisão durante todo o trabalho de campo. Esta supervisão tinha como objetivo homogeneizar a coleta e registro dos dados, enfrentar problemas ocorridos, discutir questões suscitadas pela observação direta e pela leitura da bibliografia e conferir se havia algum problema operacional de natureza infra-estrutural (fitas, pilhas, gravadores, etc...), ou da dinâmica da observação.

O trabalho de pesquisa foi desenvolvido em três etapas. Iniciou-se pela observação-participante. Foram realizadas 57 observações de atividades grupais e individuais, totalizando 142 mulheres observadas. Na segunda etapa, todas elas tiveram seus prontuários analisados. Por fim, foram entrevistadas cinco mulheres usuárias e quatro profissionais de saúde (dois médicos e duas auxiliares de enfermagem). Todas as atividades assistenciais e entrevistas foram gravadas e transcritas, além de registradas detalhadamente em caderno de campo. Os roteiros das observações e entrevistas individuais, o consentimento informado utilizado e o mapa para a análise de prontuários encontram-se anexos. Encerramos as observações de cada modalidade de atividade em função dos achados passarem a se repetir e de conseguirmos estabelecer uma possibilidade consistente de compreensão. A quantidade de material coletado, em termos de volume para processamento e densidade para a análise prevista, também contou na definição 
do número de atividades observadas. Adiante descreveremos com mais detalhes todas as técnicas utilizadas.

O caminho de lidar com a subjetividade, nossa e de nossos sujeitos pesquisados, objetivando-a em um trabalho científico que seja por isso intersubjetivamente compartilhável não nos pareceu, de forma alguma, mais simples por sua suposta "frouxidão metodológica". Ao contrário: o controle rigoroso de cada etapa do trabalho, e a dúvida sistemática nos acompanharam por todo o percurso, para garantir que seu produto fosse uma elaboração racional de cunho científico. Importam-nos os sentidos e valores expressos nas falas e acontecimentos coletados e as relações estabelecidas. Para sua interpretação contamos com o referencial teórico e o conhecimento acumulado em nossa experiência profissional.

As situações de violência relatadas serão observadas com base em três categorias analíticas, referentes às três etapas da medicalização explicitadas aqui:

a. a emergência do problema, que compreende perceber o sofrimento como necessidade de saúde e encontrar canais de expressão no serviço que permitam enunciá-lo; quando a enunciação é possível, é necessário que seja escutado pelo profissional, gerando

b. o acolhimento recebido, em termos da qualificação que as profissionais dão a esta emergência e a continência que é possível e,

c. o trabalho realizado com a demanda, no sentido de propostas de respostas, internas ao serviço ou externas, em uma rede mais ampla, e sua efetivação na vida da mulher.

Buscaremos, nos discursos produzidos e ações realizadas, as intenções e motivos dos agentes que explicam ou justificam as ações relatadas (D'OLIVEIRA; SCHRAIBER,1999), (SCHRAIBER; D’OLIVEIRA, 1999b). 
Analisaremos a interação comunicativa no interior do serviço entre usuárias e funcionárias(os), em seus aspectos estratégicos e comunicacionais. Empreenderemos a interpretação destes discursos e ações na busca de agregarmos mais sentidos à experiência concreta da busca de serviços de saúde por mulheres em situação de violência e seus desdobramentos.

Ressalte-se que é o momento interativo captado por meio da observação direta que traz o principal eixo problemático de nosso estudo. Os momentos de relato individual de parte a parte (usuárias e profissionais), bem como o estudo do registro dos atendimentos, são fontes adicionais para o entendimento desta interação usuária-serviço. Assim, a gênese da situação de violência e sua tomada pelas mulheres como uma necessidade de saúde, que se dá no âmbito doméstico, permite entender como tais situações geram movimentos e expectativas junto ao serviço de saúde. Neste, os profissionais, com base em sua identidade de agentes de um dado trabalho social, com uma forma de intervenção própria, manterão uma interação que deriva tanto do sentido tecnológico que os movimentos e expectativas postos pelas mulheres possam assumir, tornando-se, pois, demandas específicas por intervenção, quanto ao sentido propriamente "ético" que estes movimentos e expectativas, traduzidos nas falas das usuárias possam provocar, como vivência/evocação de experiências humanas compartilhadas ou compartilháveis, seja como uma mesma realidade material vivida, seja comovalor ${ }^{1}$.

O material coletado será interpretado, portanto, como discursos e ações de agentes em relação, no interior das práticas de saúde. De um lado, temos os agentes/pacientes, sujeitos que buscam resolver questões concretas de saúde, e de outro, os agentes/profissionais, sujeitos técnicos que buscam fazer seu trabalho da melhor forma possível.

${ }^{1}$ Inspira-nos o quadro referencial e a metodologia usados por AYRES (1997) para examinar, do ponto de vista hermenêutico, as narrativas que constam dos discursos produzidos na criação do conceito de risco em Epidemiologia como saber e prática de saúde. Para um aprofundamento da abordagem do trabalho em saúde como interação, ver, ainda, SCHRAIBER (1997) e PEDUZZI (1998). 
Realizaremos uma análise de pequenos fatos do cotidiano, que são relatados em situações particulares de atenção à saúde. Trabalhamos com um conjunto de falas e ações cotidianas que dizem respeito às relações intersubjetivas. Estas falas referem-se, muitas vezes, a questões da esfera privada, problemas práticos do mundo da vida que são enunciados sob sigilo na esfera social representada pelos serviços de saúde e que demandam soluções. Não julgaremos aqui o quanto estes relatos, ou mesmo as informações técnicas prestadas por profissionais de saúde são verdadeiras ou não, no sentido do quanto correspondem "realmente" aos fatos ocorridos ou ao conhecimento científico. Em relação aos relatos observados, isto seria até impossível, já que eles descrevem ações já passadas. As falas são, entretanto, interpretações destas ações que, ditas em determinado contexto, objetivam tais ações e produzem determinados efeitos. Assim, a fala será interpretada como uma ação que intenciona produzir e produz concretamente efeitos (AUSTIN, 1990). É esta força ativa da fala, como forma de comunicar, agir e provocar ações e falas nos outros que nos interessa analisar, pois a fala convida à escuta e à ação do outro (que pode ser uma intervenção técnica), estabelecendo a relação. Importará o relato e interpretação de sujeitos que falam de sua própria perspectiva em um determinado local e para um público específico. É esta perspectiva que deve ser levada em conta e descoberta na análise do diálogo estabelecido.

O serviço eleito para estudo foi o CSE Samuel B. Pessoa. O CSE foi escolhido por apresentar o PAISM bem implantado e funcionando extensivamente, o que era fundamental para o desenho da pesquisa ${ }^{3}$.

${ }^{3}$ Entende-se por bem implantado o fato de o serviço apresentar a maioria das ações previstas pelo PAISM, ainda mais se cotejado com avaliações realizadas nacionalmente (COSTA, 1999). Entende-se por funcionamento extensivo o fato de o serviço apresentar um volume de demanda bastante expressivo, ao ser comparado com outras unidades da Secretaria de Estado da Saúde da mesma região da cidade. 
Ao mesmo tempo, o CSE reproduz as condições concretas da rede básica de saúde, ainda que com diversas vantagens em termos de possuir também atividades regulares de treinamento de pessoal e supervisão, fichas padronizadas para os diversos tipos de consultas arquivadas em prontuários e uma cultura institucional de avaliação já implantada. A facilidade operacional para a realização do campo que, devido à observação das atividades assistenciais envolvia detalhes sensíveis, também foi levada em consideração nesta escolha.

Ao escolher o CSE e algumas de suas usuárias para estudo, não pretendemos tomá-lo como uma amostra de um universo maior no sentido estatístico, o que não faria sentido para o desenho de pesquisa apresentado aqui ou para seus referenciais teórico-metodológicos.

O tipo de representação que o estudo do serviço pretende é aquele da perspectiva qualitativa de aproximação de realidades socioculturais dadas, isto é, que nos ajuda a compreender como pessoas específicas, neste lugar e nesta época determinada, vivem e consomem serviços de saúde, e os significados que atribuem a isto (MINAYO, 1992, DENZIN, 1994). Para tanto, buscamos uma descrição densa (GEERTZ, 1989) das atividades observadas, com o máximo de detalhes, que nos permita fazer idéia do sentido atribuído pelos sujeitos às palavras e ações realizadas. Cada indivíduo observado ou entrevistado é para nós uma expressão particular de um determinado coletivo social e histórico. Por isto, embora se expresse de modo inteiramente próprio, cada personagem fala e age articulando conceitos e valores relativos à sua época social, expressando uma determinada possibilidade histórica de ser social. Ao buscar esta dimensão a um tempo coletiva e individual nas falas e ações de sujeitos particulares, procuramos conhecer, por meio deles, um pouco mais sobre o problema estudado. Este conhecimento pode então auxiliar a compreender outros serviços, outras pessoas e outros contextos, ao ser aplicado em novas realidades de mesmo tempo histórico e social. 
Outra questão importante a ser considerada em relação ao trabalho de campo é a profunda vinculação que a pesquisadora tem com o serviço estudado. Isto deve ser dito porque esta pode ser tanto uma dificuldade adicional para a análise do material, como uma facilidade. Se, por um lado, há a situação privilegiada para se compreender a arquitetura e o funcionamento do processo de trabalho e interação, em cuja implantação e supervisão se está envolvida, esta proximidade pode "embaçar", ou "viciar" o olhar, já acostumado com o modelo, perdendo em possibilidades críticas. Para amenizar este risco, buscou-se utilizar diversos observadores de campo independentes, e que foram cotejados entre si nas supervisões da equipe realizadas. Só após este procedimento, os achados foram definitivamente registrados como dados da pesquisa.

A adoção destes cuidados no campo teve como objetivo buscar distância de uma realidade muito próxima, pois nosso princípio básico, tendo em vista o olhar sociocultural almejado, consistiu na busca de estranhar aquilo que nos é familiar. Entenda-se que o sentido do estranhamento não se refere à tradição das pesquisas avaliativas, isto é, à pesquisa do cumprimento das normas e regras programáticas e à correção técnico/política do trabalho assistencial, como é necessário e nos cabe realizar no trabalho gerencial cotidiano. O estranho aqui diz respeito à busca das possibilidades e limites da incorporação do problema violência ao trabalho em saúde, em especial o da atenção primária na forma PAISM.

Neste sentido, trata-se de verificarmos algo novo na prática dos serviços e avaliarmos o andamento da estrutura já existente na proposta por nós implantada. Em outras palavras, não se trata de uma avaliação, quer de processo, quer de produto, quanto a uma norma pré-estabelecida de ações tidas como padrão-ouro na qualidade esperada de produção de serviço. Diferentemente, buscamos antes de tudo compreender se, e como, mulheres em situação de violência poderiam se constituir em alvo da prática destes profissionais, por meios do exame das condições já dadas de sua constituição como usuárias de um serviço determinado. 
Ora, este objeto, por outro lado, descortina de modo bastante radical a dupla característica do trabalho (HABERMAS, 1987): a produção de intervenção, que visa resultados, e a interação humana, que remete imediatamente a questões éticas bastante complexas no caso da violência. Ao trabalhar com o problema-violência, não somente se coloca como questão os produtos tecnologicamente alcançados pela ação do trabalho dos profissionais. Este problema, por sua natureza, faz ressaltar a dimensão interativa do trabalho. Por isso, o serviço não ficou incólume à proposição e realização do estudo em seu interior. Os profissionais conheciam a pesquisa e, algumas vezes, seu andamento foi apresentado para os médicos, pessoal de enfermagem e pesquisadores da equipe da Saúde do Adulto do CSE. A partir de 1996, passamos a contar também com diversas referências para o trabalho com a questão, reunidas em um Guia de Serviços para o Atendimento a Mulheres em Situação de Violência (GUIA DE SERVIÇOS, 1999), que é utilizado até hoje.

O processo da pesquisa, desta maneira, modificou a percepção, o acolhimento e o trabalho da violência por parte dos profissionais do CSE. Esta modificação decorreu da interação com a pesquisa, que sempre se observa em investigações deste tipo, resultando em produtos que são uma verdadeira intervenção que acompanha o processo de investigação.

Do ponto de vista deste impacto ao longo do trabalho de campo, cabem aqui as mesmas recomendações que já são usuais na pesquisa qualitativa: todo o entrevistado, ao produzir depoimentos pessoais ou narrativas sobre uma questão, termina por refletir criticamente sobre esta mesma questão, com o que se torna "cúmplice" do registro para a ciência (SCHRAIBER, 1995, BOSI, 1983). Estas mudanças ocorridas no serviço só fizeram realçar aquilo que buscamos observar, ou seja, as possibilidades e limites para que demandas conexas ao problema violência tenham emergência, acolhimento e resposta na atenção primária, e são vistas aqui como positivas para a produção de conhecimento. Lembramos que não procuramos um percentual de detecção de violência com ou sem busca ativa, mas, 
sim, as potencialidades de trabalho com o tema, quando de sua emergência no interior de ações de saúde.

\subsection{A observação das atividades assistenciais}

Das 57 atividades assistenciais observadas, 16 foram atividades grupais e 41 atividades de assistência individual.

Os 16 grupos foram assim divididos: seis grupos de Contracepção, cinco grupos de resultado da Prevenção do Câncer ginecológico e cinco grupos de Saúde da Mulher. Os grupos são pensados como tecnologias tanto educativas como assistenciais, sendo o de Contracepção e o de Saúde da Mulher principalmente educativos. O de Saúde da Mulher, experimental à época da pesquisa, tem características próprias ao CSE; trata-se de grupo de recepção para demandas relativas à "saúde da mulher em geral" A partir da escuta no grupo, a mulher é encaminhada para as atividades, internas ou externas, que melhor se adaptem à sua necessidade expressa.

As 41 consultas individuais observadas distribuíram-se da seguinte forma: 20 atendimentos de enfermagem para coleta de material para citologia oncótica e exame de mamas, sete atendimentos de enfermagem de recepção à demanda, oito primeiras consultas de pré-natal e seis primeiras consultas com o ginecologista.

O registro da observação foi feito em três modalidades:

a. gravação dos diálogos estabelecidos;

b. registro detalhado, seguindo a tradição etnográfica de observaçãoparticipante;

c. registro posterior ao ato de observação, contendo impressões sobre os atendimentos, questões levantadas pela observação e anotações sobre 
o andamento de todo o processo da pesquisa, seguindo a tradição de caderno de campo.(GEERTZ, 1989)

Os roteiros utilizados para este trabalho encontram-se no anexo 1.

A observação das atividades foi nosso ponto de partida. Ali pudemos registrar diretamente a interação das mulheres com os profissionais no serviço, sendo, por isto, como já comentado, o núcleo de nosso estudo. As outras técnicas utilizadas visaram a acrescentar outras perspectivas a este ângulo de visão.

Durante esta fase do trabalho de campo, embora todos soubéssemos da alta prevalência da violência contra a mulher, relatada pela bibliografia internacional, a impressão é de que buscávamos algo muito raro, algo assim como buscar uma agulha em um palheiro. Os pesquisadores de campo desanimavam, pois parecia tolice assistir a grupos ou consultas, esperando alguma fala que se referisse à violência. Não parecia possível esta emergência naquele contexto, permeado de termos biomédicos. A equipe sentia uma recusa ou resistência em falar desta questão difusa na própria assistência, mas, ao mesmo tempo, percebia uma contradição, já que a assistência oferecida era vista como de boa qualidade em relação a outros serviços da rede pública. Em suma, o desconcertante era que, embora se percebessem no trabalho diversas recomendações propostas pelo PAISM, no sentido de acolher a mulher e todas as suas questões como sujeito social e em especial em sua condição de gênero, estas não pareciam suficientes para propiciar a emergência de temas como o procurado e, ao contrário, algumas atitudes, falas e sessões de assistência eram em si mesmas percebidas como recusa ao acolhimento sugerido pelas normas do PAISM e, por isto, "violência", na opinião dos pesquisadores de campo. A normatividade médica e da enfermagem, a "cassação" de palavra das usuárias, a falta de respostas objetivas e os longos discursos morais foram os primeiros aspectos que chamaram a atenção do grupo. 
Durante o campo, a percepção foi de maior tensão na observação das atividades grupais. A nosso ver, isto ocorreu, entre outras coisas, porque estas atividades permitem um espaço maior para a fala das usuárias, o que torna a possibilidade de emergência de um relato de violência mais presente. Esta possibilidade antevista também parece deixar mais aparentes as estratégias do serviço para ocultar estas falas, o que explicaria a tensão sentida pelos pesquisadores. Já as consultas individuais, mais controladas em termos do diálogo possível de ser estabelecido e da ritualística da consulta, não propiciam sequer a "ameaça" de emergência de questões mais complexas, passando uma impressão de maior controle e "assepsia", e foram menos questionadas não só pelas mulheres, mas pelos próprios observadores em termos de suas potencialidades para a emergência de relatos acerca da violência. Na ausência de condições de emergência, fica inviabilizada a possibilidade de lidar com o problema como tal nos serviços de saúde.

A transcrição de trechos da observação realizada será grafada em itálico neste trabalho, como este parágrafo. A fala dos profissionais será indicada por Prof., a fala das pacientes por M. e quando a pesquisadora falar será indicado pela letra $P$.

\subsection{Os prontuários e o uso dos serviços}

No CSE estudado, o registro é padronizado, e cada tipo de atendimento tem um formulário próprio (SCHRAIBER et al, 1996). Nas fichas de atendimento Prénatal, preenchidas por médicos e enfermagem, e também na de atendimento ginecológico, existe a menção explícita a situações de violência como uma das questões psicossociais a serem abordadas na anamnese.

A leitura do prontuário buscou caracterizar o tipo de uso de serviço das mulheres observadas, suas queixas, diagnósticos e condutas. Buscou-se também o registro explícito de situações de violência. O material foi analisado em função de três categorias: violência física e sexual, contexto de violência e conflitos relativos aos 
direitos reprodutivos. Para elaborar estas três categorias, todos os 142 prontuários foram lidos várias vezes, por pesquisadores independentes e posterior cotejamento, como já dito, até chegar ao "mapa" final de leitura.

$\mathrm{Na}$ categoria violência, incluímos os registros que diziam respeito à violência física recebida ou cometida e especificamente violência sexual. $O$ contexto diz respeito a falas que mostram um ambiente que propicia ou prenuncia violência, compreendendo indicadores como brigas, insultos, violência entre outros membros da família e ameaça de suicídio. Por último, agrupamos freqüentes relatos de conflitos em torno da reprodução e sexualidade, como ter ou não filhos ou tratar ou não de doenças sexualmente transmissíveis, que definimos como questões relativas aos direitos reprodutivos. Estas categorias encontram-se expostas no anexo 5, em conjunto com os resultados desta etapa do trabalho.

De todos os prontuários, foram anotadas as queixas e diagnósticos de cada mulher a cada vez que comparecia ao serviço, assim como o tipo de modalidade assistencial utilizada, e os registros de violência, contexto e direitos reprodutivos encontrados. Estes registros foram analisados transversalmente, para percebermos que tipo de modalidade assistencial propiciou mais emergências de que tipo, e verticalmente, para estudarmos o contexto de uso de cada uma das mulheres que apresentou algum desses registros.

Os 142 prontuários foram também organizados em um banco de dados que contém a data de ingresso no serviço, data da última consulta e a quantidade de consultas e faltas no período por tipo de atendimento, o que nos possibilitou caracterizar as usuárias em sua diversidade de consumo de serviços (Banco analisado no Epi-info 6).

maneira transcrição de trechos dos prontuários será grafada desta 


\subsection{As entrevistas individuais com mulheres em situação de violência}

As entrevistas individuais foram a última e a mais difícil etapa de todo o processo, pois as entrevistadas foram identificadas nas etapas anteriores de observação participante e estudo dos prontuários. A princípio, mandamos carta para todas as mulheres que apresentaram alguma situação considerada como violência na observação de atividades assistenciais ou nos relatos de prontuários, convidando-as para uma entrevista. Nenhuma delas respondeu. Então, procuramos todas elas em seus domicílios, no endereço que constava de seu prontuário. Todas as mulheres foram procuradas; quatro não moravam mais no mesmo endereço, ou haviam dado o endereço falso, duas se recusaram a participar da pesquisa e uma havia morrido. Cinco mulheres foram entrevistadas.

A maioria delas morava em regiões de favela próximas ao serviço. Contrariando nossa ingênua impressão inicial, as mulheres que buscávamos, longe de encaixar-se em um estereótipo de sofrimento e passividade, eram muitas delas bastante assertivas. Mulheres de todo o tipo, comuns, sem nada aparente que evidenciasse seu drama, pressuposto pelas histórias relatadas no serviço. A proposta da entrevista foi explicada em detalhes, assim como o sigilo envolvido na investigação. Por ser uma história de vida, podia durar de duas a três sessões e mobilizar fortemente a entrevistada, que revê sua trajetória com uma interpelação crítica. Após tudo explicado, aquelas que concordaram em dar a entrevista assinaram o consentimento informado.

Apenas uma das mulheres contatadas consentiu em realizar a entrevista no domicílio, como propusemos inicialmente. Todas as outras quatro preferiram realizá-la no serviço de saúde. Algumas explicaram esta opção como uma forma de estar longe do marido, ou ironicamente, como uma forma de não colocar as pesquisadoras em risco de violência urbana, no caso de entrevistadas que 
moravam em favelas (ninguém morre sem motivo na favela, mas pode vir uma bala perdida, ou matarem alguém na minha rua...).

A entrevista continha um roteiro de questões a serem abordadas em profundidade (anexo 3), mas foi conduzida com o mínimo de interferência possível, como um depoimento oral (SCHRAIBER, 1995). Pedíamos para que a mulher nos contasse sua vida, passando por marcos importantes, e depois perguntávamos mais especificamente sobre os usos de serviços de saúde e sua avaliação destes usos. Deixávamos que tivessem seu próprio fluxo narrativo, e as perguntas eram colocadas apenas quando algum tema previsto não era abordado espontaneamente. A pessoa entrevistada, ao relatar, estimulada por perguntas determinadas, realiza um trabalho sobre suas lembranças, percepções e valores, e estrutura um relato oral que expressa sua visão particular do coletivo em que está inserida (BOSI, 1983).

A produção do relato não foi difícil de realizar e, algumas vezes, fluía quase sem interrupção. As questões relativas ao uso dos serviços de saúde e sua relação com a violência pareciam mais difíceis de serem compreendidas. A associação dos sintomas ou queixas com a violência era para elas uma obviedade. Já remeter a própria violência para os serviços de saúde não parecia fazer o menor sentido. As mulheres estranhavam questões que indagavam sobre o papel do SS neste problema. Parecia a elas muito distantes, já que "eles (os médicos) não têm tempo nem para a dor (física)" $\ldots$

Por outro lado, falar sobre a busca dos serviços quando se percebe alguma doença também parecia bastante óbvio. É como se esta busca fosse tão evidente que realmente não precisasse de justificativa. O uso de serviços de saúde em geral foi recomendado para tudo o que possa eventualmente ser doença, na percepção das entrevistadas, pois só o médico pode reconhecer se é mesmo ou não. Algumas entrevistadas recomendaram também o uso do serviço em geral, como uma 
espécie de prevenção para futuras doenças (é bom ir ao serviço todo o mês). Outras buscaram afastar-se do estereótipo de grandes consumidoras do serviço, enfatizando que quase não vão ao médico, ou que só vão quando estão precisando muito, o que contrasta com o uso efetivo observado, bastante intenso. Como se verá adiante, o uso do serviço de saúde para o problema violência dar-se-á geralmente mediado por uma demanda relacionada com algum adoecimento.

Das cinco entrevistas, a maior durou oito horas, e a menor, uma hora. As outras três tiveram uma média de três horas. Todas resultaram em 413 páginas quando transcritas.

Depois de transcritas, as entrevistas foram editadas. Na edição, tiramos as perguntas realizadas pelas pesquisadoras $e$ as informações relativas a acontecimentos conjunturais, além das inúmeras repetições da mesma fala. Quando esta última situação aconteceu, marcamos em negrito estas expressões. A ordem das falas permaneceu o mais próximo possível da ordem dada pela própria mulher a seu discurso, pois a entrevista, deixando espaço para a associação livre, permite que a interpretemos levando em conta também esta estruturação.

As entrevistadas receberam o material transcrito e editado, impresso em uma cópia para elas. Uma não quis o material, alegando que não queria uma história tão triste. As outras se mostraram bastante satisfeitas e não tiveram preocupações da ordem de sua segurança com a posse do material, assunto que levantamos ativamente. Uma delas mostrou interesse em encadernar o material para guardar "como um livro".

As entrevistas individuais de usuárias e de profissionais estarão indicadas no texto pela fonte utilizada, tal como grafado aqui. Sempre que esta fonte for utilizada, indicará que a origem da citação é um depoimento deste tipo. 


\subsection{As entrevistas individuais com os profissionais médicos e de}

\section{enfermagem}

Entrevistamos dois profissionais médicos e duas auxiliares de enfermagem. A entrevista foi semi-estruturada, conduzida por um roteiro que solicitava a posição dos trabalhadores acerca da conexão da violência com a saúde e explorava as categorias definidas por SUGG \& INUI (1992), como limites para a atuação profissional com o tema, e já expostas aqui anteriormente.

Os profissionais foram escolhidos como tipos extremos entre os grupos observados. Estes tipos foram criados com base na análise da observação participante, e buscaram definir dois pólos, relativos ao desempenho concreto do profissional em criar ativamente canais de comunicação com as usuárias para a expressão de questões não estritamente biomédicas. Desempenho profissional refere-se aqui à síntese da interação indivíduo-instituição, que se expressa no trabalho cotidiano, por meio do agir profissional concreto e particular a cada situação de trabalho (SCHRAIBER, 1993). É por isto uma categoria que tanto diz respeito às normas de trabalho quanto às características do profissional que as introjeta e exterioriza na forma de um agir prático.

Assim, estes pólos representam o agir mais ativo no sentido de respeitar e abrir canais de comunicação, e aquele que prioriza o agir estratégico, mesmo que em detrimento da possibilidade mais ampla de interação comunicacional. Dois profissionais foram escolhidos por representarem o desempenho mais tradicional, centrado no discurso biomédico. Os outros atuavam ao revés, acolhendo mais ativamente os canais emergentes de expressão próprios da usuária. A entrevista, também gravada e conduzida com um roteiro semi-estruturado (anexo 4) tinha a intenção de discutir alguns dos obstáculos descritos na literatura para o trabalho com a violência, assim como explorar a experiência e percepções desses profissionais sobre o tema da violência contra a mulher e sua presença no trabalho 
em saúde, em especial, também lidando com o desempenho profissional concreto que cada qual apresentou à observação participante.

Deve-se registrar ainda que todos esses profissionais representam, do ponto de vista do PAISM e da atenção primária em saúde, trabalhadores bem qualificados e tecnicamente competentes diante do recomendado. São profissionais que foram considerados como dominando tanto as dimensões educativas quanto aquelas de caráter terapêutico previstas pelo programa. Portanto, excluímos da análise a possibilidade de má prática profissional, que levantaria ainda outras questões em relação ao problema aqui tratado. Isto se deu perante a opção metodológica tomada de verificar a possibilidade de trabalho com a violência contra a mulher no interior de um serviço com o PAISM bem implantado, e boas condições de trabalho e prática profissional.

Apesar de serem igualmente competentes, diante do problema violência, como foi observado, estes profissionais diferenciam-se entre si. É diante deste problema novo, para o qual não há normas institucionais claras ou saber tecnológico definido, que esses profissionais revelam diferentes consensos sobre o sentido mais geral do trabalho do PAISM e da atenção primária à saúde, o que será explorado na análise. 


\section{Princípios de interpretação e análise do}

\section{material empírico}

\subsection{Linguagem, poder e violência nos serviços de saúde}

Vamos agora precisar melhor o conceito de violência que será utilizado aqui. Como já foi colocado, a delimitação precisa do problema violência é uma das grandes questões para o campo, e não existe uma definição única e consensual para o problema violência contra a mulher. As diversas concepções existentes na área do feminismo e da saúde pública não nos pareceram completamente adequadas para a perspectiva aqui adotada. Uma das dificuldades sentidas diz respeita à interrelação entre os conceitos de relações de gênero e violência. Como já trabalhado anteriormente, uma das grandes discussões no campo é a respeito de quão amplos são os limites daquilo que é considerado violência. Os pesquisadores se dividem entre aqueles que acham que toda discriminação de gênero é uma forma de violência, até aqueles que defendem limites estreitos para o conceito, geralmente ancorados em lesões físicas intencionalmente produzidas. Concordamos que a violência contra a mulher está articulada com as relações de gênero, mas qual a sua conexão exata? Seria a violência apenas uma das formas, mais explícita e evidente, de exercício de poder nas relações de gênero? Esta concepção, bastante popular, não nos satisfez, pois estabelece limites apenas quantitativos entre poder e violência e não pode precisar este limite. Por outro lado, ela pode ser monolítica e não dar espaço para a mudança, nem para o exercício de poder pelas mulheres e usuárias, quando se entende que todo exercício de poder é exercido por homens contra mulheres, sendo a violência apenas mais um meio para a perpetuação deste poder. 
Buscávamos uma concepção que pudesse nos propiciar uma análise mais relacional e potencialmente positiva de poder, para se coadunar com os referenciais aqui adotados, deixando espaço para a possibilidade de interação comunicacional, mudança e crítica. Encontramos este potencial no trabalho de Hannah Arendt, que se dedicou ao estudo da violência, recusando a definição do poder como uma ação de controle e domínio do outro, e propondo a comunicação intersubjetiva e a ação humana livremente acordada como a verdadeira e legítima fonte de poder.

ARENDT (1994) em seu livro Sobre a violência trata especificamente deste tema, apresentando o conceito de poder de Max Weber e da maioria dos teóricos ocidentais modernos. Ela afirma que, para estes autores, poder é a capacidade humana de "impor a sua própria vontade, dentro de uma relação social, mesmo em face de resistência". Segundo a autora, estes estudiosos partem de um modelo teleológico de ação: um sujeito individual (ou grupo) se propõe um objetivo e escolhe os meios apropriados para realizá-lo. O sucesso da ação corresponde à aquisição do objetivo final. À medida que esta aquisição dependa do comportamento de outros sujeitos, o poder consistiria na capacidade de dispor dos meios para influenciar a vontade destes sujeitos com capacidade decisória própria, seja pela ameaça de sanções, pela persuasão, ou por uma manipulação hábil das alternativas de ação. Para esta tradição, que é extremamente difundida nos dias atuais, a violência seria uma das formas de manifestação do poder, uma forma mais ostensiva e evidente do exercício de dominação para a aquisição de um determinado fim. Para os estudos de mulheres, esta foi também a primeira concepção de violência contra a mulher dentro dos marcos conceituais do patriarcado. A violência seria, nesta visão, um dos meios para a manutenção do poder masculino.

Portanto, a distinção que estamos propondo entre violência e poder não é a mais usual nos estudos sobre o poder. Para nós, este modo de compreender quer o 
poder, quer a violência, dificulta uma distinção de qualidade entre ambos, ao revelar-se a violência como um "excessivo" uso ou grande grau de poder.

Hannah Arendt prefere fazer uma distinção entre os termos poder e violência, criticando e rompendo com a equivalência entre política e poder, de um lado e governo e dominação, de outro. Resgatando a pólis grega e seu espaço público, a autora lembra que o essencial da política não é a dominação ou o governo dos outros para os próprios fins, mas a possibilidade de emergência da pluralidade humana, a possibilidade de comunicação e ação compartilhada entre os homens. Para ela, o conceito teleológico de poder de Weber é a própria violência, já que o agente instrumentaliza os outros como meios para atingir seus objetivos, e não vê no entendimento com o outro um fim em si.

Arendt define poder como fundado na capacidade humana de conversar entre si e agir em conjunto. $\mathrm{O}$ poder estaria fundado, assim, na comunicação livre entre os homens e mulheres, voltada para o entendimento. Sendo práxis, o poder não pode ser possuído ou acumulado. O poder gerado na comunicação livre cristaliza-se em instituições e postos de poder, cujos ocupantes assumem funções de governo. Instalados nestes postos, os governantes podem até usar a violência como um de seus instrumentos para a manutenção neste posto. Mas estes meios são incapazes de manter o governo, se forem perdidas as bases legítimas de geração de poder: a intersubjetividade humana livre. Arendt lembra que quando desaparece o suporte do "poder vivo do povo", estas instituições políticas petrificam-se e decaem, como o demonstram os momentos revolucionários.

As instituições, para se manterem vivas, deveriam preservar as frágeis bases da práxis comunicativa que são a fonte geradora de seu poder. O uso da violência, para Arendt, denota impotência. Este uso seria apenas um meio de manutenção dos governantes nos postos de poder, quando já não há base legitima intersubjetiva para sustentá-los. Os meios para a violência podem ser acumulados, 
no limite, por uma só pessoa. Podem causar obediência, mas não podem gerar poder. A violência obstaculiza a interação entre as pessoas, impede a ação conjunta, quebra as possibilidades de união. A violência destrói o poder, porque impede a fala, a interação comunicativa e as ações humanas solidárias que geram o poder legítimo.

Se a distinção que Arendt faz entre poder e violência nos parece adequada, e embora a ênfase na ação comunicativa como geradora de poder seja extremamente importante pelo peso que esta constatação tem na idéia desenvolvida aqui, a definição ainda não está completa para nossos propósitos, pois Arendt acaba por definir toda ação voltada a fins como violência.

As questões levantadas por HABERMAS (1980), em sua crítica à noção de poder e violência em Hannah Arendt, podem iluminar o problema levantado e recolocar a forma de aproveitamento que podemos fazer de Arendt.

Habermas concorda com a idéia de Hannah Arendt de que a base legítima do poder é a comunicação livre entre as pessoas e a possibilidade de ação conjunta. Mas, para ele, a definição de Arendt, que exclui toda a ação humana teleológica do conceito de poder, tem dificuldades de adaptar-se a um espaço público moderno e real que, diferente da pólis grega, não é uma arena onde iguais conversam entre si, mas, sim, espaço em que sujeitos e grupos privados buscam garantir interesses particulares e, muitas vezes, contraditórios. Em situações de grandes desigualdades estruturais, argumenta ele, não se pode usar o mesmo conceito de política da pólis grega, cidade de iguais (ao menos entre os cidadãos), que reservava a ação estratégica para fora dos muros da cidade. Grupos em situação desvantajosa podem e devem empreender ações estratégicas para a conquista de poder, enquanto não houver igualdade de condições de expressão para todos.

Habermas pergunta: Se o poder é gerado quando há interação humana livre e os homens agem em acordo, como explicar que, nas sociedades modernas, 
mesmo na ausência da repressão política e da censura, com o debate público garantido, este poder assim gerado seja em grande parte contrário aos interesses daqueles que o geraram? O que define uma comunicação livre, que gere poder legítimo?

O autor responde que a violência estrutural, nas sociedades modernas, bloquearia imperceptivelmente o processo comunicativo, gerando ideologia.

“Em processos comunicativos sistematicamente limitados, os participantes formam concepções subjetivamente não coercitivas, mas ilusórias; com isso, geram comunicativamente um poder que pode ser usado contra esses mesmos participantes, no momento em que se institucionaliza". (HABERMAS, 1980 :117)

Esta limitação sistemática dos processos comunicativos é parte do que estamos chamando aqui discurso competente. Se o discurso representa totalidades de falas articuladas capazes de apresentar o pensamento de sujeitos em situação, expressando interações dadas, o valor social desigual dos discursos gera ideologicamente linguagens e falas tidas como mais competentes que outras para expressar determinadas realidades, como nos mostra CHAUÍ (1993). A linguagem competente do discurso médico bloqueia a fala, pois limita e enquadra o tipo de proferimento que deve ser enunciado acerca do adoecimento e de toda a experiência de sofrimento potencialmente vinculado ao adoecer. Esta desigualdade de fala ocorrerá no interior da consulta, ainda que os dois participantes (pacientes e profissionais) estejam de acordo voluntariamente com estas regras discursivas. Assim, o mundo da vida é progressivamente colonizado pelo mundo do sistema, gerando o paroxismo instrumental da vida moderna. No exercício desta forma de interação basicamente estratégica, no entanto, há chances para uma maior ou menor liberdade de comunicação, que está dada tanto pela organização institucional como pela criatividade dos sujeitos presentes para inovar e encontrar, em regras de linguagem sistematicamente limitadas e discursos lacunares, espaços 
para críticas a estes limites e lacunas, e encontrar novas potencialidades de expressão e geração de respostas comunicacionais. Isto poderá ocorrer quando cada um dos participantes buscar se apropriar de linguagens que possibilitem retorno ao compartilhável, ainda que tal linguagem pertença genuinamente a um dos indivíduos da interação e ao outro apenas estrategicamente. Note-se aqui, que procedemos à adoção de dois pressupostos:

1. Falas proferidas podem provocar no outro participante da relação (ouvinte ou leitor) uma resposta, quando há linguagens compartilháveis e desafios interpretativos, o que permite continuidade comunicacional (AUSTIN, 1990);

2. A comunicação ocorre em graus diversos de liberdade interativa, sendo máxima quando os dois sujeitos presentes ao diálogo compartilhem expectativas de verdade proposicional (o sentido lógico do que é dito), validade normativa (os valores em relação ao que é proferido) e autenticidade expressiva (a assunção de que a fala é feita na primeira pessoa, e aquele que fala é genuinamente portador do proferimento), o que nos permite perceber uma distinção entre o agir comunicativo e a comunicação que resulta de agir estratégico (HABERMAS, 1980).

Temos, então, de um lado, a comunicação livre do agir comunicativo, que cumpre os pressupostos de validade comunicativa, que chamaremos de interação comunicacional, ou comunicação livre. De outro, a violência, em que pode haver sentido para um e outro ator, mas a pressuposição de compartilhar valores e sentidos e, portanto, linguagem, está rompida, porque o objetivo é forçar ou anular o outro, que não é reconhecido como sujeito, mas totalmente objetificado e sem alternativas de ação.

Entre estes dois pólos de comunicação livre, por um lado, e violência, por outro, temos as relações cotidianas, a comunicação sistematicamente distorcida pela ideologia e estrategicamente orientada, que pode orientar-se para a obstrução 
da comunicação, gerando violência, ou para a maior liberdade de comunicação, gerando poder (que tem aqui o sentido positivo cunhado por ARENDT(1980)).

A interação estratégica não será considerada, portanto, exercício de violência. Violência será para nós quando um dos pólos da relação encontra-se completamente subjugado e anulado, impedido, portanto, de qualquer opção de ação ou expressão, rompendo a possibilidade mesma de interação. Na violência, não há relação, busca de entendimento, ou mesmo de convencimento, que se tornam impossíveis pela perda dos significados compartilhados. A violência não precisa se explicar, ela não se justifica, nela não se argumenta. Quando começa a se explicar ao outro, já começa a deixar de ser violência; qualquer esforço comunicacional restabelece as relações de poder e tendencialmente pode suprimir a violência.

Se violência é não comunicação e não linguagem compartilhada, comunicarse e estabelecer códigos comuns e linguagens para tais pode ser exercício de poder. É o que vemos ocorrer no exercício cotidiano de poder dos discursos disciplinadores, como o da medicina, que produz efeitos práticos e está voltado para o convencimento. Serão, pois, relações de poder, que podem oprimir, mas também produzir interações em que são proferidos discursos caudalosos que obstruem sistematicamente uma comunicação "livre", no sentido habermasiano, e são observadas no cotidiano dos serviços de saúde. Nestas relações, muitas vezes as pressuposições de validade propositiva e normativa estão cumpridas, pela ideologia introjetada nos sujeitos usuários, que concordam e legitimam a autoridade profissional. Mas a autenticidade expressiva está rompida, já que os proferimentos de usuário e profisional não são necessariamente genuínos.

Se aqui temos um processo medicalizador em que o sofrer e o adoecer encontram sua linguagem (socialmente validada), vale lembrar analogamente outra relação de poder que é a de gênero. A autoridade médica e a autoridade 
masculina se constroem e são aceitas de forma mais ou menos crítica, de acordo com o momento e a autonomia ou heteronomia dos sujeitos presentes, gerando violência num extremo ou abrindo canais de comunicação, estabelecendo relações de poder e comunicação por vezes mais "livres", por vezes dominadas ideologicamente pela competência social do discurso hegemônico presente na relação.

Portanto, apesar de concordarmos com Arendt que a fonte do poder é a comunicação livre, partimos do princípio de que a comunicação no serviço de saúde não é deste tipo, sem que isto signifique sempre violência. Discurso competente, a linguagem no interior dos serviços tende mais à obstrução dos canais de comunicação livre que à sua manutenção. Esta obstrução sistemática pode gerar violência, segundo ARENDT e HABERMAS, já que obstrui as possibilidades de comunicação "livre". É neste ponto que a organização do trabalho tal como estudada por D’OLIVEIRA (1996) no PAISM adquire sua real importância técnico-política: o PAISM, nesta interpretação, potencialmente aponta como um valor a busca de modos de produzir a interação recíproca em uma relação comunicacionalmente mais simétrica. Com isso, o PAISM tensiona a hierarquia interna aos serviços e a supremacia do saber biomédico, e questiona as relações de poder no interior dos serviços. Esta proposta assistencial abre espaço para situações conflitantes e, nisto, dinamizadoras do processo medicalizador, com a expressão de demandas ainda sem linguagem "competente" (médica). Valendose de uma recriação desta linguagem, as próprias usuárias colocam em cheque uma prática profissional a princípio cheia de certezas, como veremos adiante.

Se serve a nossos propósitos para a observação do trabalho em saúde, entretanto, esta definição não se aplica da mesma forma quando nos referimos às relações estabelecidas pelas mulheres observadas no mundo privado. Por características próprias de nosso objeto, esta dimensão é bastante importante. Fora do mundo do sistema e do discurso competente, a relação entre familiares e 
pessoas íntimas faz parte do mundo da vida, o que requer ainda uma reflexão adicional na distinção entre poder e violência. Lançaremos mão, para isto, de um princípio filosófico que a nosso ver pode ser consistente com os demais referenciais teóricos adotados e que pode nos iluminar aspectos importantes deste estudo.

Este princípio é colocado por BUBER (s/data) em seu livro Eu e Tu. Para ele, existem duas palavras-princípio que não exprimem algo fora delas, mas uma vez proferidas, fundamentam uma existência. Elas dizem respeito a uma atitude dupla do homem com o mundo. Eu-Tu refere-se a uma totalidade que se encontra em outra totalidade - Tu, pela contemplação e pelo diálogo. O Tu pode ser outro sujeito, Deus, uma obra de arte ou a Natureza. Ao dizer Tu, o Eu diz também Eu e se reconhece. A segunda palavra princípio, que é logicamente posterior a esta primeira, é Eu-Isso, e diz respeito a um Eu que não é mais uma totalidade, mas que tem um limite. Fora do Eu, há o Mundo, com diversos issos que se apresentam para a experiência do Eu. A palavra Eu-Isso refere-se à experiência do mundo. O Isso pode ser uma coisa ou uma pessoa ( Ele-Ela), mas está fora do Eu, como algo a ser manipulado, experienciado, transformado. Estas duas atitudes perante um mundo dual forjam as possibilidades da existência. É a relação Eu-Tu que estamos valorizando aqui, como atitude possível contra a violência. Esta atitude diz respeito a um gesto ético inicial e fundador, que não necessita explicação nem justificativa. Se, como já discutido, a modernidade autoriza a todos desejarem uma vida boa e justa para si como um direito universal, desejar a mesma vida para os outros já é um ato ético fundador que não tem a mesma universalidade, já que depende deste "gesto" inaugural. Interessar-se pelos outros é este gesto inicial que funda a existência ética de um sujeito que almeja a vida boa e justa (HELLER,1992) para todos os humanos, pois preocupa-se com eles. Esta fundamentação ética é inicial e intransitiva. Não há um motivo para que se aceite que isto é bom, mas este é um princípio colocado por nós como fundante para este trabalho. Assim, esta será nossa fundamentação primeira das relações examinadas aqui. 
Até este ponto nos preocupamos em diferenciar poder, violência, comunicação e linguagem. Vamos agora ver como estas distinções podem ser tematizadas no interior do trabalho em saúde, em que estaremos estudando as possibilidades e conexões entre comunicação, linguagem, exercício de poder e emergência de situações de violência.

\subsection{As práticas em saúde: trabalho em saúde e interação}

É núcleo central do quadro teórico aqui utilizado, a teoria do trabalho em saúde, tal como originalmente desenvolvida por MENDES-GONÇALVES (1994) e posteriormente retrabalhada por AYRES (1997), na perspectiva da ação comunicativa; por SCHRAIBER, (1993; 1997), do ponto de vista da atuação profissional do médico; e por PEDUZZI (1998), da perspectiva do trabalho em equipe.

MENDES-GONÇALVES (1992) com base na teoria marxista do trabalho, mostra-nos que o trabalho em saúde responde a finalidades colocadas pela vida social, satisfazendo necessidades de saúde historicamente determinadas. Para ele, toda a ação no trabalho só tem sentido tecnológico se puder apreender o objeto de trabalho, tendo em vista um produto final que satisfaça a necessidades sociais de saúde históricas e socialmente determinadas, dispondo, assim, dos meios para transformá-lo nesta direção. Objeto, produto e instrumentos do trabalho são, então, analisados como partes de um processo intrinsecamente articulado à finalidade e necessidades historicamente colocadas, e o trabalho só pode ser compreendido em seu conjunto. São necessidades sociais de saúde aqueles carecimentos para os quais se pode antever a satisfação nos produtos obtidos pela ação deste trabalho em uma determinada época histórica. $\mathrm{O}$ agente que opera este trabalho $\mathrm{o}$ faz contemporaneamente utilizando um saber complexo que, amparado no conhecimento científico e na experiência de trabalho do profissional, se faz saber 
técnico, transformador da realidade. Este saber, conceptualizado como saber operante, instrui o trabalhador durante todo o processo de trabalho, no sentido de conduzir a transformação para o sentido desejado e esperado, a fim de que se cumpra a finalidade social e a necessidade possa ser satisfeita.

Sendo um trabalho social como os outros, a prática em saúde e a prática médica, em particular, tem, no entanto, algumas características distintivas como trabalho. Dentre elas, uma das mais evidentes é que este trabalho acontece em uma situação de interação intersubjetiva imediata, dada pelo fato de que o seu objeto de trabalho é um ser humano, que reconhece o seu problema como de saúde e procura a reparação na atuação profissional médica. A interação entre estes sujeitos é, portanto, parte intrínseca deste trabalho. E, mesmo existindo como dimensão do trabalho humano em geral, detém peculiaridades próprias como trabalho, por ser médico e por ser prestador de serviço.

Na modernidade, a prática médica assumiu as características de medicina científica que conhecemos hoje e vem sendo oferecida massivamente para toda a população. A medicina moderna é uma medicina social FOUCAULT (1984), porque pretende atuar sobre um coletivo extensivo de corpos. $\mathrm{O}$ modo como esta atuação se dá foi designado sob o conceito de medicalização FOUCAULT (1984), DONNANGELO (1979), ILLICH (1975), do qual trataremos mais adiante.

Embora atuando sobre cada um, o monopólio profissional da prática e seu oferecimento contínuo e extensivo fazem com que seus resultados tenham caráter social, porque atuam sobre populações, reatualizando as formas e normas do bem viver. Apesar deste caráter, a prática médica persiste, até os dias de hoje, estruturada nuclearmente em pequenas unidades de produção, a consulta médica, com uma relativa autonomia técnica de cada profissional sob os resultados de seu trabalho. Nas últimas décadas, entretanto, esta prática passou por diversas mudanças, no sentido de uma rápida incorporação tecnológica e uma profunda 
especialização e divisão em trabalhos parcelares, tanto horizontalmente (criando-se múltiplas especialidades médicas), como verticalmente (com a passagem de tarefas menos complexas tecnologicamente a trabalhadores com menor especialização). SCHRAIBER $(1993 ; 1997)$ nos mostra o processo de rearranjo dos princípios de autonomia profissional neste contexto, e como os médicos conseguiram manter sob controle o núcleo técnico do trabalho, mesmo trabalhando agora não mais como produtores isolados, mas como profissionais de grandes organizações de cuidado à saúde. Isto se deu pela perda de parte das condições que garantiam a autonomia tradicional (como o assalariamento), e, ao mesmo tempo, a manutenção do controle intelectual do núcleo duro da prática: o processo de diagnóstico e terapêutica, centro do processo de trabalho em saúde. A esta forma de medicina contemporânea, de diagnóstico "armado", crescente especialização e organização complexa chamaremos aqui, seguindo Schraiber, de medicina tecnológica. Na medicina tecnológica, entretanto, a autonomia é reatualizada, não sem perdas. Assim, os profissionais se confundem cada vez mais com as instituições onde atuam (médico de tal ou qual hospital, ou do convênio), e, ao mesmo tempo, criam-se estereótipos de coletivos populacionais de clientes (clientes de serviço público, ou do consultório particular, por exemplo)

Estudando a prática profissional, a autora nos mostra como o saber profissional e a técnica que ele opera tem uma dupla ordem (técnica-tecnológica e técnica-arte): por um lado, o saber funda-se no conhecimento científico biomédico, transformado em saber tecnológico em livros textos que prescrevem a atuação para cada situação da prática - técnica-tecnológica. Por outro, os profissionais valem-se de sua experiência com este mesmo saber, seus erros e acertos, e as peculiaridades de cada sujeito-doente trabalhado, para atualizar e criticar este saber de base científica-técnica-arte. Esta dupla ordem não significa uma cisão na prática técnica, como se houvesse um momento da prática que é arte e outro, tecnologia, e só nos serve para propósitos analíticos. Embora a medicina tecnológica tenda a obscurecer 
sua dimensão de "arte" e busque afirmar-se como pura aplicação neutra da ciência, SCHRAIBER (1997) nos mostra a impossibilidade da extinção da dimensão interativa no trabalho em saúde, nos moldes como está colocado hoje. A desvalorização atual da dimensão de arte da prática está na origem da atual crise que ela detecta na prática contemporânea, que qualifica como crise de confiança.

De acordo com este referencial, abordaremos neste trabalho os problemas concernentes aos serviços não apenas em função dos cuidados ou orientações objetivamente produzidos, mas também simultaneamente do modo interativo de fazê-lo. Este tem sido o ponto de vista mais atual também nos estudos do campo do planejamento em saúde (GALLO, 1995, RIVERA, 1995), o que leva a ultrapassar o usual enfoque da produção assistencial como problemática exclusiva da gerência dos serviços. Tais enfoques privilegiaram um olhar mais estrutural acerca dos serviços, gerando a compreensão das práticas e da qualidade dos cuidados como conseqüência da estrutura de sua organização produtiva. Sem negar a importância da organização, buscaremos valorizá-la sob outro olhar (D’OLIVEIRA; SCHRAIBER, 1999). Os serviços ganham abordagem processual e passam a ser vistos como dinâmica de relações interativas, que se dão entre profissionais e entre estes e os usuários, no momento em que se encontram todos dispostos em exercício (aplicação/mútua troca) dos conhecimentos científicos, técnicos e práticos de uns (profissionais de saúde) e das informações científicas adquiridas e saberes práticos de outros (usuários dos serviços).

No que tange aos serviços, temos, assim, dois tipos de problemas que, vistos pela dinâmica interativa, estamos tratando em conjunto: de um lado, a organização da produção e a arquitetura dos trabalhos, tal como usualmente pensamos os programas de saúde, por exemplo; e de outro, as ações de intervenção técnica, que são processos de trabalho realizadores daquela organização e, nisto, articuladores 
das necessidades e demandas em saúde, dos saberes e das técnicas, a fim de alcançarem determinados resultados, o que também faz parte dos programas de saúde. Tal como apresentado como relação usuárias-serviço, a dimensão organizativa somente está dada como problemática interiorizada no plano técnico, razão pela qual, quando se leva em conta agir no sentido comunicacional, também quer dizer que há, na organização vigente, canais possíveis de expressão e escuta de demandas.

É nesse sentido que uma crítica à qualidade assistencial a demandas que são trazidas pelas mulheres - neste caso, em particular, relativamente a questões de violência e gênero - em nossa abordagem não tratará da dimensão mais estrutural da assistência, mas passa a se preocupar com a interação entre indivíduos, que se dá pela ação técnica, recortando a própria organização pelo plano das relações entre os profissionais e os usuários dos serviços. É desta perspectiva que deriva a possibilidade de pensarmos os serviços não apenas por sua coerência estrutural, mas por elementos de seu movimento e mudança.

De igual modo, na intervenção técnica, se o processo de trabalho é tomado como ação estruturada pela organização dos serviços em suas determinações técnico-sociais relativas aos objetivos e resultados pressupostos para a intervenção (MENDES-GONÇALVES, 1994), será analisando as relações de seu agente (os profissionais da saúde) com o processo da intervenção mediada pela interação com as usuárias que interpretaremos o uso concreto do saber médico e sanitário (no caso, as normas técnicas do PAISM em operação no cotidiano dos serviços). Assim, buscaremos não só apreender as transformações dos conhecimentos e normas, e a criatividade de sujeito trabalhador, mas a própria interatividade (mútuas trocas) dos saberes médicos ou técnico-científicos com os saberes práticos. São tais perspectivas que, para nós, mesmo focando a problemática do ponto de vista dos serviços, revelarão a interação entre os sujeitos presentes ao ato técnico. 
Essas interações serão abordadas pelos diálogos e ações que se dão no interior do ato técnico entre os usuários e os profissionais em relação. Assim, vamos nos aproximar dos atos do trabalho médico, que é, simultaneamente, produção e consumo do serviço, pelas falas e suas trocas dialógicas ocorridas no transcorrer daquele ato e também pelas ações efetivamente realizadas, como as condutas tomadas, registros realizados, expressões, acolhimentos e recusas observados.

Ainda que estejamos lidando diretamente com o jogo interativo, sabemos que há outras questões perpassando tal jogo, da ordem tanto da produção dos trabalhos quanto da realização do consumo, como, por exemplo, acesso aos serviços e às tecnologias, recepção, possibilidades de uso reiterado ou continuidades assistenciais, entre outras. Estas se cruzam com questões, por exemplo, da realização, por parte das usuárias, de respostas às suas necessidades, do que deriva sua satisfação quanto aos serviços. Por parte dos profissionais, aquelas questões se cruzam com as da realização do exercício de boas práticas, definindo os padrões com que se trabalha. É desse conjunto de delimitações que surge o modo pelo qual se estabelecerão relações dadas entre as mulheres e os profissionais de saúde, mediadas por outras articulações, tais como: entre os profissionais e seus saberes; entre os profissionais e suas condições de trabalho; entre as usuárias e suas vidas privadas; entre as usuárias e o serviço organizado para dadas ofertas de produção assistencial; entre usuárias e suas expectativas perante ao serviço, tanto de uso, quanto de resolução de problemas - interpretados estes como necessidades de saúde. Com isto queremos dizer que a medicalização do social, a coisificação do doente como objeto da intervenção técnica e do trabalho, a elitização de profissionais e seus interesses corporativos, serão, com base neste olhar, problemáticas dos serviços e de sua organização produtiva que, no entanto, estarão expressas pelo diálogo técnico-assistencial que ali se trava. 
Partindo teoricamente, como já exposto, da noção de que o jogo das falas representa a interatividade entre estes diferentes sujeitos sociais, e ademais, partindo da aproximação do trabalho como, também, interação, buscaremos, no contexto específico de serviço de saúde, captar de que modo esses sujeitos, ao produzirem distintas falas, valendo-se de seus saberes, suas experiências de vida e de suas situações institucionais, colocam-se quanto ao feminino na relação de gênero, e algumas de suas questões mais relevantes na interface com a saúde: o corpo, a maternidade e a sexualidade. Isto porque a situação de violência nas relações de gênero possuem exatamente este substrato em sua geração.

Entenderemos que este 'colocar-se' de usuárias e profissionais encontra-se num contexto de uma ação sempre estratégica - que é a do trabalho - pois um dado resultado é buscado nesta ação, que apresenta, também, sempre uma face interativa. A extensão e profundidade desta interação variarão a depender da organização e objetivos de cada atividade assistencial e da relação intersubjetiva estabelecida pelos sujeitos presentes.

Quando a interação tiver como fim a comunicação com o sujeito que se apresenta na relação, ela se aproxima do pólo interação comunicacional. Nesta forma de interação, os sujeitos compartilham expectativas de validade e tem como objetivo a compreensão do outro e a relação em si, gerando poder. Quando a interação for um meio para a obtenção de fins individuais, além ou aquém da relação propriamente dita com o outro, ela será entendida como aproximando-se do pólo interação estratégica, obstaculizando a comunicação e podendo gerar violência, mas ao mesmo tempo preservando a possibilidade crítica, a depender da posição dos sujeitos em relação. Quando esta interação estratégica romper com um dos sujeitos e deixar de ser interação, tornando-se subjugação do outro e impedimento de sua possibilidade de expressão, pela sua redução à condição de objeto, estaremos falando de violência. 
Ao mesmo tempo em que o discurso competente falado nos serviços estabelece quem pode falar o que e onde, concretizando a interação estratégica e podendo silenciar as possibilidades de fala da usuária que não o domina, favorecendo a violência, a própria existência de canais de fala constituídos abre a possibilidade de relação comunicacional e a emergência de outros discursos, nem tão autorizados, discursos que subvertem as regras do saber competente e falam da experiência do mundo da vida, convidando à reflexão e ao debate, e gerando poder legítimo. Neste caso surgem espaços de potenciais emancipações e fortalecimentos de cada qual como sujeito - situação esta que entenderemos como de 'empoderamento' da intersubjetividade, ou de comunicação: o oposto da violência. Estes espaços, propostos na organização do trabalho do PAISM serão privilegiados na análise.

É interessante destacar que parte considerável da interatividade neste estudo ancora-se basicamente em uma situação singular e instigante: a relação mulheres-mulheres, pois a maioria dos profissionais da saúde são, igualmente, mulheres. Estas, no entanto, são sujeitos também reprodutores de uma ordem e poder de grande dominância na sociedade, o poder médico. Situam-se, por isto, no centro de uma tensão ou conflito ímpar como sujeitos: realizar, no cotidiano, pólos distintos e contraditórios de identidades.

Aqui está também a potencialidade do referencial de gênero para o estudo dos serviços, trazendo questões que não podem ser vistas ou refletidas por outro olhar senão este. Sua grande vantagem será permitir pensar novas tecnologias assistenciais para aprimorar a perspectiva emancipatória pretendida pelo movimento social e pelas proposições técnico-científicas que sustentam o Programa de Atenção Integral à Saúde da Mulher - (PAISM). Para além do próprio estudo da violência nas relações de gênero, queremos apontar para a fecundidade científica, tecnológica e ético-política da articulação dessa perspectiva de gênero 
com o estudo das práticas e dos serviços, estudo que tem sido temática tradicional do campo da Saúde Coletiva, mas ainda pouco trabalhado sob o olhar de gênero.

Além disso, é por meio do contexto interativo que apreendemos melhor o mencionado conflito identitário dos profissionais, iluminando, em especial, a tradicional questão da medicalização e da elitização dos trabalhadores da saúde diante da população, mostrando situações em que a tensão de identidade pode vir a assumir características de um verdadeiro conflito moral (SCHRAIBER, 1997). A resolução deste conflito penderá, ou não, para um posicionamento eticamente perfilado com a busca de emancipação de gênero, em que o " colocar-se" diante de um problema como o da violência oferece-se à reflexão como um caso exemplar. Isto porque o imperativo de optar ética e politicamente dá-se, aqui, em situação extremamente dramática: a violência. É neste campo do trágico (SCHRAIBER, 19973) que observamos o conflito que se estabelece, em que a necessidade de optar ganha, por parte dos profissionais, uma grande premência, daí termos nos valido da noção de conflito moral (SCHRAIBER, 1997). A opção, a nosso ver, está na dependência da organização do serviço e da prática assistencial decorrente, tanto quanto da modalidade interativa buscada no trabalho. Nossas observações mostram que o posicionamento perfilado com a emancipação de gênero - em que a opção se dá pela difícil escolha de uma identificação de sujeito com a condição mais 'frágil' ou socialmente dominada como a de sujeito feminino (mulher) - está relacionado com as finalidades de uma assistência 'integral', voltada para a emancipação feminina, tal como propõe, como exigência tecnológica, a própria estruturação do PAISM (D’OLIVEIRA, 1996).

${ }^{3}$ A noção de "trágico" relacionada ao conflito moral diz respeito à situação em que o profissional se vê diante do dilema de decidir em situações de características radicais, em que a decisão profissional se vê sem o amparo técnico ou científico, sendo necessário um apelo à ética e ao contexto prático cotidiano para resolver-se como tomada de decisão. 
A introdução do problema-violência na prática assistencial em saúde depende de encontrarmos o sentido tecnológico que este problema possa ter para aquele trabalho. Para tanto, é importante aprofundarmos a análise que faremos do conceito de medicalização, que vem expressando o movimento de incorporação de novos temas e aspectos da vida social ao trabalho, aspecto importante da medicina contemporânea. Vejamos com mais detalhes este conceito e as etapas do trabalho em saúde, que nos servirão de guia na análise do material encontrado, para buscar o sentido tecnológico do trabalho sobre problemas de saúde conexos ao problema violência. Assim, estudaremos o processo de trabalho em saúde como uma dimensão do processo medicalizador privilegiada em nosso estudo.

\subsection{Medicalização - a linguagem da doença}

Medicalização é um conceito bastante utilizado, que tem sua origem justamente na crítica ao monopólio do cuidado à saúde adquirido pela medicina científica (ILLICH, 1975). O conceito será tomado aqui, segundo a posterior apropriação de (DONNANGELO 1979), em dois sentidos. O primeiro deles, e talvez o mais utilizado, diz respeito à extensão da intervenção técnica das ações médico-sanitárias no âmbito da normatividade sócio vital. Corresponde à extensão de serviços assistenciais, extensão de tecnologias saneadoras do meio, extensão de disciplinas e aconselhamentos acerca de dietética, exercícios físicos, higiene individual, sexualidade, cuidado com os filhos, enfim, sobre o bem viver, além do socialmente normal ou patológico. A medicalização é, assim, processo a um tempo cultural, político e econômico, e diz respeito à rápida e crescente expansão do número de pessoas e de sofrimentos na vida de cada um, que são remetidos aos profissionais de saúde na busca da definição do patológico e de técnicas de restauração do normal e do bem viver. A mais importante e popular destas técnicas de combate ao sofrimento denominado como doença, além da mais lucrativa, é o consumo de medicamentos, o que muitas vezes acaba ocasionando 
uma redução do conceito de medicalização apenas ao aumento deste consumo. $\mathrm{O}$ aumento de consumo de medicamentos e exames diagnósticos é um lado extremamente importante, cultural e economicamente, do processo medicalizador, mas não esgota o sentido pretendido para a medicalização.

A segunda dimensão dessa complexa dinâmica medicalizadora corresponde ao fundante dessa extensão de cobertura. Ao explicar de certo modo e com certos referenciais a experiência vivida, o saber médico estatui-se como a melhor explicação, porque ancorada em um discurso de verdade: o discurso científico. Essa observação é de extrema relevância para nossa análise, pela complexidade da situação criada na extensão de serviços, já que toda forma de produção de serviços, longe de ser ingênua "resposta à demanda", é também instauradora de necessidades (SCHRAIBER et al 1996).

Os autores comentados mostram que não só o trabalho, por meio da reiteração de produtos socialmente úteis, retroalimenta as necessidades sociais a ele atinentes, como mostram que neste processo geram-se outras necessidades, produzidas na própria operação do trabalho.

Estas podem ser necessidades do próprio processo de trabalho, relativas quer aos instrumentos, quer às condições de trabalho, ou ainda de produção de conhecimentos, como novas necessidades de saúde para a sociedade em geral. Trata-se da medicalização, que é a expansão do corpo de competência da medicina também do ponto de vista do seu trabalho, e não só de seu saber ou de seu campo de normatividade ou do consumo de bens e serviços relativos à saúde. Nesta específica esfera do processo de trabalho, o processo medicalizador pode ser visto como circular, mas, para fins de análise, vamos dividi-lo em três momentos principais.

O primeiro deles pode ser localizado na vida social de alguém que carece; sente e percebe um sofrimento. Este carecimento humano, social, histórico, 
consciente e objetivável é uma necessidade social (HELLER, 1986). Alguns destes carecimentos são percebidos como necessidades sociais de saúde, o que é um primeiro momento da medicalização da violência. Será remetido aos serviços de saúde aquele sofrimento que tiver alguma forma consciente, objetivável, social e histórica de possibilidade de satisfação antevista nesta área. Estes sofrimentos são percebidos pelas pessoas como doenças sempre que implicarem impossibilidades de exercer sua vida cotidiana da forma esperada naquele contexto social. Assim, a doença é uma alteração sentida como obstáculo no "modo de andar a vida" do sujeito, que não consegue cumprir com as expectativas colocadas pela normatividade sóciovital (CANGUILHEM, 1992).

A interpretação de cada indivíduo para as formas possíveis de alívio de um sofrimento está, como vimos, relacionada à sua específica inserção social em determinada época histórica. A estrutura social vigente determina, até certo ponto, quais sofrimentos poderão ou deverão ser remetidos à saúde, a depender das formas de satisfação antevistas, que são aquelas produzidas em determinado momento histórico.

O saber biomédico tem o monopólio desta definição, ancorada no acúmulo de conhecimento científico que sustenta o seu saber técnico e lhe confere grande legitimidade e poder econômico e cultural na modernidade. Os sofrimentos considerados como passíveis de serem doença levam a um esquadrinhamento do corpo anatomopatológico daquele que sofre. É importante perceber que este corpo esquadrinhado não é mais o corpo físico do sujeito social, nem mesmo algo "natural", que existe antes do conhecimento e das técnicas que ele orienta. O próprio corpo anatomopatológico já é, claramente, uma construção do saber médico. Se a doença puder ser apreendida como alteração de regularidades deste corpo que pode ser visto, palpado, auscultado, ou traduzido em imagens do corpo ou exames de fragmentos de tecido corporal, ela pode ser enquadrada na nosografia como patologia e recebe uma proposta terapêutica. 
Ao procurar reconhecer seu sofrimento como doença e, portanto, buscar o aval profissional, o sujeito submete-se ao monopólio médico de legitimação e reparação do sofrimento da doença que sente. $\mathrm{O}$ indivíduo aceita, consciente ou inconscientemente, ser expropriado de seu juízo privado acerca das origens do seu sofrimento e formas de amenizá-lo, e o entrega a outras mãos que, ancoradas em um saber científico que ele desconhece, mas legitima, vão dizer a ele o que é verdadeiramente normal, o que é verdadeiramente doença, e o que ele deve fazer para restaurar o normal no seu corpo e consequentemente na sua vida. É o discurso competente da medicina, daí por diante, que vai dar sentido (ou não) ao sofrimento sentido por ele. A aceitação desta expropriação de seu juízo acerca da experiência de adoecimento por parte dos indivíduos que adoecem é explicada como validação da autoridade científica como cultural (STARR, 1982), ou como transmutação de sua legitimidade em autoridade moral (SCHRAIBER, 1997). De qualquer forma, não sem tensões, a autoridade técnica assume maior valor como explicação do vivido.

Para obter a promessa de alívio oferecida pela medicina, no entanto, há que traduzir o sofrimento na linguagem da medicalização, o que chamaremos da linguagem da doença. Esta linguagem é composta por sintomas físicos, como dores, tonturas, mal-estar, disfunções orgânicas, traumas físicos; ou de sintomas psicológicos, como angústia, medo, tristeza, ansiedade, depressão, insônia; e tem termos próprios, lugar, tempo e regras de enunciação. Traduzido e reduzido nesta linguagem, o sofrimento cotidiano tem uma proposta e uma promessa de reparação oferecida pelos serviços de saúde: a cura, a ausência de dor, a saúde; com sorte, a felicidade. Para todos os sintomas listados, e mais alguns, a prática assistencial em saúde promete pelo menos alívio. Esta promessa é massiva: está na TV, nos jornais, nas escolas, nas famílias. Todos nós, seres históricos do nosso tempo, recorreremos a ela em uma variedade de situações em que não nos 
sentimos "normais". Todos nós já experienciamos situações em que estas promessas, ao menos em parte, são cumpridas.

Parece-nos que o sofrimento decorrente da violência doméstica percebido pelo sujeito tem na queixa mental ou física uma das (poucas) formas legitimadas de se expressar publicamente. Solicitar cuidado e alguma possibilidade de solução, ao ser remetido aos serviços de saúde, na forma de demanda que busca ser rotulada como doença, parece legítimo. Queremos afastar a idéia possível de que os sofrimentos advindos de problemas "sociais" e que nem sempre revelam substrato anatômico de lesão, seriam por isso invenção, exagero ou manipulação psicológica, ao passo que aquelas demandas que têm um substrato anatomopatológico claro seriam as verdadeiras doenças. Interessa-nos, justamente, uma percepção da doença mais ampla do que a da nosografia médica.

Assim, trabalharemos com a noção de que percebida uma dada situação como virtual, ou presentificada condição de adoecimento ou perda de saúde, tal situação será, visto que é vista como problema atinente às práticas de saúde, uma necessidade de saúde legitimamente em razão da medicalização introjetada na cultura, ainda que, nem sempre, genuinamente para o sujeito portador da necessidade. É claro que tal leitura das necessidades e da própria medicalização não se dá sem conflito com aquela do saber médico.

Assim, da perspectiva da nossa interpretação quanto à geração de necessidades de saúde a partir de carecimentos (sofrimentos), não nos importará se os sofrimentos apresentados são ou não verdadeiramente doenças, conforme definido pela medicina, mas sim aquilo que significam para seus portadores. Já para entendermos a ação profissional, será central considerarmos esta diferença de percepção e conhecimento medicalizador, como forma de lidar com o problema trazido como necessidade de saúde, e o trabalho realizado sobre ele. Também não nos importa a clássica divisão entre saúde física e mental para a geração da 
necessidade de saúde, mas sim as práticas assistenciais diversas dirigidas àqueles sofrimentos, e os sentidos distintos que têm para profissionais e usuárias. Para nós, todo sofrimento dirigido aos serviços como doença é legítimo, porque autenticamente percebido pelo sujeito que o porta como uma alteração do normal vivido.

Em outros termos, a linguagem da doença, apesar de difundida na sociedade, possui um enorme código oculto que é de monopólio profissional dos médicos, em primeiro lugar, e dos demais agentes de saúde, em segundo. Isto implica que o sujeito que sofre pode tentar falar esta linguagem, mas nunca poderá dominá-la, tendo que submeter-se àqueles que são competentes para isto. Mas, ao esboçar a linguagem da medicalização, o sujeito já está tacitamente aceitando suas condições, ainda que possa buscar fins diversos que aqueles previstos pelas instituições para o seu trabalho. Ao perceber seu sofrimento como possível doença, este sujeito buscará expressá-lo nos serviços de saúde, através dos canais de expressão que encontra na instituição para a qual se dirige. Estes canais de expressão são formas de organização institucional e ações de sujeitos profissionais que oferecem determinadas oportunidades de fala. Portanto, a possibilidade de emergência do problema será compreendida como uma resultante do reconhecimento e necessidade de expressão do sujeito que sofre (em nosso caso, mulheres usuárias de um dado serviço), combinada com os canais de comunicação e oportunidades de fala abertos pelo serviço.

A suposta doença percebida não será, portanto, necessariamente qualificada e acolhida no serviço, e aqui começa o segundo momento da medicalização sob a ótica do processo de trabalho. Para que seja reconhecida como necessidade de saúde do ponto de vista biomédico, é preciso que os profissionais possam encontrar, na demanda recebida, um objeto de trabalho e potencial produto antevisto, que seja manipulável pelos saberes e instrumentos disponíveis, tornando possível o estabelecimento de um plano de trabalho em termos de pesquisa 
diagnóstica e indicação terapêutica que permita antever o retorno à normalidade. A clínica em medicina possui um arsenal com um extenso interrogatório, exame físico e exames laboratoriais para buscar decifrar anormalidades que sejam passíveis de enquadramento dentro de um elenco de doenças conhecidas. A clínica psicológica possui também arsenais hermenêuticos, variados entre si, para buscar seu objeto de trabalho, que acaba sendo bem mais ampliado, por ser também de limites mais imprecisos 4 .

Nem sempre o sofrimento percebido como doença pelo sujeito que sofre pode ser percebido pelos profissionais de saúde como passível de reconstrução na nosografia médica e reconstruído como doença do ponto de vista da técnica profissional, permitindo encontrar uma solução ou resposta na intervenção médico-sanitária. Esta segunda etapa da medicalização regula aquelas demandas ou queixas que podem ser expressas ou enunciadas como patologias, e aquelas que serão descartadas. Quanto à esfera psicológica da intervenção, se há particularidades relativamente ao saber clínico da medicina, há também, por seu lado, alguns enquadramentos próprios necessários à tecnologia assistencial correlata. Por lidar com o sofrimento subjetivo individual, e ter um substrato científico menos solidamente ancorado nas ciências biológicas e físicas, o sofrimento pode mais facilmente ser acolhido como doença mental, mas esta acaba por ser mais estigmatizada e autorizar menos privilégios sociais ao papel de doente (FREIDSON, 1978) e até algumas sanções àqueles que a sofrem.

Esta segunda "etapa" da medicalização - a profissional - regula aquelas demandas ou queixas que podem ser enunciadas como risco de doenças ou patologias atuais e aquelas que serão descartadas. As queixas sem referência nesta codificação são percebidas nos serviços de saúde como dissimulação, histeria, distúrbio neuro-vegetativo, somatização e outros rótulos que recebem com

${ }^{4}$ Recuperando o paralelo que fizemos com as DDMs, é interessante reconhecer que estas também têm critérios bem estritos para a aceitação ou recusa da " queixa": a lei. 
freqüência as pacientes. Tanto as patologias físicas como as mentais, entretanto, não envolvem, em tese, responsabilização do sujeito doente. O papel de doente culturalmente construído implica que a pessoa não tem responsabilidade por sua doença, a não ser a de procurar ajuda técnica especializada e procurar tratar-se e seguir corretamente as indicações recebidas (FREIDSON, 1978), e é isto que fazem as mulheres observadas por nós.

A violência como um problema específico não tem possibilidade diagnóstica em nenhuma das duas nosografias (médica ou psicológica) e, portanto, também não há antevisão de resultado da intervenção, ou alternativas previsíveis, quer na prática clínica, quer na psicoterápica. O problema-violência ou o sofrimento que gera a situação de violência vivida terá alguma chance de ser acolhido apenas se apresentar possibilidade de ser enquadrado como patologia física ou mental, atual ou futura. E é assim, como veremos, que tal sofrimento é remetido aos serviços de saúde, e tem possibilidade de acolhimento por ele, ainda que, algumas vezes, este modo de expressão revele-se pouco útil para a intervenção almejada pelas mulheres que buscam tal assistência no sentido de alcançar uma terapêutica eficaz do ponto de vista profissional, e também para a compreensão dos profissionais que as atendem.

As demandas acolhidas sofrerão, então, o terceiro momento da medicalização, o plano da intervenção propriamente dita, na qual, feito um diagnóstico e uma decorrente proposta reparadora, esta desdobra-se em ações e comportamentos específicos. Assim, o projeto de trabalho recomendado se cumpre, ou não, na vida social do sujeito alvo da intervenção. Ele deve agora ser adaptado às características peculiares de cada indivíduo, coisa que não ocorre necessariamente no processo do diagnóstico, que trabalha com leis gerais sobre um corpo anatomo-patológico. A intervenção, muitas vezes, está baseada no consumo de medicamentos, o que encerra o ciclo, desde que seja possível e efetivo o cumprimento da receita recebida, o que também articula a medicina ao processo 
social. A adequação da proposta de intervenção e sua efetiva realização satisfaz (ou não) a necessidade social, e produz, neste processo, novas necessidades, recriadas a partir desta experiência, que orientará a satisfação de carecimentos futuros, reiterando o processo. A resposta alcançada será concebida, portanto, como a proposta de intervenção enunciada pelo serviço em combinação com a sua efetivação pelo sujeito em sua vida social.

A medicina e as práticas de saúde são técnicas moral-dependentes (SCHRAIBER, 1993), e a interação estabelecida com aquele que se sente doente é uma faceta importante da técnica. Isto porque a autoridade técnica traveste-se de autoridade moral, e também porque é moral a conquista da confiança, substrato básico para a possibilidade do relato da anamnese em profundidade. Para o problema-violência, o trabalho em saúde tem instrumentos precários para fornecer a prometida reparação, já que sua técnica é baseada na manipulação e restauração de constantes do corpo biológico orientadas pela ciência. Pode, no máximo, reduzir a dor, ou os sintomas, mas não pode atuar sobre a situação que os origina, já que se encontra desconectado da rede intersetorial que, quando existente, poderia apoiar a construção de um caminho de resolução . Localiza-se aí, a nosso ver, parte substantiva das origens da reiteração interminável das queixas referidas aos serviços de saúde, mas não resolvidas, que são descritas pela literatura como um uso aumentado de serviços para estas mulheres.

No entanto, se no plano tecnológico propriamente dito, o problema violência encontra tais limites, produzindo importantes conflitos interativos entre usuárias e profissionais, do ponto de vista ético a questão pode encontrar outros enquadres, os quais podem vir a produzir sentido tecnológico para a inter-relação. É assim, na perspectiva da interação comunicacional, que imaginamos que o problema possa ser abordado e encontrar ação emancipadora. Mas isto mostrou-se raro e difícil em nossas observações, como veremos, entre outros motivos pelas dificuldades próprias da organização contemporânea do trabalho em saúde. 
Desde o momento do diagnóstico até o estabelecimento da terapêutica ou cuidado correspondente, o processo de trabalho pode ser mais ou menos dialogado, as decisões mais ou menos compartilhadas e aspectos do problema considerados ou esquecidos, a depender da relação que se estabeleça entre os dois (ou mais) sujeitos presentes. É certo que, se o conhecimento científico da medicina instrui intervenções eficazes, que, no limite, independem da vontade do sujeito doente, a interação comunicacional é sempre potencialmente parte do ato médico, podendo até, em alguns casos (como nos parece ser o da violência), articular-se com sua dimensão de técnica-tecnológica em posição de superioridade. A violência contra a mulher explicita e solicita, portanto, a discussão das relações de poder no interior dos serviços, tanto do poder entre homens e mulheres como o poder entre usuárias e funcionários (as), conforme preconizava o PAISM. O sentido ético destas relações assume aqui, portanto, fundamental importância, e determina até a possibilidade de alcance de resultados esperados, como o alívio do sofrimento enfrentado por aquele que se sente doente.

Em síntese, partimos da tese genérica de que a busca de serviços de saúde é uma forma social e historicamente estabelecida de expressar o sofrimento crônico decorrente de situações de violência, por meio da queixa de mulheres que não se sentem normais, o que explicaria o alto consumo de serviços de saúde relatado na bibliografia, por motivos, muitas vezes, não especificamente relacionados com a violência, mas tampouco com quadros mórbidos bem definidos. Interpretando o seu sofrimento como possível doença, percebendo os sinais do corpo por meio desta linguagem, a mulher procuraria um sentido, uma reparação e uma retomada da interação no núcleo doméstico como doente, em uma tentativa de retomada da interação comunicacional no âmbito doméstico e resposta ao problema. Esta seria uma ação de sujeito, movimento ativo de dispor-se em relação.

O papel de doente pode significar empoderamento para sujeitos em situação de poder extremamente desfavorável, por ensejar cuidado e legitimar as 
dificuldades percebidas pela pessoa em manter suas atividades e responsabilidades habituais. Sentir-se doente é exatamente não se sentir capaz de cumprir todas as funções socialmente esperadas para aquele sujeito, afastar-se do normal. O uso dos serviços de saúde e o recebimento de cuidado e atenção para a reparação da queixa é um direito legítimo daquele que padece de uma possível doença, e recorrer a ele é um dever do doente. Além disto, como já abordado, a doença não é, por definição, responsabilidade daquele que a sofre, estando fora de seu alcance curar-se (FREIDSON, 1978). Buscar o serviço e a assistência é, portanto, direito social e dever moral. O resultado esperado pelas mulheres deste exercício de direito será a retomada da interação nas relações privadas pois, tal qual o recurso à polícia e à lei, autorizará a mulher a outro patamar de negociação com seu(s) agressore(s). A necessidade de "cuidados" (médicos e também de familiares) tornaria legítimo reivindicar outra forma de relação com ele(s).

No entanto, ao falarem a linguagem da doença, que não dá expressão plena ao sofrimento vivenciado, mulheres e profissionais interagem obstruindo a possibilidade de comunicação livre, omitindo a violência e buscando a reparação para o sofrimento causado por ela em termos exclusivamente centrados no recorte biomédico, ou o mais próximo dele, por meio de uma linguagem que a usuária "empresta", mas não pode dominar. Esta estratégia pode por isto ter efeitos inesperados. Ao buscar legitimar aquilo que percebe como transgressão da normatividade sócio-vital como doença, a mulher pode ser desqualificada pelo saber profissional, que não tem olhos nem palavras para aquilo que não está registrado no corpo. Se o sofrimento não for acolhido na dimensão interativa como transgressão da vida boa que todos, em princípio, teriam direito a buscar, ele fica sem alternativa de expressão, e a violência nas relações de gênero tenderá a ser reposta como "normal". Se, entretanto, a violência puder emergir direta e explicitamente como questão, ela só poderá ser acolhida pelo diálogo e discussão de valores acerca da vida boa e justa e dos caminhos que levam a ela, já que não 
pode encaixar-se no conceito de doença tal como compreendido pela biomedicina. Esta possibilidade, entretanto, tem dificuldade de efetivar-se quando o processo medicalizador está presente.

Com isto, o que pode representar um recurso de empoderamento de um lado (vida doméstica), resulta em posterior perda relacional e interativa de outro (na assistência). Entender melhor e qualificar tal perda nos permitirá pensar elementos instrumentais e comunicacionais que restabeleçam formas mais acolhedoras e produtivas de interação nestes casos, posto que, de nosso ponto de vista, cabe ao serviço levar em conta o sofrimento que solicita solução, ainda que, por sua competência específica, seja sempre uma solução bastante parcial.

Que espaço tem esta discussão nos serviços de saúde? Qual o seu sentido tecnológico? Quais suas conseqüências na vida das pessoas e em suas relações de intimidade? São perguntas que levaremos ao analisar o material empírico coletado.

Passemos agora à apresentação dos resultados encontrados no trabalho de campo. Vamos, a princípio, apresentar algumas de nossas personagens, que expressaram situações de violência observada diretamente ou registrada pelos profissionais em atendimento, acompanhadas do registro em prontuário para cada uma delas.

Depois, analisaremos o processo que acontece nos serviços de saúde: as observações realizadas; a análise dos registros em prontuários e o uso de serviços; e a fala profissional e das usuárias sobre violência, saúde e assistência à saúde. 
6. As histórias de vida:

\section{Apresentando as personagens}

É em virtude desta teia preexistente de relações humanas, com suas inúmeras vontades e intenções conflitantes, que a ação quase sempre deixa de alcançar seu objetivo; mas é também graças a este meio, onde somente a ação é real, que ela produz histórias, intencionalmente ou não com a mesma naturalidade com que a fabricação produz coisas tangíveis. (...) Embora todos comecem a vida inserindo-se no mundo humano através do discurso e da ação, ninguém é autor ou criador da história de sua própria vida. Alguém a iniciou e dela é o sujeito, na dupla acepção da palavra, mas ninguém é seu autor.

Hannah Arendt, 1995:197 
Toda a mulher quer ser amada

Toda a mulher quer ser feliz

Toda a mulher se faz de coitada

Toda a mulher... é meio Leila Diniz

Rita lee

P - $\quad$ Então, tem muitas teorias mas...

Cláudia - ...Mas,

P - $\quad$...Eu quero saber da pessoa. Então, por isso eu tenho que fazer as entrevistas; porque eu quero saber das pessoas.

Cláudia - Já que... a vida real.

P- $\quad$ A vida real.

Cláudia - Quer dizer, tudo é de uma vida real, nada se cria, tudo se copia...

P - Isso.

Cláudia - Tudo sempre existiu, né? (Entrevista, Usuária)

As mulheres entrevistadas relatam cotidianos domésticos conturbados desde a infância, estendendo-se, algumas vezes, à vida dos pais e familiares, indicando uma densa rede preexistente de relações humanas instituidora de longa tradição. Pode-se perceber nestas histórias as dificuldades concretas que a "condição de gênero" traz para a vida de cada mulher e as várias estratégias adotadas para a afirmação da vontade e de valores como respeito e justiça. As entrevistas foram importantes para compreendermos melhor a malha estrutural de relações que "enreda" a estas mulheres e homens nas relações de gênero e engendra as condições de emergência de situações de violência contra a mulher.

Entrevistamos cinco mulheres casadas, todas vivendo situações de violência conjugal na época da entrevista, detectadas por observação direta ou registro em 
prontuário: Rosana, 30 anos, Claudia, 59 anos, Elza, 26 anos, Carla, 37 anos e Marluce, 39 anos. Elas têm coincidentemente a mesma escolaridade - 4 anos -, poucos filhos e pertencem às camadas populares.

Apresentamos aqui suas histórias, mostrando um pouco da rede de relações sociais e violência e suas raízes nas normas sociais acerca de gênero, sexualidade e reprodução, para mostrar a força da tradição social, cultural e econômica que sustenta estas situações. Buscamos destacar as reações e estratégias das mulheres para lidar com as situações em que vivem. As mulheres estudadas são percebidas, assim, como sujeitos, na dupla acepção da palavra (ARENDT, 1995), ou seja, sujeitas (ou submetidas) à sua época histórica e sujeitas ativas que buscam (na medida do possível) transformar seus destinos, sujeitos que resistem ou combatem e assim refazem uma (nova) tradição. Isto porque, criadas em um contexto de relações de gênero bastante inflexível, convivem com a revolução trazida pelo movimento de mulheres e com o questionamento destas relações, que está colocado por seus desdobramentos atuais. Ouvem no rádio, na televisão, na escola e nas ruas que a mulher pode ou deve ter os mesmos direitos que os homens, algumas delas trabalham, enfim, são seres de nosso tempo, e lidam com as contradições contemporâneas.

Vamos apresentar agora as histórias de vida de Carla, Rosana, Marluce e Cláudia, contadas em depoimentos orais, seguidas dos registros encontrados em seus prontuários. $\mathrm{O}$ contraste entre a vida vivida e relatada e o registro filtrado pelos profissionais de saúde e fixado nos prontuários é nosso ponto de partida. $\mathrm{O}$ processo que transforma a vida em registro de diagnósticos e condutas é exatamente o que nos move aqui, o processo de trabalho em saúde. Nos capítulos seguintes analisaremos, por meios da fala das mulheres e dos profissionais, e das observações de atividades e registros, como se opera este processo e seus significados sociais. 
Cada uma das mulheres apresentadas representa uma possibilidade de se perceber e agir na situação de violência. Começamos por Carla e Rosana, que têm uma postura mais vitimizada e atribuem seus contratempos predominantemente aos outros e às suas condições de vida. Sentem-se sujeitadas, mais do que sujeitos de sua própria vida, e percebem esta sujeição como injusta, pois sofrem e não têm acesso à vida boa e justa que imaginam mereceriam. Elas correspondem mais ao estereótipo que temos das mulheres em situação de violência, e assumem um papel passivo diante das contrariedades que se lhes apresentam, ainda que lutem para obter o que necessitam, como ter um filho ou trabalhar. Já Marluce e Cláudia têm posturas mais ativas, mas nem por isto conseguem romper a situação de violência. Marluce se define como rebelde, agride e não se conforma com a subordinação, reclama pelo que quer. Cláudia é a mais velha e a que tem a maior reflexão sobre a própria situação, e explica racionalmente sua opção de ter ficado no casamento apesar da violência. As duas fazem questão de se colocar como sujeitos de sua própria vida, e não admitem que o que lhes acontece possa ser resultado de outra coisa que a sua própria vontade. Não queremos com isto julgar ou estereotipar nossas personagens, mas apenas apresentar formas diversas de se perceber e agir na situação, e nela as formas mais ou menos ativas em que cada uma se coloca, que conformam formas também diversas de relação com o serviço de saúde. Todas são, pela experiência comum, "vítimas da violência"; todas atuam reconstruindo e construindo novas relações de poder e violência; mas umas se diferenciam das outras no modo como trabalham ou lidam com as situações de violência em que se encontram.

\subsection{Carla}

Carla tem 37 anos, casada há 18 anos, com um filho de 17. Carla e o marido acabaram de comprar um imóvel e estão se preparando para mudar da casa onde 
moram, que pertence ao pai de seu marido. Ela não trabalha fora, mas, às vezes, dá suas "escapadelas" para fazer uns bicos escondida do marido.

Carla é filha de mãe solteira, que se casou com outro homem quando ela tinha 6 ou 7 anos. Tinha um irmão e ambos foram assumidos pelo padrasto, que os registrou como filhos, mas Carla reclama muito do tratamento que recebeu dele. Era espancada e ouvia clandestinamente o comentário dos mais velhos de que isto se devia a não ser filha legítima do padrasto, o que nunca lhe foi claramente explicado. Tem grande mágoa da mãe, que segundo ela não a protegeu.

Ele não tinha paciência, qualquer coisinha era motivo dele espancar mesmo, não era bater, era espancar. (...) Foi daí que eu comecei a escutar coisas, ele faz isso porque ele não é o pai dela -, as minhas tias falavam, sabe, porque minha mãe mesmo sempre aceitou tudo que ele quis, eu sinto isso dela. Acho que pelo fato dele ter casado com ela, ter pegado os dois filhos, estar criando, ela aceitava tudo. Inclusive até hoje, tudo que ele fala, para ela ele é Deus.

A gente falava que ele fazia aquilo com a gente porque ele não era o nosso pai, sabe ...

A sensação de Carla nesta época é bastante eloqüente:

Uma sensação assim ... a casa, os quatro cantos, e eu bem pequena, me sentia minúscula. Muito pequena ... pelo fato dele fazer isso com a gente. Ah, eu sei que a gente ... eu principalmente sofri muito na mão dele, muito, muito, muito.

Carla ia mal na escola, segundo ela por muita pressão sobre ela, já que qualquer erro implicava punição física. Quando ficou menstruada, Carla levou uma surra sem compreender porque:

Eu fiquei mocinha de 9 para 10 anos de idade. Levei a maior surra nesse dia, sabe ... minha mãe nunca teve ... Eu aprendi praticamente com os outros, ainda bem que eu aprendi o certo, tem muita gente aí que aprende tudo ao contrário. Se eu tivesse uma filha mulher ela seria orientada completamente diferente do que eu fui. Porque a primeira vez que eu fiquei mocinha levei uma surra, a minha vizinha teve que entrar dentro de casa para minha mãe parar de me bater. O que é isso, né?

Minha avó(paterna) disse assim: É ... está vendo como ela não presta? Essa é do tipo de mulher que quando estiver menstruada sai com a bandeira vermelha mostrando para todo mundo - E eu nem sabia o que era aquilo, meu Deus. Daí a vizinha que conseguiu me tirar do banheiro, que foi me explicar o que era ... que todo mês eu ia ficar assim, até aí eu não sabia de nada, sabe. Apanhei sem saber o porquê. 
Para Carla, este tratamento foi totalmente equivocado. Sentiu-se injustiçada, e diz que se tivesse uma filha menina faria tudo diferente. Não se conforma de terem batido nela por uma coisa que ela nem compreendia o que era... Carla suspeita também de que o padrasto tenha tentado assediá-la sexualmente:

Eu acho, não sei, pode ser até que esteja pecando no que eu vou falar, mas ele (o padrasto) tinha segundas intenções comigo, eu sentia isso dele ... Teve uma vez que minha mãe saiu para ir costurar numa amiga dela e eu fiquei em casa. E eu fui tomar banho, a maçaneta da porta começou a mexer, e só estava eu e ele dentro de casa. Então, desde esse dia, desde aí ... eu já tinha um pouco de receio dele, entendeu.

Desta experiência de vida, Carla conclui tristemente:

Ah, sei lá eu ... nem falo nada, fico assim porque ... eu não sei ... eu não sei se é porque nunca fui tratada como gente, como ser humano, eu sinto isso, da parte do meu pai e da minha mãe ...

Então, a única coisa que eu quero é ser tratada como gente, como ser humano (chora) ... sabe, acho que meu pai me reprimiu de muita coisa ...

Carla namorou alguns rapazes, sempre mentindo que ia até a igreja (ela tinha que namorar dentro de casa, na presença dos pais), até que se casou com o atual marido. Segundo ela, o casamento foi uma "fuga" da vida com o padrasto. Com três meses de casada, engravidou de seu único filho.

No começo (do casamento) foi tudo bom ... meu filho nasceu, foi ótimo, Depois de um certo tempo, quando o filho tinha uns 8 ou 9 anos de idade ... foi quando ele começou a beber... Daí ele bebia e ficava alegre. Depois ele começou a ficar agressivo, entendeu ... mas nunca chegou a ponto assim de me bater, sabe. Uma vez só que ele me deu um tapa ... mas até hoje eu tento lembrar quando foi o motivo daquele tapa e eu não lembro ... tem coisas na minha cabeça que vem assim e eu esqueço, é incrível ... não sei se é uma fuga. E a bebida... a bebida ... Aquilo ali é ruindade mesmo da parte dele, entendeu. Eu estava até pensando em chamar a polícia ... chamar a polícia e fazer ele passar uma noite (na DDM). Eu e meu filho não saímos de dentro de casa. Ir fazer ele parar na polícia. Teve dias de ele abrir a geladeira falar - é ... você deu até agora e não trouxe nada para dentro de casa? (...)

Mas do contrário, se ele está bem, sem beber, é uma pessoa até que legal, entendeu. Só que aquele jeito, não é de sair, é de ficar dentro de casa, isso e aquilo ... mas é uma pessoa que é boa assim, não tem o que falar.

O grande problema de Carla são as agressões verbais que o marido lhe dirige em alto tom, chamando-a de prostituta e assemelhados, e que toda a 
vizinhança ouve. Além disto, ele controla o seu horário e não quer que ela veja seus parentes ou se ausente de casa para trabalhar, porque tem muito ciúmes dela. Ela acha a acusação injusta, porque "não dá motivo" e fica bastante magoada com isto.

Sabe ... porque se eu tivesse um dia dado um motivo ... ele ter me pegado com alguém, ou traído ele, então ia ter que abaixar a cabeça e ficar quieta, sabe. Mas eu procuro fazer ... só que eu sou uma pessoa muito dada, e isso para ele acho que atrapalha. Eu me comunico com todo mundo, converso com todo mundo... Ele já é uma pessoa mais fechada, então ele já vê maldade em tudo. Se ele me vê conversando com o vizinho ... acho que não tem nada de mais ... Ele não quer mais que eu converse com a minha vizinha do lado. Ele quer que eu viva um mundo lá só com ele, sabe, com mais ninguém. E não é bem por aí. Acho que a gente tem que conversar com todo mundo. A gente está conversando às vezes até sobre a vida da gente mesmo ... Que nem ele fala ... está falando mal de mim ... eu falo - porque você deu motivo, ninguém vai falar de você sem ter motivo. Você dá motivo dos vizinhos falar. E os vizinhos mesmos falam que ... como que eu agüento ... sabe ... Eu sei que é difícil ... não é fácil ... mas ... o dia que eu tiver uma oportunidade, quem sabe ...

Nossas entrevistadas têm sempre que explicar porque permitem uma situação que lhes parece injusta. Porque ela permanece em uma situação que percebe como injusta, já que "não dá motivos" para ele desconfiar dela? Carla explica que está "imobilizada" por condições externas a ela: não teria como sustentar a ela e o filho só, o filho não aceita a separação, enfim, lhe faltam condições externas, "oportunidades". Imersas em uma cultura que prevê a obediência da mulher ao marido e a importância da exclusividade sexual devida a ele, estão, ao mesmo tempo, no mundo que exalta os direitos humanos e possibilidades equânimes para homens e mulheres. Entre estes dois extremos, Carla sente-se injustiçada, mas aceita a subordinação, na esperança de que um dia "as oportunidades" mudem. Enquanto isso, lança mão de transgressões que lhe ampliem as possibilidades de ação, mas que não rompam a relação conjugal.

Carla relata que seu marido não lhe permite trabalhar fora, e lhe diz que se precisar de dinheiro que peça para o seu filho, que teria obrigação de fornecê-lo. Ela argumenta na entrevista que não concorda, que não quer pedir dinheiro para o 
filho para tudo, e por isso busca estratégias de burlar a proibição. Estas estratégias são importantes, porque Carla usa este dinheiro para visitar sua irmã, por exemplo, coisa que o marido proíbe.

É ... ele deixa (o dinheiro) na minha mão, então eu procuro cortar certas coisas para poder ter as minhas, entendeu.

Eu falo para ele que paguei tanto e sendo que eu não paguei.

De vez em quando eu saio para fazer uma faxina ... escondido dele ... vou tensa, nervosa ... com medo dele me ligar para casa e eu não estar. E aí, o que eu vou falar?, Você entendeu?, Sempre é horrível!, horrível, nossa ... Viver mentindo, sendo que é uma coisa que você não está fazendo errada. (Carla, entrevista)

Carla acha errado mentir, mas submete-se a isto para poder aumentar sua possibilidade de autonomia. Para não mentir, seria preciso romper com a relação de subordinação e exigir condições mais simétricas de relação. Mas este rompimento é percebido por ela, de saída, como impossibilitado.

$\mathrm{Na}$ área da sexualidade, também há negociação, porque Carla não aceita algumas práticas sexuais propostas pelo marido, que a acusa de fria:

E ultimamente ele anda querendo sexo completamente diferente, que eu não aceito, gente ... sabe ... não vai na minha cabeça, não vai, não adianta. E daí começam as brigas ... Se ele vem hoje e pede e quer fazer tal coisa, eu falo que não ... - Se você quer buraco novo, você vai fazer na parede, falo bem assim... Então, não sei, não aceito. Que nem a outra psicóloga virou para mim e falou uma vez ah, mas ele é seu marido, tem que fazer o que ele quer ... --, mas não vai, não vai, sabe ... Eu não aceito ... não sei se é porque eu fui criada assim ...

Aí ele não dorme nem comigo, fala que eu não presto, que tudo que ele pede para mim eu não quero ... E eu falo para ele - não aceito isso ... você sabe muito bem , e eu acho que começou também ... eu fujo muito dele, por causa desse detalhe ... Ele não quer ter um relacionamento normal, sexo normal, e eu acho tão legal ter um sexo normal, para que ficar fazendo coisas ... sabe? Uma coisa diferente, tudo bem, mas fazer o que ele quer, que nem pòr atrás, eu não aceito, entendeu. Eu acho que ... não é por aí, não sei, não entra na minha cabeça isso. Não sinto prazer nenhum, é uma coisa que dóil, então como é que vai ser ... (Experimentei) e para nunca mais na minha vida ... ah, vai dormir ... Foi horrível!, que sensação, que tesão é esse que sente? Eu falo não e acabou e pronto

Por que eu tenho que aceitar um sexo completamente diferente? ... eu não peço coisas impossíveis para ele. Eu sei que isso é uma coisa normal entre um casal ... mas só que eu não aceito, gente ... Não vai, cada um tem a sua cabeça, cada um pensa de um jeito ... 
Ele acha que tem que fazer, que marido e mulher tem que ser prostituta na cama ... tem que ser amante. Mas eu acho que ele deveria de aceitar o meu jeito, eu não gosto, nunca aceitei ... são 20 anos que estou com ele, entendeu. E quando aceito, é contra a minha vontade, não vou negar. Sabe, você fazer uma coisa que está sendo contra a sua vontade?, só para agradar ele e satisfaze-lo? Eu não acho isso certo... Agora que nem o outro dia falei - para agradar você vou me submeter a fazer o que você quer, W.?, Jamais ... - eu falei - eu te dei uma vez para nunca mais ... que é isso! -. Então ... não aceito ...

No campo da sexualidade, parece que Carla sente-se mais legitimada para fazer sua vontade. Contesta a psicóloga que, segundo ela, teria lhe recomendado "a fazer o que ele quer", sente-se legítima e encontra condições para dizer não na maioria das vezes. Ao invés de mentir, aqui ela tem que enfrentar e fazer valer o seu jeito, ainda que algumas vezes sinta-se obrigada a ceder contra a sua vontade. Talvez seja mais possível para ela fazer valer aqui a sua vontade, porque ela está de acordo com o que se espera de uma boa esposa, enquanto trabalhar fora pode eventualmente ser visto como uma transgressão para uma boa esposa, ainda mais quando é contra a vontade do marido.

Porque ela se mantém nesta situação? Carla convive com a violência desde a infância, e devemos lembrar que ela diz que "nunca foi tratada como ser humano". Como ser humano, entretanto, ela reage e busca a liberdade. Mas em contingências extremamente desfavoráveis. Devemos lembrar que o seu marido é provedor, caseiro e "não tem o que falar" quando não bebe. Ela está atualmente comprando uma casa, conquista de vinte anos. Neste contexto, tem pena, esperança, justificase, ora pensa que tudo pode melhorar e hora acha que a tendência é só piorar:

Mas agora ele parou(beber), graças a Deus, ele parou, vamos ver ... Eu senti uma melhora, bastante. Mas é que a gente comprou a casa, mas eu ainda não estou consciente que eu comprei, entendeu. Eu comprei, eu paguei direitinho, inclusive dia 5 está para vir a escritura na mão da gente.

\section{(...)}

É que nem estava falando, se um dia meu filho casar, ele vai ter a vida dele ... eu arrumo uma casa de família e vou trabalhar ... eu vejo se consigo morar na casa de família ... eu moro, mas não quero nem dar o endereço, sabe ... Quando ele tiver a vida dele, ele casar ... aí eu saio de casa ... assim não tem condições. E uma, a tendência dele é piorar, entendeu, eu acho que a tendência dele é piorar. Se ele 
está com 44 anos e já é assim ...

E ao mesmo tempo tenho dó, porque ... eu tenho de largar ... ele tem um ciúmes de mim doentio ... até da minha sombra. E ele se entregar na bebida ou coisa parecida, então penso muito nas coisas, entendeu. Eu acho que por isso que eu sofro. Talvez se eu não pensasse tanto e agisse ... talvez eu não sofreria.

Perguntada sobre a freqüência deste problema para outras mulheres na região, ela comenta:

Em geral todas (as mulheres)... Meninas de Deus ... eu pensava ... que nem eu falei, só muda o endereço ... Ainda mais onde eu moro, gente, é incrível.

Eu pensava - meu Deus, como eu sofro ... -, Mas tem gente até pior do que eu até, sabe ... Que nem a moça que eu ando com ela todo dia, ela vive com o marido, o marido não dá nada dentro de casa, ela é cabeleireira, ela que mantém a casa, ele dorme num canto com o filho e ela com a filha em outro canto do quarto. Quer dizer, sempre tem, entendeu? E assim vai indo, fiquei sabendo esses dias. Achei que eles viviam maravilhosamente bem.

Carla elenca situações em que o "transtorno" nas relações de gênero é, a seu ver, ainda pior que o dela, para estabelecer o limite do que não aceitaria (no caso, um marido que não cumprisse com a função de provedor nem tivesse relações sexuais com ela). Todas as nossas entrevistadas fazem este movimento, procurando casos mais graves que justifiquem a sua própria situação, com base nos valores que dão para os papéis de homem, mulher e suas transgressões.

Ao ser perguntada, Carla a princípio não reconhece sua situação de vida como violência. Com a insistência da pergunta, termina por declarar que sim, chegando à conclusão, no momento da entrevista, de que a violência verbal do marido pode ser chamada por este nome, pois para ela isto é a morte:

P: me diga uma coisa, você está falando para a gente de um monte de situações, você acha que você sofreu violência na sua vida? Você chamaria essas coisas que você viveu de violência?

Carla : não, acho que não.

$P:$ nem quando você era criança, nem depois de grande ...

Carla: como assim você quer dizer?

P. Sabe o que eu queria perguntar para você? O que você acha que é violência? 
Carla: Eu morro de medo disso ... de ladrão ... Nem tanto de roubar, mas uma violência, vamos supor assim, sei lá eu, deve ser horrível ... Ah, estupro, eu morro de medo ... morro de medo, tenho pavor ... Eu escuto assim no rádio, na televisão, mas eu morro de medo, a coisa que eu mais tenho medo é disso. Se numa boa, às vezes, já é ruim ... você imagina sendo violentada. Então, eu penso assim ...

P: E alguma coisa parecida com violência ... já aconteceu na sua vida?, Alguma coisa ruim ... como você está falando?

Carla: $O$ fato de o meu marido fazer tudo isso, entendeu. Me xingar, para mim isso é horrível, horrível ...Eu tenho vergonha dos vizinhos ... porque é chato, os vizinhos escutam, já escutaram muita coisa, então eu fico tensa, nervosa, quando ele está no bar, porque eu não sei como é que ele vai vir, como ele vai me tratar ... Que ai já começa com agressões com palavras, isso para mim é a morte ... esse tipo de coisas.

Carla chorou bastante na entrevista, contando a sua vida com muito sofrimento. Como ela própria diz, seu problema é não sentir-se tratada como um ser humano.

A história de vida de Carla já começa com violência física e transtornos ligados aos papéis diferenciados esperados para homens e mulheres. A mãe dela, com dois filhos e solteira, havia transgredido a norma da virgindade feminina até o casamento e por isto tem menos direitos e deveria suportar, segundo ela, "tudo" do homem que aceitou casar com ela nesta situação e ainda deu o seu nome aos filhos ilegítimos. Carla critica a mãe por ter aceito a norma social, mas reconhece a norma. Filha ilegítima, Carla ganhou o nome do padrasto, mas sentia-se inferiorizada por representar a falta moral de sua mãe. Ela responsabiliza principalmente a própria mãe, e nem tanto o padrasto, pelas agressões sofridas.

Quando adulta, Carla continua criticando seu marido por xingá-la sem motivos. Mas permanece nesta situação, buscando obter algum controle em alguns campos- o da sexualidade, o dos bens materiais -aceitando, porém, as regras que aponta como injustas, e colocando-se como vítima até quando luta por autonomia. 
Vejamos o prontuário de Carla no serviço:

19/11/93 35 anos usa anticoncepcional oral. Depressão há 1 ano, usou calmante por conta própria sem seguimento médico. Há 2 dias dor em baixo ventre; tendência a obstipação intestinal.

Diagnósticos + condutas:

Depressão e ansiedade - encaminhada para Saúde Mental.

Dor em Baixo Ventre - Papanicolaou +exames

Obesidade - Exames

30/11/93 Dinâmica Familiar Saúde Mental:

Vem encaminhada Saúde do Adulto. Refere depressão, diz que já esteve deprimida no ano passado, chorava por qualquer coisa " medo do dia e da noite ", escondia objetos cortantes com medo de fazer besteira. Usou calmante e parou por conta, melhorou com ajuda da vizinha que conversava e dava atenção a ela. Sente medo de morrer. Foi criada pela mãe e pelo padrasto, não conheceu o pai. Padrasto maltratava, batia sempre, a mãe dava razão a ele. Diz sentir falta de atenção por parte da mãe que dava mais atenção para os outros filhos.

Refere ser casada há 15 anos e o marido é nervoso, ciumento e às vezes, ignorante. Ele trabalha por conta, quando as coisas não vão bem chega em casa e "desconta" nela. Tem um filho de 14 anos e, às vezes, sente receio de fazer com ele o que sua mãe sempre fez com ela. Quando está mal, trata o filho agressivamente e se preocupa porque ele assiste às discussões que tem com o marido. Não sabe se a depressão também pode ser por causa de fórmulas que tomou durante algum tempo para perder peso. Quanto ao encaminhamento, achou bom. Resolveu vir apesar de a mãe e o marido ficarem dizendo "você está louca". Tem medo de usar remédios e ficar dependente.

\section{6/12/93 Caso Novo Saúde Mental}

Expectativa: Espera encontrar alguém que a ouça com muita paciência, pois tem uma longa história para contar até chegar ao problema atual.

Avaliação geral: Paciente chora enquanto relata suas dificuldades com o marido. Disposta a ser escutada, porém tem medo de receber conselhos ou pressões como a de sua irmã, que diz para ela se separar logo.

Diagnósticos: Reação depressiva breve ( Estados de depressão, não classificáveis como maníaco-depressivos, neuróticos ou psicóticos, 
geralmente transitórios, nos quais os sintomas depressivos relacionamse de perto no tempo e em conteúdo a algum evento estressante ${ }^{5}$ )

Prescrito medicação

23/12/93 Pronto Atendimento Continua com dor em baixo ventre, ansiedade e obesidade.

\section{Diagnósticos + condutas:}

Ansiedade- Saúde mental.

06/1/95 Pronto Atendimento Queixas múltiplas- sudorese, aumento de pressão, enxaqueca, hipertensa, não se interessa mais pela SM.

\section{Diagnósticos + condutas:}

Enxaqueca - medicada,

Prevenção de Câncer ginecológico - marcar Papanicolaou,

Tireoideopatia- marcar exames.

16/2/95 Pronto Atendimento: Exames normais

\section{Diagnósticos + condutas}

Tireoideopatia - afastada

Ansidade-não quer Saúde Mental Prescrito medicação: Pasalix 2 cp. ao dia.

$$
\text { 16/03/95 - Colhido Papa }
$$

27/4/95 Retorno de Papa Não gostou de ir para Saúde Mental (SM) porque recusa grupo (ela havia sido agendada grupo terapêutico)

\section{2/12/96 Dinâmica Familiar de Saúde Mental}

\section{Encaminhada do ambulatório de especialidades}

Medo, mal-estar, depressão, insegurança, sempre associa com interrupção do medicamento para emagrecer há 3 anos. Dor de cabeça, pressão alta, o que faz com que procure o Pronto-socorro. A última vez, há 40 dias, descartou HAS e prescreveu medicação. Refere melhora mas tem medo de ficar dependente. Perguntada sobre relacionamento familiar chora e relata briga com esposo, é ignorante e insulta-a freqüentemente. Fala que o filho não é dele. Acha-se dependente do marido e relaciona esse comportamento com a forma como foi criada; pais autoritários não a deixavam trabalhar, atualmente o esposo reforça essa relação de dependência (não a deixando trabalhar). Como expectativa tem medo de ficar louca e não ter o controle sobre si, talvez alguém para ouvi-la e " apontar o erro". Fala do medo que sente de "cometer alguma besteira", como matar o marido e o filho, "isto era antes, agora estou melhor". Fala da irmã, por quem tem muito carinho, mas está longe, o que a faz sofrer muito, fala da dificuldade de visitá-la,

5 Reproduzimos aqui as definições diagnósticas correspondentes aos códigos utilizados, pertencentes à Classificação Internacional das Doenças IX. 
pois o marido tem ciúmes da relação das duas. Agendado grupo diagnóstico e mantido prozac

17/12/96 - grupo diagnóstico da Saúde Mental

06/01/97 Caso Novo SM - Agressões verbais constantes e inclusive físicas.

Avaliação geral : Paciente com características depressivas e ansiosas. Teve infância com situações de rejeição que se repetem no casamento (com marido alcoólatra),

Diagn: Estados de ansiedade (Várias combinações de manifestações físicas e mentais de ansiedade que não podem ser atribuídas a um perigo real e que ocorrem em forma de ataque ou como um estado persistente. A ansiedade é geralmente difusa e pode chegar ao pânico. (...)

Prescrito medicação.

Participou de terapia de grupo até $26 / 6 / 97$, sempre relatando brigas e agressões com o marido.

30/1/97 SM Volta da casa da irmã no interior o marido havia picado, retalhado um blazer novo dela. Partiu para bater nela, se atracaram e o filho veio defendê-la, brigaram pai e filho, e o filho bateu no pai. Ela agora acha que não dá mais. Vai na quarta-feira ao advogado que a DDM lhe indicou para tratar da separação.

06/2/97 Volta a ter desentendimento com o marido. Ele está mais agressivo e bebe constantemente.

No fim (26/06/97), abandona a terapia.

29/4/97 Atendimento de Enfermagem: Parou anticoncepção oral há 3 meses, faz coito interrompido. Leucorréia - corrimento branco, catarro próximo da menstruação.

Colhido papa.

O uso de serviço que ela apresenta mostra uma busca de respostas que não parecem ser encontradas: diagnósticos não confirmados e repetidos encaminhamentos para o setor de saúde mental, com aderência precária. Carla refere queixas no serviço que são consideradas vagas, mas acabam investigadas e remetidas por fim à Saúde Mental. Ela usa também outros serviços diversos pela cidade, como prontos-socorros e ambulatórios de especialidades, e até demonstra uma certa preferência por estes em relação ao ambulatório de atenção primária, porque os percebe como mais dispostos a pedir mais e melhores exames e a se empenhar para encontrar um possível problema. Nestes outros serviços ela 
também foi algumas vezes encaminhada à Saúde Mental, freqüentando uma psicóloga também no ambulatório de especialidades. Em sua avaliação, estes atendimentos (Saúde Mental) ajudaram um pouco, alguns mais, outros menos. Prefere os médicos que pedem exames e realmente investigam tudo. O marido lhe acusa de ir muito ao médico, mas ela diz que sempre que achar que tem uma solução para o seu problema irá atrás.

\subsection{Rosana}

A entrevista com Rosana foi feita apenas pela metade, porque ela recusou-se a continuar. Ela foi procurada por três vezes para realizar o segundo encontro e sempre dava evasivas até que, por fim, se recusou.

Rosana e seu marido estão juntos há menos de cinco anos e moram com o pai dela, que é mecânico, em uma casinha em cima da oficina. Ela reclama porque o marido não ajuda a manter a casa, chega tarde e gasta tudo o que ganha no jogo. Em seu relato, Rosana conta um pouco de sua vida e muito de sua conturbada experiência com os serviços de saúde.

Rosana faz acompanhamento na Saúde Mental e é uma mulher com diversos problemas em termos de autonomia. Diz que sua mãe a criou muito "presa", na barra da saia dela, fazendo tudo para ela, e que agora não sabe viver sozinha. Mesmo assim, busca se virar para poder se proteger de uma gravidez indesejada, ainda que pareça bastante confusa para uma mulher de aproximadamente 26 anos na época do episódio relatado:

A primeira vez (que tive relação sexual, eu fiquei com medo, pedi socorro para a minha cunhada, a minha cunhada virou a cara para mim ... Pedi socorro para uma colega minha ... que eu trabalhava junto com ela na lanchonete ... e aí ela falou assim - olha, vou fazer assim ... vou te dar um comprimido, de 21, e você vai tomando ... vai tomando, tomando ... quando terminar o comprimido você espera, se vier para você. Aí eu fiquei esperando, esperando, para ver ... quando acabou o remédio. Aí eu esperei ... Aí quando foi no outro dia, aí veio ... eu falei - ah, graças a Deus que veio 
para mim ... -, aí eu pensei que fosse ele que tinha tirado a minha virgindade ... mas foi depois, que eu conheci um outro rapaz, casado, né, eu não sabia que era casado ... aí foi o casado que tirou a minha virgindade ...

Rosana cuida do pai, cozinha e serve almoço para ele. Além disso, cuidava do filho de poucos meses na ocasião da entrevista. Sente-se extremamente inadequada para assumir as tarefas da vida e tem uma fala confusa e permeada de um uso de serviços de saúde importante e também extremamente confuso. Foi a única entrevistada que não seguiu o roteiro, porque não conseguiu contar uma história de vida linear, como as outras. Ficou falando de suas dificuldades com os hospitais e com o controle da fertilidade. Ela é tratada como "diferente" na sua casa, acha que todos pensam que ela não dará conta de cuidar do filho. Ao mesmo tempo, este filho foi uma busca dela, já que o marido não queria. Ela acabou constrangendo-o a aceitar a possibilidade, com o auxílio dos familiares e, por fim, fez tratamento para engravidar. Como no caso de Carla, quando se trata de valores próprios de uma boa esposa (no caso, ter filhos), Rosana consegue fazer valer sua vontade.

Ela tem problemas com a sexualidade, porque tem medo que o marido tenha outras e por isto quer que ele a procure. Por outro lado, não concorda com algumas práticas sexuais do marido e aflige-se muitíssimo com determinadas imagens de filmes pornográficos que ele coloca, especialmente aqueles com cenas de lesbianismo. O medo que sente de pensamentos homossexuais que lhe assaltam é uma das coisas que a fazem sofrer mais. O casamento parecia a Rosana uma saída para sua situação depois que a mãe morreu, mas segundo ela mesma, "não deu certo",e hoje vive uma situação insidiosamente violenta:

Ele estava fazendo não sei o que em casa e eu com ele (filho) no colo ... aí eu falei para meu sobrinho de 12 anos que chamasse a minha irmã ... ainda bem que a minha sobrinha estava lá, aí a minha sobrinha pegou ...... me colocou na cama da minha irmã e eu fiquei lá ... quase desmaiada ... com tontura, com tudo ... aí perguntou se estava melhor, falei que não, que estava rodando tudo ... aí me levou lá para o hospital e o médico falou não sei o que ... que estourou não sei o que dentro do ouvido ... e que agora tenho que tomar esse remédio. E quando fico à noite sozinha, começa a fazer aquele barulho, como se fosse um barulho de caminhão ... e 
à noite não tenho sossego, não consigo dormir direito. E é muita coisa na minha cabeça e eu não sei o que faço ... e eu pensando assim ... talvez tendo um filho, se o marido fosse mais carinhoso ... até que seria bom, né ... mas ... mas não deu certo. Então, fico no meu desespero, e eu não sei mais o que fazer ...

\section{P: ele briga com você?}

R: não, brigar não briga, ele fica brincando, ele dá chute ... bate na bunda ... aquelas gracinhas ... e eu fico nervosa ...

\section{$P$ : mas chega a machucar ...}

R: eu ... se mexer comigo eu chego a machucar ... porque eu já machuquei ele ... um dia que era para ele passar o ano novo lá em casa e passou na irmã dele, diz ele que passou na casa da irmã dele ... e aí ele começou a me provocar, me provocar, fiquei nervosa ... peguei o abridor e cheguei a furar a barriga dele ... sabe ... E aí eu sentei no caminho, perto dele ... fiquei olhando para ele e fui me acalmando ... Fiquei com uma raiva que até hoje tenho raiva ... sabe ... e aí minha cunhada fala - ah, você é boba ... você deixa seu marido ficar mandando em você ... você não dá ordem nele ... - - aí eu falo - se eu dou ordem nele, nem sei o que eu sou capaz de fazer com ele ... então ... eu fico quieta ... -, eu fico calma ... sabe ... não gosto que ninguém mexa comigo ... E eu fico desesperada quando vem uma conta para pagar e eu não posso pagar ... e ele na calma dele, não quer nem saber da vida, faz o que quer ... não compra as coisas em casa. Quem está comprando leite para ele (o filho) é o meu pai ... quem está dando roupa é a minha irmã ... quem está dando fralda para ele é a minha irmã ... Eu fico até com medo da minha irmã querer tirar ele de mim ... só por ela estar cuidando dele...

\section{$P:$ mas não consegue ...}

R: é, não consegue ... mas se ela descobrir que eu ando fazendo tratamento mental ... ela tenta tirar ... Tem muita irmã que faz isso ... e eu vejo na televisão fazendo isso, que elas tiram ... Até o pai se puder tira também ... se ele provar ... Até meu marido fica falando que vai tirar ele de mim ... é, ele fala assim, né ... ele falou que um dia vai embora ... que vai pagar as contas e vai embora ... E eu quero ir embora, só que aí eu ouço as conversas dos outros ... - é, teu filho vai ser judiado, ele vai judiar de você ... -, então ... - se fosse você não ia não, deixava ele ir embora e você ficava ... -, aí eu penso, - bom, vou ficar só com as paredes ... -, porque ele diz que a cama é dele ...que a televisão é dele, que o aparelho de som é dele ... A televisão também é dele ... e a televisão é minha, mas foi ele que pagou os consertos, porque ele mesmo que quebrou e mandou consertar. Pagou 150 ... então ele fala - se você quer a televisão tem que me dar 150 ....

Rosana teme o fim do casamento, apesar de queixar-se bastante. O marido não cumpre as obrigações que lhe parece que deveria, e não leva a sua indignação a sério. Ao mesmo tempo, a cunhada acusa que é sua própria culpa, já que ela "não dá ordem nele". Rosana ameaça: se der ordem pode até partir para a violência, já 
que não é escutada. A experiência de Rosana com os serviços de saúde também repete esta falta total de controle e uma sensação de ser destratada e não poder defender-se. Vejamos o seu relato acerca de sua gestação e parto, que apesar de longo, transcrevemos quase completo, pela sua clareza e frieza em mostrar o destrato de que se sente vítima, em sua extrema vulnerabilidade:

E aí a gente .... eu queria o filho, ele não queria, né ... aí juntou a minha cunhada, meu irmão, conversando com ele para ver se ele aceitava eu engravidar. Aí tudo bem, ele não aceitou muito ... mas eu parei de tomar o remédio assim mesmo. Aí quando parei de tomar o remédio a minha menstruação não vinha. Aí eu falei - acho que estou grávida -, aí eu ia no posto, nesse posto aqui ... pergunte para a moça se ela podia fazer o teste para mim, -, aí ela fez, perguntei para ela - e aí?, deu positivo ou negativo? -, - deu negativo -, e eu preocupada, não sabia o que fazer, né aí não vinha, não vinha, não vinha ... aí depois minha barriga começou a inchar, inchar e doer ... começou a doer o útero. Aí quando começou a doer meu útero aí eu falei para a minha irmã que eu não agüentava mais de dor, aí eu fui para o Hospital. Aí este Hospital deu um encaminhamento, falou - você vai lá para o Hospital das Clínicas e faz o ... e conversa lá, faz uma ficha e vê o que eles podem fazer para você -. Aí começaram a fazer os testes, mandavam vir às 7 horas da manhã ... eu tinha que sair às 5 horas ... 5 e meia ... Eu saía quase todo mês assim ... ia lá, fazia o teste, tudo, tomava remédio, tomava remédio. Aí quando terminou um mês, aí foi quando fui levar meu pai receber aposentadoria dele, aí ele falou - você pega o dinheiro, se você precisar de um remédio para continuar tomando ... -, aí eu falei não, pai, não precisa não, eu sei que eu estou grávida -. Aí quando foi um dia, vim aqui no posto e a médica falou que era positivo. Aí comecei a engravidar. Mas aí aqui eu comecei a fazer o pré-natal no quarto mês ... para fazer ultra-som. Aí quando foi para ter ele aqui, ele estava sentado ... assim sentado ... aí fizeram cesariana $e$ fórceps ...

Depois que eu fiquei internada nesse hospital, a minha cabeça mexeu mais ainda. Eu fiquei desesperada, eu queria trocar de roupa, queria tomar banho ... e não podia porque não tinha roupa para vestir ... e os médicos não iam visitar a gente, só iam visitar quando era hora de visita.

Me trataram mal, porque oh ... eu levei o exame ... eu fiz exame de coração, porque eu fiquei preocupada ... que eu subi, desci escada, caí com ele ... caí quando estava esperando ele, na escada ... e aí eu fui parar no Hospital, quem me levou foi o guarda ... aí chegando lá ... ele falou - seu nené está tudo bem ... -, eu fiquei preocupada de ter batido a cabeça ... alguma coisa. Mas eu caí de bunda ... e me falaram - ah, não, tem que cair de barriga, porque de barriga não pega o nené -, eu falei - não sei se vai pegar ou não vai, né ...

Aí depois quando foi para ganhar ele, eu cheguei lá e fica assim ... como você está ... fica assim ... olhando para a cara da gente ... sabe ... e deixam o papel ali e 
ficam olhando ... elas não mexem no papel ... não faz isso ... A gente fica lá sentado ... com aquela dor danada ... e ninguém faz nada ... aí mandaram a minha irmã ficar lá fora, porque ela não podia entrar ... Aí o médico fez aquele toque, a bolsa já tinha estourado ... aí ele fez aquele toque ... aí ele falou - ainda não está na hora ... você veio com acompanhante? - vim com a minha irmã -, - então você fala para ela que você vai ficar aqui ... internada -. Aí eu cheguei ... ela falou - você tira toda a sua roupa ... -, quando chegar no quarto, né. Aí a minha irmã entrou, tirei a roupa, dei para ela e ela levou, só ficou meu chinelo ... que até meu chinelo também foi roubado ... sumiu meu chinelo quando ganhei nené ... Sumiu lá ... aí eu fiquei andando até descalça lá ... Minha irmã teve que trazer um sapato dela para mim.

Aí eu fiquei, esperei para nascer e nada ... esperei ... fiquei desesperada, falei - meu Deus do céu, o que eu faço? com essa dor que não passa? ... -. Aí depois veio outra enfermeira, pegou ... colocou mais daquele negócio, não sei o que é ... um soro, né ... foram três injeções e três soro, para a dor ficar mais forte ... e aí eu comecei ... começou aquela dor, aquela dor, comecei a chorar, aí a enfermeira falou assim - ah, minha filha, você não quis filho?, agora agüenta ... vocês não querem filho?, então tem que agüentar ... -, aí vinha uma lá ... chegava até a chorar, de tanta dor ... e ela falava - não, não está na hora de você ganhar o nené ... de pirraça você vai esperar mais ainda ... Aí ela falou assim - agora é a vez de Rosana -, aí me colocou lá no corredor, fiquei no corredor. Quando cheguei lá me colocaram em cima de uma mesa, aí começaram com aquela coisa vermelha lá, para "dedetizar", coisar lá

Ai começaram ... Aí me falavam assim - oh, mãe ... está um pouco aqui difícil, viu ... a senhora vai ter que fazer um pouquinho de força para o nenê sair ... porque o nenê não está conseguindo nascer. Aí eu tentava, fazia força ... fazia força e não tinha jeito ... Aí me deram uma injeção nas minhas costas e não pegava, fizeram três vezes e não conseguiam ... Aí depois conseguiu ... aí meu corpo começou a adormecer todinho ... aí eu fiquei ... Aí esperei ... esperei para ver se ele nascia e nada de nascer ... aí ele cortou ... não sei onde ... só sei que senti um corte embaixo ... aí começou a cortar aqui embaixo ... e não deu certo ... Aí pegou, costurou de novo ... Depois que costurou embaixo, costurou encima ... aí foi a cesariana, né ... foi cesariana ... cortou em cima e o nenê saiu ... aí foi depois que me colocaram no corredor ... aí eu chamei o enfermeiro, que estava sentindo dor nas costas ... e abaixou um pouquinho o negócio da cama, né ... aí passou a dor ... Aí quando ele ligou para lá, chamou a enfermeira que me levou me deu aquela penicilina ... Aí vinha outra e falava - é, vocês são doidas de dar esse remédio para essa menina. A menina já está com 38 de febre ... -, - ah ... mas nós não tem culpa, não ... porque ela não falou que tem alergia, não ... por isso que demos o remédio ... - aí diz que chamou a médica lá ... a médica não me examinou, só olhou para a minha cara e foi embora. E nem veio me ver de novo. Só falou para a enfermeira - ah!, vocês param de dar comprimido para ela ... -- aí parou de dar o comprimido, e aí eu fiquei esperando ... esperando se resolvia, e nada de resolver. Aí chegou no dia da alta lá ... aí me deram alta, quando cheguei na portaria ... eu estava com a roupa ... que a menina não tinha trazido para mim ... e eu com desespero, com vontade de ir embora ... doida para ir embora, eu falei - não, aqui eu não fico ... nem que eu tenha que fugir ... -. Já tinha duas moças 
lá, daquelas de fardas ... eu falei - eu fujo daqui, aqui não fico ... não fico mesmo -, aí a minha irmã me levou, estava com 38 de febre... Aí nem repararam que estava com febre ... fui embora.

A relação de Rosana com o serviço é de uma falta de possibilidade de comunicação absurda. Ela sente-se destratada e retrata os funcionários como pessoas que não têm o menor respeito por ela como ser humano, tratam-na como uma coisa e estão sempre tentando eximir-se de responsabilidades e culpá-la pelo que acontece. A expressão ouvida por ela, "você não quis filho? Então agüenta” é bastante comum e já foi encontrada em outros estudos em São Paulo (SOUZA, 1992). A fuga dela do hospital, com febre e sem seu chinelo, que fora roubado, retrata de modo bastante eloqüente até que ponto a ausência de interação comunicacional pode ser danosa para a eficácia da ação estratégica em saúde. Sem compreender exatamente o que se passa, mas submetida completamente à instituição da qual necessita, Rosana tem um consolo: sente grande alívio de ter um espaço de conversa onde pode ser ouvida, na saúde mental do CSE:

Quando eu quero conversar eu venho aqui no posto ... converso com a Dra. (Saúde Mental)... ela dá meia hora assim para a gente conversar ... aí a gente conversa e eu vou para casa ... e aí quando começa a minha cabeça a ficar meia assim ... com idéias esquisitas, eu fico desesperada e querendo vir aqui para conversar. $E$ como eu não pertenço aqui, ao Butantã ... não tenho direito ... então eu fico desesperada porque se um dia falar - ah, não vai dar mais para passar aqui ... -, aí eu não sei o que eu faço, porque para desabafar com uma pessoa eu não consigo. E se eu desabafo, eu falo demais ... sabe ... falo coisas que pode ser que as pessoas nem aceitam ... então fico assim ... no desespero.

A psicoterapia é valorizada por ela, apesar do risco que percebe de o tratamento mental ser usado contra ela pela irmã e o marido para retirar-lhe a guarda do filho. Vejamos o registro de seu uso do serviço:

\section{8/05/95 Grupo de Contracepção:}

$\mathrm{Na}$ verdade paciente é muito confusa. Estava usando contraceptivo oral há dois meses, sem informações sobre os métodos, cheia de dúvidas e mitos. Orientada quanto ao uso correto de anticoncepcional oral. Paciente com problema em outras esferas, 
ofereço saúde mental para discussão dos problemas do ser mulher e da vida. Ficou de pensar a respeito.

15/04/96 Vem a um Atendimento de Enfermagem espontaneamente pedir para passar com psicóloga, porque é uma pessoa muito só e precisa de alguém para conversar. Paciente mostrase confusa. Refere ter hemorróidas, incontinência urinária e dor em fossa ilíaca esquerda. Paciente diz ter irregularidades menstruais.

22/04/96 Dinâmica Familiar/Saúde Mental: Volta pela terceira vez à Saúde Mental. Briga com o marido e pensamentos homossexuais.

Diagn: Histeria (Transtornos mentais nos quais alguns motivos, que o paciente parece não perceber, produzem quer uma limitação do campo de consciência quer distúrbios da função motora ou sensorial os quais podem representar uma vantagem psicológica ou um valor simbolico. Esta neurose pode caracterizar-se por fenômenos conversivos ou dissociativos (...)

Entra em acompanhamento na Saúde mental.

08/07/96 - Saúde mental Rosana "atrapalhada" com a vida. Tem dificuldade em lidar com o marido. Acusa-o de não ter as coisas que gostaria de ter, casa bonita e roupas. Fica com raiva e agride, ele ameaça ir embora, e ela tem muito medo de ficar só. Continuo conversando acerca da vida e contos de fadas.

Segue em psicoterapia, relatando suas dificuldades. Os profissionais desconfiam de rebaixamento intelectual. Pedida avaliação psiquiátrica, entram com medicação antidepressiva.

No atendimento clínico, para o anticoncepcional oral, e entra em amenorréia, com diversas consultas e exames até o ginecologista: que suspeita de ovários policísticos.

\section{Diagnóstico e conduta:}

Esterilidade - encaminhada para tratamento

05\5197 Atendimento de Enfermagem de gestante

Desencontro na relação sexual, ela quer ficar por cima, ele não quer. Quando realizado o teste de giordano (percussão nas costas) ela pula de dor costas ,acima da cintura e diz que o marido dá nela quando ela não quer ter relação, mas ela reitera que ele não bate nela....Sem diagnóstico e conduta

Questões detectadas/orientações realizadas - Dieta com resíduos, Buscopan, negociar uma posição sexual que não doa e conversar mais com ele (embora pereça ser muito difícil). Empresto o papel de Ultra-som para mostrar a ele. Trará na próxima consulta.

\section{Caso Novo de gestante}

Sexualidade: companheiro quase não a procura mais. Acha que ele tem outra, tem chegado tarde em casa, etc. Questão a ser abordada no PN: dificuldades com o marido. 


\section{Grupo de parto}

Fala do seu desejo de engravidar mesmo contra a vontade do marido. Sente solidão e falta de afeto por parte da família e do marido. Chorosa ao falar da indiferença do esposo em relação ao toque ou carinho na barriga. Voltou a chorar quando o grupo colocou a questão do afeto.

Reclama que não tem atenção do marido.

Conduta: Repouso e ficar tranqüila com a questão da gravidez. 0718197 seguimento pré-natal conduta.

Diagnóstico: dificuldades no relacionamento conjugal sem 06/10/97 PN: Problemas emocionais Cd. Em seguimento na SM

\subsection{Marluce}

Marluce tem 39 anos e mora em sobrado próprio, na favela, bem equipado em termos de eletrodomésticos e "luxos", como antena parabólica, que são alvo de inveja dos vizinhos, segundo ela. Ela é diarista, trabalhando em serviço doméstico alguns dias na semana. É casada há 20 anos e tem dois filhos, um com 26 e outro com 18 anos.

Nasceu na Bahia, mas foi criada em Minas, em um lugarzinho pequeno. Sua mãe era empregada doméstica e o pai trabalhava na lavoura ou carregava lenha. Seus pais tiveram 14 filhos e conseguiram criar seis. A violência física é cotidiana para ela desde a infância, assim como a necessidade de ação para defender-se:

Meu pai era muito severo, meu pai me batia de sair sangue ...

Enquanto ele não via o sangue assim, ele não soltava. Aí um dia me irritei, sabe o que eu fiz? Eu fui embora de casa, com 7 anos, fui embora, sabe embora?, sem saber para onde ... para uma fazenda. Aí eu fiquei com uma mulher lá na fazenda. Aí, depois, essa mulher me bateu e fui embora para outro lugar.

Vivia fugindo, eu era rebelde.

Esta rebeldia é para Marluce motivo de orgulho, mas também lhe parece que, por não se submeter facilmente à norma social, provocou todas as dificuldades pelas quais passou. Com 12 anos, Marluce trabalhava em uma casa 
como empregada doméstica em troca de moradia e comida, e estava, enfim, em um lugar onde era bem tratada e não apanhava, segundo o seu relato. Cuidava da casa e dos filhos pequenos do patrão, quando conheceu seu primeiro namorado.

Depois, com 12 anos, eu conheci um cara, que não é o meu marido. Aí já aprontei, fiquei grávida, aí que meus pais não queriam de jeito nenhum ...

Com 13 anos tive o meu primeiro filho. Esse cara eu sofria, aí foi um sofrimento ...

Ele me levou, aí eu desconfiei, porque dentro do quarto, sentada numa cama, é lógico, não era casa de tia nem coisa nenhuma, também não era tão burrinha. Aí em vez de eu gritar, fiquei quieta.

Eu estava entendendo que ele ia aprontar comigo, mas também ele não tampou a minha boca. Ele falou - você não pode gritar porque se você gritar a gente vai preso. E eu não sabia o que era ir preso, eu tinha medo. A gente não tinha muita instrução, mas a gente entendia alguma coisa.

Na hora que eu fiquei calada, por que eu não falei - não!, não quero ficar aqui não!, aqui não é casa da sua tia! -, aquele escândalo, dava um escândalo, né, foi o que eu devia, e esse escândalo eu não fiz. Então, eu não fiz escândalo, eu aceitei. Ele não tem culpa, porque se eu tivesse gritado, feito alguma coisa, ele não teria ficado comigo no quarto, né, mas eu fiquei caladinha lá ... porque ele falava - ah, se você falar é pior -, então eu não sei se eu tinha medo, sei lá ... Gostando não estava muito, não, mas não sei ...

Sem saber explicar porque não gritou, Marluce culpa-se por isto. Como não se defendeu, ela sente-se responsável exclusiva pelo que aconteceu. Para ela, ele não tem culpa, pois está em seu "direito" de seduzi-la, ela é que não poderia ter cedido. O fato de ter 12 anos na época, que legalmente caracteriza estupro presumido, não parece ter importância para Marluce. Realmente, o rapaz poderia ser preso por lei, mas jamais ela, menor de idade e, pela lei, "vítima" de violência sexual. Mas para a própria Marluce e para seu círculo social ela não foi vítima, mas responsável, por ter cedido ao desejo ou ao medo e ter transgredido a norma de virgindade até o casamento para as mulheres. Assumindo a culpa, Marluce introjeta a norma social e percebe a transgressão como exclusiva responsabilidade sua. No mesmo movimento, percebe-se como sujeito responsável pela situação em que se envolveu. 
Marluce engravidou deste namorado. O pai da criança, que tinha 27 anos, disse-lhe que iria para São Paulo e a levaria junto, mas logo desapareceu. Quando o pai dela, que morava na mesma cidade, descobriu a gravidez, foi até a casa onde ela trabalhava e morava, xingando-a de puta e querendo matá-la, mas as pessoas da cidade que estavam por perto não deixaram que isto acontecesse. Sem apoio dos pais ou patrões, Marluce decidiu-se por dar o filho, mas na última hora arrependeu-se. Com 13 anos, arrumou um emprego em São Paulo, deixou o filho pequeno com seus os pais (o pai aceitou porque era um menino, porque se fosse menina já havia avisado que não ficaria com a criança), e veio trabalhar na cidade grande para mandar dinheiro para ajudar seus pais a criarem o seu filho.

Já em São Paulo, Marluce consegue um bom emprego como doméstica, sente-se bem tratada, volta a estudar e está contente. Manda todos os meses dinheiro para casa, para o filho.

Então aí eu conheci esse homem. Aí a gente namorou, ela (a patroa) gostava muito dele, mas quando ele bebia aprontava, era outra situação que eu passava, era outro sufoco, mesmo de namorado. Ele bebia e aprontava, queria me bater ... podia ser no começo do namoro, já queria me bater. Ele bebia muito.

Aí ele falou um dia assim - ah, vamos casar? -, eu achava que ele estava brincando, falei - casar?

Marluce ficou preocupadíssima, porque ele não sabia que ela não era mais virgem e que já tinha um filho. Queria contar a ele e não tinha coragem, porque achava que ele desistiria do casamento. Qual não foi a sua surpresa e satisfação quando ele descobriu a verdade e falou que ainda assim casaria com ela. Marluce casou-se e mandou a certidão de casamento para o pai, que a levou até o cartório para conferir sua autenticidade e, a partir daí, voltou a recebê-la em sua casa. Ela havia reparado o seu erro. Mas o custo foi alto.

Aí a gente casou. Eu comi o pão que o diabo amassou. No primeiro dia, quando chegou em casa, bebeu, bebeu, encheu a cara e aprontou ... E bebia, bebia tudo que tinha direito ...

Panela minha até hoje eu guardo, de raiva ... que ele chegava em casa e quebrava, ele quebrava a televisão, ele pegava a televisão assim e jogava ... o bicho 
que dava naquele homem. (Minha patroa) via que eu estava machucada, porque (ele) jogava as coisas assim em mim ... Uma vez ele quebrou a minha mão, vê o que eu já passei, ele quebrou a minha mão. Outra vez isso aqui ficou tudo preto ... aí ela me deu um óculos, quando melhorou um pouquinho eu usava um óculos grande assim, para tampar. Ele quebrava as coisas em casa. Ele arrancava a minha roupa ...Rasgava a roupa que eu estava vestindo, se ele estivesse com raiva, ele rasgava. Ele quebrava as coisas, ele colocava fogo ... queria colocar fogo em mim. Ah, tentava colocar fogo. Um dia ele pegou televisão ligada e tacou no chão assim, a tempo de matar. A televisão foi explodindo assim ... pegando fogo, e eu corria. Ele chegava em casa e eu falava assim - você quer jantar agora? -, porque eu tinha que perguntar. Aí ele falava - não posso nem chegar em casa, já pergunta -, aí ele pegava a comida e pá!, no chão.

Se ele chegasse e eu não falasse nada, ele falava - e o que tem no bico? Não vai perguntar nada não? Não vai pôr a janta, não?... Quer dizer, eu não entendia.

Marluce, entretanto, reagia, em sua rebeldia. Conta para nós com um certo orgulho o que também está registrado em prontuário: também atacava o marido fisicamente, chegando a machucá-lo seriamente:

Que nem esse aí, no começo, só que era assim ... ele me dava uma, eu dava duas nele também ... não pensa você que eu apanhei sozinha não, porque eu tenho provas até hoje, ele já perdeu a visão, já perdeu a memória, porque eu bati nele, dei uma pancada na cabeça dele e deu aquele negócio nele ... deu ... coágulo ... ele perdeu a visão, perdeu a memória ... Eu cheguei no médico e falei ... o médico falou - mas ele ... só pode ter sido uma pancada, o que provoca isso, essa coisa que ele está -, aí eu falei - doutor, ele me batendo no meio da rua, na cara, e eu pá!, na cabeça dele também, deve ser isso - falei para ele.

O médico deu risada

O marido é provedor, e apesar das brigas constantes e das agressões físicas,

Marluce acha que ele ainda é um bom marido, já que para ela " todos os homens tem defeitos":

Nunca na vida queria outro marido, nunca, por nada. Porque todos os homens têm defeito, com todos os defeitos do mundo ele é o melhor. Dos homens que eu conheço, assim, das minhas amigas, que eu vejo, ele é o melhor. Porque duas coisas que ele não faz que eu odeio, que eu não gosto, homem que desrespeita a mulher, que passa uma e fala - oh, que mulher gostosa -, que mexe assim, na cara da mulher. Isso ele nunca fez, porque se fizer eu quebro ele, no pau. Outra coisa, ficar no bar e ficar bebendo. Antigamente eu agüentava, mas assim, do tempo que eu comecei a falar, saber que eu vivo sem homem, que eu não dependo de homem para viver, eu não aceito isso de jeito nenhum. Eu posso aceitar tudo dele, até me bater, agora ... Porque antigamente eu aceitei, mas agora certas coisas não aceito nada, de jeito nenhum, imagina. Não aceito, Deus me livre. 
Marluce sempre trabalhou, mas seu dinheiro era para sustentar os pais e o filho mais velho e nunca para manter a casa. Esta dependência material de um homem é bem mais grave quando se tem filhos pequenos, e é apontada por ela como uma das razões da perpetuação da violência:

Não, porque assim, quando a gente tem dois filhos pequenos, que paga aluguel, você fala - puxa, para onde eu vou? -, porque geralmente quem aluga a casa é o homem. Quando você vai alugar uma casa eles perguntam, o que faz, o que não faz, quantos filhos tem, essas coisas todas. Então, ele sempre fez isso, ele pagou aluguel, água e luz, sempre deu comida para meus filhos, nunca faltou nada, essas coisas. Então, eu achava que dependia dele. Eu trabalhava só que eu achava assim que o dinheiro que eu ganhava não dava para sustentar dois filhos, pagar aluguel, água e luz e ainda sobrar par comida. Eu ia passar fome, eu ia morrer. Que tem muita mulher que vive assim e não morre. Aí comecei a descobrir - puxa, tem tanta mulher que não tem marido, ou tem tanta mulher que tem marido e vive nessa vida ... Porque eu trabalho, tenho o meu dinheiro, não tenho filho pequeno, tem aquela casinha lá, e também se não tiver eu posso alugar um barraquinho ou outro ... então por que tenho que agüenta desaforo? Eu não vou agüentar, não ... não agüento. Agora, se ele quiser viver comigo é como eu quero. Eu falo para ele, pelo menos me respeitar. Eu respeito ele, por que ele não pode me respeitar? Pelo menos essas coisas (ter outras mulheres).

Durante toda a entrevista, Marluce busca argumentos que explicam a sua permanência no casamento. Sua experiência de vida não lhe autoriza a imaginar que poderia ter um destino muito diferente, mas com o tempo vai descobrindo que é possível "viver sem homem" e, assim, passa a ter necessidade de explicar porque permanece nesta relação, se poderia eventualmente ter outra opção:

É o que o pessoal fala - errar é humano, mas depois não é safadeza? -, então por isso que no começo que eu casei, eu tive que ficar com ele, porque eles achavam assim ... o pessoal falava - casou, tem que viver - meu pai amarrava nós, meu pai amarrava nós e aí batia em nós ... e a minha mãe estava com ele, falava mãe, vamos embora ... vamos fugir - ela falava - não, minha filha, a gente quando casa tem que viver com o marido -. E mesmo depois que eu fugi de casa, que ela me contava que ele batia nela, eu falava - vai embora, mãe, vai embora -, ela falava não, minha filha, a gente casa e não pode largar do marido - então tinha aquilo, tinha que casar e viver, apanhando ou não, ou passando fome ... Meu pai falava assim para a minha mãe, eu era pequena mas eu lembro - eu vou levar a compra para a outra -, aí ele fazia uma compra para a minha mãe e fazia uma compra para a outra, e ia para a casa da outra. E minha mãe agüentava tudo aquilo, ela sabia que meu pai ia para a casa da outra e ela agüentava. Agora, tem coisas que eu não agüento, não, não agüento mesmo. Tipo assim, ele falar - ah, vou encontrar com a outra -, ou - vou levar coisas para a outra, você fica aí ... -, imagina!, eu não agüentava mesmo ... Do 
jeito que eu não presto, eu fugi de casa e não vou fugir dele?

(...)

Olha a minha família inteira, as minhas irmãs todas sofreram. As minhas irmãs nenhuma tem marido que preste, nenhuma. Um pior do que o outro. Imagina, as minhas irmãs falam assim -Marluce, seu marido é um anjo perto do meu -.

Brigavam, batiam. Arrumava uma outra, iam no forró, chegavam no outro dia, coisa que o meu nunca fez isso. De todas as casadas, a que sofreu menos fui eu, e eu passei tudo isso, então imagina as outras.

Se a princípio pensava não ter outra opção, com esta experiência de vida, Marluce hoje entende que prefere ficar casada com o atual marido, que ao menos é provedor e não tem outras mulheres, apesar das brigas. Ela faz questão de definir este limite do insuportável para ela, até para defender a sua opção de vida, ressaltando as qualidades do marido:

Mas também nunca assim ... quando passa uma coisa, que precisa, meu marido compra. Que nem agora ele passou remédio, ele comprou. Ele pode estar brigado, mas ele vai lá e compra. É que nem aquele dia que a gente estava quebrando o maior pau, mas - já recebi, pode ir lá e comprar o remédio -, aí ele vai lá e compra.

Apesar de ser um bom marido, na sua visão, ele tem outro defeito: não a procura sexualmente com a freqüência que ela gostaria. Assumindo-se mais uma vez como rebelde, Marluce quer ter prazer, e esta exigência é uma das raízes das brigas do casal. Ao atacar o que considera uma falta excessiva de interesse sexual no marido, ela afronta a sua masculinidade e incita a violência, acabando por romper a possibilidade de comunicação:

Se eu não procurar ele não me procura. Aí eu vou deixando. Nossas brigas começam por causa disso, às vezes. Porque eu sei que outra ... quando a gente sabe que tem outra ... amigo dele, falam que ele é muito quieto. (Ter outra) então não tem, por isso que eu acho assim. Sair de casa ele não sai. Quando ele sai é para ir no mercado, sai de tênis, arrumado, às vezes sai com o dinheiro e volta, eu sei o que comprou e gastou aquilo.

É, aí, eu fico assim - puxa, se ele não me procura e não tem outra, é porque tem problema, então não vou procurar. Aí eu falo - vai no médico ... -, ele fala - não vou no médico, eu não sou doente -. E ele não vai no médico.

Eu falo - por que você não vai no médico, fala que você não gosta -, então, dessa vez ele quase me senta a mão na boca, quase que pega. Eu falei - você não gosta de mulher, meu?, por que você não procura?, estou cheia de ver homem que não gosta de mulher -, quando eu falei assim, ele estava sentado e lascou a mão 
assim na minha cara, só que não pegou. Aí mudei de conversa, porque estava provocando aquele dia. Eu estava provocando porque ele não me procurava, aí para ver se falava, só jogando indireta, jogando piadinha, só quando fica implicando? credo, tem homem que parece que está morrendo -, eu ficava assim - tem cara que é folgado -, - tem amiga minha que é casada, o cara procura todo dia, tem outros que é brocha -. Comecei com esse tipo de coisa, que não devia, queria apanhar mesmo. Para ver se provocava, se ele me chamava para alguma coisa. Pegou assim, - vou dar um tapa na sua boca -. Aí eu vi que não tem jeito, tem que ir no bem bom mesmo.

Ah, o cara nem liga, eu desisto, eu fico nervosa e já pego e já deixo para lá.

Aí quando ele briga comigo, ele me xinga, aí eu começo a falar, aí que começa a briga. Ele ofende que nem aquele dia, ele ofende assim - ah, você não estava no médico -, eu já penso que ele está falando que eu fui atrás de macho, aí para ofender ele, eu já pego e já falo - não, eu não estava no médico, eu estava atrás de macho ... -, e não é nada daquilo, mas a gente quer ofender porque não quer levar a pior. Acha que falando essas coisas que vai melhorar. E é onde começa, porque a gente briga, acho que qualquer casal briga. Então aí que começa, aí briga, fala isso, aí a coisa fica pior, em vez de melhorar. Essas cunhadas que eu tive todas largaram do marido, a mesma coisa, por causa disso. Viveram um ano, a que viveu mais foi um ano, e que falam assim.

\section{(...)}

Ah, eu acho horrivel, mesmo que ele não me procurasse, mas que ele fosse mais carinhoso, que essas coisas ele não é. Fica aquele cara, sem sal e sem açúcar, que não se preocupa. Mas não, ele fica em casa, não sai daqui da televisão. Ele arruma as coisas, não deixa louça suja, ele acaba de comer e vai arrumar a cozinha. Ele não se preocupa, eu falo - deixa a merda da cozinha para lá, rapaz, que cozinha ... -. O negócio não é cozinhar, é comer ... eu não falo isso ...

Aí eu falo assim ... - ah, meu Deus ... -, aí eu vou lá, me arrumo, passo perfume, tudo. E não adiantou, não é porque eu sou gorda, porque quando era magra era a mesma coisa. Já fui tão magrinha, com 49 quilos, e era a mesma coisa.

Marluce, ao contrário de Carla e Rosana, considera imediatamente que tudo o que aconteceu em sua vida pode ser chamado de violência:

Eu acho que sofri violência. Não é violência tudo isso? Sofrer de pai, depois casa e apanha do marido. No começo escondia de todo mundo, escondia e falava que eu caí, que machuquei, mas acho que todo mundo percebia. Porque eu não contava, porque ele bebia.

A importância da virgindade feminina e a importância do casamento fica claro também na história de Marluce. Seduzida pelo namorado, ela exercita sua sexualidade sem a mínima informação ou condição de controlar as conseqüências deste ato. Transgride e sente-se culpada pelo ocorrido, pois "não gritou", e arca 
sozinha com a gravidez decorrente. Este episódio a desvaloriza como mulher no código de seu grupo social muito mais do que desvaloriza a ele abandonar o próprio filho. Incapaz de criticar o próprio código moral, Marluce assume sozinha a responsabilidade por violar a norma de conduta sexual para as mulheres, buscando se colocar como sujeito de sua história. Ela não foi enganada, ela errou porque permitiu a relação sexual. Quando encontra um namorado que quer casar com ela mesmo com este passado, Marluce fica muito feliz, casa e volta a freqüentar a casa dos pais. Começa, então, uma vida de violências mútuas que é "livremente" escolhida e mantida por ambos. Se Carla e Rosana não vêem saídas, Marluce vê, mas a saída para ela pode ser ainda pior que a vida que leva. Ela assume sua situação como opção de sujeito, ainda que o sentido desta liberdade, nas condições que ela relata, seja bastante discutível.

Vejamos agora como o serviço de saúde retrata nossa personagem nos registros em prontuário:

\footnotetext{
\begin{tabular}{|l|}
\hline 15/03/94 Pronto Atendimento (PA) \\
Diagnósticos e condutas: \\
Infecção do trato urinário (ITU) - Exames, \\
Obesidade-dieta \\
19/04/94 retorno de PA \\
ITU- Tratada \\
9/12/94 PA \\
Varizes-meia elástica e marcar Papanicolaou \\
14/03/95 - Colhido Papanicolaou \\
11/04/95 Resultado de Papanicolaou \\
1919/95 Dinâmica familiar Saúde Mental \\
Vem à Saúde Mental encaminhada do hospital. Refere vários \\
problemas de saúde, como dor nas costas, mão dormente, sem \\
confirmação clínica. Acha estranho que coisas da cabeça possam \\
causar estes sintomas. Refere ser muito nervosa. \\
Briga com o marido todos os dias, porque não gosta de morar na \\
favela. Briga quando sai , quando chega, se falta água ... fala que já \\
bateu no marido porque "ele bebia muito ". diz que teve que fazer uma \\
cirurgia porque formou um coágulo no cérebro após ela ter batido nele.
\end{tabular}
} 
Diz que só bateu porque ele quis agredi-la, depois disto brigaram outras vezes se agredindo. Agora ele só bebe de vez em quando.... conta que o filho se dava bem com o padrasto mas um dia os dois brigaram e ele deu nove facadas no padrasto. Ele não deu queixa e depois ficou tudo bem. Agora o filho está bonzinho, virou crente, casou.

17/11/95 Caso Novo Saúde Mental - Queixa: Dores no corpo "os médicos não sabem o que a gente tem". Não gosta do seu corpo e sente-se gorda. Gostaria de medicação para emagrecer.

História da morbidade atual: Está tudo bem, só não gosta de seu corpo. Está gorda, come muito, pois é nervosa. É nervosa porque briga muito com o marido. Ama o marido, mas este quando bebe se torna violento, e ela entende que uma mulher não deve apanhar e revidar. Após as brigas tem insônia e fica nervosa.

24/11/95 Saúde Mental - Vem se indagando porque acha que não adianta, defesas maníacas reforçadas. Opto por conversar acerca de seu modo de ser, exponho objetivos do trabalho psicoterápico. Refere enjoar das coisas facilmente e, apesar das dificuldades (marido alcoólatra, morar em favela), com seu trabalho consegue comprar coisas melhores e viver melhor que os vizinhos. Opto por colocar em alta. Voltará caso perceba necessidade. $\mathrm{Na}$ saída chora, dizendo que o nervoso Ihe incomoda. Reforço minha disponibilidade, caso resolva retomar $\mathrm{o}$ atendimento.

19/04/96 - PA Varizes

16/01/97 - PA Hipertensão Arterial Sistêmica (HAS)

23/01/97 - PA: HAS + obesidade

6/02/97—PA: labilidade de Pressão Arterial

15/01/98 - PA: Neuropatia? HAS? Obesidade

03/02/98 - PA: HAS + obesidade. Motivo para o atendimento: Muito ansiosa, querendo exames. Achando que talvez não façam os exames necessários (que ela julga necessários).

12/03/98 PA: Personalidade histriônica + vertigens, labirintopatia Conduta: medicação sintomática

Marluce sente-se bastante doente, e em seu relato reclama bastante dos profissionais de saúde e especialmente dos serviços públicos e seu descaso com os usuários. Não parece estar tendo suas demandas atendidas, ao mesmo tempo em que procura incessantemente os serviços de saúde, não apenas o CSE como também vários outros. Estranho paradoxo de uma rebelde... O serviço, por seu lado, trata de realizar para ela ações sanitárias, preventivas de riscos e para detecção precoce de doenças. Colhe o Papanicolaou e diagnostica e trata a 
hipertensão arterial, mas não pode compreender nem explicar o sofrimento crônico de Marluce. Rebelde, ela reclama e insiste:

Estou com as mesmas coisas, a dor continua do mesmo jeito ... mas faz pouco tempo, foi aquele dia que eu vim aqui ...ele falou que é remédio da pressão, eu quero saber por que fico inchada, porque doem as pernas ... eu não sinto assim as mãos às vezes, fica com cãibra, essas dores, esses caroços que eu tenho. Eu deito e aí ele dói, para mim virar para o outro lado eu tenho que apertar, segurar, para voltar para o outro lado. Então, isso aí não tem a ver com a pressão, ele fala .

Então por que não mandou fazer os exames? Aí eu não gostei, hoje vou falar para a moça para passar num ginecologista.

Não tem remédio, mas pode eventualmente ter alívio. Marluce está condenada a reiterar a sua queixa ao serviço na esperança de encontrar alguém que a ouça. Ao mesmo tempo, deve ser esperta o bastante para utilizar bem os serviços e buscar conseguir deles aquilo de que precisa.

\subsection{Claudia}

Cláudia tem 59 anos e 37 de casamento. Já passou por diversas alternativas terapêuticas e é bastante reflexiva em relação à violência conjugal e sua situação particular. Mora em casa própria, em bairro de classe média, e o marido construiu e administra diversos imóveis para aluguel. Eles têm telefone, carro e casa na praia. Como mulher bem mais velha e experiente, conta uma história de relacionamento conjugal cheia de reflexões sobre gênero e violência. Foi a primeira entrevista e nos abriu perspectivas de análise.

Claudia nasceu no interior de Santa Catarina, em zona rural bastante pobre. Ela veio para Curitiba e depois para São Paulo, trabalhando como doméstica. Quando conheceu o marido, era operária e estava comprando um terreno. Ela tem uma curiosa interpretação do que significava o casamento para as mulheres em sua época:

O marido é um patrão, é um emprego. Era um emprego pra todas as mulheres, a maioria daquele tempo. Era um emprego. Eu nunca mais contribuí com a previdência, mais nada. Eu não sou aposentada. (Cláudia) 
Cláudia argumenta que uma mulher pode ter mais ou menos sorte com o patrão que lhe cabe, mas que na época em que casou havia duas possibilidades para as mulheres: ser prostituta ou casar-se. Ela escolheu casar-se, e teve de aprender a lidar com um difícil patrão. A associação que Cláudia faz, com sua forma pragmática e crítica de ver as coisas, não parece exagerada. Realmente, a "carreira" esperada para uma mulher nesta época e classe social era a do casamento. Daí vem seu sustento e também sua possível satisfação com o trabalho, já que abandonou seu emprego como operária ao casar-se. Sem aposentadoria, ela até hoje depende da negociação com o "patrão" para garantir sua possibilidade de algum dinheiro para gasto pessoal. Na sua longa história, Cláudia foi obtendo pequenos avanços: recuperou o título de eleitor, pois o marido a princípio a proibia de votar, tirou carta de motorista, conseguiu acesso a uma pequena quantia de dinheiro sobre a qual não precisava prestar contas. Claudia só voltou a votar aos 35 anos, quando tirou carta de motorista e teve de regularizar sua situação eleitoral.

Ouçamo-la contando suas dificuldades para "receber" aquilo que ela legalmente adquiriu com a cerimônia civil de casamento: a comunhão de bens.

Então, eu ficava..., eu nunca consegui assim, conta conjunta jamais, até hoje. Não confia. Então, é... aí eu falei: eu tenho que arrumar uma maneira de ter o meu dinheiro, seja pouco, mas eu sei que eu tenho pouco; é isso que eu vou gastar. Sem dar satisfação. Aí, ele foi trabalhar, tava aposentado já fazia três anos, um pouco parado, aí foi trabalhar. Então a gente recebe aluguéis dumas casinhas, aí eu passei a receber aluguel, recebia tudo. Punha no Banco, tal, conforme ele mandava, mas eu já tirava o aluguel de duas casas pra mim. Era pouquinho, sabe.

Ele sabia... E como ele tava trabalhando, ele tava com a cabeça tão descontraída, tão bem que ele não tava a fim de brigar por causa de dinheiro, porque ele tava ganhando também mais. E tava precisando de mim. Aí, um belo dia ele falou prá mim "Eu quero saber onde você põe o dinheiro, que você pega? No que você gasta? Você tem que anotar tudo prá mim". Eu falei "tá bom". Falei "tá, tá bom". Outro dia de novo, aí ele levantava de manhã, já gritando, por causa do dinheiro. Aí, quebrava o pau. Eu dizia "Ó, o dinheiro é meu, e eu não tenho porque anotar pra você, porque eu sei gastar o dinheiro. Porque quando você me conheceu, eu já tinha até um terreno meu". Não tinha nome sujo, tinha crediário, tenho até hoje, eu era eleitora, eu era tudo.

Aí, tá bom. Foi indo, foi indo, foi indo. Eu pegava dois aluguéis, aí ele me enchia de um tanto, perturbava de um tanto, era tanto na minha idéia, jogava coisa 
pra mim pagar, fazia compra e na hora não tinha o dinheiro, aí vinha pra eu dar do meu. Aí, eu comecei a ficar com um aluguel, deixei os outros tudo pra ele. Fiquei só com um. Aí, esse um ele queria satisfação, aí, falei "Não". "Você faz tudo que você quer, tudo, gasta o dinheiro onde você bem entende". Ele não põe fora assim, mas compra coisa que não tem a ver, mas não é escondido. E... eu sei o que eu faço do meu dinheiro, é problema meu. Então, dali pra cá, nunca mais ele aprontou por causa do dinheiro, mas é aquele pouquinho que eu pego.

Eu pago médico pra mim, consulta médica eu pago. Eu pago exame, às vezes..., gasto comigo. Remédio, pago a minha natação; sobrou, sobrou, não sobrou, acabou. É isso que eu quero. Então, é assim. E nesse meio aí, deu muita porrada, nossa.

Ele vivia de porrada por cima de mim, de murro, pra me amedrontar. Pra mim ceder como ele queria ser o meu dono. Porque se eu tinha dinheiro, a mulher que tem dinheiro, ela se defende; a que não tem nada, fica mais submissa. Então, disso daí, eu saí de baixo. Saí de baixo. (Claudia)

A vida de Claudia é uma luta por reciprocidade nas relações como ser humano, para "sair de baixo", como ela diz. O casamento que ela descreve é mais uma escravatura que um emprego, já que tudo o que construiu com o marido é, na prática, apenas dele, ainda que na lei ela tenha direito a uma parte do patrimônio do casal. E Claudia conhece a lei. Ao mesmo tempo, conhece melhor ainda o seu cotidiano e o de seus conhecidos, que diferem radicalmente da lei. Esta autonomia sobre um pouco do dinheiro e a sensação de um maior controle sobre o próprio destino foi conquistada por Claudia em um longo processo reflexivo, em que tiveram papel importante as diversas terapias que realizou e o recurso à homeopatia. Como Marluce, ela descobriu que "podia viver sem homem", e que estar nesta situação é opção dela. Como Marluce, sente-se responsável pelo que lhe acontece, sujeito de sua vida, e nunca sujeitada.

Como nossas outras entrevistadas, Cláudia também fala da dificuldade de separação e da pena que sente do marido:

Porque de tanta briga e eu não queria mais..., brigar e falar as coisas pra ele, brigaiada, briga, briga direto. Brigar a noite inteira! A noite inteira brigar, menina. Daí ele fica... fica por morto, fica caindo pelos cantos, desmoronado, aí eu fico com dó. Viu? Eu fico com dó. Estou contando prá vocês a verdade. Fico com dó. Então, agora já nem brigo, nem mexo muito com a coisa, sabe. Não adianta, porque eu não tenho pique pra... pra... tomar uma decisão... Eu não sou obrigada a ficar com ele. 
Claro, que eu não sou. De jeito nenhum. Mas eu não consigo, não tenho nenhuma iniciativa pra separar dele, não. Já tive, já... mas, quando estava com tudo engatilhado, advogada arrumado, tudo, eu adoecia... Eu ficava tão doente, tão desmoronada, que eu não ia conseguir. Não tinha nem voz mais (Claudia).

Sempre que pensava em separar-se, Cláudia sentia-se imobilizada. Conta que chegou a ficar três ou quatro dias no sofá. Considera a possibilidade de separação indicativa de um fracasso dela como mulher, e pondera que suas irmãs que se separaram estão pior hoje do que estavam casadas. Busca, em contrapartida, aumentar o seu poder no interior do casamento. Depois de muita terapia e homeopatia, às quais atribui o mérito de tê-la auxiliado, hoje tem uma postura diferente quanto à importância do homem e da mulher na família:

Por que que no lar o marido que trabalha fora, que traz o dinheiro, que..., como diz "dá aquela segurança pra família", se ele vive com uma mulher, lado a lado, por que que ele é mais importante que ela? Ele não é. A função dele é importante e a dela? Também é muito importante; sem a dela, ele não seria o que ele é..., não seria. Inclusive eu acho que quem... quem administra um lar, uma família é mais a mulher do que o homem. A mulher, se ela tem capacidade, se ela sabe, ela resolve muito mais a... a organização da casa, da família, do dinheiro, da distribuição de tudo, melhor que o marido. Como quem diz, no meu tempo, da minha mãe, falava "ah, o marido é o esteio da casa", mas não é, é a mulher; mulher é o esteio da casa. A mulher, ela consegue coordenar muito mais coisas do que o homem..., muito mais. Então, não é o homem que mantém uma... um lar de pé, não é; é uma mulher. Uma família bem sucedida, geralmente vem mais da mulher, mesmo que ela não trabalhe fora, que ela não traga o dinheiro mas, se ela souber administrar..., inclusive se ela souber é..., conviver com esse marido, saber é..., manter as regras e viver a dois.

Eu... olha, a mulher com um marido complicado..., prá viver com ele, ela tem que em primeiro lugar, tratar dela..., tratar dela, procurar se orientar da maneira que ela puder. E... primeiro ela saber, descobrir a falha dela, prá ela poder chegar na falha dele.

Não se muda ninguém, ninguém muda; a gente não muda ninguém, a gente muda a gente. Como eu já mudei, mudei bastante. Eu acho que estou boa, eu já estou boa, estou no ponto. (Claudia)

Assumindo-se como sujeito, buscando empoderar-se, Cláudia de certa maneira ambiciona inverter os papéis: o marido não é o mais importante na casa, mas sim a mulher. É a mulher que deve mudar, assumir o controle e assim chegar na "falha dele". Cláudia parece ter consciência do papel que teve a doença no seu caso, já que melhorou da saúde quando começou a mudar o desbalanço de poder 
na relação com o marido. Vejamos o que ela diz sobre esta relação e sobre as mudanças atuais nas relações entre homens e mulheres:

Olha, a mulher hoje, os casamentos já estão diferentes. Isso ai é coisa do meu tempo, é o que eu acho do meu marido..., O que muda o homem, não é ele que muda, é a mulher que muda. As moças, hoje, estudam. Uma coisa que eu acho muito errado, as moças se casam sem nunca ter feito uma terapia, não é... "Ah, Fulana é louca, fazer terapia...vai... Fulano é louco". Não é. O povo acha, mas muitas pessoas não são nem doentes, sofro, sofro, sofro, não é. Ele tem alguma coisa emocional, alguma coisa... psicológica com ele, e ele reage na doença. Foi o meu caso, por exemplo. Eu reagi em doença, é uma maneira de mostrar como é... "olha, como eu sou uma coitadinha, está vendo, estou doente". Isso já era desde o tempo da minha mãe, doentinha, do tempo da minha mãe. Então, as moças hoje... , porque todo homem manda, é só deixar, todo homem. Hoje, também, é só deixar. Então, hoje eles estão diferentes, vão mudar cada vez mais porque, a mulher está evoluindo..., está evoluindo.

Cláudia chama a atenção para o papel da doença na sua vida, como produtora da idéia de coitadinha. O prontuário de Cláudia tem apenas uma passagem pela saúde mental do serviço. Vejamos o que foi registrado:

23\4\90 Caso Novo Saúde Mental

Conta que pensava em suicídio "qualquer coisa que me contrariava". Tentei suicídio, queria uma morte que não sofresse. Tentei tomar veneno, mas não cheguei tomar. Agora teve muita briga e muita pancadaria na minha casa. Sempre tive muitos problemas com o marido que é um espancador, mulherengo, avarento e cismado. Quando punha na minha cabeça que ia me separar dele eu ficava tão mal, tão deprimida e pensava em suicídio. Eu esperava um milagre para me fazer feliz. Eu agora ando briguenta. Eu tava muito passiva, parada com dor no corpo; mas mudou meu remédio na homeopatia e me deixou mais positiva, mais enérgica. Eu não tenho fibra para eu me separar dele. Ele não quer me largar de mim por causa dos bens. Eu tenho muita depressão. Me dá muita raiva de tudo que eu deixei passar, eu fico revoltada de não ter agido,. o marido é avarento. Ele era meu dono. Eu deixei porque a minha sogra criou minha filha com medo. Ele batia muito na gente, ele a espancava (filha).

Fez algumas sessões na SM. e ganhou alta.

Profissional registra: pessoa controladora.

Seu uso de serviço foi predominantemente realizado em terapeutas particulares e homeopatia. É interessante notar que ela, que é a entrevistada que 
realmente logrou obter maior controle sobre sua vida, seja percebida, na saúde mental, como pessoa controladora...

Vejamos agora a ação do serviço, adentrando na análise do processo que transforma ou não mulheres em portadoras de problemas de saúde, que podem (ou não) ser resolvidos pela ação técnica.

Analisaremos esta ação de três "pontos de vista" principais: a observação das atividades individuais, a leitura dos prontuários e do banco de dados sobre consumo de serviço e os depoimentos de profissionais e usuárias sobre a conexão existente entre saúde, violência e uso de serviços. Estes três ângulos de visão são complementares e referem-se ao mesmo objeto: as ações em saúde, de perspectivas diversas, como já comentado aqui.

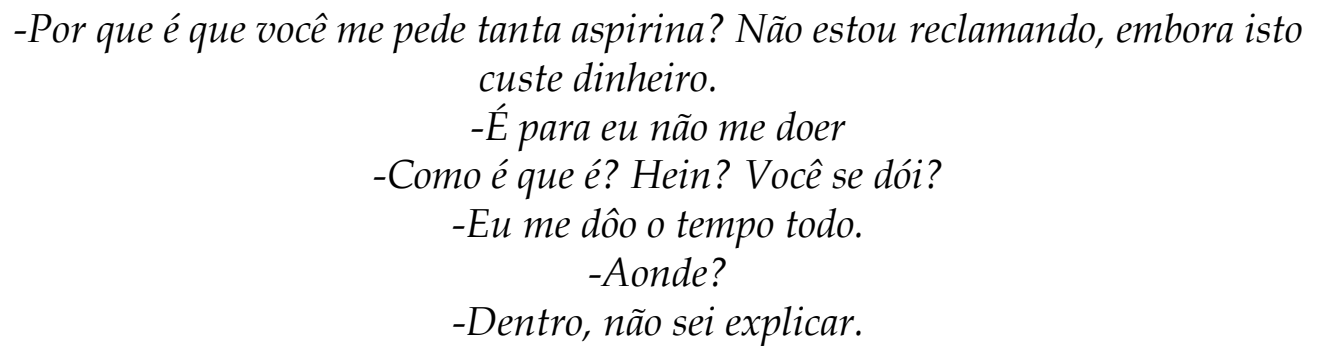

A Hora da Estrela, Clarice Lispector

\section{Condições de emergência, acolhimento e} resposta: A observação direta

Passamos agora à apresentação dos achados encontrados na observação direta das atividades. Como já descrito, foram observadas 142 mulheres usuárias em 57 atividades assistenciais e/ou educativas, grupais e individuais. 
Apresentaremos a princípio os resultados desta observação e depois o que foi encontrado nas entrevistas com médicos e usuárias e nos registros em prontuários que podem trazer mais elementos para nossa análise, para por fim realizar uma síntese.

\section{A observação direta}

As situações de grupo foram bastante bem favoráveis à emergência de questões relativas às relações gênero do que as consultas individuais, e também possibilitaram muito mais relatos de violência. Em sete dos 16 grupos observados foi percebido algum relato considerado como situação de violência, enquanto dentre as 41 consultas individuais apenas uma possibilitou a emergência de situação considerada como contexto de violência. Mesmo considerando-se que havia mais mulheres presentes nos grupos do que nas consultas individuais (101 nos grupos e 41 nas consultas), ao analisarmos as condições gerais de trabalho, os grupos demonstraram uma permeabilidade muito maior para o problema procurado, pela sua forma específica de atuação. Isto corresponde ao esperado, pois os grupos foram criados no serviço justamente para possibilitar esta abertura e a interação entre usuárias, e destas com as profissionais.

Isto contrasta com a leitura de prontuários, que mostrou um registro relativamente baixo nas atividades grupais, quando comparadas com a assistência pré-natal individual, ou com os atendimentos de saúde mental, como veremos. Parece-nos que, apesar de o grupo ser um espaço de emergência privilegiado, esta emergência não é imediatamente registrada em prontuário. Nenhum dos casos de violência institucional teve este tipo de registro, e apenas dois dos casos de violência sexual foram registrados. O grupo facilita, portanto, a emergência, algumas vezes acolhe e busca responder ao problema, mas não necessariamente realiza o posterior registro em prontuário. 
As atividades grupais operam predominantemente $o$ eixo educacional/comunicacional do PAISM. Esta classificação foi proposta por D’OLIVEIRA (1996) ao analisar o conteúdo e a proposta do Programa, que foi dividido, para este fim, em quatro eixos de saber e prática: clínico, epidemiológico/sanitário, educativo/comunicacional e psicológico. Estes eixos estão mais ou menos presentes, a depender da operação de cada atividade proposta para ser implementada pelo PAISM.

A nosso ver, a importância do eixo comunicacional como proposição para o trabalho obriga a coordenadora do grupo a abrir espaço para a fala das usuárias como uma exigência tecnológica, e facilita, assim, a emergência da situação de violência e relações de gênero conexas a questões de saúde reprodutiva abordadas nas atividades.

Nos grupos as condições de fala são mais propícias a esta emergência. Cada profissional lida com uma média de 7,5 usuárias, e seu trabalho é tentar garantir a possibilidade de fala para todas, facilitando a oportunidade para fazerem colocações, concordarem ou discordarem. Esta situação pareceu diluir o poder profissional e ampliar a interação, que deve ser estimulada pela profissional para o "sucesso" do grupo como trabalho. Surgem, assim, interações entre as usuárias, baseadas na importância das experiências comuns, facilitando o trabalho das profissionais. Isto fica claro quando as profissionais de enfermagem, principais coordenadoras dos grupos, avaliam mal aquelas atividades em que as usuárias colocam-se pouco, porque, nestes casos, cabe a elas conduzir quase um monólogo composto por um conjunto de informações biomédicas durante toda a sessão, sendo estes grupos percebidos como mais rápidos, mas também mais cansativos e desinteressantes para as usuárias e para as profissionais. Estes grupos, entretanto, não são muito freqüentes e não observamos nenhum com estas características em nossa pesquisa. 
Por outro lado, também pode acontecer de as usuárias interessarem-se e falarem muito, ampliando bastante o leque de questões e assuntos abordados e desviando-se muito do que é percebido como tema principal da atividade. As profissionais sabem, por treinamento e experiência, que devem controlar estas falas para que não se afastem do "fio da meada" condutor de seu trabalho, a passagem de informações educativas de cunho biomédico, ainda que devam propiciar a colocação de todas e a discussão destas informações no contexto prático das mulheres presentes.

Assim, equilibram-se usualmente na difícil tarefa de suscitar a discussão e a emergência da experiência das mulheres, sem perder o controle do rumo pretendido para o trabalho, que é discutir as diferentes posições e informar sobre um determinado tema reconhecido por todas as presentes como um problema de saúde. Em nossas observações, estes temas são as Doenças Sexualmente Transmissíveis, a AIDS, a contracepção, a prevenção de câncer ginecológico e a gravidez e o puerpério, tradicionais temas de saúde reprodutiva.

Já nas consultas individuais, no serviço estudado, operam-se predominantemente os eixos clínico e sanitário/epidemiológico. Controle de riscos, prevenção de doenças, diagnóstico precoce e terapêutica são os objetivos principais aqui. Estão presentes a estas atividades apenas dois sujeitos, no máximo três (em algumas consultas de pré-natal o marido estava presente), um dos quais é um profissional com autoridade técnica superior ao outro componente da relação. As consultas médicas e também as de enfermagem têm um roteiro próprio a ser cumprido, que consiste em inúmeras perguntas padronizadas, que buscam triar riscos ou detectar patologias, e o trabalho consiste em uma série de aconselhamentos à usuária (por exemplo, em termos de hábitos na gestação, como exercícios ou relação sexual, alimentação, evitar medicamentos, etc.), e a prescrição de exames e medicamentos. 
A interação proposta no mundo do sistema não facilita a emergência da violência diretamente como problema do mundo da vida, neste caso, mas constrange sua transformação em linguagem da doença. Enquanto nos grupos a "conversa" pode ser até certo ponto positiva para os objetivos da atividade, aqui os desvios do roteiro principal são um obstáculo à conclusão da consulta a contento, e a interação tende a ser quase exclusivamente estratégica. Mesmo com estas condições de diálogo, o atendimento individual, especialmente o pré-natal, permitiu a emergência e o registro de questões como as aqui procuradas, já que sua anamnese pesquisa ativamente a situação de relação conjugal, aceitação do filho pelo pai da criança, sexualidade e outros temas de "fronteira" entre o saber biomédico e as relações de gênero. Neste caso, abrem-se brechas para o surgimento de questões não estritamente biomédicas, brechas estas introduzidas na anamnese clássica pelo modelo tecnológico de trabalho adotado, em consonância com a idéia de integralidade que norteia o PAISM, conforme (D’OLIVEIRA; SENNA, 1996).

Nestas áreas de fronteira, o mundo da vida é ativamente escrutinado para geralmente ser disciplinado pelo saber biomédico. Mas, como bem sabemos, isto nunca acontece por completo, e a percepção das relações de poder existentes e a busca por práticas educativas mais simétricas também fazem parte desta interpretação do PAISM (D’OLIVEIRA; SENNA, 1996).

O último eixo identificado no Programa é o psicológico, que no serviço estudado concentra-se em atendimentos psiquiátricos e psicológicos grupais e individuais coordenados em um setor de Saúde Mental no CSE, referência interna para o PAISM. A primeira consulta deste setor, a Dinâmica Familiar da Saúde Mental (DFSM) e o Caso Novo de Saúde Mental (CNSM), mostraram-se espaços privilegiado de registro de situações de violência. A nosso ver isto ocorreu por ser a conversa conduzida como uma entrevista aberta, tecnicamente centrada na história de vida e dinâmica da vida familiar da usuária, e por haver ampla escuta e registro. 
A organização da assistência (tipo e modalidade de atividade), os eixos de trabalho priorizados (clínico, sanitário/epidemiológico, educativo/comunicacional ou psicológico), e a conseqüente forma de operação do trabalho foram condições importantes, a nosso ver, para a permeabilidade do serviço para o problema violência, assim como o comportamento de cada mulher quanto ao uso de serviços de saúde e o desempenho de cada profissional. Contribuem também para esta permeabilidade o tipo de profissional (médico ou auxiliar de enfermagem), e o sexo deste profissional, embora estas duas últimas características não tenham nos parecido tão importantes 6 .

As 142 usuárias observadas têm de 14 a 59 anos, distribuídas prioritariamente na faixa de 14 a 30 anos (65,5\%). Quanto ao estado conjugal, $76,1 \%$ moram com o companheiro, somando-se a categoria de casadas e união consensual. A grande maioria estudou até o primeiro grau incompleto $(72,2 \%)^{7}$. Elas têm também poucos filhos: apenas 16,9\% têm 3 filhos ou mais. A população atendida pelo serviço na época da pesquisa é bastante homogênea, e as mulheres representam parcela importante do total de adultos atendidos, perfazendo mais de $70 \%$ do total dos atendimento na saúde do adulto.

As auxiliares de enfermagem estão mais próximas, em termos de experiência de vida, das usuárias do que os profissionais médicos. Em uma das consultas de enfermagem observada, por exemplo, a paciente era uma mulher que estava fazendo o curso de auxiliar de enfermagem, o que gerou uma conversa sobre os horários e qualidade dos diversos cursos disponíveis que não tinha mais nenhum sentido tecnológico para o trabalho, transformando-se a consulta em uma

${ }^{6}$ Ainda que esta observação não tenha nenhuma pretensão representativa do ponto de vista estatístico, é interessante lembrar aqui que trabalho quantitativo recentemente realizado entrevistando médicos e médicas americanos sobre sua aderência a programas de screening para violência contra a mulher, não mostrou diferença entre médicos homens e mulheres (Rodriguez, 1999).

7 Dado do cadastro da população de mulheres atendidas no CSE, 15 a 50 anos, à época da pesquisa. 
conversa informal entre iguais, única vez em que isto aconteceu em nossa observação. Isto, provavelmente, porque o trabalho em saúde tem a hierarquia de saber e poder como uma de suas premissas: o saber profissional por princípio não é compartilhado, e a diferença de autoridade técnica (que, como vimos, transmutase em moral) é uma constante.

Note-se que o diálogo, apesar de ser travado principalmente entre mulheres, uma parte delas com características bastante semelhantes entre si, é realizado na situação de trabalho, na maioria das vezes, por mulheres que não são homogêneas e apresentam uma primeira e importante diferença: sua inserção na instituição de saúde onde se dá esse diálogo. Enquanto algumas são auxiliares de enfermagem ou médicas, vozes institucionais, outras são usuárias/cidadãs no serviço de saúde, vozes pacientes. Essa primeira diferença denota as distintas autoridades de cada um dos dois grupos aqui constituídos. As agentes institucionais estão investidas de um poder e uma autoridade que molda sua fala e suas conseqüências. Relação em princípio assimétrica quanto ao conhecimento, mas que não necessariamente assim deva ser quanto à competência ético-política sobre o que se fala e a interação no diálogo. Estas mulheres possuem situação soioeconômica próxima à das auxiliares de enfermagem e compartilham com elas,e em menor grau com as médicas, "praticas de gênero": comungam de alguma maneira a experiência de ser mulher na cidade de São Paulo. Em síntese, as profissionais podem ser vistas como um 'duplo', isto é, femininas por situação de gênero e 'masculinas' por condição tecnológica, reproduzindo na enfermagem o poder médico ${ }^{5}$. Mas este poder é

5 A idéia do "masculino" quer fazer referência, claro, à posição de poder da autoridade desta fala, uma vez investida cientificamente. Apesar de estarmos ora trabalhando na polaridade masculino-feminino como metáfora à soberania de um dos sujeitos na relação dominantesubordinado, nem estamos identificando todos os homens mecanicamente a poderes soberanos, nem pretendemos reduzir o feminino (e todas as mulheres) à inexorável condição de subordinação, bem ao gosto de certa vitimização da condição de mulher. A força retórica, neste caso, dá-se apenas como contraste dos termos. 
tensionado internamente pela própria proposta do PAISM (D'OLIVEIRA, 1996), que o coloca em questão para todos os profissionais em suas relações com as usuárias.

Apesar desta diferença inicial, é interessante ressaltar que se nota também uma interseção nos dois discursos: as usuárias têm sua fala permeada pela fala institucional, e as trabalhadoras também falam, às vezes, como "usuárias". As auxiliares de enfermagem são as profissionais que "confundem" mais os discursos, provavelmente por sua maior proximidade, tanto de classe social como de saber e cultura, com as mulheres usuárias.

Como veremos, nossa observação demonstra uma tensão constante entre as questões práticas da vida das usuárias (incluindo questões sobre sexualidade e violência), e a tradução destas questões em anormalidades do corpo, passíveis de intervenção - o discurso competente da medicalização, a linguagem da doença. Trata-se da tensão existente entre o mundo da vida, com suas questões práticas, e o mundo do sistema, com o seu saber técnico sobre o bem viver e suas propostas de intervenção.

Estaremos aqui lidando com um problema do mundo da vida que solicita sentido e reparação aos serviços de saúde, a violência contra a mulher. Traduzir estes acontecimentos para tomá-lo como parte do trabalho em saúde encerra complexas questões. Procuraremos mostrar que esta apreensão se dá na conexão entre interação intersubjetiva e intervenção racional dirigida a fins sobre um corpo anatomopatológico. Sem ser reduzidos a doenças, os acontecimentos relativos às relações interpessoais privadas não têm respostas no saber biomédico de base científica. Os livros texto não ensinam a resposta a dar em questões deste tipo, como bem apontou um de nossos médicos entrevistados ao comentar o trabalho com as queixas relativas à sexualidade:

A sexualidade não tem muito a ver com doença ginecológica. $O$ ginecologista entende, basicamente, de doenças ginecológicas. Eu acho que a formação da gente não é para ... não é muito adequada para abordar dificuldades na vida sexual, porque 
basicamente não são problemas ginecológicos (médico).

Por outro lado, como o mesmo profissional aponta em relação ao assunto da violência, este tipo de tema tem e não tem a ver com as doenças que são objeto indiscutível da prática, e tem e não tem a ver com o uso de serviços. Isto porque, apesar de não apresentarem respostas bem definidas para problemas da vida prática, os profissionais são impelidos a lidar com ele, seja por pressão dos pacientes, seja porque assim o recomenda o modelo tecnológico adotado, e só assim poderão seguir com o seu trabalho, realizando o cuidado em saúde. Para abordar estas questões, os profissionais têm de se valer de sua experiência prática, ou seja, da arte consubstancial à técnica.

Esta abordagem interativa, no entanto, ainda que ocorra, não garante a possibilidade de uma prática emancipatória. A autoridade técnica do profissional pode ser transmutada em autoridade moral e suas opiniões passam a ter mais valor, pois supostamente ancoradas em seu saber científico (Schraiber, 1993). Neste caso, a interação é estratégica, como é o caso da transmissão de informações ou valores contida na educação em saúde tradicional. Os profissionais não se furtam a dar várias recomendações sobre hábitos, relações pessoais e formas de atuar nas questões práticas da vida, operando seu saber tanto prático como de base científica e ditando toda uma norma para o bem viver. Recomendam o uso da camisinha, a alimentação adequada, o diálogo com o marido, a maternidade e paternidade responsável, a idade própria para a gravidez e orientam até mesmo sobre a depilação ou não dos pelos pubianos.

Mas quando, respondendo a este convite, as questões do mundo da vida emergem na fala das mulheres, buscando respostas do saber técnico, pudemos observar o esforço e a dificuldade dos profissionais, apesar de suas boas intenções, para lidar com esta emergência e procurar dar algum sentido tecnológico para ela, o que nem sempre é possível ou desejável. 
Ao não encontrar resposta para os problemas autenticamente enunciados, mas sim ruptura comunicacional, as mulheres recorrem a uma tradução que possa viabilizar a interação. Para isto, as usuárias falam a linguagem da doença, recortando daquilo que é da vida o que imaginam possa estar no corpo e almejando assim a reparação potencial prometida pelos serviços. Esta pode ser uma explicação para os "pacientes detestáveis, ou difíceis": o bloqueio à livre expressão de suas demandas os constrange a procurar restringir suas queixas ao que pareça somático e, portanto, passível de solução no plano dos serviços de saúde, buscando ocultar as dimensões sociais e psicológica dos problemas, embora nem sempre com sucesso.

Ao remeterem seus sofrimentos ao serviço, já transformados em potenciais patologias, os profissionais, especialmente os médicos, não poderão responder se não encontrarem alterações anatomopatológicas em seu corpo. Quando, ao contrário, o pedido é por orientações técnicas em problemas práticos da vida privada, os profissionais em geral tenderão a descartar a demanda por encontrarse em um dilema moral, pois não têm resposta técnica adequada e devem lançar mão de sua experiência prática, ou ainda aconselharão com forte conteúdo moral, prescrevendo comportamentos unidirecionalmente.

É a reciprocidade da interação comunicacional que pode dar possibilidade de emergência às questões práticas e colocá-las em debate como uma exigência tecnológica. Posta a usuária como sujeito em relação, pode-se apreender junto com ela a totalidade de sua situação e a particularidade da possibilidade de cuidado e intervenção específica do serviço de saúde, no interior de uma rede de instituições e interações mais ampla. Para isto, é necessário que a autoridade moral do profissional seja questionada como simples decorrência da superioridade técnica e que o mundo do sistema ceda espaço para a lógica do mundo da vida e suas questões práticas. Afinal, em nossa opinião, é a este mundo e a estas questões que a técnica deve servir e subordinar-se, e não ao contrário. 


\subsection{As consultas individuais}

Como já foi dito, as 41 consultas individuais observadas distribuíram-se da seguinte forma: vinte atendimentos de coleta de material para citologia oncótica e exame de mama e sete atendimentos de recepção realizados por auxiliares de enfermagem; oito primeiras consultas de pré-natal e seis primeiras consultas de ginecologia realizadas por médicos.

As discussões sobre sexualidade, reprodução e gênero quase não aparecem nas consultas individuais. Centradas na anamnese e no exame físico, a conversa entre os profissionais e as usuárias é cordial e simpática, mas tem regras bem definidas, em que o profissional pergunta e a "paciente" responde. De acordo com a proposta do serviço, a mulher é orientada sobre tudo o que é realizado com ela. Explica-se o significado dos exames laboratoriais a serem realizados, assim como é cuidadosamente descrito o que é feito no exame de Papanicolaou. No final da explicação, pergunta-se à mulher se aceita fazer os exames ou não. As respostas costumam ser afirmativas e lacônicas. O profissional conduz a consulta, realizando uma série de perguntas para que a mulher responda, e evitando levar a conversa para a discussão de temas não previstos pelo roteiro da anamnese ou para lógicas diversas da biomédica. Para isto, ele deve interromper a mulher, quando necessário, para manter o fluxo narrativo desejado, embora isto seja realizado sempre de forma gentil e educada, após um breve acolhimento da questão trazida, e a mulher concorde, de modo geral imediatamente, em voltar ao assunto proposto pelo profissional. Com este fluxo de diálogo, a interação é bastante instrumental e a possibilidade de ocorrência de relatos sobre o mundo da vida conexos à demanda apresentada é pequeno.

Não que as mulheres não tentem incluir outros temas e abordagens na conversa, e vem daí tal tensão apontada. 
Vejamos o caso da paciente a seguir, que veio ao atendimento de enfermagem porque havia colocado um DIU e estava com atraso menstrual de 16 dias e muito medo de estar grávida. A auxiliar fez o teste, que deu negativo, mas a mulher continua com medo e pergunta se o teste é seguro. A auxiliar responde que sim, que o teste e o DIU são seguros, mas que "em medicina 2+2 nem sempre dá 4, portanto não pode afirmar $100 \% "$

M: ... depois que eu coloquei o DIU, fiz um ultra-som e a médica falou que ele está no local certo ... mas por via das dúvidas ...

Prof: então ... Deixa acabar aqui ...(anotando)

M: tá bom ...

(pausa)

M: na outra encarnação quero ser homem viu ...

Prof: e você acha que homem não tem problema ...

M: ah, mais do que a gente não, viu, mulher sofre para tudo ...

Prof: em compensação a gente tem umas coisas que eles também não tem, né? Umas coisas boas ...

M: (ri)

Prof: por exemplo, amamentar eles nunca vão conseguir, e é tão gostoso ... o teu filho sendo gerado dentro da barriga ... Eles podem fazer junto ... tem sempre uma vantagem ... é só olhar ... às vezes é difícil de enxergar ...

Então, a sua ultima menstruação foi que dia mesmo? ...

M: dia 26 de abril ... de 97.(Atendimento de enfermagem)

A profissional, ao ser chamada a posicionar-se em uma discussão sobre questões de gênero, coloca sua opinião. Submetida a condições de vida semelhante, e trabalhando há muitos anos em serviço de saúde, com saúde reprodutiva, a auxiliar sabe bem o encargo adicional que a maternidade traz para as mulheres. Mas parece preferir diferenciar-se da usuária, fazendo um discurso elogioso do feminino e da maternidade, típico dos serviços de saúde maternoinfantil, e com isto procurando ressaltar a importância do feminino e, supomos, assim buscar "empoderar" a mulher. De qualquer forma, a fala emerge em um intervalo, é escutada, rebatida, e a discussão foi encerrada, voltando a auxiliar para o fluxo da consulta. O espaço para a reclamação sobre a condição de gênero, 
tentado pela usuária, parece ser obstruído, com uma fala elogiosa à maternidade, que não deixa espaço para a tréplica.

O que estamos tentando demonstrar, as condições de interação estratégicas da anamnese em saúde fica evidente em uma outra passagem em que o médico que está realizando o pré-natal sai da sala, e podemos observar a diferença no diálogo com o médico e com a observadora. O médico "conversa" mediado pela anamnese, seu instrumento de trabalho, e a observadora entabula uma conversação aberta, sem propósito tecnológico imediato:

Prof: Corrimento vaginal, coceira por baixo?

M: não, tinha antes ... Depois que comecei a fazer o tratamento ...

Prof: tá, precisou tratar, passar alguma pomada ... Atualmente não tem mais nada?

M: não. Era eu e meu marido que tinha que fazer ...

Prof: certo ... O estômago está bom? Não está com vômito, com dor, nada.

M: não, não sinto nada ... só dor de cabeça assim ...

Prof: os pés estão inchados?

M: ñ̃o ...

( interrupção, alguém bate na porta e o médico sai da sala)

M: foi difícil de vir hoje, que a roupa que eu tenho já não serve, né ...

Pesquisadora: ah, é ... por causa da barriga ...

M: e você não pode vestir roupa apertada, né ... A médica diz que a gravidez não incomoda a pessoa ... mas eu fico com medo. então...

Pesquisadora: de apertar o bebê ... Tem que usar roupa do marido

M: ah, se depender do marido, eu acho que ... sei lá ...

Pesquisadora: por quê?

M: eu acho que ele não quer nem saber ...

Pesquisadora: ah, é?

M: aqueles maridos que querem ser machista ... Sabe, que acha que filho para ele é normal, né. Ele já teve 5 ... perdeu dois ... então para ele é normal. Agora, para mim não, para mim é um pouco diferente ... porque eu nunca fui mãe, a primeira vez ...

Pesquisadora: ahá ...

M: e eu fico com medo ... na hora de vir o nené ... do nené não passar ... tenho medo de ser cesariana ... ou parto normal ... fico meio indecisa sobre o que fazer ... (Caso Novo de Pré-Natal / Rosana) 
Em um diálogo com uma nova lógica, diferente da anamnese médica, a mulher convida a pesquisadora para uma discussão mais ampla sobre a gravidez. A pesquisadora aceita o convite, o que permite o imediato surgimento de questões de gênero. Esta mulher é Rosana, uma de nossas entrevistada e já apresentada aqui. Na sua primeira consulta de pré-natal, que estamos acompanhando agora, o médico pergunta, seguindo o roteiro proposto na ficha de atendimento, se a sexualidade de Rosana tem algum problema relacionado à gestação. Ela fala que está preocupada, pois o marido não está mais tendo relações com ela com a freqüência que gostaria. O médico a ouve por algum tempo, e arrisca uma opinião: diz que talvez o marido tenha perdido a libido por causa da gravidez, que isto às vezes acontece, e que ela deve conversar com ele a respeito. Rosana retruca:

M: É que para ele ... na cabeça dele ... não sei como se diz ... parece que não tem importância ...

Prof: é, mas talvez tenha ... talvez tenha. É que ele não fala para você...

M: então ... eu sei ... Eu tento procurar ... eu faço de tudo ... eu não quero fazer sexo, mas eu tenho isso na minha cabeça ... porque se eu não procurar ele, ele também não vai me procurar.

Prof: certo ...

M: aí os dois ficam em dúvida. Aí eu fico pensando que ele está com outra ...

Prof: aí você já fica pensando que ele está com outra, né ...

M: é ... Uma vez ele saiu ... ele sai 16:30 horas, chega às 16:40 horas ... mas uma vez eu fiquei esperando ... e ele chegou às 2 :30 horas ... e ele não quis falar nada para mim. Só falou para meu cunhado ... que ele tinha ido jogar bola, e que chegando lá tinham convidado ele para ir comer frango no restaurante. Aí eu comecei a discutir com ele, ele começa a me xingar ... ai eu fico quieta, para não discutir, eu fico quieta.

Prof: tá bom ...

(pequena pausa, $P$ está registrando no prontuário)

Prof: já está tomando Sulfato Ferroso, vitamina?

M: não ...

Prof: bom ... deita aí, vamos dar uma examinada em você...

Papanicolau, quando foi a última vez que você fez?

(Caso Novo Pré-natal/Rosana) 
Entre os registros em prontuário encontrados nesta consulta, um deles foi:

Refere dificuldades no relacionamento com o marido

Mas nada foi registrado no campo relativo a diagnóstico e conduta. Rosana tinha diversas queixas, entre as quais algumas que poderiam ser cardíacas, como dispnéia. O médico a princípio relutou em solicitar exames complementares, mas ao final da consulta optou por fazê-lo. Rosana recebeu o pedido para realizar um eletrocardiograma, que resultou negativo, mas foi-lhe importante o suficiente para ter sido citado em seu relato sobre a gestação. O médico, a princípio, acolheu a queixa de Rosana acerca de suas dificuldades no relacionamento com o marido, que emergiu a partir da pergunta da anamnese sobre a sexualidade. Deu sua opinião baseado em sua experiência prática e de trabalho, partindo do suposto de que alguns homens perdem mesmo o interesse sexual na gestação e, portanto, tal comportamento é normal, mas não pergunta a opinião de Rosana sobre o problema. Quando o assunto ruma para a área da infidelidade, por iniciativa da usuária, é rapidamente encerrado e a consulta volta ao seu fluxo habitual. A possível infidelidade é recusada pelo profissional como tema, por não ter projeto possível de acolhimento e resposta e, portanto, não ter sentido tecnológico o seu acolhimento.

É importante relembrar aqui que a anamnese é obviamente instrumento fundamental do trabalho médico e consiste em um conjunto de perguntas que têm um objetivo bem definido: encontrar algum produto potencial que permita recortar um objeto para o trabalho médico. Para isto, ela deve direcionar as falas, sob pena de ser tecnologicamente ineficaz.

Mas, a exemplo dos grupos, qual é o outro extremo deste procedimento? Quando a anamnese se torna um instrumento que passa a dificultar o trabalho, justamente por não permitir a emergência de questões que explicam ou contextualizam a queixa trazida? Qual pode ser a interação tecnologicamente 
eficaz e eticamente boa e justa? Parece-nos que o importante é não perder de vista a inserção social deste trabalho e a finalidade última à qual ele deve servir durante todo o tempo.

Por outro lado, a inclusão de questões sobre sexualidade e/ou violência na anamnese médica corre o risco de reduzir estas condições a patologias ou fatores de risco, que podem vir a ser tratados exclusivamente do ponto de vista biomédico. Parece-nos que colocar o comportamento sexual ou interpessoal sob jurisdição médica desta maneira não aumenta as chances de diálogo público sobre estas situações, nem melhora automaticamente o seu manejo na vida privada das usuárias. Mas conversar sobre este tipo de situação pode ser importante para um melhor raciocínio clínico, sempre que respeitadas as condições de diálogo livre e a autoridade moral da mulher sobre sua vida.

Um atendimento de enfermagem, realizado no dia anterior para esta mesma paciente, Rosana, já ganha um registro um tanto diferente:

Desencontro na relação sexual, ela quer ficar por cima e ele não quer. Quando fiz o teste de giordano (punho percussão lombar) ela pula de dor nas costas, acima da cintura, e diz que o marido dá nela quando ela não quer ter relação, mas ela reitera que ele não bate nela...(Atendimento de Enfermagem/Rosana)

Não há também nada anotado no diagnóstico e conduta deste atendimento, provavelmente porque na interação entre Rosana e a auxiliar ficou indecisa a emergência de violência. Este atendimento não foi percebido pelo médico que a atendeu no dia seguinte, ou não foi levado em consideração, já que não houve menção a ele antes, durante ou depois do atendimento. Rosana foi entrevistada por nós e teve dificuldades para realizar a história de vida. Sua fala é indecisa e ela tem problemas psicológicos importantes. É usuária da Saúde Mental, onde tem o diagnóstico de histeria. Ela faz um uso bastante intensivo do CSE e de diversos 
serviços de saúde. Em quatro anos de uso, fez três primeiras consultas na Saúde Mental (porque abandonou duas vezes e foi reencaminhada), veio a 48 consultas de psicoterapia (12/ano) e, além disto, compareceu a uma média de 4,5 consultas médicas/ano. Durante o pré-natal, realizou ainda mais 13 atendimentos individuais, fez 3 grupos educativos e faltou a 4 atendimentos marcados. Seu prénatal teve mais consultas do que o recomendado pela padronização, porque além das consultas agendadas, ela procurou espontaneamente o CSE muitas vezes. Apesar deste uso intensivo, sua experiência com os serviços de saúde é bastante confusa e ela parece não compreender uma boa parte das instruções recebidas.

Na consulta observada, o médico tentou abordar o assunto das dificuldades familiares de Rosana da forma como foi apresentado, como conflitos nas relações conjugais acerca da sexualidade, mas não há ação técnica prevista. Já a queixa de "falta de ar", por exemplo, é mais facilmente acolhida e recebeu um exame complementar valorizado, por avaliar o coração. Mesmo que o resultado seja negativo, o fato de o médico tê-lo pedido significa que a queixa foi reconhecida como importante, ao menos para ser mais bem investigada e, portanto, foi acolhida desta forma.

Os problemas da vida prática, como os direitos reprodutivos e as relações conjugais, têm maior possibilidade de ser desconsiderados pelos profissionais, principalmente quando estes não vislumbram possibilidade legítima de intervenção sobre o "caso".

Em outra das consultas observadas, também havia relato de violência no prontuário, que desta vez foi lido pelo médico antes do atendimento. A consulta era um atendimento com o ginecologista para a colocação de DIU em uma mulher após o parto. O relato encontrado era de três meses atrás, durante o pré-natal:

Muitos problemas em casa. Relacionamento violento com marido; brigas com facas, jogam água fervendo um no outro. Paciente 
teve 3 gestações, nenhuma planejada, depois do segundo filho tentou pôr DIU e não conseguiu, pois engravidou antes. Fala que tentou abortar o terceiro, não conseguiu, agora quer por DIU, mas está com medo de engravidar antes novamente.

Diagnóstico: violência doméstica/ miséria social - dificuldade social

Conduta: orientar registro e matrícula das crianças.

(Atendimento médico - Pré-Natal)

O profissional médico que ia atender a mulher assinalou que tinha visto o registro, mas não iria abordar o problema, porque não the parecia adequado. $\mathrm{Na}$ sua opinião, seria uma intromissão indevida na vida da mulher, já que não poderia fazer nada a respeito desta situação. Chama a atenção que, apesar da conexão do problema-violência da forma como descrito no prontuário com a atividade de contracepção observada, já que a mulher havia dito que tinha muito medo de nova gravidez indesejada, o profissional ativamente declare que não levaria em conta o problema em seu projeto de trabalho. Vejamos um trecho desta consulta:

Prof: quando você tosse, espirra, faz esforço, escapa urina sem querer? Perde urina?

M: não.

Prof: a primeira relação que você teve, tinha que idade?

M: $16 \ldots$

Prof: você está usando o quê atualmente para evitar gravidez?

M: camisinha ...

Prof: está usando em todas as relações, isso é importante, em todas as relações, tá? O que você já usou anteriormente para evitar gravidez?

M: pílula ...

Prof: pílula ... mas agora, depois do parto não ...

M: já usei também ...

Prof: usou Micronor é isso? Quanto tempo você usou Micronor?

M: usei dois meses. usou?

Prof: ... e em outras épocas você usou outros comprimidos, o que você já

M: usava comprimidos ...

Prof: qual você usava? 
M: Neovlar...

Prof: usou quanto tempo? Se for juntar todo o tempo que você tomou, quanto tempo você tomou o Neovlar?

M: 8 meses ...

Prof: 8 meses no total, Neovlar. E agora, desculpe insistir na pergunta, você está usando camisinha em todas as relações ...

M: estou ...

Prof: você mora com seu marido?

M: moro ...

Prof: mora com ele ...E sua primeira menstruação foi com que idade?

M: 14. (Caso Novo de ginecologia)

O DIU não foi colocado neste dia, porque a fase do ciclo menstrual não era adequada. Assim, a consulta foi remarcada para um outro dia no próximo mês. Neste momento, o profissional reforça o uso de camisinha:

Agora, vou explicar uma outra coisa para você ... você vai entender. É importante que continue usando a camisinha. Se você chegar aqui e falar - ah, antes de ontem tive relação sem camisinha ... -, aí eu vou marcar um outro dia para você ... Então não faça. Primeiro que você pode engravidar. Segundo que atrapalha a colocação do DIU, cuidado, tá? O marido aceita usar camisinha? ...

M: aceita ...

PROF: tá bom ... Então, dia 9 ... é uma terça feira de tarde, às 17:30,

Perguntada se tinha alguma dúvida, a mulher diz que não. Apesar de dizer que não há problemas em usar camisinha e que a usa constantemente, o registro em prontuário durante o pré-natal aponta para suposição de que pode haver dificuldades para que ela consiga fazer o prometido. Ela tem medo de engravidar novamente antes de colocar o DIU, provavelmente porque deve ter dificuldades de controlar a própria sexualidade. Parece-nos que a condição de interação na consulta foi impermeável à emergência desta dificuldade, ainda que tenha sido educada e correta do ponto de vista estritamente técnico.

Não lhe foi perguntado por que estava com medo de engravidar de novo nem o que havia acontecido na gravidez anterior, nem ela expressou qualquer comentário neste sentido. A forma de perguntar sobre o uso de condom também deixa pouca margem para uma resposta negativa. Dada a diferença de poder na consulta, depois de ouvir o médico sobre como é importante este uso, se a mulher 
responder que não, estará confessando sua falta de cuidado com a própria saúde, já que a responsabilidade deste uso parece ser exclusivamente dela, na sua relação privada com o marido. Não se está afirmando aqui que as mulheres não podem dizer não em tal contexto discursivo, mas que há um constrangimento que dificulta o aparecimento dos problemas práticos da vida, ao mesmo tempo em que ironicamente é este mundo que está sendo transformado (ou reproduzido) pelo trabalho.

Na saída da consulta, esta mulher comentou com a observadora que na última gravidez havia acontecido o mesmo, o DIU havia sido adiado e ela havia engravidado. A dificuldade para a expressão destas questões na consulta médica pode diminuir a efetividade concreta do serviço, que foi permeável, a princípio, ao problema, registrando em prontuário o conflito e propondo até uma resposta, o registro e matrícula das crianças na escola. Mas, na próxima consulta, fechou a possibilidade de escuta, com base na premissa de que não pode fazer nada sobre o problema-violência. Assim, o serviço perdeu a oportunidade de colaborar mais na garantia dos direitos reprodutivos desta mulher. Aqui, fica claro o sentido tecnológico da interação no trabalho, tanto entre os diversos profissionais, por meio da comunicação entre eles com vistas ao desenvolvimento do trabalho em uma direção comum (PEDUZZI, 1998), quanto entre o profissional e a usuária. Considerar a dimensão dos direitos reprodutivos é essencial para o sucesso do trabalho aqui.

Note-se que o médico abordou a questão do uso da camisinha insistentemente e que a mulher afirmou o seu uso consistente e o fluxo proposto, não levantando objeções e dizendo que não havia problemas. Parece-nos que as condições discursivas não deixaram espaço para a mulher expressar as mesmas preocupações colocadas durante o pré-natal, ainda que o profissional tenha sido cordial e atencioso. Se esta mulher engravidar novamente, a responsabilidade será dela, pois não cumpriu a sua parte no acordo: usar camisinha em todas as relações 
sexuais. Assim, o profissional desresponsabiliza-se pelo cuidado sem perceber, mantendo as dificuldades da mulher com a contracepção fora do escopo de seu trabalho.

Em nossa opinião, isto se dá porque a finalidade de trabalho deste profissional neste momento é a colocação do DIU, procedimento para o qual é tecnicamente competente. Ele não inclui em seu objeto de trabalho e, portanto, na finalidade pretendida, atender à necessidade objetiva e expressa da mulher de não engravidar novamente, mas apenas responsabiliza-se pelo procedimento de colocar o DIU, realizando os melhores procedimentos técnicos para isto.

Claro que o profissional almeja também que a mulher não engravide sem querer, mas não se sente em condições de contribuir para isto além do que já faz, não encontra uma forma disto fazer sentido no seu trabalho. Como a dificuldade no exercício dos direitos reprodutivos é percebida como uma questão exclusivamente da mulher e da sociedade, o médico, em uma posição neutra, não inclui esta dificuldade em seu projeto de trabalho, considerando-se neutro em relação à "sociedade", já que não pode intervir diretamente sobre ela .

Obstáculo a uma interação efetivamente comunicacional e seus efeitos em termos da efetividade do trabalho realizado aparece também em outra situação observada, a propósito da coleta de Papanicolaou.

\subsection{A coleta de Papa}

A coleta de Papanicolaou é um dever introjetado nas mulheres, nas últimas décadas, por campanhas de educação em saúde e oferecimento massivo nas consultas individuais de ginecologia. Ele é um exame barato, simples, potencialmente indolor e eficaz para reduzir em muito a mortalidade por câncer de colo uterino. 
A observação desta atividade nos trouxe novas questões acerca da articulação da interação comunicacional no trabalho. Todas as profissionais explicam como é feito o exame e para que serve, e tratam de interagir com a mulher, mas a permeabilidade desta interação à dimensão comunicacional é diversa. Classificamos o observado em dois pólos extremos de interação:

condições de interação pouco permeáveis: algumas consultas foram focalizadas o mais estritamente possível na coleta de material citológico e auto-exame bem realizado, e

condições de interação permeáveis: outras consultas propiciaram um acolhimento maior e maior preocupação com a vergonha e o medo das mulheres quanto ao exame a ser realizado. Também propiciaram um maior espaço para expressão de demandas não relacionadas especificamente ao exame.

Em nossa observação, a permeabilidade da interação foi importante para que o exame fosse realizado sem dor ou vergonha, em um clima de respeito mútuo. Esta questão é básica no exame ginecológico em geral, que pode ser uma experiência de vergonha e dor para as mulheres. Isto chama atenção, porque potencialmente o exame não precisa gerar dor, ao menos para a maioria das usuárias. Pelo caráter massivo necessário para sua eficácia técnica, parece-nos que sua realização respeitosa, levando em conta a usuária como sujeito, seja uma questão tanto de direitos humanos como de eficácia sanitária, em termos da aceitabilidade necessária para programas de screening.

Os momentos menos permeáveis são aqueles em que a auxiliar está preocupada unicamente com a eficácia estratégica do procedimento de coleta e tem como objetivo estrito coletar o material para o exame citológico. É interessante a forma como esta compreensão relaciona-se com o entendimento de sua responsabilidade no trabalho:

Prof - Então é assim, a gente vai colocar um espécul. .... Vai doer se você 
ficar rígida, dura e contrair os músculos, daí dói. Se ficar relaxadinha, tranqüila, não dói nada, já ficou dura, já tô vendo...tá bom, tá bom?

M Tá bom.

Prof- $50 \%$ é teu e os outros $50 \%$ é meu. A minha parte eu posso fazer, é a parte técnica da coisa.

M: Fechado.

Prof: Fechado! (Coleta de papanicolaou pela enfermagem)

Para esta profissional, os seus 50\% resumem-se à parte "técnica". Apesar de ser o próprio serviço que divulga ativamente a necessidade de realização do exame, esta profissional não se sente responsável por cuidar da mulher e ajudá-la a relaxar. Para ela, seu trabalho é apenas colher o material, e não cuidar da mulher. Ela não se preocupou também com a privacidade e a vergonha da usuária, não oferecendo um lençol para ela se cobrir. Na sua fala, a parte técnica ela faz, e se o exame doer a culpa é da mulher, que não fez adequadamente sua própria parte: relaxar. A auxiliar busca ajudar a mulher para que relaxe, dando pequenos tapinhas na perna, ou pedindo para a mulher fazer de conta que não tem a parte de baixo, mas seu tom e sua postura não são nada acolhedores. As coletas deste tipo são realizadas em silêncio, ou com gritos de dor.

As observadoras anotaram as seguintes expressões das mulheres durante coletas deste tipo:

O rosto de pavor durante o exame, os dentes cerrados com os olhos cheios de lágrima e imóvel na cama(coleta 1).

Paciente fica tensa, a respiração é ofegante, dispnéia. Paciente mantém olhar fixo em algum lugar no teto. O Silêncio é grande (coleta 2).

Registros que nos impressionaram por mostrarem limites importantes na interação, que, quando puramente estratégica, anestesia-se para a percepção do outro a ponto de cenas como esta serem comuns, como acreditamos que sejam, nos serviços de saúde espalhados pelo país. Estas pacientes estão voluntariamente submetendo-se ao exame, que a principio é para o seu bem, bastante aceitável e 
ativamente divulgado pelas instituições de saúde. Mas a experiência, algumas vezes, parece de terror.

Timidamente, as mulheres dão o troco. Duas delas, ao terminar exames deste tipo, contam que fizeram o mesmo exame no mesmo serviço no passado e não sentiram dor como desta vez. Em nossa opinião, elas querem afirmar que desta vez doeu não por culpa dos 50\% delas, mas por responsabilidade da profissional. A auxiliar, por sua vez, busca explicar para a mulher o que ela deve fazer, já que não tem mais nenhum recurso técnico para ajudá-la na experiência do exame.

Será que realmente o serviço não tem mais nenhum recurso para tornar um procedimento de rotina uma experiência interativa sem tanta dor e medo? A possibilidade de participar da decisão e da realização do exame ginecológico exige a presença de dois sujeitos ativamente em busca de um projeto comum (a realização do exame) e não dois sujeitos se acusando mutuamente e culpabilizando apenas o outro como responsável pela ação conjunta.

Parece-nos que há possibilidades, pois no pólo mais permeável, outra auxiliar lida com o mesmo problema da tensão no exame de forma bastante diversa:

Prof: Esse aqui é o espéculo, abre lá dentro.

M -A última vez que eu fiz não doeu, mas toda a vez que eu faço dói. E hoje vai doer mesmo.

Prof- Não, M...

$M$ - Hoje eu não sei.

Prof-Se caso doer, tudo bem. Se você prende a musculatura, você fica ansiosa, com medo, você prende a vagina. Dói mesmo, se a gente forçar, vai doer. Muitas vezes a gente conversa... mas, a gente não vai enfiar, forçar né. Porque ai a pessoa vai ficar com uma idéia ruim do Papanicolau.A gente tenta não tá fazendo isso. Se você perceber que está doendo muito, se preferir fazer em um dia em que estiver melhor da coceira, aí a gente desiste e marca outro dia. Tudo bem.

M-Tudo bem. Mas a pessoa fica mais pensando no Papanicolau, né?

(Coleta de Papanicolaou - enfermagem) 
Esta profissional foi mais cuidadosa e colocou para a mulher a possibilidade de não ser examinada naquele dia, podendo marcar para outra data. Mesmo assim, ela resolveu fazer o exame, e sua experiência foi bastante tranqüila. Nestas consultas também houve preocupação com a privacidade da mulher e foi providenciado lençol para ela se cobrir, evitando expor sua nudez e. No lugar de $50 \%$ responsável, aqui a profissional parece sentir-se $100 \%$ responsável pela relação, que só pode ser comunicacional com o compartilhar de dois sujeitos. A usuária também é chamada a responsabilizar-se 100\% pela relação. Nesta abordagem mais "permeável", a profissional compreende o cuidado como parte de seu trabalho (se você sentir dor não vai mais querer fazer o exame), e trata de buscar um encontro com a pessoa que está assistindo, abrindo para ela até a possibilidade de recusar o procedimento, deixando em segundo plano a coleta propriamente dita naquele dia. Já a primeira auxiliar penaliza a mulher por não relaxar e, na sua concepção, atrapalhar o seu trabalho, concebido como a coleta tecnicamente bem realizada em termos da qualidade da lâmina obtida.

A última profissional está utilizando a lógica sanitária da cobertura para avaliar o seu trabalho, fazendo um uso também estratégico da dimensão comunicacional. É importante que a experiência do exame não seja muito ruim para que a mulher possa voltar nos próximos exames agendados durante a sua vida, e é também por isto que respeita a mulher como um sujeito integral, discutindo com ela a necessidade e os obstáculos ao exame. Obviamente tanto o cuidado como a boa técnica de coleta são fundamentais aqui, e não se trata de escolher entre um e outro. $\mathrm{O}$ fundamental é perceber como os direitos humanos e a saúde pública podem se encontrar, deste ponto de vista, de forma convergente no contexto das ações em saúde tal como definidas pelo PAISM. E, também, como a interação puramente estratégica e "neutra", que trata o corpo do outro como um objeto que deve "colaborar", pode ser contraprodutivo ao cuidado de todos os pontos de vista, incluindo o biomédico. 


\subsection{A vagina larga: relações de gênero e sexualidade medicalizada}

Assim como os profissionais de saúde tendem a concentrar seu trabalho na anamnese e nos procedimentos instrumentais sobre o corpo, limitando-se ativamente ao campo biomédico, as mulheres também trazem seus problemas aos serviços já traduzidos nesta mesma linguagem da doença. Mas esta tradução nem sempre é eficaz em termos de traduzir o sofrimento e buscar uma ajuda efetiva, já que para os profissionais este deslocamento discursivo pode acabar por desqualificar a queixa trazida.

Uma outra consulta observada permitiu o aparecimento de questões relacionadas a um contexto de violência (dor na relação sexual). Trata-se de uma coleta de Papanicolaou. A mulher que estava se submetendo à coleta passou mal, teve náuseas e desmaiou, não podendo ser realizado o exame. Após o episódio, ela foi ouvida pela observadora de campo, que era psicóloga, que registrou o seguinte relato:

Ela disse que desmaiou e foi até sua casa onde estava conversando com sua mãe num jardim com muitas flores. E a última coisa que lembra é de ter um aparelho grande (e fez um gesto com a mão. Mostrei a tesoura, e ela disse que foi isto a última coisa que viu). Pensou que a profissional fosse furá-la, machucá-la (como quando tinha relação com o marido).

Depois de conversar bastante com ela, começou a contar com muita angústia, e chorando, a situação. Está separada de seu marido e voltou com um antigo namorado que foi sua primeira paixão.

Conta que se separou desta paixão, porque a mãe dele não permitiu o namoro, tinham 17 anos. Depois conheceu este outro rapaz com quem morou 
junto. Conta que mantinha relação sexual com ele, mas não sentia prazer. Ela relata que o companheiro tinha um pênis muito grande e a machucava.

Acha que ficou larga, e agora que voltou com o antigo namorado, ele fala que sua vagina está muito molhada e larga. Porém relata que sente muito prazer e fica muito excitada com o namorado atual, e que goza antes dele. Isto está lhe provocando muita angústia, pois acha que por estes motivos ele pode deixá-la novamente.

Conta que quando está sentada sente um vento entrando, isto comprova, segundo ela, que está larga. E gostaria de uma operação para costurá-la.

Disse que tem vergonha de contar (que está larga), mas que veio disposta a falar para alguém no C.S. (Relato de campo)

Esta queixa de "vagina larga" não é incomum. Além de ter sido citada nas entrevistas individuais pelas duas auxiliares de enfermagem como queixas relacionadas à violência, outra paciente observada, Maria da Penha, relatou queixa semelhante em um grupo. Com as condições de fala mais ampliadas, ela pode expor melhor sua visão do problema que enfrenta e as possíveis soluções que antevê:

M: Eu vim até aqui pelo seguinte, porque eu acho... eu tenho certeza que ... eu tenho 3 filhas, ... as 3 são normais e da segunda minha menina eu ganhei lá no Hospital... e eu tenho, não sei, meu marido também vive reclamando porque eu tenho a... a vagina muito aberta, entendeu? E... eu gostaria de ver se tem alguma coisa, sei lá, alguma coisa que possa... acho que isso não é normal numa mulher. Ele sente que está, que a vagina está aberta, inclusive ele fica falando para mim porque que eu sou assim e muito molhada também, tá... e eu gostaria de ver o que que eu poderia fazer para, sei lá, para fechar, costurar, alguma coisa assim para que ele se sinta melhor, eu também me sinto mal. Porque você sabe, os homens, eles ficam desconfiando, ficam falando isso, aquilo, às vezes não é nem isso aí, não tem nada a ver, então eu vim, eu gostaria de ver o que que é, o que poderia fazer e também gostaria muito de fazer o Papanicolaou porque estou sentindo uma dorzinha na minha barriga, corrimento eu não tenho. (...) 
Prof - Isso é uma coisa que incomoda você ou incomoda ele só?

M - Incomoda a mim também, porque você sabe, se você vai dormir com o seu marido, seu marido fala: bem, você está frouxa, o que que está acontecendo com você? Então você se sente uma mulher assim, sabe. Se você não deve, claro vocêe está com a sua consciência tranquila. Agora se você sai assim... eu saio tal dia com outro e ele tinha algum negócio mais gostoso, aí tudo bem. Então você fica naquilo, mas você não deve, a tua consciência está tranquila.

Eu não sou normal, meu marido não é esses homão grande, ele é normalzinho e eu não vivo assim... eu não sou uma mulher... está todo mundo aqui, mas eu tenho que falar... Sabe o que meu marido falou para mim? Falou: ó bem, sabe o que você faz? Eu vou fazer o seguinte, eu vou marcar meu negócio aqui num cordão e você fala para o médico assim: o tamanho da minha mulher é isso. Aqui é tudo mulher, eu vou falar. Eu falei: então, bem, me dá porque eu vou fazer isso para mim levar, porque não me deixaram normal (no parto). Eu vou lá, vou ver, porque o problema meu é que a gente fica mesmo assim, nervosa, que é um negócio chato isso aí. Eu não queria ser assim, mas infelizmente eu sou, que que eu posso fazer? Então se eu puder, se tiver alguém que se interesse pelo meu caso, se puder me ajudar, se tiver que fazer alguma coisa, uma cirurgia, uma períneo, não sei como é que faz, mas que eu não fique desse jeito, que eu me sinta melhor. É isso que eu tenho para dizer é isso. (Grupo de Recepção/Saúde da Mulher, Maria da Penha)

A queixa de vagina larga é emblemática. Ao transformar conflitos relativos à sexualidade em uma reclamação "anatômica", as mulheres e homens podem solicitar aos serviços de saúde a resolução destes conflitos pelo conserto no corpo (uma cirurgia para fechar a vagina). Exemplo claríssimo de medicalização, isto é possível porque a medicina realmente trabalha repondo necessidades sociais vividas no mundo da vida por meio de intervenções sobre o corpo biomédico, como visto. A população conhece a perineoplastia, cirurgia que justamente corrige alterações anatômicas do períneo. A esperança de encontrar uma resposta na prática médica para a satisfação de conflitos na esfera da sexualidade leva as mulheres que estão convencidas de ter a vagina larga a buscar a reparação prometida pelos serviços de saúde. As mulheres observadas parecem perceber que a "largura da vagina" é conexa à infidelidade real ou suspeita, presente ou passada. Em nossa concepção, é por isto que a primeira mulher tinha vergonha de falar sobre o problema, o que fez com que remetesse ao serviço, a princípio, a 
demanda por Papanicolaou, queixa mais legitimada. Maria da Penha também agrega à sua demanda o pedido por Papanicolaou. Mas, ao mesmo tempo, elas imaginam que o serviço de saúde pode resolver o seu problema (a acusação de infidelidade) pela manipulação do corpo. A vagina larga é algo que denigre a dignidade da mulher, pois insinua que ela não garante a exclusividade sexual do marido, base da honra feminina. Submeter-se à períneo pode, no entender destas mulheres, fechar sua vagina e refazer a interação com o marido, cessando assim a suspeita ou acusação.

A insinuação de que a vagina pode ficar " larga" por ter relações com outro homem, que não o atual companheiro, é colocada explicitamente nos dois casos. A primeira, porque teve relações com um homem antes do companheiro atual, que tinha "o pênis muito grande". A segunda, porque o marido fica desconfiado da fidelidade dada à "largura" de sua vagina, ao que ela retruca que é injusto, porque "não dá motivos, não sai, nem tem outros homens". As duas remetem o conflito, instaurado no controle da sexualidade feminina, para uma resolução literalmente mecânica nos SS . A última mulher chega a explicitar a vontade do marido de que o "conserto" deixe a vagina dela "sob medida" para ele.

Os profissionais não podem responder a estas demandas, porque elas não fazem sentido do ponto de vista do saber biomédico. Ao exame ginecológico, nenhuma das duas apresenta as alterações anatômicas que seriam necessárias para o diagnóstico de anormalidade, ou doença, e, portanto, que merecesse qualquer intervenção. Estas mulheres se percebem anormais, mas não o são para o saber profissional. O problema não pode ser reconhecido pelo saber biomédico, já que não se encontra onde é procurado, na anatomia da vagina.

Como vimos, entretanto, o saber operante não é apenas uma aplicação direta do saber que está nos livros. Os profissionais relativizam, em seu trabalho, a aplicação deste saber pela sua experiência. Esta mulher não inventou a queixa ou a 
solução antevista (períneo), para provocar os serviços de saúde. Ela ouviu a indicação terapêutica, ou pelo menos assim ela a entendeu, de um médico. Este outro profissional, em outro serviço, teve uma interpretação diferente do exame físico realizado, baseado em sua experiência, e tomou uma atitude diversa do ginecologista do serviço observado (que não encontrou alterações anatômicas nestas duas mulheres), e possivelmente não amparada pelo saber técnico-científico. Provavelmente, com o objetivo de "livrar-se" da queixa inconveniente, que seu saber prático deve saber freqüente, deu para a mulher uma explicação e possível solução para o problema, sem no entanto indicar-lhe o caminho para acessar concretamente a resposta acenada. Como o relato foi aquilo que a paciente compreendeu, não podemos saber em que medida corresponde às palavras do profissional. Nas palavras da mulher:

Aí outro médico, conversei com ele, aí ele examinou direitinho, aí ele falou para mim. O que você tem, você tem um probleminha que a maioria das mulheres tem, você precisa fazer períneo. Eu falei: mas o que que é isso perine, Dr. Ele falou: é o seguinte é que você é um pouco, um pouco... ele falou lá no nome dele. A conta da mulher é 2 dedos (ele era um negão, altão): eu botei 3 e se entrar os 4, entra. Tudo bem, e se entrar uma mão forçada, entra, mas aí que tem o problema, o motivo de entrar uma mão ou sair. Quando a gente vai ter um filho tem que abrir mesmo o normal para sair a criança. Agora uma coisa, que é normal de um pênis de um homem, do marido nosso, então eu acho que tem aquele normalzinho assim. Ele falou para mim que eu teria que fazer mesmo a perineo, fazer essa cirurgia. Então eu estou procurando alguém que possa me ajudar a resolver o meu caso, porque não é todo mundo que se interessa, não é, para ajudar as pessoas? A gente não pode pagar, particular a gente não pode, então eu estou aí (Saúde da Mulher).

Esta mulher solicita insistentemente uma resposta bem delimitada do serviço, que não pode responder a este apelo, pois não tem respaldo técnicocientífico, nem pode abordar a infidelidade e os valores envolvidos. A médica presente ao grupo limita-se a explicar a normalidade anatômica desta mulher. Maria da Penha foi encaminhada para o ginecologista e para a saúde mental. O registro da primeira consulta nesta atividade trazia a seguinte anotação:

... fala da filha mais velha com a qual não se entende, não bate e nem pede para ela fazer nada em casa, "ela é muito ignorante 
comigo" ela também não se dá bem com o pai, uma vez teve polícia na minha porta por causa de briga entre ela e o pai. A paciente está muito mais preocupada hoje com o marido que bebeu ontem. Ele bebia muito, mas parou porque ela põe remédio na comida dele. Fica preocupada em que estado ele vai chegar em casa. ... a paciente teve um caso com outro homem e o marido a viu beijando este homem no rosto. ... fala de quantas vezes desejou que ele morresse e hoje se arrepende por ter pensado isso, mas quando ele bebe ele diz coisas horríveis, magoa todo mundo (Dinâmica Familiar/Saúde mental)

Para discutir a queixa de vagina larga, a única opção do serviço seria abordar a infidelidade (no caso, cometida pela mulher, o que traz ainda mais dificuldades de abordagem) e as dificuldades familiares, deslocando-se do discurso competente do corpo. Seria necessário trabalhar os valores envolvidos e a conexão destes valores com as queixas apresentadas, respeitando-se a autonomia da mulher. Mas que espaço pode ter esta conversa no interior da assistência? Sem um saber que sustente um projeto de trabalho para o problema, o serviço opta por obscurecê-lo, tanto ao confirmar a queixa como doença, como ao negá-la como tal.

A possibilidade de interação comunicacional que coloque em discussão a infidelidade, os problemas conjugais, os padrões culturais e sua relação com a queixa ficou afastada. Esta seria a perspectiva que possibilitaria o acolhimento e resposta do problema sem o "disfarce" da doença. Esta possibilidade parece estar bastante obstaculizada na consulta médica, por suas características próprias de atuação, ainda que não seja impossível. Os grupos parecem ser os espaços mais permeáveis a este tipo de diálogo no CS observado, ainda que também com muitos obstáculos, como veremos.

\section{Os grupos}


Os grupos, conduzidos em sua maioria por auxiliares de enfermagem (apenas os de recepção ao programa foram conduzidos por uma médica e uma psicóloga), foram espaços permeados de falas acerca de questões relativas a gênero, sexualidade e reprodução. De uma maneira geral, percebemos que o discurso das agentes da instituição é realmente ancorado no PAISM. As falas institucionais estimulam o conhecimento do corpo, o direito ao prazer e a participação masculina na contracepção. O diálogo é instigado como estratégia para a conquista destes objetivos. Entretanto, o diálogo interno ao grupo nem sempre flui. A fala institucional tem mais peso, mais tempo e coordena o grupo, dando e retirando a palavra. Há um estímulo perceptível para a expressão das usuárias, mas a instituição acaba sempre com a palavra final, em falas mais longas e conclusivas para cada tema abordado.

As usuárias, encontrando um maior espaço de fala, resistem, concordam, defendem, silenciam, desafiam, contrapõem, questionam. Ao falarem de sua educação, sua relação com o corpo, suas negociações com os homens e sua interação com os serviços de saúde, elas falam, no estreito espaço que encontram, de um mundo da vida que não se 'encaixa' exatamente nos modelos que o serviço pode incorporar. Isto ocorre por falta, reducionismo, quando o modelo é estritamente o biomédico, situação em que o serviço, quando ouve e acolhe o problema - o que não é comum, - não oferece qualquer solução nesse plano do mundo da vida.

Por outro lado, quando o modelo busca escapar do reducionismo biológico (como é o caso do pretendido pelo PAISM e pela instituição estudada), o mundo da vida parece também não conseguir penetrar as relações que se dão no serviço - já que as profissionais parecem buscar um tipo idealizado de sujeito que exige atos e comportamentos jamais pretendidos pelas usuárias, porque significam atos de subversão total do que valorizam e querem para si como mulheres em relação com seus parceiros. Assim, há dificuldades muito concretas à proposta resolutiva 
oferecida pela instituição e pelo PAISM, paradoxalmente quando há uma tentativa de resposta por parte do serviço. A nosso ver, isto se dá porque a proposta de resolução é pouco relacional, partindo de um modelo de comportamento proposto unilateralmente pelos técnicos, ainda que baseados em ideais do movimento organizado de mulheres. Ao mesmo tempo, as auxiliares de enfermagem compartilham com as mulheres diversas dificuldades do mundo da vida, por terem uma inserção de gênero e camada social próximas, e precisam manter a diferenciação de sua identidade profissional sempre presente para a ação tecnológica.

Notamos um movimento de cisão e reunificação entre as mulheres presentes ao grupo. Quando falam sobre os homens, as mulheres observadas tendem a um só coletivo: perante este Outro - os homens -identificam-se com um mesmo feminino que estranha o Outro e tendem a reconhecer-se como iguais. Mas, quando se trata de afirmar o feminino, exercerem a si mesmas como mulheres sujeitos-sociais, fazem dividir o Feminino (coletivo) e estranham-se entre si, dividindo-se em mulheres profissionais e mulheres usuárias, com discursos por vezes bem distintos. Buscamos aqui este movimento de cisão e reunificação, o que mostraremos quando 'mulheres cuidam de mulheres' e 'mulheres falam dos homens', como os dois segmentos a seguir, enquanto as situações de violência serão analisadas na última parte, em 'mulheres e violência: o trágico na situação de gênero'.

\subsection{Mulheres cuidam de mulheres}

As profissionais da saúde fazem um discurso acerca do corpo que estimula insistentemente o autoconhecimento. As mulheres devem conhecer e tocar suas mamas, e é oferecido um espelho no exame de Papanicolaou para verem seu colo do útero. Conhecer e tocar o colo também é necessário para o uso do diafragma, e é 
estimulado para o controle do DIU pela paciente. Além da anatomia, é ensinada também a fisiologia do aparelho reprodutivo feminino, com ênfase no período fértil e no muco ovulatório, que também deve ser percebido. Chama a atenção na fala das agentes o uso constante de diminutivos e simplificações, infantilizando o discurso com expressões como: bichinho, furinho, coisinha, asinha e outras parecidas. Estes diminutivos acabam por desqualificar o interlocutor, mulheres adultas visivelmente tratadas como crianças que não sabem. Não queremos aqui ser românticas e negar a importância da democratização desta informação. $O$ aprendizado da linguagem biomédica do corpo, que acontece nas atividades do serviço, pode ser bastante importante para o controle das mulheres sobre sua saúde e sobre o uso de serviços. O que percebemos é que diversas vezes o convite a se conhecer transforma-se em nova prescrição, e não em um convite:

"Vocês lembram que a gente examinou as mamas. Todo mundo examinou as mamas depois em casa?" "Eu não." "Não falei pra todas que era pra fazer isto em casa? (tom de bronca). Não falei que era vocês mesmas que tinham que cuidar do corpo de vocês?" (Resultado de Papanicolaou)

Uma parte das usuárias discorda frontalmente da idéia de se olhar ou se tocar. São mulheres que têm nojo, expressam repugnância, acham o corpo feio, ficam surpresas, não querem nem pensar nisto: "Mulher só é bonita de pé". Defendendo a tradição, elas recusam as novas propostas. Outras, a minoria, entusiasmam-se com as novas possibilidades colocadas, ou já as conhecem e querem se aperfeiçoar. De uma maneira geral, há uma certa desconfiança para com a oferta da oportunidade de cada uma 'ser o seu próprio médico'. Quando a participação no cuidado é oferecida, as mulheres tendem a rejeitá-la, já que esse papel não é visto nem como parte da experiência feminina, nem como parte da experiência de 'leigos' da Medicina. A recusa, neste caso, pode ser vista como resultado dessa soma, mas, de qualquer forma, distancia a mulher da profissional que a oferece. O convite a olhar e tocar o próprio corpo parece suspeito, por pretender passar a responsabilidade de escolher o certo e o errado, o normal e o patológico, para as mãos da própria examinada. Impossível deixar de ver nisso a 
cumplicidade complementar necessária à tão aceita relação assimétrica com as profissionais.

Estas, por sua vez, incorporam autenticamente o dever ao empoderamento, mas em moldes tão técnicos, como o faz o próprio PAISM (D’OLIVEIRA, 1996). E isto pode levar, muito freqüentemente, ao tratamento estratégico também das dimensões comunicativas na interação, uma vez que a emancipação e a liberdade decisória das mulheres usuárias, que as profissionais pretendem inserir como um valor a ser exaltado, torna-se quase uma ordem técnica do serviço (tal como "seja livre). É preciso cuidado no sentido de não se resvalar na análise para falácias de cunho demagógico: não se pode ignorar a diferença de saberes - o da experiência científica e o da experiência da vida. Alerta-se tão somente (o que politicamente não é pouco), para a quase imperceptível (do ponto de vista cultural) transposição da autoridade técnica em autoridade moral, que impede o exercício de escolhas pelo sujeito 'dominado'. Isto sem dúvida torna complexa a proposição ética do PAISM e difícil seu exercício prático; contudo, não desqualifica a investida política de tentar o encontro da técnica com a ética da emancipação.

Em relação aos métodos contraceptivos, as mulheres reclamam com veemência da insegurança e efeitos colaterais dos métodos disponíveis. Mencionam a pílula (ACO) como causadora de inúmeros males, incluindo até uma 'massa' que se acumula no útero, necessitando de curetagem; o DIU como causador de hemorragia, dor nas pernas e câncer; e o diafragma como objeto artificial, extremamente esquisito e trabalhoso. A eficácia do DIU e do diafragma também é muito questionada. Além disto, as mulheres dizem que "tabela não funciona, camisinha os homens não usam", nem vasectomia, e até a laqueadura, única opção mais segura, "pode desfazer". As mulheres parecem bem insatisfeitas e inseguras com as possibilidades de escolha disponíveis. As queixas relativas aos métodos são incisivas, fazendo com que as usuárias desafiem as profissionais quando estas tentam contestá-las. Chegamos a ouvir relatos de mulheres que 
afirmavam ter "visto a massa de pílulas em um exame de ultra-som", ou de afirmarem conhecer mulheres que "retiraram várias cartelas de pílulas em curetagens".

As profissionais, por seu lado, ciosas de seu saber, enfrentam o questionamento que elas mesmas provocaram, ao abrir espaço para a fala. Mas o fazem menos pelo diálogo entre diferentes concepções femininas acerca do planejamento reprodutivo e do corpo - para o que trabalham positivamente as distintas imagens do recurso de contracepção disponível, mantendo a identidade de mulher - e mais pela desqualificação do saber prático diante do científico. Permitem alguma expressão das concepções das usuárias, mas depois têm longas falas acerca de anatomia e fisiologia do aparelho reprodutor feminino. Buscam desfazer o que chamam "mitos" ou "fantasias" que obstaculizam o caminho da compreensão da verdade anátomo-fisiológica e sanitária (ainda que bem simplificada, dadas as condições da cena de encontro entre elas). Defendem, em maior ou menor grau, a eficácia e a segurança de todos os métodos, especialmente do DIU. São estimulados também o condom e o diafragma. Pouco dizem sobre o que elas próprias usam, como experiência de vida com estes métodos, e também pouco tematizam as diversas experiências das usuárias com a contracepção, de forma positiva, aproveitando o saber acumulado da experiência, mesmo que fracassada, das usuárias presentes, ou buscando, de alguma outra forma, fazer dialogar abertamente o saber biomédico e o prático.

O grande desafio das profissionais no grupo é convencer as mulheres de que é possível controlar a capacidade reprodutiva por meio de recomendações técnicas. Enfrentam uma verdadeira oposição de saberes e buscam nunca igualarse no saber da vida, mantendo-se como técnicas antes de mais nada ${ }^{6}$. Uma das

${ }^{6}$ Esta dificuldade que as mulheres profissionais têm de, ao mesmo tempo, identificarem-se com o grupo de usuárias e suas questões e defenderem pontos de vistas da instituição, no jogo das diferenças, acirra-se nas situações de grupo e na disposição de ações educativas do tipo dialógicas ou comunicacionais. Veja-se interessante estudo acerca desta mesma situação de conflito quando em atividade de educação em sala de espera, em Rodrigues et al.,1996. 
mulheres reclamava de uma gravidez indesejada, quando outra, buscando consolá-la, afirmava que "gravidez nunca vem na hora certa". Mas é a enfermagem que chama a possibilidade do poder feminino, por meio de seu poder de técnico: “ Acho que a palavra nunca é muito grande. Eu já vi. Eu trabalho num local que eu tenho contato com grávida, direto! Tem gravidez planejada...". Experiência feminina transmuta-se em poder... ganha maior valor de verdade e de ensinamento moral7.

Há, no entanto, uma sensação de batalha perdida. Mesmo as profissionais, apesar da veemência da fala, parecem perceber que a desconfiança com a efetividade dos métodos e o medo dos efeitos danosos à saúde têm base em uma experiência muito concreta, que está nas relações de gênero. A relação com os homens no mundo da vida e as condições estruturais vividas pelas mulheres esta, sim, problemática assumidamente compartilhada por todas as mulheres presentes na cena - passa muito longe da sala de grupos do Centro de Saúde e das informações técnicas, tal como colocado por uma usuária de escolaridade superior:

Eu, quando fiquei menstruada fui ao ginecologista, eu sei todo ciclo fisiológico e nem por isso deixei de ficar grávida. Não é uma questão cultural, é uma questão de tudo o que acontece, da falta de apoio da mulher. Sei toda parte glandular, parte hormonal, mesmo assim... Acho que as mulheres que não têm informação ficam se culpando o tempo todo de não ter a informação de tudo, fisiológica, anatômica, eu fui pro brejo (rindo). Porque não é assim, não é problema só delas. É um problema de todas as mulheres de todos os níveis. (Grupo de Contracepção)

A tentativa de tornar as mulheres mais autônomas encontra-se obstaculizada pelo simples fato de que a autonomia não pode ser concedida, nem depende apenas de um conjunto de informações. Se estas informações e este estímulo podem ser responsáveis por ganhos efetivos para as mulheres, também podem instaurar uma nova norma, quase impossível de ser atingida: a mulher independente, que controla a reprodução, tem prazer, conversa com o marido e

7 VICTORA (1995) estudando mulheres de classes populares em Porto Alegre, mostra que as idéias de gravidez prevista e desejada são muito diversas entre si, adquirindo cada uma sentidos distintos para mulheres e profissionais da saúde. 
tem os mesmos direitos do homem. A dificuldade das profissionais encontra-se na resistência de grande parte das usuárias ao modelo de identidade feminina e relações de gênero proposto pelo PAISM, que, muitas vezes, não é percebido pelas usuárias como desejado ou possível na vida prática. Ao mesmo tempo, há uma segunda dificuldade: como identificar-se com o feminino se a posição institucional proporciona uma relação assimétrica, em que o poder e o saber estão polarizados na profissional, que de um lugar não-identificado como igual ao feminino propõe um novo feminino? É possível do 'alto deste poder' conceder poder para as mulheres? Parece-nos que não se pode ordenar a alguém que seja livre ou outorgar-lhe poder... mesmo quando se pode instigar a emancipação pelo reconhecimento e discussão das condições de subordinação e violência.

\subsection{Mulheres falam dos homens}

Os homens foram objeto freqüente das falas nos grupos, em grande parte das vezes, negativas. Houve também algumas referências positivas, mas sempre ao 'meu homem', o parceiro atual. Quando falam dos homens em geral, usuárias e profissionais falam de um só personagem: "machista, ignorante, retrógrado, homem das cavernas". A reclamação é geral: "Homem é que nem tatu, não pode ver buraco", "homem é feito de pau". Usuárias e profissionais concordam: além de não se preocuparem com contracepção e não assumirem os filhos, os homens não se importam com a transmissão de DST/AIDS e querem determinar as ocasiões e formas de exercício da sexualidade.

Os dois grupos divergem, entretanto, nas estratégias para enfrentar esta situação. As profissionais propõem como solução de mudança o diálogo, a conversa entre o casal, conselho comum também nas consultas individuais observadas. O entendimento e respeito mútuo, buscados por intermédio da conversa, poderiam resolver os obstáculos que todas julgam encontrar nas relações 
com os homens no campo das escolhas reprodutivas e sexuais, mas apenas uma fração minoritária das usuárias parece concordar com esta proposta. A maioria delas não parece acreditar na possibilidade de um diálogo e, entre as mulheres usuárias, as posições se dividem mais uma vez. Uma parte delas não concorda que as coisas devam mudar. Querem o mesmo, de novo!

Assim, ao se tratar das possibilidades de exercício livre da sexualidade feminina e, a partir disto, definir positivamente o que é ser mulher nesta relação com os homens, o feminino é plural. Desta feita... também do lado das usuárias:

“... a gente já foi criada naquilo, já tem aquela experiência de velho, então, não tem como a gente mudar mais".

Ao que o serviço argumenta:

P- Você não vê perspectiva nenhuma? De mudança? Ou você não quer mudar, ou você acha que melhor ficar nessa, porque aí não vai se comprometer. O quê que você acha disso. Que é melhor ficar nessa ou...?" (Grupo de Contracepção).

Outra parte das usuárias não concorda com a atual falta de direitos das mulheres. Propõe como estratégia de mudança a ruptura de relações desfavoráveis sempre que possível. Para estas mulheres, o diálogo não parece uma solução viável e não condiz com sua experiência.

Concordar em matéria de homens e discordar das estratégias femininas também é o que ocorre quando o assunto é a maternidade (tratada pelos serviços como o número de filhos e o seu controle racional, com a divisão dos encargos contraceptivos). As profissionais concordam com as usuárias em relação à nãoparticipação masculina no que se refere à saúde reprodutiva. Todos os grupos de contracepção observados começaram com a proposta do serviço de discutir a necessidade dessa participação. Mas, como os homens não o freqüentam, este papel tem que ser feito pela mulher, que deve mudar 'seu homem'. Muitas mulheres, apesar de concordarem com a necessidade da participação masculina na regulação dos filhos, podem se sentir indefesas com este encargo adicional. Como 
aumentar o poder em uma relação marcada por desigualdades estruturais somente com a vontade individual ou a boa vontade do serviço? Algumas delas declararam preferir outra estratégia: já que os homens não querem "assumir", elas se recusam a aceitar que eles reconheçam a paternidade ou ajudem financeiramente, para não dar a eles "nenhum direito" sobre os filhos, e fazem questão de assumir toda a responsabilidade sobre as crianças.

Em relação à sexualidade, profissionais e usuárias concordam que a mulher tem direito ao prazer, e que o respeito é fundamental para este prazer. Concordam também com a idéia de que os homens, principalmente os maridos, não aceitam uma recusa quando querem sexo: "Homem quando ele quer, ele quer". Mas, enquanto o serviço chega a considerar "dar-se só para satisfazer a ele", literalmente, uma violência, algumas mulheres defendem que "servir a ele" pode ser necessário... para que ele não arranje outra.

O tema da 'outra' é crítico, revelando cisões e rearranjos entre casadas e solteiras (potenciais 'outras'), que se combinam diferentemente com as profissionais. O mais complexo é a atuação destas em fato flagrado relativo à difícil situação de 'sexo seguro'... Dois códigos encontraram-se em disputa. Um é o necessário uso da camisinha sempre que há troca de parceiros, ou quando seu parceiro faz trocas (há outras/outros). O outro é o código milenar da nãopublicidade da situação de trocas (chamadas de infidelidades), para além da aceitação desta situação apenas como algo masculino. Não se pode falar dessa possibilidade na negociação. Diante das dificuldades relatadas, as profissionais encontram-se em um impasse. Concordam e vivenciam as dificuldades de negociar o condom, mas têm o dever profissional de recomendar seu uso. Face ao impasse, a estratégia é relativizar a regra técnica mais geral, 'usar condom em todas as relações', revertendo-a na fórmula: 'usar camisinha em relações eventuais ou quando pular a cerca'. Como este 'pular a cerca' é fato que não pode ser reconhecido, a estratégia da relativização da norma técnica revela-se como 
'capitulação' - que pode ser perigosa em relação aos rumos de prevenção da epidemia entre mulheres casadas, já que estas vivem relações de poder de extrema desigualdade, sem poder lançar mão de diálogo e confiança de relações simétricas e com pouco espaço para expressar estas dificuldades no serviço que busca acolhêlas. Sem eficácia técnica, mas resolução aparentemente técnica com total amparo da moral vigente, a adaptação da regra corresponde essencialmente a uma atitude conformista e, às ocultas, reconhecedora do problema principal, que permanece 'não abordado': a infidelidade na relação com os homens. Daí a razão de que as dificuldades relatadas pelas mulheres - "com eles não tem diálogo" - quase não encontrarem espaço de expressão, sendo, de fato, evitadas.

O caso do tratamento das DST é um exemplo de como esta situação pode ser difícil para os serviços de saúde. No final de um grupo de resultado de Papanicolaou, (a paciente tem corrimento recorrente), o diálogo com a enfermagem é como segue:

"M: Isso aqui eu levo (exame)?

Prof: Não, isso fica. Você queria levar? (silêncio)

Você melhorou do corrimento ou continua?

M: Continua

Prof: Então, agora ele precisa tratar, só você não adianta, tá.

M: E pra segurar ele? Não adianta! (pausa)

Prof: Ah, ainda não marquei no seu cartãozinho.

M: Queria fazer uma consulta de... é que eu tô sentindo umas dores de cabeça sabe, não sei se é sinusite." (Grupo de retorno de Papanicolaou)

Este exemplo tem sérias conseqüências para a proposta técnico-política do PAISM. As profissionais limitam-se a fazer o apelo ao diálogo - obstaculizado no interior da própria instituição em relação às dificuldades encontradas para a negociação sexual e seus empecilhos. Acabam por não enfrentar os obstáculos às ações propostas, mudando de assunto e sendo impermeáveis à questão. 
A medicação indicada para o marido necessitava da abstinência de bebida alcoólica. No prontuário desta mulher, no atendimento inicial realizado na saúde mental, dez meses antes deste episódio, está escrito:

... conta que esses sintomas (falta de ar, calafrios, irritabilidade, formigamento nas mãos, vontade de sumir, agredir as pessoas, sair sem destino), iniciaram há 5 anos, período em que descobriu algumas coisas que seu marido fazia; neste período era agredida pelo marido, quando então resolveu separar. "ele não aceita a separação, tudo o que ele comprava ele colocava no nome dos outros para eu não ter direitos" . Juiz avaliou que ela tinha que ficar com tudo ... o marido não a deixava em paz, quase todo dia a visitava e ameaçava, até que resolveu largar tudo e vir para São Paulo.

Hoje vive com outro companheiro que bebe e a ofende. "Ele bebeu o dia todo e ainda traz duas cervejas para casa." Conta que quebrou as duas garrafas e saiu andando pela rua. "Eu fico nervosa só em estar falando sobre isso". (Saúde Mental)

Esta informação não foi levada em conta no atendimento e a própria mulher, diante do impasse de não ter como "segurar o marido" para tomar a medicação, desloca a queixa para um pedido de atendimento médico para dor de cabeça, que esta sim tem alguma possibilidade de escuta e acolhida no serviço. A dificuldade de abordar o alcoolismo do marido, sua história de violência e a vulnerabilidade à DST faz com que o corrimento continue e o trabalho não se efetive, apesar das orientações repetidas e enfaticamente realizadas, porque depende do cumprimento de orientações que não podem ser obedecidas, e esta dificuldade não pode ser discutida. A efetividade do trabalho realizado está comprometida por não poder enfrentar esta questão diretamente.

Por que não enfrentam esse problema principal? Essa parece ser a grande questão, em suas situações de 'duplo': as profissionais também precisam manter-se como sujeitos técnicos; querem apoiar as mulheres por meio dessa técnica e, por fim, compartilham, na maioria das vezes, os mesmo códigos e valores morais. São, pois, situações de conflito de deveres, em que não podem apelar a qualquer saber exterior àquele momento da vida - nem o técnico-científico - que não oferece 
resposta-, nem o prático. Impasse moral, cuja resolução torna-se ainda mais dramática nas difíceis situações de violência.

\subsection{Situações de violência: o trágico na condição de gênero}

"Foram muitas horas com dor... mas a dor é... nunca senti tanta dor na minha vida... No hospital me maltrataram lá embaixo, as enfermeiras: "Cala a boca, na hora de dar foi bom, não!" "Você tá com tanta dor que você vai responder o quê? Já tá doendo. Elas tratam a gente como se não fosse nada. Acho que se nessa hora elas dessem uma palavra de carinho, de amor, mas não... já amenizava. A culpa não é da gente... "(Observação de grupo de contracepção).

Buscamos na análise distinguir situações de violência em que o sujeito estivesse totalmente anulado e, ao mesmo tempo, reconhecer as resistências e exercícios de poder que formam esses contextos que propiciam o surgimento da violência. Como as atividades não foram planejadas para estimular ativamente o relato de violência, surpreendemo-nos com a freqüência de atividades com situações espontaneamente apresentadas (sete, em 16 grupos). As situações que foram consideradas violência, em seu sentido mais estrito, emergiram sob diversas formas. Em relação ao espaço doméstico, houve três relatos de violência física e sexual; em relação ao espaço público, foi relatado um estupro e três registros acerca de violência institucional. Estas situações foram identificadas ao se falar de homens e sexualidade (quatro grupos) e sobre episódios de uso de serviços de saúde, especialmente em relação ao parto (dois grupos). Um aspecto interessante foi a emergência, algumas vezes, de mais de um caso naqueles grupos em que havia uma situação de violência relatada. É como se um relato propiciasse outros, em 'bola de neve', o que condiz com a alta prevalência do problema.

As reclamações dos serviços de saúde são dirigidas principalmente aos maus tratos recebidos no atendimento ao parto (dois grupos). Muitos foram cometidos por profissionais mulheres. O terceiro relato deste tipo foi de abuso sexual: uma usuária contou que o médico disse que faria o toque vaginal sem luva. 
As profissionais do CSE solidarizaram-se com as usuárias e propuseram a resistência: reclamar é a fala recomendada.

Nestas relações instituição hospitalar versus usuárias, entretanto, parece não haver a menor possibilidade de negociação. Em uma cidade como São Paulo, buscar assistência médica hospitalar em caso de parto é quase compulsório, exceto para uma pequena parcela com acesso a opções de outro tipo. Compelidas a buscar assistência, as mulheres encontram uma brutalidade que, dizem, é melhor "suportar calada ao invés de gritar, reagir ou dar escândalo e correr o risco de represália". "E se eu reclamo e fazem um corte maior, de propósito, só pra infeccionar e eu morrer?"

Independentemente de sua ocorrência, a possibilidade desta imagem é eloqüente para demonstrar o estado das relações entre instituições de saúde e usuárias. Encurraladas em seu campo de opções, a resistência pode-lhes custar bem caro.

"Deus me defenda! Acho que se eu parisse de novo, um lugar que eu não ia era o hospital. Eles cortam, depois vêm com aquela agulha aplicar (ri). Uma vem com anestesia para aplicar eu digo: "O quê?! Você não vai aplicar injeção nenhuma aqui, não! Não mandei vocês me cortarem! eu tinha filho não era preciso isso!", "Ah, então fica abertona aí!". Eu digo: "Deixa! Não é meu?"E fui me embora. Ai me colocaram na cama assim toda aberta, não tinha colocado um ponto. Depois começou a hemorragia. Chegou lá a doutora, queria aplicar, eu digo: "Não!", "Então vai de sangue frio mesmo!", eu digo: "Tudo bem!" Aí me costuraram a sangue frio, mas eu não deixei me aplicar a anestesia." (grupo de recepção/saúde da mulher)

Chama a atenção a falta absurda de diálogo e acolhimento desta mulher que experimentava pela primeira vez rotinas hospitalares. Objetificada na interação, ela defende sua dignidade, recusando-se a aceitar a injeção que poderia livrar-lhe da dor da sutura inevitável.

Também notamos que a identidade de gênero e solidariedade, que aparece no contexto do PAISM, contrasta com a insensibilidade de gênero demonstrada pela doutora neste relato. Mesmo estando as profissionais solidárias às mulheres, as 
reclamações quanto aos serviços tenderam a aumentar quando estas retiravam-se por algum motivo da sala de grupo. É interessante notar que as profissionais do Centro de Saúde, apesar de acolherem estes relatos e solidarizarem-se com as usuárias, estimulando o diálogo e a reação, não têm solução técnica a propor. Como conseqüência, parecem ficar um pouco incomodadas com as críticas, acabando por sempre cortar a discussão e mudar de assunto, sem fazer a tradicional 'fala final', como fazem em todos os outros temas. Dizem apenas "é difícil nossa vida, não é?", e voltam ao tema discutido anteriormente.

Deve-se lembrar a importância desta forma de violência para o assunto tratado neste estudo. Um serviço violento com seus usuários não pode ser acolhedor ou responder questões do tipo da que tratamos aqui. Na verdade, esta forma de violência institucional bloqueia a possibilidade de troca de opiniões e experiências, obstaculiza o debate público, mina a comunicação e reforça a violência.

Já a violência física e sexual é acolhida por profissionais e usuárias, contando com a solidariedade de todas. As mulheres que relataram violência doméstica não se colocaram apenas como vítimas, afirmando-se como sujeitos interagindo em situações extremamente difíceis. Muitas delas não reconhecem a própria situação como violência, ressaltando sua posição ativa na situação:

"Não é que ele me batia, a gente se pegava (Grupo de saúde da mulher/recepção)".

"o meu foi tipo de um estupro, mas ele não era assim tão violento. Tá certo que depois ele me batia, porque eu ficava de cara fechada para mostrar que não estava satisfeita com aquilo" (Grupo de contracepção).

Em um grupo de contracepção, houve a possibilidade de solidariedade e da discussão das razões destas situações - "as mulheres ficam em relações violentas por medo", disseram neste grupo duas mulheres que haviam saído de relações violentas. A afirmação categórica do direito da mulher ao respeito e o seu imperativo para a possibilidade de ter prazer foram o tema da primeira metade da 
sessão, quando se discutiu sexualidade e violência. A outra metade foi tomada pela discussão dos métodos contraceptivos, tema principal da atividade. O tema da violência foi trazido pelas próprias usuárias. Desde o princípio, as mulheres presentes declararam estar no grupo para discutir o prazer, apesar da explicação da profissional sobre os objetivos do grupo: discutir os métodos de evitar filhos. A coordenadora do grupo abriu espaço para a discussão, acolhendo a demanda apresentada, após tentar por duas vezes voltar ao assunto da fecundação. Ao ser permeável à necessidade do grupo, esta auxiliar possibilitou a emergência de relatos de violência.

Uma das usuárias queixou-se de não sentir prazer e perguntou se isto poderia ser trauma. Outra usuária respondeu que sim, já que seu primeiro marido era violento e ela não tinha prazer sexual, enquanto o segundo marido é carinhoso e ela tem prazer na relação sexual com ele. Diante desta resposta, a usuária que havia feito a pergunta fez o seguinte relato:

"Eu tinha um trauma comigo. Quando eu era pequena, tinha nove anos, um cão lá do norte pegou eu, e carregou para o mato, só que como eu era pequena, ele não conseguiu nada. Aí como eu tava vendo que eu não tava agüentando aquela situação que ele queria, aí eu meti uma mordida no braço dele e saí. Até nas minhas pernas tem uma marca de unha de gato. Você sabe o que é unha de gato, né? É, eu saí correndo nos matos (começa a chorar)".

Diante do trágico, todas parecem se unir. O grupo fica tocado e as outras usuárias acolhem e tentam alternativas de resolução:

"E se ela passasse num psicólogo, acho que melhoraria a situação dela", "Sabe, eu passei num psicólogo na gravidez dela, porque eu não aceitava minha gravidez, eu sou separada. Eu não aceitava, eu passei na psicóloga, e inclusive me ajudou bastante, tanto ela quanto o médico foram excelentes pessoas comigo. Me ajudou bastante."

Outras mulheres se colocam, contam suas experiências de violência sexual conjugal e como superaram. A coordenadora do grupo concorda com o 'encaminhamento' proposto pelas usuárias:

"Então, depois a gente pode conversar um pouquinho mais sobre isso, elas deram uma sugestão, o que você acha disto? Seria legal? Uma ajuda de um 
profissional mais especializado, para te ajudar. Junto com você, te ajudar a superar um pouco disto. Você gostaria de ter prazer, um relacionamento sexual legal, porque isso te incomoda pelo que você nos mostrou aqui hoje."

Profissionais e usuárias foram unânimes no acolhimento e na sugestão de intervenção. Porém, este acolhimento não é necessariamente compromisso de resposta, já que elas dependem de um projeto de trabalho. Nem sempre, também, é necessária uma resposta institucional além do acolhimento e valorização do relato. Três mulheres falam de situações de violência neste grupo, todas elas passadas. Apenas a que conta a tentativa de estupro recebe uma resposta - o encaminhamento para a saúde mental. Isto porque o grupo parece ter achado que ela estava sofrendo muito e se beneficiaria de ajuda profissional especializada no sentido de elaboração subjetiva do problema. Entretanto, parece que o acolhimento do próprio grupo foi o suficiente ou a proposta de resposta não correspondeu às necessidades da mulher, já que ela acabou por não marcar o atendimento no setor de Saúde Mental, ficando de pensar no assunto.

Um outro grupo, em que emergiu um relato de violência física conjugal, teve um desenrolar diverso. Era um grupo de resultado de Papanicolaou, em que se fornece o resultado do exame e discute DST e AIDS. Uma das mulheres fica tonta no decorrer da atividade e é atendida pela profissional, que a coloca deitada até o final do grupo, mas não toma nenhuma outra atitude. As outras mulheres preocupam-se com ela, mas a auxiliar que conduz a atividade não toma outra medida, a não ser deitar a paciente. Ao final do grupo, depois de dispensar as outras usuárias, a profissional mede a pressão arterial da mulher que ficara deitada. Está normal, diz ela, como eu suspeitava. A partir daí, conversa com a usuária. Tendo descartado a doença no corpo, procura alterações na vida da usuária. Neste momento, ela conta que tem "mania de limpeza", que é "muito nervosa" e que o marido "bate nela". Ao ouvir isto, a profissional tenta encaminhála à Saúde Mental. A mulher resiste: já foi diversas vezes, não gostou, acha que não adianta conversar. Sem outra resolução para o caso, a profissional dedica-se a 
convencer a mulher a aceitar o encaminhamento para a saúde mental. Diz que ela pode estar prejudicando a filha, que precisa de ajuda e está se recusando a ser ajudada. Nesta tentativa de encaminhamento, ao tentar responder, ela bloqueia a escuta e encerra o diálogo. Parece que, não conseguindo responder de modo satisfatório à demanda da paciente, sua angústia por ter algo a oferecer acaba por impedir a continuidade do trabalho de acolhimento que vinha sendo feito, e até escutar melhor a demanda da mulher e sua compreensão da situação. $O$ acolhimento é compreendido aqui como a qualificação do problema como importante pelo profissional, que demonstra interesse pelo mesmo.

O encaminhamento para o setor de saúde mental, mesmo quando a mulher já foi e não gostou, ou recusa-se, é bastante comum, como se notará em nossa análise. $\mathrm{O}$ encaminhamento é a primeira alternativa do serviço sempre que detecta problemas que não são doença inscrita no corpo. Parece imperar a seguinte lógica: se a doença não está no corpo, só pode estar na cabeça. Esta lógica, que sustenta a idéia da somatização, parece ser a grande responsável por esta forma de trabalho, como veremos ao analisar a fala profissional e os prontuários.

Neste caso parece ter sido mais difícil a situação de abordagem individual, já que o grupo, que tinha ido embora, não ouviu e não pôde amparar solidariamente a mulher. Este amparo do grupo aparece como identidade de gênero: "eu também já passei por isso...e sai" - a identidade de seus pares, usuárias, facilita a ausência de resolução imediata por parte do serviço. Além disto, o acolhimento e a qualificação do problema podem ser uma resposta em si, como visto no caso anterior. Neste caso, a interação é o trabalho. A profissional parece ter percebido que não se tratava de nenhuma patologia grave e que provavelmente a demanda dizia respeito a algo que não era doença, e mesmo assim não facilitou a emergência no grupo, esperando para levantar a questão quando ficou só com a paciente. Talvez isto tenha ocorrido pelo medo da profissional de não saber lidar com o grupo e/ou com caso tão complexo ao mesmo tempo. 
Em termos gerais, as situações de violência, apesar de não terem muitas opções de resolução, parecem mobilizar bastante os grupos. Impressiona também o contraste destas situações com o restante da orientação técnica, que busca a autonomia sexual e reprodutiva das mulheres. É como se todas as explicações sobre o corpo e o discurso acerca da paternidade responsável e do direito da mulher ao prazer caíssem por terra, diante de uma realidade muito cruel, que desafia de forma muito concreta a possibilidade de implementação da proposta do serviço para as questões práticas do mundo da vida (conversa, respeito).

Ao mesmo tempo, a possibilidade da emergência, acolhimento e resposta destas situações é também uma mostra da possibilidade de relações de comunicação mais simétricas no interior dos serviços. Por isso mesmo, será a partir destas relações que, a nosso ver, deveremos re-trabalhar os programas assistenciais, explorando as distintas concepções acerca do feminino e de seus caminhos; os diferentes saberes em jogo; e as diversas estratégias de luta e acomodação no sentido de encontrar alternativas mais eficazes para o trabalho. Não se trata de negar a diversidade, mas de reconhecermos o movimento de cisãoreunificação de um feminino (e quiçá um masculino) em transformação, como o aqui retratado, para que as relações possam ser compreendidas e direcionadas para formas interativas de maiores possibilidades dialógicas. A comunicação livre, que só pode dar-se na separação da autoridade técnica em relação à moral, evitando que a primeira se transmute na segunda, continua sendo, em nosso ponto de vista, o modo de se evitar qualquer forma de violência. 


\section{Condições de emergência, acolhimento e}

\section{resposta: Os prontuários}

Analisamos todos os registros dos atendimentos realizados para cada mulher observada, desde 1990 ou data da matrícula no serviço, naqueles prontuários em que era posterior a 1990. Todos os registros de diagnósticos e condutas em consultas individuais e grupos e todas as anotações encontradas em qualquer parte do prontuário referentes ao que foi considerado violência, contexto de violência ou conflitos relativos aos direitos reprodutivos, (categorias empíricas que serão detalhadas adiante), foram registrados em formulário próprio. Além disso, foi contabilizado o número total de consultas para cada mulher por categoria de atendimento, como já relatado.

Devemos, a princípio, lembrar o sentido do registro no trabalho em saúde. Não sendo extensivo, o registro médico e de outros trabalhadores da saúde prioriza aqueles pontos que o profissional acha importante para lembrar do caso quando o vir novamente. Funcionando como uma memória auxiliar, os registros servem para ajudar o profissional a recordar-se da história do paciente, sintetizando seus aspectos mais importantes e singulares (SALA, 1999). Logo, nem toda a violência que emergiu e eventualmente foi acolhida e trabalhada estará necessariamente registrada em prontuário. Mas o seu registro significa que o dado foi considerado importante ou peculiar o suficiente para ser anotado como um lembrete, para que a história do caso pudesse ser lembrada na consulta seguinte, ou para que outros profissionais que porventura tivessem contato com a mesma usuária pudessem estar conscientes do fato.

Isto quer dizer que o relato da violência parece ter sido considerado, de alguma maneira, nestes casos, importante para o trabalho em saúde. Claro que esta importância pode também significar para alguns profissionais um lembrete de 
problemas que levem à desqualificação dos sintomas percebidos pela mulher, mas não nos pareceu ser este o sentido preponderante no trabalho do CSE observado. Os registros foram analisados quanto ao que significam como qualificação do trabalho realizado: algumas vezes os relatos foram registrados apenas na anamnese, o que denota a emergência do problema e alguma continência; outras vezes transformaram-se em diagnósticos com condutas associadas, indicando, assim, não apenas oportunidade de emergência, mas também uma determinada forma de qualificação e resposta merecedora de registro.

As anotações encontradas em prontuários foram divididas, como já exposto, em três categorias: violência física, contexto de violência e conflitos em torno de direitos sexuais e reprodutivos. Foram classificados como registros de violência fisica ou sexual aqueles em que havia as seguintes situações:

$\checkmark$ A mulher é agredida fisicamente

$\checkmark$ A mulher agride fisicamente os outros

$\checkmark$ Os animais ou objetos pessoais da mulher são atacados

$\checkmark$ A mulher é obrigada a ter relação sexual

Nestas situações, a relação está rompida. Não há possibilidade de interação, a comunicação está impedida e o campo de ação de um dos sujeitos, anulado. Foram encontrados 12 prontuários com algum registro deste tipo, em 15 consultas, porque alguns prontuários tinham registros em mais de uma consulta. Destas, cinco consultas foram realizados nos atendimentos na saúde mental, seis na atenção à saúde da mulher (três em atendimento de enfermagem para queixas ginecológicas e três em consultas pré-natal, sendo duas conduzidas por médico e uma por auxiliar de enfermagem), duas no pronto-atendimento da demanda espontânea e duas nas atividades grupais. 
O problema emergiu pela primeira vez em consultas na saúde mental em 4 das 12 mulheres observadas. Uma delas procurou o setor por demanda espontânea, mas as outras três foram encaminhadas pelo CSE ou outros serviços clínicos da região. A maioria absoluta das 12 mulheres (9) tiveram ao menos um encaminhamento para o setor de Saúde Mental. É interessante perceber que as três que nunca foram encaminhadas à Saúde Mental tiveram registrado o seu diagnóstico em prontuário, diretamente, como violência ("Violência social”, "trauma por agressão física", e "miséria social/violência doméstica"), enquanto várias daquelas encaminhadas para a Saúde Mental não ganharam este diagnóstico, mas sim outros, indicativos de sofrimento psicológico. Dois destes três casos apareceram em consultas médicas de pré-natal, e o terceiro, no pronto atendimento. $\mathrm{Na}$ consulta de pré-natal, os casos receberam como conduta a proposta de orientação (não apenas para violência, mas para questões como DST e registro dos filhos) ou continência. No pronto atendimento, a mulher foi encaminhada para a DDM.

Nas mulheres encaminhadas para a saúde mental, foram percebidas alterações depressivas ou problemas emocionais que justificam o encaminhamento. Esta referência é adequada tecnicamente e busca responder ao sofrimento que foi percebido pelos profissionais. Portanto, quando as situações de violência podem ser enunciadas, sua principal resposta será a Saúde Mental e será valorizado, na situação, o seu "sofrimento mental". As mulheres, por sua vez, expressam seus problemas como um todo, uma anormalidade sócio-vital que remetem aos serviços como potencial doença (de preferência, física, que tende a ser menos estigmatizada e mais valorizada).

O reconhecimento de seu problema como doença mental, como propõem os profissionais, pode, como vimos no relato das mulheres, criar estigmas importantes para elas nas relações familiares, "desempoderando-a" no círculo doméstico. Disto decorre o padrão mais comum de consumo de serviços destas 
pacientes: um uso intensivo do pronto atendimento ou atendimento de enfermagem por queixas vagas e, ao mesmo tempo, uma tentativa do serviço de encaminhá-las para a saúde mental, com maior ou menor sucesso. A história de violência, nestes casos, aparece como um dado na história, que torna ainda mais importante o encaminhamento, já que os psicólogos e psiquiatras são vistos como possuidores da técnica de lidar com os problemas percebidos: questões emocionais e privadas das pessoas. Portanto, o sentido do encaminhamento parece ser cuidar dos sintomas que são percebidos como sofrimento mental, mais do que especificamente responder à violência. Quando o trabalho adquire esta outra finalidade (responder propriamente à violência), recebe outro acolhimento e orienta-se para outros recursos. O apelo à saúde mental passa a ser, nestes casos, apenas uma das alternativas em um leque de respostas bem mais amplo, ainda que não necessariamente suficiente.

Por exemplo, uma mulher foi encaminhada à saúde mental por "atitude depressiva, violência e insatisfação no relacionamento", detectadas em um grupo. Não compareceu e, algum tempo depois, voltou ao atendimento de enfermagem com um hematoma no rosto e queixas de agressão física pelo marido. Desta feita, o fato foi registrado apenas como violência, e a conduta foi pedir um exame de HIV (solicitado pela paciente), e encaminhá-la para um serviço de referência para mulheres em situação de violência. Portanto, o serviço facilita parcialmente a emergência do problema, mas nem sempre consegue qualificá-lo como tal e fazer decorrer daí ações específicas. O encaminhamento para a saúde mental é uma ação bastante comum para estas mulheres, pois responde à queixa sem necessariamente qualificá-la como violência. A resposta se esgota no plano do sofrimento mental conexo e, muitas vezes, acaba por não ser satisfatória do ponto de vista da mulher e da eficácia técnica.

Vejamos a seguir alguns outros diagnósticos encontrados nos outros prontuários: 
Somatização, depressão, pânico, histeria

Auto-estima, depressão, violência, candidíase de repetição

Personalidade histriônica e vertigens

Depressão

Marido com tendência à violência

* Histeria conversiva

Depressão e ansiedade

Dificuldade com o marido e problemas emocionais

Note-se que os registros de violência física e sexual foram relativamente freqüentes $(8,45 \%$ dos prontuários examinados), se comparados com a fala profissional sobre a ausência do tema no serviço. Seu aparecimento, ainda que mostre a existência de canais de comunicação no serviço, que propiciam sua emergência, não significa necessariamente que a violência seja considerada como problema a ser trabalhado, já que, muitas vezes, ele não aparece como tal no diagnóstico. O que nos pareceu mais freqüente é uma seqüência de queixas dirigidas ao serviço, em que a violência aparece em um contexto de "vida ruim" que leva os profissionais a compreenderem o problema (que pode emergir explicitamente ou não), como não biológico, mas sim psíquico, e responder com o encaminhamento para a saúde mental, "psiquiatrizando 8 " ou psicologizando este sofrimento.

Foi bastante interessante perceber que, aparentemente, quando o problema é percebido como uma situação de violência explícita, e diagnosticado como tal, a

8 Para SENNA(1999), a psquiatrização da medicina incorpora ao psíquico a lógica causal própria da prática biomédica. 
conduta é mais variada, e pode ser: acolhimento, continência, orientação quanto à DST, registro dos filhos, matrícula dos filhos na escola e encaminhamento para serviços específicos (DDM, Centros de referência, Saúde Mental). Nestes casos o encaminhamento para o setor de Saúde Mental tem outro lugar na resposta adotada, pois o problema foi recortado de outra maneira. Em vez da clássica díade "o problema ou está no corpo ou na cabeça da mulher", a questão passa a estar em uma situação relacional e social que pede medidas intersetoriais. A discussão destas alternativas com a mulher só é possível quando o problema é recortado e qualificado deste ponto de vista - violência e seu contexto e desdobramentos, e quando se estabelece uma interação capaz de permitir esta discussão sobre as características do problema, sua definição e as propostas de solução.

Os registros considerados como contexto de violência foram aqueles que não traziam relatos específicos de violência física ou sexual, mas sim referência a situações de conflito que denotam um contexto de presença ou possibilidade de emergência de violência, por desrespeito e falta de interação comunicativa:

$\checkmark$ Restrição de contatos com amigos e parentes

$\checkmark$ Violência entre pessoas do núcleo doméstico, parentes e amigos

$\checkmark$ Desqualificar, xingar, descontar, brigar, ameaçar

$\checkmark$ Restrição para sair de casa

$\checkmark$ Recusa em prover a casa

Tentativa de suicídio

Marido não deixa trabalhar ou estudar

Foram encontrados 13 prontuários com este tipo de registro. A violência física e o contexto de violência apareceram algumas vezes em um mesmo 
prontuário, e parecem dizer respeito a uma situação em que freqüentemente coexistem: cinco dos 12 prontuários com algum registro de violência física ou sexual tinham também referência a situações deste segundo tipo. Além destes, encontramos mais oito prontuários com algum registro desta categoria, sem menção direta a violência física envolvendo a usuária. Muitos prontuários tinham também mais de um registro na mesma categoria, como se pode ver no anexo 5.

Parece-nos que falar das humilhações, insultos e brigas é uma forma de falar de situações conflituosas no ambiente doméstico, que tem relação com o problema de saúde que vem sendo tratado. Reunimos aqui o que tem sido considerado como violência emocional ou psicológica e também a violência física entre outros membros da família. São registros que denotam situações familiares com pouca interação comunicativa e possibilidade de ação conjunta solidária. Foram encontradas 16 consultas com registros deste tipo. Aqui, também, os registros concentraram-se em dois tipos de atendimento: a consulta inicial da saúde mental (dinâmica familiar) - oito consultas- e o atendimento pré-natal e queixas de saúde da mulher (médico e de enfermagem) - sete consultas, além de uma atividade em grupo.

Dos oito prontuários que têm apenas este tipo de registro (não há também referência a violência física e sexual), três deles expressaram-se, pela primeira vez, em consulta de saúde mental, e quatro mulheres foram encaminhadas e compareceram a pelo menos uma consulta. Repete-se aqui, portanto, o padrão de remeter estes conflitos para o setor de saúde mental, com menor insistência do que em relação à violência física, mas com freqüência ainda bem maior do que com as usuárias em geral. Repete-se também um padrão de emergência que mostra a saúde da mulher (especialmente o pré-natal e o atendimento de enfermagem) e a saúde mental como os grandes canais de escuta e registro do problema no serviço. 
A questão é que, ao recortar o problema desta maneira, a violência fica subsumida em uma inadequação individual de cada mulher, aparecendo apenas como potencial "doença mental" e não como problema relacional e social. Como vimos, se para algumas mulheres este encaminhamento pode ajudar, ainda que parcialmente, para outras este encaminhamento pode ser visto como um atestado de que é louca mesmo, como a família apregoa, e contribuir para diminuir seu poder nas relações domésticas ou, simplesmente, não atender a suas necessidades e descontinuar o atendimento.

Já os registros considerados como relativos aos direitos reprodutivos foram:

$\checkmark$ Paternidade/maternidade (conflitos em termos de assumir o filho)

$\checkmark$ DST/infidelidade

$\checkmark$ Ter ou não ter filhos

$\checkmark$ Aborto

$\checkmark$ Transar ou não transar

Este tipo de registro refere-se a conflitos na esfera da saúde reprodutiva que dizem respeito a relações de poder desiguais, diferenciando-se da violência, que busca anular completamente a relação e a possibilidade de resistência do outro. Aqui, a relação existe e os dois sujeitos são reconhecidos, ainda que esta interação aconteça em um contexto de relações de gênero desigual, em que os direitos reprodutivos não são garantidos e as mulheres arcam com a maior carga. Mas estes registros dizem respeito a estratégias de controle e de retomada de comunicação "livre" na negociação prática dos direitos reprodutivos entre homens e mulheres, que repercutem e se valem das ações em saúde.

Estes foram os registros mais comuns e apareceram concentrados nas atividades de atenção à saúde reprodutiva. De 28 consultas com registro deste tipo, 
contabilizando 23 mulheres, 21 dos relatos apareceram em atendimentos de atenção à saúde da mulher (13 em pré-natal e oito em atendimentos de enfermagem/saúde da mulher), um em consulta de ginecologia, três em atendimentos em grupo, dois em pronto-atendimento e apenas um em consulta de saúde mental.

Muitas destas mulheres também tinham algum registro de violência e contexto de violência. Note-se que parece haver uma diferença importante entre aquelas mulheres com registro também de violência ou contexto daquelas com registros apenas de conflitos na esfera de saúde reprodutiva (15 das 23 mulheres com algum registro acerca de direitos reprodutivos e sexuais). Este tipo de problema, ligado imediatamente às ações de saúde reprodutiva, não parece suscitar encaminhamentos para o setor de saúde mental, ainda que sérios conflitos sejam explicitados. Apenas uma destas usuárias foi encaminhada para este setor.

Esta diferença confirma a distinção que achamos importante entre as situações de violência e de conflitos em torno dos direitos reprodutivos. Os profissionais podem acolher as questões de direitos reprodutivos e sexuais, porque há uma proposta tecnológica de trabalho para algumas situações deste tipo. Estes relatos não se transformam em diagnósticos nem têm ações profissionais específicas registradas em prontuário, mas fazem parte da interação necessária para o diálogo em torno de problemas e opções de respostas apresentadas em termos do apoio social necessário à garantia destes direitos. A desigualdade de poder existente nas relações de gênero indica questões para o trabalho, como por exemplo, quando a usuária declara que nem sua família nem o pai da criança desejam a gravidez, ou quando diz que o seu companheiro não aceita o uso de camisinha ou o tratamento prescrito para uma doença sexualmente transmissível. Estas questões podem estar suprimidas da "conversa" em saúde ou podem estar compondo o trabalho e serem manejados de formas distintas, a depender da qualidade de interação presente. O registro regular destas questões e o não 
encaminhamento para outros setores parecem indicar que estas são informações que são levadas em conta no próprio trabalho de garantir, por exemplo, a liberdade possível nas escolhas reprodutivas das usuárias.

Vários prontuários tiveram mais de um tipo de registro em mais de um tipo de atividade, mostrando situações complexas e uma inter-relação entre estas três categorias, como é possível observar no mapa onde todos os prontuários que tiveram algum registro são apresentados (anexo 5).

Nem sempre, entretanto, um determinado registro é considerado em novos atendimentos. A usuária que morreu, por exemplo, tinha um registro isolado de violência em um pronto-atendimento (agressão pelo amante) e inúmeros registros de queixas clínicas as mais variadas, em bastante intensidade, utilizando 5,9 consultas/ano no serviço, quase todas de pronto atendimento e em segundo lugar atendimento de enfermagem. Ela morreu com menos de 40 anos. Segundo informação de sua irmã registrada em prontuário, a morte foi conseqüência do alcoolismo, que nunca foi visibilizado no serviço como problema (e está associado com situações de violência em diversos estudos). A leitura de seu prontuário mostra como a invisibilidade do alcoolismo e o aparecimento apenas pontual da situação de violência empobreceram o cuidado à sua saúde que seria potencialmente desejado do serviço, ainda que ela tenha sido sempre atendida em grande freqüência e até encaminhada à saúde mental.

A preponderância do registro em alguns tipos de atendimento, que se mostraram canais de comunicação mais eficazes, deu-se, a nosso ver, por diversas razões. Em relação ao atendimento na saúde mental, pensamos que a modalidade de atenção realizada na dinâmica familiar (uma entrevista aberta, com fluxo narrativo livre) foi a grande incentivadora dos registros de violência física e contexto de violência neste espaço. O registro de violência ou contexto aconteceu, no entanto, restritamente ao espaço da dinâmica familiar. A violência registrada 
não é apreendida como objeto de trabalho, e não aparece mais na seqüência de atendimentos, que aliás, tem um registro extremamente sucinto, limitando-se a um breve parágrafo com as condições da paciente e medicação utilizada, se for o caso.

Quando comparado o registro com a quantidade de consultas realizadas, a dinâmica familiar mostra toda a sua importância em termos de facilitação da emergência e registro do problema: as 142 mulheres investigadas compareceram a 43 dinâmicas familiares e primeiras consultas ao setor, e em 14 delas havia ao menos um registro de violência, contexto ou conflito em torno dos direitos reprodutivos, o que significa que $32,5 \%$ das consultas realizadas tinham este tipo de registro. É interessante lembrar que, dos 20 prontuários com ao menos um registro de violência ou contexto, 13 passaram ao menos uma vez por esta atividade. A grande maioria foi encaminhada do setor de clínica de adultos por queixas do tipo ansiedade, depressão, queixas sem confirmação clínica ou conflitos familiares. Outra parte veio encaminhada de outros serviços e uma minoria por demanda espontânea. Entretanto, a violência não é tematizada como problema no seguimento realizado, que é concebido e respondido restritamente como sofrimento psicológico. Note-se que se percebemos esta restrição também achamos bastante importante que o problema possa ser reconhecido pelos profissionais, em geral, e que encontre canais de expressão, e nos parece que a possibilidade de encaminhamento para a saúde mental é facilitadora neste sentido.

Enquanto estes atendimentos foram bastante pródigos no registro de violência ou contexto, eles quase não propiciaram o registro dos conflitos na esfera dos direitos reprodutivos, que se concentraram nos atendimentos de pré-natal e queixas ginecológicas, estas últimas especialmente quando o profissional era uma auxiliar de enfermagem.

As consultas de pré-natal, médicas ou de enfermagem, mostraram um padrão semelhante quanto aos registros encontrados. Parece que o pré-natal, por 
padronizar perguntas sobre o companheiro e relações familiares, foi mais permeável aos relatos. Imaginamos que isto se dá porque no pré-natal a pergunta de violência vem acoplada à situação de vida atual, aceitação/rejeição da gestação, tentativa de interrupção, etc. Na ficha que deve ser preenchida existe a menção explícita à violência, e este fato também deve ter propiciado esta emergência. Mas na consulta ginecológica também há esta menção explícita e não percebemos o mesmo resultado, já que não temos registros de violência nestes atendimentos, e mesmo os conflitos nos direitos reprodutivos só foram encontrados em uma consulta deste tipo. Já as queixas ginecológicas trabalhadas pelas auxiliares de enfermagem também propiciaram a emergência de violência, contexto e direitos reprodutivos.

Deve-se lembrar que os médicos que realizam o pré-natal são sanitaristas pesquisadores e docentes do serviço, o que facilita a introjeção do modelo de trabalho proposto e sua operacionalização, enquanto o profissional ginecologista realiza sua ação profissional de forma mais clássica e incorporou menos o modelo de trabalho idealizado. As diferenças de desempenho encontradas entre os profissionais expressam, nos diferentes desempenhos, diferentes formas de exteriorizar a introjeção do modelo a partir de uma experiência prática particular.

As consultas de assistência à saúde da mulher foram especialmente propícias para o registro de conflitos na esfera dos direitos reprodutivos, que correspondem à maioria dos registros encontrados. Assim, em 455 consultas médicas de pré-natal foram encontrados 21 registros (4,6\%), 13 deles relativos a direitos reprodutivos (2,8\% do total) e oito, a contexto ou violência. Este tipo de registro é coerente com a atividade desenvolvida, que trabalha com a saúde reprodutiva da perspectiva da emancipação das usuárias. No atendimento de enfermagem de queixas ginecológicas, encontramos um porcentual semelhante de registro $(3,82 \%$ dos prontuários com algum registro, 1,5\% com algum relato de contexto ou violência). 
Paradoxalmente, os grupos tiveram um registro relativamente baixo destas situações $(2,46 \% \%)$. O pronto-atendimento foi ainda mais baixo $(0,87 \%)$, indicando uma menor permeabilidade para este tipo de problema e, provavelmente, um espaço de interação bem mais restrito.

A altíssima porcentagem de registros em dinâmica familiar da saúde mental chama atenção. Devemos considerar, entretanto, que os casos de violência encontrados em pronto-atendimento, por exemplo, foram duas vezes explicitamente registrados como diagnóstico e a situação de violência trabalhada por meio de encaminhamentos próprios, enquanto a emergência massiva na saúde mental não significou o reconhecimento do problema como objeto a ser especificamente trabalhado pelo serviço, mas sim um achado no relato da mulher sobre sua vida, que serve como contexto de diagnósticos como depressão e ansiedade, recortando (e, portanto, respondendo) apenas desta forma o problema, promovendo o que poderíamos chamar uma "psiquiatrização/psicologização" (em analogia com medicalização).

Já os grupos, especialmente propícios à emergência do tema em nossa observação, colaboram com um número relativamente pequeno de registros. Achamos que isto se dá pela função do registro neste trabalho. O registro do grupo é sumário, indicando basicamente o comparecimento da mulher à atividade e seu envolvimento em termos de participação. Por isto, pensamos que, apesar de um local privilegiado para emergência dos temas procurados, os grupos não têm o registro correspondente. Isto quer dizer que, embora seja um bom canal de comunicação e ocorra alguma escuta, esta não implica necessariamente qualificação, por falta de uma resposta antevista ao problema assim colocado.

Mais importante é considerar os prontuários por inteiro. $\mathrm{O}$ padrão mais comum, como já dito, é o de mulheres que usam a saúde do adulto por queixas diversas, têm relatos de violência ou contexto, conflitos na esfera dos direitos 
reprodutivos ou queixas de ansiedade e/ou depressão, e são encaminhadas pela saúde do adulto ou por hospitais da região aos quais recorreram, ao atendimento da saúde mental. Lá, na dinâmica familiar, a violência é pela primeira vez ou novamente escutada, mas não se transforma em objeto de trabalho como tal para os profissionais, dissolvendo-se entre outros elementos da vida prática.

Vejamos agora o registro de um prontuário que mostra um padrão de registros como o exposto acima, quando a violência é tomada exclusivamente como sofrimento mental:

\section{Maria das Dores}

02\7\90 puerpério tardio:

Dificuldade de relacionamento com o bebê e o marido. Marido não colabora, depois do nascimento do filho, a vida está muito ruim.

Em 17\11191 Pronto Atendimento (PA)

Dores pelo corpo todo e na cabeça, com dor na boca do estômago. Refere dores nas pernas. Destrói tudo em casa qualquer coisa a descompensa. O marido bate nela.

Diagnóstico e conduta:

Somatização - medicação +Saúde Mental

Síndrome dispéptica e tontura - Sintomáticos

\section{Em 05\2\92 PA}

Aborto provocado por medicamento. Estava com dores e sentia muita insegurança porque o marido tinha outra mulher.

Faz mais 4 vindas ao PA. Na última, conta que há nove meses toma medicação abortiva para descer a menstruação. Convencida a pôr o DIU. Vem ao $\mathrm{CN}$, mas falta ao retorno e não coloca. É encaminhada novamente à SM e falta.

\section{6/02/95 PA :}

Há três semanas teve episódios de desmaio, não tendo sido encontradas causas orgânicas/funcionais pelos médicos do PS. Refere ser muito nervosa e já ter tido episódios semelhantes. Queixa-se de cefaléia intensa, inespecífica, sem fatores desencadeantes, que responde a analgésicos comuns.

Diagnósticos e conduta:

Ansiedade - Enc. à Saúde mental 
Resistência SM - Em ocasião anterior foi encaminhada e faltou. Reconversada relação entre sintomas ansiedade e SM

Papanicolaou - marcar

Não vai à SM e continua a usar o PA por cefaléia, dispepsia, ansiedade.

Em 17/02/98 é encaminhada ao grupo intermediário e de lá para a saúde mental de novo.

0515198 grupo intermediário.
Refere brigas violentas com marido.
17\3198 SM (Dinâmica Familiar.)
Grupo diagnóstico: Há mais de três anos, nervoso que não
consigo controlar. Chega até a desmaiar, não vejo nada: fica uma hora
desmaiada. Ansiedade, respiração forte, mão gelada, tem vontade de
sair, desânimo, faz tudo com raiva, só vem piorando. Insônia terminal.
Expectativas: se não tiver um remédio, não sei aonde vai parar
isto. Já foi encaminhada por causa do desânimo mas nunca se tratou
direito.
Síntese da compreensão do GD: Depressão, pânico, histeria
Refere muito nervoso. perde o emprego. As pessoas não
suportam seu nervosismo (pede remédio para o nervoso, só conversa
não adianta mais). Relata brigas violentas "eu rasgava as camisas dele,
quebrava as coisas, ele me batia". Teve infância feliz, o seu nervoso
começou depois que veio a SP e conheceu o companheiro. Marido não
bate mais porque deu queixa na polícia. O nervoso “é como um monstro
que dá facadas por dentro “... Não espero nada do futuro, acha que não
existe futuro nenhum. (Está com acompanhamento psiquiátrico - toma
medicação)
Entra em acompanhamento psiquiátrico. até hoje.
Quando passa no PA: diagnósticos de pânico ou depressão
grave, remetida ao acompanhamento na mental

Este caso ilustra aquilo que vimos tentando demonstrar. Durante um longo período de tempo, esta mulher fez uso do serviço com queixas diversas, tendo comparecido 13 vezes ao pronto-atendimento em sete anos. A conduta do serviço foi basicamente reconhecer a queixa e encaminhá-la para a saúde mental, encaminhamento ao qual ela resistiu bastante. Em suas palavras, precisa de remédio, conversa só não adianta. Por fim, é medicada, recebe diagnósticos que definem a sua situação e adere ao tratamento na saúde mental. Os profissionais 
insistem com ela acerca da relação entre seus sintomas, ansiedade e atendimento na saúde mental, mas a violência deixa de ser tematizada, apesar de ter emergido.

Vejamos agora um caso em que o problema da violência foi trabalhado mais diretamente:

2012195 seguimento o pré-natal
Fala de suas preocupações com o parceiro (traficante) que não
a faz feliz e, às vezes, ameaça com violência ... está numa “ sinuca "...
Diagnóstico: violência social
Condutas: continência (dificuldade de tomar medidas legais)
06l3195 seguimento pré-natal
Situação difícil: companheiro vivendo com outra.(usuária de
crack) e, por raiva, disse que não vai mais ajudá-la... Impasse! Acha que
ele ainda volta e vai tentar contornar na "lábia" a situação, para não
piorar mais ainda. Quando tiver trabalho outra vez a coisa muda.......
Diagnóstico: violência social
Condutas: continência aos seus problemas e aconselhamento
1014l95 seguimento pré-natal
Ouviu falar que o marido está com sífilis . De novo, muita
preocupação com doenças sexuais. Marido ainda não voltou ao lar, mas
preocupa-se... rediscutimos prevenção.
Diagnóstico: violência social
Condutas: situação estacionada. Orientada exaustivamente para
prevenção de DST.
Não veio mais ao PN, puerpério OK, orientada condom e
agendado DIU, faltou.

Vejamos o relato desta mesma mulher, algum tempo depois, em uma sessão do grupo de contracepção no serviço. Ela já saiu da relação violenta, está casada de novo e argumenta com outra mulher, porque lhe parece que o prazer, para ela, está associado ao respeito, e a frigidez, ligada ao "trauma":

- Eu achava que, eu penso comigo, né, não sei se todo mundo pensa como eu. Mas eu acho que ficar transando por trás, pondo na boca, não convém este tipo de relação. Ele queria assim, e quando ele vinha pro meu lado eu chorava, entendeu. Pai dessa menina. Agora esse não, me respeita na cama, por isso eu sinto, eu sinto, eu gosto, por mim eu transava com ele toda hora, ele me respeita na cama. 
Agora o pai dessa aqui, já não me respeitava, acho que ele me via como uma qualquer, tá entendendo. Agora esse que eu tô não, esse que eu tô me sinto muito bem com ele.

\section{(...)}

Bom,..., dizem os médicos mesmo falam a relação faz bem para a pessoa. Uma relação bem feita, agora uma forçada!

Porque o meu marido, não gostava porque era grosso, não foi o tipo assim dele, forçar, entendeu. Certo, ele até me batia. Eu não...

E- Essa coisa de apanhar também é violência.

É violência, ele ficava assim ele tentava aí eu tinha, aí eu ficava de cara feia, eu mostrava que não estava de cara satisfeita com ele.

E- Mas tinha relação?

Tinha, entendeu, eu tinha mesmo naquela brutalidade, eu tinha. Pra evitar briga, tá entendendo, pra evitar. Eu tinh, a mas depois, eu não tava satisfeita com aquilo, eu não gostei, eu ficava de cara feia, aí vinha as brigas porque ele achava que eu tinha que ficar satisfeita com aquilo.

(silêncio)

\section{(...)}

- Eu pensava, se eu ir trabalhar e largar essa menina na mão de outros, novinha prá judiar dela, então eu agüentava tudo o que ele fazia comigo. Eu fiquei durante quatro anos, eu falei quando a menina aprender a andar e falar eu caio fora. Aí eu perdi o medo, quando ela aprendeu a andar e falar eu já perdi o medo, porque se acontecesse alguma coisa com ela, ela me falaria. Eu tava presa, tava com medo de largar ela na mão dos outros, então eu passava toda aquela situação.

A superação da situação de violência deu-se aqui por um movimento planejado da mulher. Os profissionais do serviço parecen ter tido um papel legitimador e solidário, ao apoiar, aconselhar e acolher seu relato da situação de violência. Note-se que a auxiliar de enfermagem também sugeriu o "nome" violência para a mulher, que aceita o "rótulo", incontinente. Portanto, neste caso, o serviço, ao realizar a proposta assistencial, facilita a emergência da violência e busca formas inovadoras de acolhimento e resposta, favorecendo o debate e a reflexão sobre suas experiências. A resposta não tem aqui um caráter "resolutivo" em termos de uma solução proposta pelos profissionais, mas é muito mais o 
respeito e a consideração pela situação vivida, e a ampliação das possibilidades de reflexão sobre ela e seus desdobramentos.

Quando esta "resposta" mais direta e específica não é possível, ao menos existem canais de expressão, e o problema é acolhido mais restritamente como sofrimento mental. Note-se que quando consideramos aqui restrito o atendimento do tipo "saúde mental", é apenas no sentido de que partimos do princípio de que o problema é multifacetado e deve receber atenção em diversos setores da sociedade. Assim, obviamente o sofrimento mental é uma das faces das situações de violência, e deverá ser acolhido e respondido. Mas fazê-lo somente por esta faceta pode ocultar as dimensões jurídicas, de assistência social, trabalho, alcoolismo, educação e muitos outros que podem estar envolvidos na resposta que pode vir a ser pretendida pela mulher a partir do diálogo com o serviço. Além disto, como vimos, algumas mulheres não aderem ou não aceitam esta percepção do seu problema, recusando a proposta de atendimento na saúde mental por resistência e, portanto, não encontrando resposta. O essencial, em nossa visão, é a possibilidade de interação entre profissional e usuárias, que permita a discussão livre das possibilidades de delimitação, qualificação, continência e resposta (ainda que não necessariamente resolução do) ao problema.

Vejamos agora sinteticamente os resultados encontrados:

\begin{tabular}{|c|}
\hline PRONTUÁRIOS \\
Violência ou contexto ou Direitos reprodutivos \\
35 prontuários $-24,6 \%$ \\
Pelo menos violência ou contexto: \\
20 prontuários $14,1 \%$ \\
Apenas direitos reprodutivos: \\
15 prontuários - $10,6 \%$ \\
\hline
\end{tabular}




\section{Violência e saúde: os depoimentos de profissionais e usuárias}

As entrevistas realizadas com usuárias e profissionais permitiram que nos aproximássemos de suas concepções acerca da relação entre a violência e os problemas de saúde, e dos limites, articulações e possibilidades percebidos para a emergência, acolhimento e resposta destes problemas nos serviços de saúde. Estas concepções oferecem um novo ângulo de visão sobre o trabalho efetivamente observado nos serviços, agora do ponto de vista das representações dos agentes acerca de suas ações, agregando sentidos à análise do processo aqui estudado. Foram utilizados como material os depoimentos orais de profissionais e usuárias à pesquisadora.

A primeira constatação é que tanto usuárias como profissionais, com diferenças que serão apontadas a seguir, concordam que a "vida ruim e injusta" tem uma profunda conexão com os problemas que afetam a saúde. A natureza desta conexão não fica tão clara nem é tão consensual. A própria idéia de "conexão" não é apropriada para o que se considera este elo, especialmente para as mulheres entrevistadas. Para que se pense em conexão é necessário que a situação ruim de vida, a violência como um de seus componentes e a situação de saúde sejam tratados de forma separada. Se estas divisões analíticas podem ser bastante importantes e até úteis para a prática profissional e também para a pesquisa, para as mulheres podem parecer artificiais, já que na vida prática "existimos nosso corpo no mundo" e a saúde é, portanto, a própria existência em uma determinada situação de vida.

Também é importante lembrar que o que venha a ser "violência" não é homogêneo entre os entrevistados. Para os profissionais, as lesões físicas advindas diretamente da violência também são lembradas ao se falar nesta conexão, mas é 
principalmente o sofrimento que é apontado como situação que impede a saúde. Já para as mulheres, o conceito de violência pode ser bem mais estreito, e duas delas não se reconheceram como tendo sofrido violência, apesar de terem sido selecionadas por nós para entrevista, porque se encaixaram em nossos critérios de violência física ou sexual. Também o que venha a ser "problema de saúde", ou mais restritamente "doença", não é consensual entre usuárias e profissionais, como visto até aqui.

Mas todos e todas concordam com o senso comum de que uma vida ruim e injusta leva ou é a própria falta de saúde. Genericamente, pudemos constatar que a idéia de sofrimento ${ }^{9}$ parece ser importante nesta mediação percebida entre saúde e violência. A partir daí, surgem diversas posições sobre o papel da assistência à saúde sobre o problema-violência, o sofrimento a ele conexo e as queixas referidas aos serviços de saúde, que serão detalhadas a seguir.

Já vimos que a possibilidade de emergência destes problemas no serviço é dada principalmente pela estrutura assistencial montada, operada pelos profissionais em interação com as usuárias. Depois de termos observado o trabalho em operação e analisado os seus registros, vamos ouvir agora os depoimentos dos nossos personagens acerca do tema em estudo.

Apresentaremos, a princípio, nossa interpretação das entrevistas com os profissionais e depois com as mulheres usuárias, buscando com isto compreender melhor o diálogo e as ações destes personagens observados no interior dos serviços de saúde.

${ }^{9}$ A idéia de sofrimento é também tematizada por SENNA, 1999, como bastante importante para o trabalho em saúde, especialmente com os "pacientes difíceis". 


\subsection{Os profissionais de saúde}

O contexto da entrevista realizada merece ser destacado aqui. Os médicos e auxiliares entrevistados foram convidados a responder sobre a conexão entre violência e saúde, quando ainda não havia trabalho organizado sobre o tema no serviço, mas existia a expectativa de sua implantação em breve, da qual todos estavam conscientes. A entrevista foi utilizada, assim, para que os profissionais expressassem suas idéias sobre qual deveria ser (ou não) a ação do serviço sobre este problema, participando, desta maneira, da reflexão e da construção de uma ação institucional organizada que vinha sendo gestada e foi mais recentemente operacionalizada. Parece-nos que este contexto da entrevista favoreceu o posicionamento profissional, já que o problema colocado é próximo e pertinente ao trabalho e já vinha, de forma mais ou menos direta, sendo discutido. As respostas foram manifestações sobre um assunto que vem sendo debatido e sobre o qual há polêmicas. A maior delas recai sobre o quanto pode ser resolutivo abrir espaço, no atendimento, para o acolhimento de questões que escapem da lógica biomédica, e que não têm alternativas assistenciais reconhecidas que tenham tido sua eficácia e efetividade comprovadas e, portanto, o quanto tal problema pode ser considerado um objeto legítimo de ação profissional.

Sabemos que os profissionais de saúde levantam ativamente inúmeros problemas na vida cotidiana dos usuários dos quais eles não têm "consciência", a começar pela hipertensão arterial sistêmica e todas as recomendações de hábitos dietéticos e exercícios que são necessários para seu controle. A violência também parece ser, como a hipertensão, risco para diversas patologias. No entanto, para a hipertensão, há um suporte em termos de evidências científicas e alternativas terapêuticas que justificam a correção técnica desta "intromissão" na vida privada. Esta aparente diferença de eficácia e, portanto, de legitimidade técnica merece ser examinada com cuidado. 
Em primeiro lugar, a eficácia da intervenção dos serviços de saúde sobre a mortalidade decorrente de doenças cardiovasculares, por meio do controle de fatores de risco na consulta médica individual (estratégia de risco), é bastante parcial e limitada, tendo vantagens, mas também sérias desvantagens em relação a medidas de mudança de hábitos populacionais (estratégia populacional), como transformações na indústria de alimentos quanto ao conteúdo de sódio ou à publicidade de sua presença nos alimentos industrializados, por exemplo (ROSE, 1988). Em segundo lugar, a eficácia de intervenções nos serviços de saúde identificando, acolhendo e respondendo ao problema da violência contra a mulher ainda não é conhecida, porque existem poucos estudos de programas implantados e avaliados. Nos estudos existentes sobre os profissionais, como vimos, a aderência às recomendações de busca ativa sistemática é bastante pequena. Também não temos dados sobre o impacto do movimento de mulheres e das Delegacias de Defesa da Mulher sobre as relações interpessoais e o problema da violência no Brasil, para além da constatação do aumento das denúncias deste tipo de crime que as DDMs propiciaram.

Torna-se difícil, portanto, avaliar a aparente maior eficácia das ações tradicionais em saúde, já que esta eficácia, por vezes, também acoberta intervenções que parecem ser mais uma profunda convicção do que um fato que se sustente cientificamente. Em relação ao controle de riscos, basta lembrar das dúvidas que pairam sobre a eficácia de boa parte dos procedimentos consagrados pela prática no pré-natal e no parto, por exemplo, e que vêm sendo apontados pelo estudo das evidências científicas, no movimento da medicina baseada em evidências (Enkin et al, 1995). Estas colocações visam apenas ressaltar o fato de que aquilo que é ou não realizado em termos de cuidado em saúde não se pauta estritamente sobre as evidências científicas de eficácia, mas muito mais sobre uma tradição de trabalho em saúde, que atende a necessidades sociais e historicamente construídas e não autonomamente estabelecidas pela ciência, como algumas vezes 
somos tentados a acreditar. Portanto, mesmo a argumentação dos profissionais acerca da eficácia ou não de determinadas ações deve ser examinada com cuidado e espírito crítico.

Devemos lembrar, uma vez mais, que trabalhamos com profissionais bem treinados e com supervisão constante, avaliados como desempenhando uma boa prática profissional. Portanto, a questão do erro médico e da negligência não são nossa questão de saída, embora na prática cotidiana nos serviços públicos possam ser um aspecto importante, ao menos em determinadas áreas de atenção. Queremos avançar a discussão das possibilidades no cuidado em saúde, e por isto não vamos nos ater a estes problemas, que são extremamente importantes, mas anteriores ao que estamos discutindo aqui.

As dificuldades e possibilidades apontadas pelos profissionais foram levantadas pelo roteiro semi-estruturado da entrevista, que abordam as categorias encontradas por Sugg e Inui (1992) em seu estudo, já relatado anteriormente. Vamos aqui retomá-las, comentando-as através das colocações de nossos entrevistados e de nosso marco teórico. Estas dificuldades foram divididas em cinco categorias por Sugg e Inui, como já dito medo de ofender, muito perto para acolher, perda do controle profissional, impotência e tirania da agenda (tempo).

Ainda que afirmem a conexão entre saúde e violência, os profissionais iniciam a entrevista dizendo que a violência (entendida como violência física) não se constitui como demanda para eles. Dizem ser raros os casos em que a violência aparece diretamente como problema ou conectada explicitamente a alguma demanda, ainda que eventualmente isso possa acontecer. No que foi visto até aqui e também no relato dos profissionais percebemos que há espaços para esta emergência, que concretamente ocorre. Quando o problema aparece desta forma, 
entretanto, é difícil que seja reconhecido como tal, qualificado e acolhido, e encontre, assim, possibilidades de resposta:

Que eu me lembre, até agora, me parece que foi uma só, porque estava tão evidente os roxeados no corpo, que mesmo assim eu acabei ficando na dúvida, porque ela falou que tinha caído. Então fiquei na dúvida, não consegui que se abrisse. Das outras pessoas é muito bem disfarçado, muito bem (auxiliar de enfermagem).

Algumas mulheres se queixam de terem sido espancadas, a gente ... né ... mas como eu não estou muito voltado para investigar o assunto, não é tão comum, mas já, algumas vezes aconteceu, de contar que apanhou do marido, isso não é tão raro, não (médico).

... Um outro grupo, que me parece o minoritário, também nesse sentido ele é outro pólo, em que isso não aparece conectado, mas isso é a demanda em si. A demanda em si. Eu acredito que, eu não conheço já pacientes que trazem a questão em si da violência ou problemáticas imediatamente relacionadas com ela como a própria demanda (médico).

Na visão dos profissionais, o problema não aparece preferencialmente como demanda imediata de violência física, mas, sim, "disfarçado". O que vem a ser este "disfarce" percebido?

Os profissionais percebem uma grande conexão entre violência, situações de sofrimento crônico e "difuso" e a demanda referida aos serviços. Para falar do impacto do problema na saúde, os entrevistados valorizaram uma definição de violência bastante ampla, enfatizando relações de gênero desiguais e injustas como condições muito comumente associadas a demandas percebidas como relativas à violência. :

Uma coisa que para mim é violência, mas elas nem caracterizam como violência, (é) transar sem querer. Toda hora que o marido quer, (ela) não sente prazer e ele também não se preocupa muito, às vezes porque brigou, porque ela está com raiva dele, porque ele bebeu, ou porque ele aprontou, porque quebrou tudo em casa ... sabe assim? E aí a coisa vem assim - mas por que toda vez que vou ter relação dói?-.

Ah, porque meu marido é muito grosso -, - mas é grosso por quê? -, e aí conforme também a situação, porque ninguém gosta de falar disso, é um assunto meio que proibido, porque é vergonhoso, como é que eu vou falar para uma pessoa que nunca vi, que eu apanho. Então às vezes esse assunto não é às claras. Às vezes, a gente dá dicas para ver se a pessoa se sente à vontade para estar colocando. Então, uma das coisas é essa: alcoolismo, - o marido bebe muito, e aí não tenho conseguido 
mais dormir. Eu ando muito cansada, deprimida, tem umas que têm vontade de desaparecer. Se sentem feias, horrorosas, acabadas. Quando faz o Papanicolaou, falam - ah, você acha que estou muito aberta por baixo? - algumas perguntam. Aí você vai ver - é que meu marido toda vez que transa comigo diz que não tem graça -. Sabe assim ... e a gente fala de violência doméstica, acho que não é só a mulher apanhar do marido ...

É tudo quanto é tipo de violência, tudo que me agride, tudo que agride a pessoa. É uma violência. Mesmo a mãe com relação ao filho. Quer dizer, tudo que agride o outro, que causa "chateação", mágoa, que me faz sentir muito mal, que me faz achar que eu sou um lixo, então a minha auto-estima vai lá para o pé, porque o outro está sempre me dizendo que eu sou feia, que eu sou gorda, que eu sou horrorosa, que já não mais o satisfaço. Ou, então, a partir do momento que ... o diálogo já não é mais o mesmo e a pessoa começa a se distanciar. Ou seja, quando a coisa não tem uma ... quando falta o respeito, de alguma forma. Quando falta o respeito é porque, para mim, é um problema que já começa na violência. Que a violência também é verbal, é o destrato (auxiliar de enfermagem, sublinhados nossos).

Então, assim, violência não é só quebrar o nariz. Então, no outro extremo, uma violência muito sutil, vamos para o outro extremo ... uma família com papeis muito rigidamente definidos, não deixa de ser uma violência sutil, leve, mas é uma violência também. Não vai apanhar, não vai quebrar a cara, mas também ... Quer dizer, se aí a gente for pegar todo o espectro, a gente vai ver um monte de coisas.

Enfim, por exemplo, eu citei esse exemplo para você, mesmo que não haja agressão física, o marido querer filho e não querer que a mulher faça contracepção é uma violência, claro, embora ela pode não apanhar, mas é uma violência.

Para ser muito genérico: qualquer coisa que interfira de modo sério na individualidade, que poderia ser de outra maneira, é uma violência (Médico).

Sempre vejo mais aquela coisa mais psicológica, violência psicológica mesmo. As mulheres, a maioria delas que a gente atende, principalmente por leucorréias ou dores, têm alguma pressão por conta do companheiro. Ou porque não engravida, ou porque ela quer engravidar e o companheiro não quer, ou porque acha que está muito larga, ou porque acha que não está sendo adequada para o companheiro, que o companheiro está se queixando, que não está bom para ele, certo, ou porque ela não está sentindo o prazer que gostaria que ele sentisse, enfim, e outra ... tudo passa na relação sexual. Que o homem não está muito preocupado com elas, então aí que é o depósito de esperma e acabou (auxiliar de enfermagem-sublinhados nossos).

É interessante perceber que relatos de violência física foram encontrados em 8,45\% dos prontuários estudados, e foram ouvidos em nossa observação das 
atividades grupais. Os entrevistados também referiram-se a casos em que a violência física era relatada no interior das ações em saúde, como vimos, ainda que seja percebido como um "assunto meio que proibido". O assunto é até estimulado a ser enunciado, como mostra a profissional que descreve o tipo de condução do diálogo (meu marido é grosso, - é grosso por quê?) que facilita sua enunciação. Mas apesar da emergência desta forma de relato no serviço, os profissionais enfatizam os conflitos de gênero ao conceituar violência (papéis rígidos, violência sutil, violência psicológica) e dão menor importância à presença da violência física.

Ao contrário da violência física, as relações de gênero no campo da sexualidade e reprodução são valoradas pelo serviço como parte de seu trabalho, têm propostas tecnológicas claras e todos os profissionais do serviço assumem uma posição solidária com o empoderamento das usuárias. Achamos que isto se dá pela implantação das ações programáticas e do PAISM, e a conseqüente operacionalidade conseguida pela idéia de direitos reprodutivos e sexuais na prática assistencial. As dificuldades neste campo podem ser escutadas, e a instituição como um todo não titubeia em "ficar do lado" da mulher em questões relativas à contracepção, por exemplo, ou de valorizar o direito de todas ao prazer. $\mathrm{O}$ atendimento à gravidez indesejada, por exemplo, tem padronizado de modo claro a postura institucional em relação à discussão de potencial desejo de interrupção da gestação, questão social e política bastante delicada. Basicamente, esta padronização recomenda o não julgamento e a aceitação da escolha da mulher, a orientação quanto aos potenciais riscos do aborto e o oferecimento do serviço para o cuidado à saúde, qualquer que seja sua opção - interromper ou manter a gestação (d'Oliveira; Senna, 1996). Esta postura "institucional" é seguida, com pequenas diferenças particulares, por todos os profissionais do serviço, independentemente de sua postura pessoal em relação à interrupção da gestação. Também as dificuldades com a contracepção são discutidas, sempre ressaltando a importância da participação masculina e instrumentalizando a mulher a realizar 
aquilo que deseja em termos de regulação (ou não) da fertilidade. Claro que alguns profissionais sentem-se mais à vontade do que outros para trabalhar estas questões, mas há sempre a possibilidade de recorrer a algum outro espaço, dentro do serviço, mais propício para este acolhimento. A presença de uma regulação clara para o trabalho destas questões facilita a postura profissional, que pode amparar-se em uma regra de conduta, resguardando o desempenho profissional.

A insistência dos profissionais do serviço pelo diálogo nas relações conjugais, que foi aqui exposta, é importante e demonstra um interesse na emancipação dos usuários, mas ao tratar da violência, percebemos um impasse. Devemos lembrar que uma parcela, provavelmente significativa, desta população atendida pode ser bastante vulnerável a situações de violência. Quando as relações conjugais tendem à violência, o espaço de negociação e diálogo está rompido ou tem grandes dificuldades de se estabelecer. A violência expressa a falta de poder, no sentido de comunicação "livre" e destrói a possibilidade de interação comunicacional, matando a possibilidade de geração de poder, de ação humana conjunta e solidária, como vimos. Neste sentido, a pouca visibilidade da violência pode ocultá-la como uma dificuldade muito concreta para o cumprimento da proposta do serviço (o diálogo, a interação comunicacional). Invisível, esta dificuldade não pode ser acolhida nem respondida, ainda que possa ser enunciada e até haja boas condições para isto. A falta de um projeto tecnológico que possa visualizar uma resposta possível "oculta" a violência no trabalho, e o problema passa a ser um obstáculo que não é possível enfrentar diretamente, na busca de melhores relações de gênero e melhor eficácia do serviço.

Talvez por isto, a violência física, embora presente, tenda a ser qualificada apenas indiretamente, enquanto a denúncia da desigualdade de gênero é enfatizada pelos profissionais. É a situação de sofrimento decorrente da falta de direitos humanos e injustiça nas relações interpessoais íntimas que é percebida como situação importante para a compreensão de muitas queixas aos serviços. 
Sabemos que uma parte destas situações inclui também violência física, e a entrevista com os profissionais reafirma a presença e simultânea invisibilidade deste fato no interior do serviço.

Outra razão desta ênfase no sofrimento crônico, em detrimento das lesões decorrentes da violência física, parece-nos ser a vocação de atenção primária do serviço estudado. É de se esperar que neste nível de atenção a demanda percebida como relacionada a sofrimentos advindos da violência seja mais relacionada a queixas crônicas do que a lesões físicas diretas provocadas por agressão física, sendo estas últimas mais facilmente referidas aos prontos-socorros. Talvez por lidar com problemas decorrentes de situações de sofrimento crônico, os profissionais tendam a enfatizar este sofrimento como mais importante, e não os episódios de violência física potencialmente presentes.

Note-se, também, que o problema parece ser percebido por meio de queixas variadas, algumas delas (estou "larga", não tenho prazer, estou me sentindo horrorosa), que são dirigidas ao serviço, mas geralmente não encontram respaldo em termos de ações técnicas tradicionais, enquanto outras (como leucorréias e dores) podem ser mais facilmente acolhidas e potencialmente tratadas pelos profissionais.

Alguns profissionais diferenciam, a partir daí, duas conseqüências possíveis da violência: as doenças de verdade e a somatização, percebida como falsa. Esta diferenciação será importante para a decisão sobre como a demanda será escutada, contida, qualificada e respondida.

Olha, eu acho que tem uma história a longo prazo, a pessoa estar mal consigo mesma, aí a saúde deteriora sim. Não de forma tão imediata assim, teve violência e vai ficar doente. Eu acho que a resposta mais imediata seriam aquelas somatizações, aquelas coisas comuns, que não são exatamente doença, mas são uma manifestação de uma certa, enfim, de uma certa importância. Então, somatizações, achar que está doente, hipocondria, aquelas coisas todas, que resultam de desajustes no qual a violência deve ser uma coisa importante. Agora, em relação a doenças mesmo, doenças manifestas concretamente no organismo, a somatização também é uma 
forma de doença, mas aquelas doenças mesmo, úlcera, câncer e tal, eu acho que a longo prazo tem a ver com uma pessoa que vive mal. Acho que a violência crônica configura uma situação de vida ruim, eu acho que sim, né. $E$ acho que a longo prazo essa situação leva a doenças, tipo câncer mesmo.

Eu desconfio que sim (as mulheres que sofrem violência usam mais os serviços de saúde). Acho que tem mais medo de doenças, sabe, aquelas coisas, a pessoa achar que está doente, e na verdade não está doente fisicamente. É muito comum em qualquer especialidade, na ginecologia também, eu acho que assim, as pacientes que a gente atende, uns 20 ... 30\%, são pessoas que não têm doença, mas acham que estão doentes, né. Isso é comum. E você tem que ver se estão doentes, você tem que investigar a doença, porque pode ser que estejam mesmo, né. Você desconfia que não estão, mas você não pode só pela conversa dizer que não estão. Então, eu acredito que a violência leve algumas pessoas a ter esse tipo de atitude, esse tipo de manifestação da tensão, que é achar que está doente, somatizar, acho que sim. Diretamente por causa do episódio de violência eu acho que não, porque se ela apanha dificilmente virá aqui depois de sofrer uma agressão. Mas eu acho que, nesse nivel de partir para a somatização, acho que sim, acredito que sim. (Médico destaques nossos).

O sofrimento crônico, na opinião dos profissionais, poderia até levar a longo prazo a doenças "de verdade", mas a associação principal e mais freqüente são as somatizações, problema comum que coloca a violência física e sexual e as relações de gênero injustas entre as causas das situações de sofrimento e "vida ruim e injusta" geradoras de uma demanda indesejável e de potencial baixa resolutividade. O profissional entrevistado alerta para o risco de desqualificação da queixa da usuária, quando a somatização é sugerida ainda na anamnese. O profissional pode cometer o erro de não seguir o trabalho até o fim, deixando de realizar com cuidado o exame físico e o pedido de exames laboratoriais para descartar uma possível doença do ponto de vista clínico. Parece-nos que este é um risco efetivo para estas mulheres: demandas que poderiam beneficiar-se da intervenção biomédica podem ser desqualificadas pelo enquadramento em um estereótipo: a somatizadora.

A idéia de somatização tem diversas nuances, mas a definição que vem sendo utilizada pela literatura médica diz que a palavra significa: “ uma tendência transitória ou persistente de experienciar e comunicar sofrimentos psicológicos na 
forma de sintomas somáticos e procurar ajuda para isto" (LIPOWSKI, 1968, apud SENNA, 1999).

Quando o problema for assim percebido, será trabalhado na direção que indica a idéia de somatização. Se a somatização é uma queixa de doença que não pode ser aceita como patologia (física), já que corresponde a queixas que não existem do ponto de vista do raciocínio clínico, é percebida por alguns de nossos entrevistados como uma manifestação física de sintomas psicológicos a partir do sofrimento cotidiano. Sem instrumentos para trabalhar a demanda assim concebida, os profissionais concluem que o problema deva ser manejado pelo técnico que detém o saber competente para lidar com a subjetividade individual: o psicólogo.

Em nossa percepção, este é um dos importantes motivos para o encaminhamento à Saúde Mental ser o preferido, quase a rotina nestes casos. Sem amparo na nosografia médica, a mulher que se sente doente é rotulada como "normal" do ponto de vista biomédico, e sua "anormalidade" é deslocada para a esfera psíquica. Este encaminhamento quase automático, sempre que uma demanda mostra-se sem perspectiva concreta de intervenção clínica, além de limitar o problema, pode ter um efeito desqualificador de sua demanda para a mulher. Percebido como algo de "sua cabeça", o encaminhamento pode reforçar a idéia de que os conflitos familiares são responsabilidade exclusiva da mulher e um problema decorrente exclusivamente de sua forma pessoal de se relacionar. Assim, várias de nossas entrevistadas tentavam esconder de sua família sua passagem pelo setor de Saúde Mental, porque eles poderiam usar este fato contra ela. Por outro lado, as mulheres reivindicam, como veremos, que seus maridos, sim, teriam uma doença mental, fato que não costuma ser acolhido pelos serviços.

A própria expressão "somatização" já parte de uma visão da relação corpomente bastante dual. A idéia de que as queixas corporais não estariam, na verdade, 
no corpo, mas sim na mente, e ainda por cima inconscientes, trabalha com esta concepção de delimitação dos limites entre corpo e mente de forma bastante precisa e excludente. O mal-estar proveniente da "vida ruim e injusta" expressa-se como sofrimento que pode ser, com sucesso, separado em corpo e mente do ponto de vista técnico pelo discurso competente de médicos e psicólogos, mas para as usuárias esta separação não tem o mesmo sentido. Se o que é considerado da mente é percebido (por usuárias e profissionais) como imaterial e "invenção", consciente ou inconsciente das mulheres, podemos compreender que a inconsciência seja a melhor forma encontrada pelos profissionais para explicar a somatização. Se esta "invenção" fosse consciente, as usuárias estariam propositadamente enganando os profissionais com as queixas, e esta grave acusação é sempre evitada, na tentativa de não culpabilizar as usuárias.

Por outro lado, para as usuárias, esta percepção da demanda e proposta de resposta pode parecer uma desqualificação do sofrimento, como se ele pudesse ser evitado por elas, se tivessem uma maior consciência ou uma melhor forma de relação pessoal, ou seja, por um ato de vontade individual.

Uma dificuldade para o "screening", apontada no estudo realizado por Sugg e Inui, foi o medo de ofender. Alguns dos profissionais entrevistados por nós tematizaram esta questão, ao argumentar que as mulheres são inconscientes da conexão entre o sofrimento, a violência e os seus problemas de saúde, e portanto não percebem que estão "somatizando". Assim, chamar a atenção para o problema poderia ser ofensivo, porque envolveria questionar aspectos da vida da mulher que não constituem demanda, e portanto, imputar-lhe problemas dos quais ela mesma não tem consciência.

Como já vimos, apontar problemas dos quais os usuários não têm consciência já é rotina na prática em saúde. O que importa aqui é a legitimidade 
deste tema como questão de saúde. Em nossa opinião, os profissionais precisam usar a inconsciência, no caso da violência, para explicar a difícil realidade percebida no cotidiano dos serviços: as mulheres buscam reiteradamente no serviço algo que, em sua visão, o serviço não pode oferecer.

Porque insistem tanto em uma doença que na verdade não existe? A maioria dos profissionais responde: porque elas não sabem que o problema não é uma doença, mas sua vida cotidiana, e que precisariam de outras ajudas, que não a médica. Nas palavras de uma auxiliar, estas mulheres procuram os serviços porque precisam de ajuda, mas de outro tipo, e são inconscientes disto:

eu acho que elas procuram o serviço de saúde porque estão pensando numa ajuda. Talvez ela não percebeu ainda se é ajuda médica, ajuda psicológica, que tipo de ajuda ... ou até uma ajuda legal. De repente ela nem percebeu isso, mas procura o serviço porque está pensando em algum tipo de ajuda. Ela não percebeu ainda que a violência que ela está sofrendo é violência de verdade, deve estar achando que faz parte, então ela está sofrendo por isso, está ficando doente, e ela não está associando as duas coisas, então ela vem para ver a doença, a questão da saúde, mas ela não consegue perceber que tem a outra história atrás. $E$ acho que inconscientemente ela vem procurar isso aqui (auxiliar).

Discutir o que a pessoa considera problema na sua vida, o que ela quer para si e que tipo de suporte acha que precisa não seria justamente uma das atribuições do cuidado, na atenção primária, pelo menos? Parece-nos que sim. É interessante lembrar que a insistência profissional em apenas escutar aquilo que possa ser enquadrado como patologia pode estar na origem da insistência das mulheres em “doenças" que não existem do ponto de vista profissional, como veremos.

Outros dos nossos entrevistados não compreendem assim o seu trabalho, e não acham esta divisão entre doença e somatização tão importante, argumentando que, independente de seu substrato anatomo-biológico, toda queixa deve ser acolhida pelo profissional de saúde. Para eles, a emergência do sofrimento associado à queixa deve ser ativamente estimulada para melhoria da qualidade assistencial, desde que se respeite o desejo da mulher de discutir a questão. Os profissionais não buscam aqui uma patologia, seja ela física ou mental, mas a 
compreensão de um sofrimento, de um "modo de andar a vida" alterado. Neste caso, a solução antevista não é sempre, de saída, a saúde mental, mas este tipo de atendimento tende a compor um leque mais amplo de possibilidades de resposta a ser discutido com cada mulher, a partir de seu conjunto de questões e a depender da disponibilidade destas respostas diferenciadas. Estes profissionais argumentam, entretanto, que as mulheres, muitas vezes, recusam-se a abordar ou intervir sobre o problema, por terem construído, de alguma forma, sua subjetividade em torno da violência, e não reconhecerem a situação como um problema a ser transformado.

Estes profissionais lembraram de ocasiões em que a situação de vida relatada é percebida como violência pelo profissional, mas não parece ser assim tematizada pela mulher. Nestes momentos, deveria o profissional apontar para ela um potencial problema na sua vida pessoal que ela mesma parece não reconhecer? As auxiliares mencionam que muitas mulheres relatam a violência física ou as restrições e constrangimentos como algo banal, rindo, e não tematizam a situação como um problema. Devem os médicos e auxiliares de enfermagem apontar o problema? Qual é o limite da intervenção profissional? Até onde devemos cutucar, para usar a expressão de uma das profissionais entrevistadas?

Apesar do receio de abordar temas polêmicos e que envolvem diretamente dimensões muito mais amplas que a da patologia, os profissionais do serviço, habituados com as ações relativas aos direitos reprodutivos, percebem como sua responsabilidade profissional investigar ativamente a presença destes temas, quando parecer indicado ( conexo à ação terapêutica) e viável:

às vezes a gente conduz, conforme o atendimento, o "papo", às vezes eu até pergunto, conforme o que está rolando, às vezes, me sinto com mais liberdade para falar. Da mesma forma quando a gente sente, às vezes, que a paciente talvez esteja querendo fazer um aborto. $E$, às vezes, a gente pergunta. Depende, depende da relação que se estabelece ali no momento. Depende do que ela quer (auxiliar de enfermagem). 
Nossa, às vezes a gente escuta cada coisa $e$, às vezes, a gente não escuta, mas aí eu tenho esse direito, se, às vezes, a pessoa não quer me falar porque tem vergonha, ou então porque ainda para ela não está muito claro, ou está sofrendo muito com isso, mas não quer abrir. Você entende? Não sei qual é o termômetro, de até que ponto eu posso ... esse é o medo meu, o medo que a gente tem, até que ponto eu posso levantar um assunto e que então eu posso não dar conta mas eu posso trazer mais angústia ... mais amargura, para uma pessoa. E eu não quero isso, você entendeu? Por isso que eu falo, com algumas pessoas até a gente consegue, porque no fundo é isso que ela quer, ela vem com essa demanda e ela fica ... insiste ... aí você vai caminhando ... até uma hora que ou ela fala ou você pergunta: - você está sofrendo algum tipo de violência? Está acontecendo alguma coisa? -, tem horas que vai indo, vai indo e você consegue fazer isso.

E tem outras que você percebe aquela angústia, mas a pessoa - não ... -, quando você pensa que ela vai chegar lá, ela ...: sai, aí muda de assunto. Aí que eu falo, será que é para eu ir até o fundo e abrir um pouco mais a ferida no peito dessa pessoa? E aí? Eu não acho isso certo, isso para mim também é uma questão. (auxiliar de enfermagem)

Este cuidado do serviço em não adentrar a vida privada da mulher contrasta com a facilidade com que isto acontece cotidianamente em outros assuntos já tradicionais da prática médica, como a sexualidade e o uso de drogas, que são perguntados sem rodeios. Ao abordar a violência doméstica, no entanto, parece haver um cuidado muito grande dos profissionais em não normatizar a vida privada das mulheres. Este cuidado, que é muito importante no sentido de "respeitar a mulher como sujeito de sua vida" e não invadi-la com prescrições sobre temas para os quais o saber biomédico não tem respostas, pode, por outro lado, vir a obscurecer o problema e dificultar sua enunciação e acolhimento:

uma das coisas que eu nunca faço, por exemplo, se estou percebendo que tem alguma violência atrás de algum atendimento que estou fazendo, eu não invado, não consigo ... sabe ... nem sei como se fala, qual seria a palavra, mas não vou ficar "cutucando" para ela falar. A gente percebe, a gente acha que tem essa sensibilidade de poder saber se a mulher está pronta nesse momento para abrir o jogo ou não. Então, eu acho que tem um momento que você pode até dar umas "insinuadas" para saber o que tem atrás do atendimento, do corrimento, da dor, enfim ... Eu só vou apontando coisinhas assim - tudo que tem a ver com a parte de baixo tem a ver com algum homem ... pode ser teu marido, namorado, um pai ... alguma coisa tem a ver com homem, porque as queixas das mulheres daqui de baixo tem a ver com sexualidade, sexo -, aí a pessoa começa a pensar, vai abrindo ... Se acabou ali, fechou ali, também não insisto, ela não está pronta para contar nada. Então acho muito delicado, fico até com um pé atrás. Talvez até tenha passado 
muitas vezes algum atendimento, que eu não tenha ido um pouquinho mais porque eu fiquei com um pouquinho de receio (Auxiliar de enfermagem).

Como saber " aquilo que a mulher quer", o limite estabelecido na relação entre o desempenho profissional e a invasão pessoal? Como reconhecer os limites da ação profissional?

Se as desigualdades nas relações de gênero parecem ter repercussões para a saúde reconhecidas por todos, a emergência da violência, seu acolhimento e resposta enfrenta, portanto, vários obstáculos, e é polêmica entre os profissionais. Devemos lembrar novamente que este reconhecimento torna-se claramente mais difícil quando questões éticas tão delicadas estão colocadas e o serviço não possui uma regra clara que uniformize a conduta profissional.

Os profissionais que se situam no pólo mais tradicional do trabalho percebem seu saber técnico como qualificado para diagnosticar e tratar de doenças e argumentam falta de capacitação para lidar com os problemas da vida da mulher. Por isto, tendem a enfatizar a importância de ações eficazes e bem sucedidas e recusar a idéia de buscar este tipo de questão ativamente ou facilitar a sua emergência. Alguns argumentam ser uma irresponsabilidade perder o tempo que possuem para falar com as mulheres de problemas para os quais não têm treinamento e não vêem possibilidade de intervenção com alguma eficácia, quando tantas mulheres necessitam daquilo que eles podem realizar com certeza, o tratamento das doenças. Já que não há doenças para diagnosticar e tratar, não há cuidado possível a prestar. Quanto à violência, um dos médicos tem dúvidas quanto à pertinência de sua busca, por falta de perspectiva de alternativas de resposta antevistas:

Tem uma série de coisas na anamnese médica que a gente pergunta e que tem que saber, independente se vai ajudar ou não, antecedentes, que você tem que saber para caracterizar o paciente, mas daí para frente, eu costumo só abordar as coisas que vou trabalhar em cima. Eu tenho medo de levantar a questão e depois deixá-la de lado.

A violência não faz muito parte, vamos dizer assim, da investigação das 
doenças, da saúde da pessoa. Claro que é importante a violência, mas do ponto de vista de detectar as doenças, não é uma coisa tão importante assim. Imagino que não seja. Portanto, ela não faz parte da anamnese médica básica, tradicional.(...). Eu acho que a formação da gente não é para ... não é muito adequada para abordar dificuldades na vida sexual, porque basicamente não são problemas ginecológicos. Quem tem formação acho que é o psicólogo, psiquiatra, gente com formação na área da psicologia, eu acho. Então, mas por outro lado, a gente ouve muita queixa de sexualidade. A ligação que a gente tem com isso são duas: a contracepção que entra um pouco, na questão, não muito, mas entra um pouco e as mulheres acham que o ginecologista é quem mais entende de sexualidade, isso é uma coisa padrão.

Dizer, por exemplo, essas são coisas que eu faço quase todo dia, que o fato de ter perdido o interesse ou de não ter interesse na sexualidade com o parceiro não é doença ginecológica. Isso eu digo para todas, porque elas acham que estão doentes, que têm que tomar algum remédio. Isso é fundamental. Então, nesse nível eu entro, agora, para melhorar a situação para ela, realmente não tenho formação para isso (Médico).

O profissional não tem saber que oriente um trabalho eficaz nestes casos. Por isto, tenderá a não valorizar a queixa, dedicando seu tempo, sempre limitado, a problemas para os quais pode ter resposta. Mas o problema da sexualidade ou violência continua e muitas outras mulheres seguem pedindo respostas aos serviços, o que faz com que nosso médico tenha que repetir incansavelmente que aquela anormalidade percebida como tal não é uma doença. A impotência percebida está associada com a falta de um saber operante que dê sentido tecnológico a esta demanda, já que o existente pode reconhecer apenas aquelas queixas potencialmente catalogáveis como doença.

Por outro lado, este profissional remete para outros espaços do serviço estas queixas "incômodas", respondendo de alguma forma à demanda. Informado de que o serviço implantaria um serviço de aconselhamento para a violência, o médico prontificou-se a detectar e encaminhar os casos.

Porque as mulheres insistem em imaginar que o ginecologista entende de sexualidade? Temos que lembrar que os médicos perguntam sobre o assunto, em sua anamnese "clássica", e tem termos próprios para designar as anormalidades nesta área (frigidez, impotência, dispareunia...). Também falam sobre o assunto na 
mídia, e efetivamente tratam os problemas relativos, tendo até recentemente descoberto uma droga nova de grande repercussão mercadológica e na mídia (o Viagra). Do ponto de vista das usuárias, por outro lado, separar com clareza sexualidade e reprodução, violência e problemas de saúde, é um desafio incontornável. A idéia de que o ginecologista não entende de sexualidade, portanto, embora possa ser verdadeira (a formação profissional é bastante precária no tema), é bastante contraditória. Como diz o médico entrevistado, a sexualidade é e não é problema da prática médica.

Para as mulheres, é possível perceber qual a vocação de cada lugar de assistência e suas regras de linguagem, e apresentar queixas ginecológicas quando se quer falar de sexualidade, fazendo o deslocamento discursivo apontado, para tentar a interação possível quando o serviço não se propõe a discutir o tema.

Se não há doença, não há resposta? Como convencer estas mulheres de que o que sentem não é doença, se a anormalidade percebida continua e os serviços de saúde são insistentemente apontados como o lugar para resolver este tipo de queixa? Esta parece ser uma das grandes questões para os profissionais, já que os problemas percebidos encontram-se fora do campo considerado como seu agir profissional. Por outro lado, as mulheres continuam sentindo dores e anormalidades, acorrendo aos serviços e, de uma forma ou de outra, sendo acolhidas. Ainda que seus problemas de vida familiar não possam ser ouvidos, aquelas queixas, com alguma probabilidade de caracterizarem doenças, são investigadas, alguns medicamentos são prescritos, alguns sofrimentos mitigados e o círculo, realimentado.

Torna-se um pouco mais claro, assim, porque os relatos de sofrimento e violência parecem aos profissionais "escondidos". Se as queixas que não podem vir a ser rotuladas como patologias têm dificuldades para ser escutadas, na maioria dos serviços, e a violência é pouco acolhida até no CSE, elas têm também muito 
menor chance de ser enunciadas. Na busca de se fazer escutar em seu sofrimento, as mulheres, na tentativa de serem acolhidas e qualificadas, deverão lançar mão do deslocamento discursivo aqui discutido, enunciando o seu sofrimento na "linguagem" da doença (física). Claro que a correta (do ponto de vista biomédico) resposta profissional a esta linguagem, em seus próprios termos, ou seja, a procura conscienciosa de eventuais patologias, colabora com a reiteração da somatização percebida, mas a maioria dos profissionais não parece ter consciência disto.

Portanto, não nos parece que seja tão evidente que as mulheres escondam deliberadamente a sua situação, mas, sim, que o enunciar do problema em termos de queixas e sintomas físicos é fruto da interação de médico/enfermeira e paciente, mediados pela anamnese e o exame físico da consulta médica. Este deslocamento pode vir a diminuir a potencial eficácia do trabalho, se percebido em sua finalidade última de cuidado em saúde, e não apenas descoberta e tratamento das patologias.

A percepção do sofrimento gerador de queixas para os serviços de saúde, para as quais não tem recursos técnicos para o trabalho, dão aos profissionais entrevistados uma sensação de impotência e perda do controle profissional.

O saber técnico-científico não tem resposta para oferecer, quando não há doença ou risco detectável que mereça alguma intervenção, e fica sem saber como lidar com o assunto na maioria dos serviços. Mesmo no CSE estudado, onde as desigualdades de gênero são ativamente discutidas, esta sensação aparece sempre que não há resposta técnica prevista. Como diz uma auxiliar de enfermagem, referindo-se a um relato de caso de uma mulher com múltiplas queixas, em que ela percebe uma situação de conflitos acerca de direitos reprodutivos:

Não tem nada que tratar nela... isso que é pior, porque se tivesse alguma coisa, acalmava um pouco.. (auxiliar de enfermagem).

A perda de controle profissional, citada por Sugg e Inui (1992), também foi lembrada como dificuldade para o trabalho, porque, na visão dos profissionais, a enunciação e superação do problema deste tipo dependem mais da ação da mulher 
do que da ação profissional. O serviço de saúde, acostumado a deter os instrumentos de intervenção e o sentido do trabalho, como é o caso extremo da cirurgia, tem dificuldades para lidar com tema como a violência, situação em que não reconhece as ferramentas necessárias para operar e na qual a autoridade sobre o momento e forma de "intervenção" depende basicamente da mulher. A perda de controle está associada aqui, portanto, à impotência.

Nesta situação de impotência, medo de ofender e perda de controle, os entrevistados têm posições que recomendam cuidado ao abordar o tema, pois ele não pode ser " curado" e pode provocar malefícios imprevisíveis:

Tem até um ditado que uma vez a gente colocou aqui no nosso quadro - não cutuque na ferida se não tem como curá-la (risadas).

Porque a gente pode, profissionalmente, como uma entidade de saúde, a gente pode fazer os encaminhamentos, mas não vai resolver a vida dela. A gente pode falar - olha, vai lá naquele lugar que você vai ficar protegida, você e seus filhos -, mas e daí? E depois? O que ela vai fazer da vida dela? Ela e os filhos? O serviço vai atender ela? Vai dar o sustento para ela? Não vai. Então, é muito difícil mesmo (auxiliar)

A perda de controle cria uma aflição para os profissionais, de perceberem que não controlam os resultados de seu trabalho até o fim. Se encaminharem, os profissionais não podem garantir o bem-estar da mulher fora de seus domínios, e não terão controle dos resultados (imprevisíveis) de sua ação. Daí que achem, algumas vezes, melhor nem fazer nada. Mesmo acolher e encaminhar, que é reconhecido como potencial tarefa dos serviços nestes casos, é difícil para alguns:

Eu não me consideraria preparada, não, porque se é para fazer a questão burocrática, escutar a história, depois anotar e encaminhar acho que isso não é o atendimento adequado. $O$ encaminhamento serve muito, mas não é aquela coisa que você ouve e - então, você vai para tal lugar resolver isso ... -.

Porque eu vou ouvir, mas ela vai querer que eu fale alguma coisa. Que será que eu posso falar?

Até onde eu posso chegar? Não posso me intrometer pessoalmente na vida da mulher. Tenho que falar como profissional, não posso misturar, eu estou representando um serviço, e não estou representando eu mesma. Estou representando eu mesma entre aspas (auxiliar de enfermagem).

Preocupada com o seu lugar profissional, a auxiliar teme colocar suas posições pessoais no interior da ação técnica. Tem medo mesmo de abordar o 
assunto, ainda que seja apenas para encaminhamento, trabalho que tradicionalmente está habituada a fazer. Entretanto, enquanto não vê problemas em informar sobre uma referência para o diagnóstico ou tratamento de câncer, no caso da violência não se sente habilitada, por não saber distinguir o limite da ação profissional e a interação humana. Certamente uma postura institucional quanto a estes casos facilitaria o seu trabalho, mas serão estes limites assim tão bem delimitados?

Informar sobre os recursos existentes na comunidade para o trabalho com a violência não é, entretanto, tão ameaçador para a outra auxiliar de enfermagem, que se sente no dever de fornecer esta informação e a considera parte importante de sua ação profissional.

Tem que ser educativo em primeiro lugar. Acho que as mulheres têm que ser informadas que existem esses órgãos que são a delegacia da mulher, desmistificar um pouco, porque o que existe de fato, apesar que aqui em São Paulo parece que está meio que "capenga", né, essas casas de apoio, tudo mais. Mas eu acho que é isso, informar que existe. Porque assim, algumas até vão, vão na delegacia normal, por exemplo. E uma delegacia normal, muitas vezes, é mais complicado.

Então, quando eu falo de dar informação, a gente tentar desmistificar um pouco e até trabalhar com essa coisa de que tem um número muito grande de mulheres que sofrem violência, sim, em diversos graus. Então, isso acho que é legal elas saberem, que não é eu, não é você ... eu tenho com quem me juntar, com quem me ligar. Saber que talvez aquela companheira que está sentada do meu lado também sofra. E talvez esteja que nem eu - será que falo?, será que não falo? -, a gente tem vergonha de repente ... eu faço uma imagem de mim de um jeito aí fora $e$, às vezes, vou ter que tirar a máscara, todo mundo tem uma máscara, não tem? (auxiliar de enfermagem).

Esta profissional vê a informação e o posicionamento contra a violência como parte de seu trabalho, respeitadas as opções da usuária. Acusa ativamente o caráter social do problema para as mulheres, ao lembrar que existem muitas outras nesta situação. Ela conta alguns "casos" em que sua orientação foi bem sucedida e que ela considera como de sucesso profissional. Vemos que quando o problema pode ser recortado como conflitos nas relações de gênero, e não somatização, como é o caso da operacionalização do PAISM e da integralidade neste serviço, há realmente expansão das possibilidades de cuidado e um novo lugar para as ações de saúde mental no caso relatado por esta mesma auxiliar de enfermagem: 
Teve um caso de uma paciente que eu atendi, que ela tinha dois filhos adolescentes, trabalhava fora, o marido também trabalhava e os filhos já conseguiriam ajudá-la no serviço doméstico, que era uma coisa que ela sempre pedia, que ela chegava do serviço cansada, mas o marido sempre chegava antes que ela. Ela não tinha carro, dependia de ônibus, então ela chegava em casa nessa época e as filhas adolescentes, que já estavam em casa, que podiam deixar uma janta adiantada, uma casa mais ou menos apresentável, não se tocavam. Ela se sentia super mal cobrando das filhas. $O$ marido chegava e ficava lendo jornal na sala. $E$ quando ela chegava, a primeira coisa - oh, estou morrendo de fome, não tem comida nessa casa? - Entendeu?

E ela falou que nessa época já estava com o saco tão cheio, tão deprimida ... foi quando ela veio fazer um Papanicolau, fazia não sei quantos anos que ela não fazia Papa. e ela não conseguia arrumar um tempo na vida dela para fazer Papanicolau. Estava com minhocas na cabeça, achando que lá dentro estava tudo um horror. Aí ela veio, ficamos conversando. A gente primeiro faz algumas perguntas e aí foi surgindo, e ela toda derrubada, caída, muito triste, aí ela falou - ah, será que eu posso perguntar uma coisa? -, eu não sei se sou eu que atraio esse tipo de conversa, mas é o maior barato. Assim, não é só fazer o Papanicolau, não é só fazer o atendimento. A gente acaba conhecendo um pouco as pacientes e tal. Eu sei que no meio da conversa ela falou que estava muito cansada, muito desesperada, porque ela se achava feia, horrorosa, que o homem já não procurava daquele jeito. E que se ela revidasse, ficasse " $p$ " da vida, ele gritava com ela, não batia ainda. E a mesma coisa com as adolescentes, que ela teve que trabalhar, para dar tudo para elas, que elas gostam de andar bem arrumadas e tal. $O$ marido não valoriza isso. Eu sei que conversamos, conversamos, um monte, sobre a vida, sobre relacionamento, sobre 0 que ela poderia estar fazendo para melhorar um pouco essa situação. Que em primeiro lugar ela que tinha que mudar, se ela quisesse que mudasse alguma coisa. Tinha 20 e tantos anos de casada. Mas a primeira mudança que eu achava, que ela achava que era legal era ela tentar mudar ela, ela começar a achar que ela tinha 40 e poucos anos, mas que ela ainda tinha muita coisa para fazer por ela. Começar a se gostar, ela não se arrumava mais, não cortava o cabelo direito, não se pintava ... porque como era para ela, então a vida tinha acabado. E estava muito deprimida em todos os sentidos.... Eu sei que a gente ficou um tempão conversando. Aí no retorno ela já veio diferente. Aquela conversa surtiu efeito. Que quando fui chamá-la na sala de espera, eu já não acreditei, eu já vi uma outra mulher, outra mulher. Eu sei que ela estava pintada, com o cabelinho cortado, com brinco, maquiada, tinha colocado uma roupa, e o que mais me chamou a atenção era a postura, sabe assim, a forma como ela te vê, uma coisa diferente. Um sorriso... Ela falou - olha, no dia que eu saí daqui comecei a pensar muito na minha vida, que durante muitos anos eu me dediquei ao meu marido e meus filhos. E continuo, trabalhando, me dedicando... e já não existe mais aquilo... Em vez de comprar tantas roupas que as filhas pediam, começou a comprar para ela, começou a se pintar, começar a se olhar no espelho, a falar que ela se gostava e quando chegava em casa cansada começou a brigar, que quem quisesse, que os três estavam lá, e que ela era a última a chegar, que se todo mundo cooperasse a comida ia sair mais cedo, a casa ia estar melhor arrumada, se todo mundo se esforçasse. Eu sei que não mudou, lógico, não deu uma mudança 
radical na vida dela, mas ela conseguiu fazer alguma coisa por ela e ela está super feliz com as coisas que ela está. Começou a ir na (saúde)'mental' até, que foi uma das coisas que eu sugeri para ela. Então, assim, e não era um tipo de violência que ela estava sofrendo? Eu acho que era, porque causava sofrimento, ela se sentia super mal.

Note-se que a auxiliar recortou o problema bem mais amplamente do que apenas o Papanicolaou para sua ação profissional, e realizou uma "intervenção" completa, no sentido de uma maior liberdade comunicativa, que tem como um dos desdobramentos o encaminhamento para a saúde mental. É esta tradição de trabalho com as relações de gênero que faz com que também a violência, no sentido que estamos usando aqui, possa ser escutada e acolhida em algumas situações, como vimos.

Sintomaticamente, a categoria muito perto para acolher só foi tematizada pelas auxiliares de enfermagem. Os médicos, não se percebem muito perto para acolher, já que são homens, brancos e pertencem a uma camada social diferente das usuárias. As auxiliares de enfermagem, entretanto, percebem fortemente esta questão e sentem-se muito perto. As duas entrevistadas contam casos de violência ocorridas com elas próprias, mas trabalharam este tema em direções opostas. Uma delas afirmou que esta proximidade era um fator importantíssimo para não procurar ativamente o problema, já que como mulher também sofreu violência e preferia esquecer:

Sim, sou mulher também. Em algum momento da minha vida devo ter sofrido alguma violência também $e$, de repente, não estou lembrando neste momento. A gente bloqueia, quer esquecer, quer deixar para lá, qualquer desculpa a gente inventa, né. Mas pode ser, isso aí é tranqüilo.

Se não foi com o marido, com algum namorado, com o pai ... Meu pai me dava umas surras violentas, então, de repente, pode ser. Minha mãe também, me surrava ... mas era assim que criavam os filhos, né, antigamente ... Os meus pais eram assim, eram na base da surra (auxiliar de enfermagem).

A outra entrevistada considerava importante levantar a situação justamente por reconhecer-se como mulher em situações semelhantes. Esta profissional comentou que já "chorou junto" com as usuárias, e colocou esta proximidade como 
uma motivação para o trabalho. Considera fundamental mostrar para a mulher que ela não está só, e que o problema pode ser de muitas outras como ela. A sensação de estar muito perto, portanto, pode dificultar, mas pode favorecer o relato de sofrimentos e violência, seu acolhimento e eventual resposta. Em nossa opinião, estar perto pode ser útil, quando a postura técnica e profissional pode não ser ameaçada por esta proximidade.

A profissional que se sentia no dever de aconselhar e referir ainda tem, entretanto, dúvidas sobre quando e como intervir. Informa sobre os direitos e solidariza-se com a usuária, que deverá decidir sobre suas opções de vida e responsabilizar-se por elas, mas angustia-se quando tem opiniões diferentes da usuária sobre o que venha a ser "vida boa" e violência.

A profissional que, ao contrário, prefere não levantar a questão, o faz por temer desencadear ações e opções sobre as quais não tem controle, mas entende que continua responsável. Assim, se a mulher optar por procurar um abrigo, porque foi informada de que ele existe, imagina que a vida dela depois desta opção passaria a ser responsabilidade do serviço. Ela não percebe a orientação como seu papel e tem dúvidas apenas sobre quando pode falar sobre o assunto sem ser invasiva. Ela não entende seu papel em uma situação em que não possa manter totalmente o controle do processo de "intervenção". É interessante perceber que o trabalho em saúde depende sempre, em menor ou maior grau, da "colaboração" do paciente, e o controle profissional sobre o cumprimento das prescrições é sempre problemático (basta lembrar do clássico assunto da aderência). Geralmente, o não cumprimento (pelos usuários) das recomendações feitas pelos profissionais do serviço tende a ser considerado responsabilidade exclusiva dos usuários. Neste caso (a violência), entretanto, a informação (casa-abrigo, por exemplo) não deveria ser, de forma alguma, uma prescrição, mas, antes, uma informação que deve ser examinada pela mulher, se possível, com apoio profissional. Não faz sentido, se respeitada a autonomia da usuária, o serviço responsabilizar-se por decorrências 
de sua decisão, a partir da informação recebida. Guardadas as proporções, o serviço não costuma se sentir responsável pelos bebês nascidos de falha de suas orientações contraceptivas, mas sente-se por suas orientações acerca da violência.

Parece que as duas profissionais, no fundo, sentem-se profundamente responsáveis por suas pacientes. A diferença é que uma delas evita um assunto que lhe parece estar fora de sua atuação profissional, enquanto a segunda o inclui na sua atuação. Esta inclusão, entretanto, traz novos problemas: como respeitar as opções da mulher e, ao mesmo tempo, colocar-se como profissional e mulher quanto a estas opções? O limite da atuação profissional está novamente colocado aqui, mas em outras bases.

Por fim, o tempo (tirania da agenda) não foi uma questão que pareceu muito importante para os profissionais entrevistados, provavelmente por causa da estrutura de atendimento, que não exige uma grande produtividade dos profissionais, mas sim cumprimento do horário, cuidado e qualidade com a produção realizada. Apenas uma auxiliar apontou o tempo como questão. Um dos médicos disse que o problema não era evidentemente o tempo, mas sim a pertinência da questão ao seu trabalho. Este profissional levantou, entretanto, o serviço como uma instituição com um papel no trabalho com o problema, e preferiria referir para outros profissionais e espaços de atenção os casos eventualmente detectados por ele.

O outro pólo apontado como muito importante para a possibilidade ou não da emergência e eventual resposta ao problema são as usuárias. É a sua consciência sobre a situação e seu uso de serviços, articulado nas estratégias e lógicas de sua vida que, na visão dos profissionais, dá sentido final ao trabalho e ampliam ou reduzem as possibilidades de fala e outras ações sobre o sofrimento subjacente. As opiniões das usuárias e o que elas realmente querem, entretanto, são, algumas vezes, bastante diversas da visão profissional, e também trazem críticas à ação 
profissional. Vamos ouvi-las novamente, agora, falando sobre violência, saúde e uso de serviços.

\subsection{As usuárias}

$\mathrm{Na}$ visão das usuárias, a violência está associada a transtornos físicos e mentais, tanto imediatamente como a longo prazo. Esta associação é tão clara para a maioria delas que não precisa ser justificada. Vivendo em um contexto em que a violência está presente a ponto de ser banalizada, Marluce apresenta sua situação de vida, saúde e uso de serviços, para ela e a família, integradamente:

Ah, eu acho ... ( que tem problemas de saúde por causa da vida que levou). Eu tenho um negócio aqui na cabeça, uma cicatriz, que quando eu fiz isso na cabeça, eu fiquei desmaiada muito tempo, não sei quantos dias, não sabia se eu vivia, se eu morria. De uma pancada que eu levei na cabeça. Às vezes você está menstruada, você leva uma pancada, dói naquele lugar, dói tudo assim na barriga. Quando meu pai me batia, às vezes, eu doente, meu pai me batia ... batia na minha mãe, minha mãe cheia de problemas, por quê? Eu tenho uma irmã que tem problemas de saúde, porque o marido dela bateu tanto na barriga dela ... que deu um negócio na barriga dela ... eu não sei o nome da doença ... E ela vive com ele, aí eu xingo,... porque o pai é diferente, você apanhar do seu pai ... é diferente de você viver apanhando do homem. Que nem esse aí, no começo, só que era assim ... ele me dava uma, eu dava duas nele também ... não pensa você que eu apanhei sozinha não, porque eu tenho provas até hoje, ele já perdeu a visão, já perdeu a memória, porque eu bati nele, dei uma pancada na cabeça dele e deu coágulo ... O médico falou -... só pode ter sido uma pancada, o que provoca isso, essa coisa que ele está -, aí eu falei - ah, doutor, ele me batendo no meio da rua, na cara, e eu pá!, na cabeça dele também, deve ser isso.

O médico deu risada ...

\section{(..)}

As pessoas vivem falando que, às vezes, o nervoso que faz tudo, né. Porque é engraçado, quando eu passo nervoso, eu não durmo. Nem ele ... eu falo - hoje você não dorme -, e não dorme mesmo, que eu percebo que ele mexe na cama, ele não ... ele levanta, é a mesma coisa, acho que todo mundo, quando você passa um nervoso assim você não consegue ficar calma. Eu não consigo dormir. E eu sinto dores ...quando fico nervosa sinto dores. Aquele dia que estava nervosa eu sentia tanta dor que parecia mentira que eu estava com dores. Aí, quando não estou com uma coisa, aí eu não sinto muita dor (Marluce). 
Marluce associa seus problemas de saúde também ao trabalho pesado que exerceu em toda a sua vida. Para ela, suas queixas estão relacionadas com as relações interpessoais e o trabalho que teve durante a vida.

Claudia, outra de nossas entrevistadas, associa tão fortemente seus sintomas com a sua situação de vida que as dores são relacionadas diretamente ao marido, identificado como o agressor:

Sempre... que faz frio, eu não gosto de frio, então o meu marido tem a ver com frio. É uma pessoa que o frio me lembra ele. E é só fazer frio, eu tenho dor de dente. Se eu ficar num ambiente quente, me dói o dente, aqui tudo dói, tenho raiva dele. Então, eu... eu... eu assimilo assim, ele, o frio e a dor. São as três coisas que vivem junto. Eu descobri, porque eu não sabia de nada. E aí, eu ter dor no braço, tenho raiva dele.

Me deixou quase morta. Eu já tive tanta dor... Ele tem a ver tanto comigo, com a minha saúde, com o meu "eu", que quando ele se aposentou, que eu tomei conta que esse homem ia ficar em casa, eu caí doente, de ficar três, quatro noites, dormindo sentada no sofá e ele... e ele feliz da vida prá lá, nunca perguntou "melhorou?", qualquer coisa. (...) E uma depressão tão grande, tão grande, tão grande; uma mágoa tão grande, que não tinha cura prá reparar. E ele tá no meio. Ele tá no meio.

Cada vez que aconteciam as brigas, eu sentia assim, meu corpo desmoronar, meus braços desfalecer e vontade de morrer. Sempre vontade de morrer. Sempre que..., que eu ficava assim, tinha as brigas, tudo; quando eu me enchia de coragem assim prá me separar, tal e coisa, ficava doente. Adoecia. Adoecia mesmo..., até hoje, se eu fico nervosa, assim com ele. E com outras coisas, raramente, eu fico nervosa. Tudo eu tenho assim, um controle. Eu tenho dor de dente; dor de ouvido, me dói o braço. E quando está tudo bem, que eu estou assim, que eu estou numa boa assim, que já passou, que já passou aquela fase das brigas, das coisas, aí eu estou bem (Claudia).

O relato de Claudia é sugestivo, porque descreve uma relação circular entre a violência e os problemas de saúde. Parece que para ela o problema de saúde percebido decorre da situação de violência, mas, ao mesmo tempo, impede (fisicamente) que ela saia da situação. Circularidade esta geralmente invisível para os serviços...

Ela chama a atenção para o fato de que a consciência da conexão entre a violência e os problemas de saúde ter sido uma aquisição, uma coisa que ela 
"descobriu". Ela primeiro "não sabia de nada". O processo de descoberta de Cláudia (ela é nossa entrevistada mais velha, com 59 anos) é longo e foi, no seu entender, fruto de diversos tipos de terapias psicológicas e de consultas homeopáticas. Se para Cláudia esta conexão é muito clara, ela é diversa entre as entrevistadas. Enquanto Claudia afirma que deve cuidar de si para melhorar sua situação de vida, e que foi assim que melhorou os seus sintomas de dores no corpo (diagnosticadas clinicamente como artropatias), as outras mulheres, apesar de concordarem genericamente com a relação entre os problemas em sua vida e os sintomas de saúde, não pensam em agir sobre a vida para melhorar seus sintomas, mas exatamente ao contrário: buscam reparar o corpo e seus sintomas para melhorar sua vida.

Além das queixas físicas, o nervosismo também é associado à violência, passada ou presente, e compromete a saúde:

Esse problema de nervo meu, mesmo, acho que vem da minha infância. (Chora) ...(Carla)

Eu era ... até 18 anos eu era muito feliz ... agora estou com 25 anos e é a mesma coisa de eu não ter nada. Porque ser uma pessoa assim ... agora ... antigamente eu não tinha nervoso, agora eu sou nervosa, qualquer coisinha eu estou brigando ... Então, eu falo para ele, pode se dizer que foi ele que destruiu minha vida, porque eu não era desse jeito. Estou com ele assim ... por estar ... porque eu não sinto mais nada por ele. Eu moro com ele assim por morar (Elza).

Ser nervosa, para Elza, é o mesmo que não ser feliz. A percepção desta relação não implica, de forma alguma, para as entrevistadas que se desconsidere o sintoma sentido ou que ele seja rotulado como "problema psicológico". Independente da relação com o problema doméstico, elas imaginam que a queixa possa ter eventualmente uma reparação nos serviços de saúde, e almejam isto. Nem sempre esta reparação será atingida, embora sempre possa ser antevista. O "nervoso", no caso de Carla e Elza, não é "da mente", mas sim "da infelicidade". Elas querem fazer tudo diferente para seus filhos, porque aspiram, ao menos para eles, a possibilidade de uma vida boa e justa. 
Cláudia e Carla descrevem seus maridos, por sua vez, como doentes mentais. As duas submeteram-se a terapias, aproveitaram a experiência, mas não se consideram "doentes mentais". Já o comportamento de seus maridos, as duas concebem ao menos parcialmente, como doença mental, que também não aparece "nos exames" dos serviços de saúde:

Aí, nessa vez, nessa terapeuta que eu fui a primeira vez, ele andava doido, doido, doido, doido. Nós andava com medo dele matar nós até. Quantos que não matam? Ah..., não tem hora. Aí, eu falei com aquela terapeuta, falei "será que podia pedir um daquele diagnóstico comigo?" O meu saiu tão real. Eu confiei, saiu, eu sei o que saiu pra mim. Aí, pedi. Escondido dele. Eu ainda tinha que arrumar dinheiro pra pagar, não era baratinho. Nem me lembro quanto era, mas não era baratinho, não. Pra mim. Aí, ela deu o dele. Menina, mas saiu tudo, tudo, tudo. Tudo, tudo que ele é. Ele..., ela falou uma porção de coisa dele, por escrito ela dava, coisa mais linda. $E$ saiu assim "que você Júlio, é o que podemos chamar de doente mental". Ele é um doente mental. Só que a doença dele é um tipo de doença que ele é capaz de fazer exame, que não vai acusar. Que tem oscilação. É que nem..., é uma coisa que não tá e tá normal (Cláudia).

A violência cometida pelos maridos agressores é percebida como uma doença em si, provocando sofrimento e doença nos outros. Tendo esta estranha característica de ser uma doença (anormalidade sócio-vital) que não aparece nos exames nem é referendada como patologia (ela oscila), a violência coloca as mulheres na difícil posição de ter que negociar a enunciação do problema como tal. Difícil, porque não encontram nos serviços todo o apoio desejado, nem para elas, nem para seus parceiros, tornando-se aquilo que a psiquiatria tem chamado “pacientes detestáveis" (Senna, 1999). Além do serviço ter dificuldade de encontrar a doença percebida, os parceiros recusam-se a comparecer, dizendo que não são loucos e, portanto, não precisam tratar-se:

Ele vive naquele mundo dele ... bebendo ... bebe na sexta feira, aí no sábado fica o dia inteiro de ressaca ... e assim vai indo. Não procura um médico, que nem eu já vim trazer ele aqui uma vez ... Nossa Senhora ... Eu falei - eu vou levar como quem não quer nada ... -, só que aqui tem entrevista, né, antes ... Ah, na hora que ele saiu aí fora ele já falou um monte...

Trouxe na Saúde Mental ... Daí ele falou assim - é, você me trouxe aqui ... está pensando que eu estou louco igual a você? Louco não estou não, a louca é você ... de ficar agüentando essas baboseiras ... -. Falei - não, Ubiratã., não tem nada a ver ... mesmo você toma calmante, eu não posso ficar pedindo calmante teu assim ... que 
não está certo ... -, ele toma calmante mas não é assim ... foi o médico que receitou, desde a primeira vez, entendeu ... mas eu tenho uma amiga que me arruma as receitas. Então, não acho certo ... como ele bebe ... (...)

Ah, então, como estava falando, que eu trouxe ele aí ... tinha marcado consulta com ele e ele nem voltou, não ... falou que esse era lugar de doido ... que ele não era louco. Falei - Ubiratã, não é só quem é louco que precisa ir fazer psicólogo ... no médico de cabeça, tem muita gente que não tem problema e precisa ... E ele precisaria fazer, entendeu, pelas atitudes dele ... Eu não sei ... e, às vezes, mesmo ele estando sem cerveja ... as reações dele são a mesma coisa. Ele não tem paciência com nada ... mas também tem vez que aí ele está bem ... (Carla).

Note-se o estigma da saúde mental para esta população, que as nossas entrevistadas buscam desfazer, mas em cuja tradição se encontram.

Apesar de perceberem o vínculo entre a vida vivida e os sintomas que sentem, não há sentido para estas mulheres em apresentar o problema de violência que vivem diretamente aos serviços, pois antevêem que a situação assim enunciada não poderá ser acolhida, já que o serviço, de tradição impermeável, só acolhe restritamente as doenças mesmo. Podemos imaginar que percebam também que uma das atitudes do serviço seja justamente encaminhá-las para a Saúde Mental, o que não é exatamente o seu interesse principal, na maior parte das vezes. Perguntadas se explicitam nos serviços as situações de violência, que para elas estão nas raízes de seus problemas de saúde, as mulheres levantam várias dificuldades:

$P$ - E você ia no médico e contava que era por causa disso (a violência)?

Cláudia - Não, não contava. O médico também não ia, ele queria saber...da dor. Eu fui lá, era por causa da dor, não era terapia. Aí falava da dor, o médico dava Voltaren, essas coisas...Tomava infiltração, fazia... exercício de fisioterapia, ultrasom, ondas curtas, enfim. (...)

Eu fui no médico. Fui. Mas eu tinha que ter ido..., naquele tempo não tinha delegacia da mulher, depois teve mas eu não fui. Não fui, imagina. Não ia...

Cheguei falar que era ele e tudo. Falava. Mas, o médico não faz nada. $O$ que vai fazer, é você ir na delegacia e procurar um advogado, de lá... de lá mesmo eles encaminham (Claudia).

A falta de interesse e competência dos profissionais de saúde para lidar com o problema é colocada por esta mulher, já que a vocação dos serviços é percebida 
como outra, tratar doenças, e não acolher problemas das relações interpessoais. A terapia e a DDM, estas sim, seriam mais adequadas, em sua visão, para esta abordagem. Além destas, as barreiras citadas para a expressão direta da violência nos serviços foram a falta de tempo do profissional e vergonha da usuária de revelar sua situação para qualquer pessoa. Note-se que estes obstáculos reforçam a fala profissional, pois reiteram que as mulheres têm mesmo vergonha do problema. Ressaltam também a falta de tempo, que se não foi problema no serviço estudado pela organização do trabalho implantada, parece ser na maioria dos serviços públicos existentes no país. Ou seja, a impotência profissional, a falta de tempo destes e a vergonha de expor o problema são aspectos reforçados pelas usuárias, embora percebam a conexão da situação de vida sobre sua saúde.

Ele me batia, ele me machucava. Quanto soco ele me dava, assim ... doía, porque aqui na gente é muito sensível, nos seios. Mas a pessoa tem uma dor assime a pessoa nem descobre. Por quê? Já apanhou do marido, mas imagina que eu ia falar

Eu nunca falava para o médico, imagina que eu vinha no médico machucada, eu falava para a minha família que eu caí, ou que eu machuquei. (...)

Tem médico que tem pressa, para você contar o que você está sentindo. No $H . U$, o que estou te falando, tem dia que eu chego lá passando mal, assim ... o médico ... você fica lá dois minutos ... se fica dois minutos você fica muito. A não ser que você chega ruim, ou então você tem que chegar lá com alguém e falar assim - fala que você está me levando, me carrega assim, fala que estou passando mal demais que eles ... aí eles vão atender, vão fazer os exames ... -. Mas se chegar assim ... está certo que estou com uma dor aqui ... Um dia cheguei lá chorando de dor assim ... e ele não falou nada, ele olhou para mim, não falou nada, me deu remedinho e pronto. Aí eu fico revoltada, como que o médico não fez nada, nem olhou em mim.

Oh ... você pode marcar, menos de dois minutos. Aí eu vou e não compro o remédio. Aí eu não compro, porque eu falo assim - é um desaforo, não fez nada.

Você no hospital chega morrendo e é atendido na hora. Se você chegar sozinha, conversando, eles não te atendem muito bem, não, mas se você chega assim, morrendo, carregada por alguém falando - não, não pode andar, não pode falar -, aí é atendida na hora lá no hospital, no pronto socorro (Marluce).

Remetido aos serviços de saúde, o sofrimento compreendido como doença deve ser expresso em queixas que buscam legitimar-se na nosologia biomédica e fazer sentido nesta linguagem. Deslocadas da vida privada e de seus conflitos, a 
violência transmuta-se em queixas importantes para as mulheres que as portam, mas que nem sempre correspondem a alterações anatomo-fisiológicas, assim como definidas pelo saber que orienta o trabalho dos profissionais de saúde. Deste deslocamento discursivo nascem conflitos e uma baixa resolutividade dos serviços, resultando em clientes insatisfeitas com a falta de atenção recebida e profissionais exasperados com queixas que não têm resolução dentro do saber que orienta o seu trabalho, formuladas por pacientes que se tornam detestáveis.

Tendo suas demandas sistematicamente recusadas pelos serviços de saúde, Marluce manipula a linguagem médica para se fazer ouvir: pede para as vizinhas a levarem carregada ao hospital, porque sabe que assim será recebida e considerada como um caso importante. Faz, assim, conscientemente, o exagero de sintomas que os profissionais se recusam a acreditar que as mulheres sejam capazes, ao argumentarem pela inconsciência delas. Mas age desta maneira para tentar romper a barreira imposta pelos próprios profissionais à emergência da situação de violência, remetendo o problema para o serviço em sua própria linguagem (da doença). Este efeito, porém, é efêmero: os profissionais, que dominam a linguagem da doença, imediatamente percebem a farsa (do seu ponto de vista) e tenderão a desqualificar ainda mais as queixas, assim que perceberem a falta de substrato anatômico delas. Buscando ser ouvida, Marluce é silenciada, pois o serviço não pode qualificar as demandas que lutam para emergir. Marluce não mente: sente muitas dores, e busca ser escutada para encontrar uma reparação. Nesta busca, apropria-se de uma linguagem que não domina e faz um uso estratégico dela, visando fins específicos em suas relações familiares. Reclama que a doença dela não dá nos exames e procura encontrar o exame que, por fim, dê sentido à sua dor, legitimando-a como doença. Mas há um trágico equivoco, dela e do serviço, que faz com que a estratégia não seja completamente bem sucedida, pela impossibilidade comunicativa estabelecida pela hierarquia dada no discurso dominante que ela pode tentar manipular, mas não domina. A palavra final é do 
médico e, para ele, ela não tem nada, porque não se encontram alterações anatômicas em seu corpo. Marluce desconfia de que falar do problema violência poderia até ser importante: às vezes, o médico não descobre o problema porque a mulher não conta que apanhou. Mas no contexto de atenção que ela descreve (no máximo dois minutos de consulta), a opção de abordar diretamente o problema está descartada de saída.

O problema da vida privada afeta a saúde física e mental e acaba por ser remetido aos serviços de saúde na forma de queixas as mais variadas, que expressam o sofrimento no corpo. As mulheres sabem que têm que encontrar a forma apropriada de ser escutada pelos profissionais de saúde, expressando suas preocupações da vida prática nesta linguagem que lhes é conhecida apenas parcialmente. Para isto, têm de saber discriminar que parte desta experiência pode e deve ser apresentada aos profissionais de saúde. Esta não é sempre uma tarefa fácil, pois é necessário reconhecer no trabalho em saúde possíveis respostas para os problemas apresentados para que a busca de ajuda faça sentido. Carla relata um problema na esfera da sexualidade (falta de prazer com o marido), que acha que pode ter sido originado pelas situações de violência que vive, e que reluta em apresentar ao médico, embora desconfie que eventualmente poderia encontrar algum apoio nesta esfera:

Já tem um tempinho. Inclusive estou para vir aí, ver se eu marco com a médica ... se é falta de hormônio, se é falta de alguma coisa, não sei o que poderia ser... Que alguma coisa devo de ter, não sinto nada, nada, nada ... Se deixar vai semanas e semanas e vai embora ... Se ele me procurar ... e é tão ruim manter relação assim, porque você não está sentindo nada, então tudo se torna horrível ... você não vê a hora de sair de cima, sabe ...

Eu deveria (ir ao médico), eu tenho que fazer isso ...

Não, não acho difícil, não ... acho que ... sei lá eu ... às vezes ele fala que eu procuro muito médico, sabe ... Se eu acho que tem a solução para meu caso, por que não procurar o médico? Pode ser que seja da minha cabeça isso ... ou pode ser que eu esteja precisando de alguma coisa... Estou em torno dos 40 , então pode ser alguma coisa, não sei ...

Então, sei lá eu ... e ... eu sinto que ele está percebendo e eu fico com dó, porque eu acho que não deveria estar fazendo isso. Mas não é de mim ... Se falassem 
que eu sentia prazer por outro homem ... também não, de jeito nenhum. $O$ outro dia eu taquei na cara dele - você é simplesmente o culpado de eu estar assim, de eu não sentir mais prazer, não sentir mais nada, infelizmente é assim -. Já falei para ele vou procurar um médico e vou tomar um remédio, para que me dê vontade de ... já que você quer...

(Acho que isto aconteceu por causa de) muita coisa, muita briga, né ... Mágoa, eu sinto isso. Principalmente quando ele estava bêbado ele falava que eu era prostituta, que dava para todo mundo na rua ... que eu dei para fulano, que eu dei para beltrano, entendeu ... então acho que pode vir a ser tudo isso também, não sei. Porque você acaba guardando, você queira ou não queira, você acaba guardando. Não sou de ficar com raiva de ninguém, mas, não sei ... e acho que foi depois de tudo isso, de começar a falar esse tipo de coisa ...

Nunca dei motivo. Se eu tivesse dado motivo, de ter me pegado com alguém ou fazendo alguma coisa, tudo bem, ele estaria no direito dele, mas ele nunca pegou nada, entendeu.

Acho que eles (os médicos) podem pedir um exame ou alguma coisa ... ou virar para mim e falar - é da sua cabeça ... -, pode até ser ... Eu acho que pode ser da minha cabeça ...

Eu também penso que pode ser algum problema de ... que dizem que problema de hormônio faz também, né ... não sei ...

Só o médico poderá me dizer. Bom, eu fiz exames de sangue, quem sabe ... bom ... não sei ... mas eu acho que é mais da minha cabeça mesmo.

(Carla).

Ela desconfia que o seu problema é ocasionado por muita briga e mágoa com os xingamentos constantes que o marido lhe dirige, mas sabe que só o médico poderá lhe dizer com certeza, ancorado em seu discurso competente, legitimado socialmente, se esta anormalidade é da sua cabeça ou é algum problema de saúde no seu corpo, e qual é o tratamento possível. Se for coisa de sua cabeça, não considera seriamente a possibilidade de um apoio técnico, mas acha que poderia resolver sozinha a questão. Mas talvez exista uma possibilidade de um hormônio eventualmente restituir-lhe a libido. Carla tem dúvidas sobre o que está acontecendo com ela. Estaria ela normal, não sentindo prazer com o seu marido nestas condições?

Carla está perto dos 40 anos e seus problemas são múltiplos. Ela busca uma enunciação para os serviços, que possa ter alguma satisfação antevista e conhecida 
nos serviços de saúde. Hesita em falar da falta de prazer, que acha que pode ser coisa da sua cabeça. Pretende remeter aos serviços diversas queixas que falam de alterações "hormonais", na visão dela, e que lhes parecem mais adequadas, já que não deixam dúvidas quanto à localização orgânica. Ela imagina que os serviços não vão querer ou poder lhe dar um "remédio" para ter prazer, já que esta solução não parece disponível concretamente, embora esteja cada vez mais próxima (é só lembrar da promessa do Viagra, por exemplo, para imaginar que algo semelhante para as mulheres deve ser possível em pouco tempo). Mas poderia usar hormônios para tratar a menopausa, já que estes, sim, são amplamente divulgados e estimulados, e eventualmente resolver desta maneira os problemas na sexualidade. Provavelmente ela apresentará aos serviços as queixas que the parecem mais legítimas e eficazes na relação com o serviço, relacionadas com o seu ciclo menstrual e sua idade, solicitando hormônios. Ao levar a queixa assim "camuflada", ela dificulta sem saber o trabalho profissional e compromete a eficácia possível deste trabalho. Uma parte de suas queixas não tem tradução na linguagem médica e provavelmente será desprezada, ainda que ela busque aproximá-la dos hormônios e do corpo. A conexão que ela mesma faz entre a falta de prazer e as condições da relação, que dá sentido a todo o resto, entretanto, dificilmente encontra espaço de expressão, já que ela tem dúvidas em colocar e o médico tem problemas para perguntar e acolher, uma vez que não pode responder de forma "resolutiva". Quando examinamos o modelo PAISM, notamos que estes canais já são mais abertos em alguns espaços e, algumas vezes, o problema pode expressar-se mais amplamente que o recorte estritamento biomédico ou psicológico, levando à criação de novas possibilidades de trabalho.

As mulheres furtam-se a expor as conexões percebidas entre as queixas e os problemas na vida, porque temem ser desqualificadas em sua demanda e não receber nenhum apoio. Mas o uso que fazem do serviço, apesar de parecer inadequado para os profissionais, faz sentido em suas vidas e tem efeitos, às vezes, 
inusitados e não pensados pelos próprios serviços, que avaliam sua eficácia principalmente pelo diagnóstico e tratamento de doenças.

A doença traz para Marluce, por exemplo, a possibilidade virtual de refazer sua interação com o marido. Ela chega a declarar que fica com ele por isto: ele é muito bom para ela e cuida dela quando ela fica doente.

Eu estou com ele também porque ele é muito bom para mim. Se eu estou doente, ele compra remédios ... O outro dia ele chegou, veio correndo procurar uma farmácia, nem sabia onde estava de plantão, aonde tinha farmácia de plantão, foi procurar. Não me deixa faltar nada, ele me respeita muito ... olha ... não tem um cara que me respeite mais do que ele ... não tem ninguém que me respeite mais do que aquele homem (Marluce).

Quando está doente, o marido de Marluce a trata bem: mesmo se estão brigados, lhe dá a mão para caminhar, compra remédios, é carinhoso. Podemos imaginar, assim, que o uso estratégico do serviço de saúde tem como fim a retomada da interação, agora em outro plano, na vida familiar.

Outra situação encontrada, que pode exemplificar estes efeitos inesperados (para os profissionais) do uso de serviços na vida das usuárias aparece no relato de Claudia:

Então, eu tenho calmante em casa, que a médica... me deu mas eu não posso tomar porque eu sou sensível. Se eu tomar um quartozinho, não posso tomar calmante, eu fico o dia inteiro adormecida, que nem um algodão. Que nem um algodão assim, sabe? Tá bom, está lá em casa, guardadinho. Um dia, eu pensei "quer saber?, esse cara não vai no médico, não se trata, ele derruba tudo na gente...". O dia que ele xingou o meu pai, xingou a minha filha de putedo, essa putaria, putaria; pintou os canecos. Isso aí entra criança, putedo é todo mundo; é criança, é todo mundo. Eu falei "que saber? vou dar um calmantezinho pra esse cara".

Sabe por que, minha filha? Não é pecado, vamos supor, pecado eu sei que não é mesmo, mas... eu não estou cometendo nenhum crime, porque ele não vai ao médico. A sociedade não trata desses caras; o governo, em si, não... não dá... o..., não vê 0 que as famílias passam, o quanto as famílias, eles destroem, essas pessoas assim..., com essas doenças. Então, ele não vai. Se eu for, a lei não está vendo o quanto a minha filha já gastou de terapia, o quanto ela gastou com as crianças, pras crianças saírem de baixo das insultas, das coisas dele. Jura de matar a mãe deles, jura, jurava que ia matar. Você acha, duas crianças ouvindo isso, da mãe? Machuca. É que nem eu falei, isso aí é violência. É uma violência que fica pra sempre. 
Então... então, se eu for... a sociedade não faz nada, não é por mim, não faz por outras pessoas também.

- Então, eu falei "eu não tenho aonde correr". Ele está ficando cada vez mais... a doença... aprimora, não diminui. Eu falei "quer saber? vou dar um calmantezinho pra esse homem". É forte, que é danado. Comecei dando um quarto, de tardinha assim, eu faço chá, um cházinho bem bom pra nós dois, sentamos lá no sofá "ó, o chá", eu falo "ó, o chá". Pego desmancho bem o danado, aquilo é duro, desmancho bem Jesus amado, misturo com açúcar, faço um pózinho, ponho no chá. Dou a colher pra ele, que ele ainda vai mexendo pra tomar. Não pode dar muito, que desconfia..., desconfia. (Claudia)

Não encontrando apoio social nenhum, Claudia toma uma medida por sua própria conta. Esta estratégia não reata a comunicação mais livre com o parceiro, mas, pela manipulação dele busca colocá-la em menor risco. O serviço de saúde tem, assim, o seu trabalho modificado, e serve a fins bem diversos de seu propósito inicial. Do ponto de vista de Claudia, o calmante que lhe prescreveram foi muito bem aproveitado. Do ponto de vista do serviço, obviamente o uso foi totalmente ineficaz e distorcido. É importante lembrar que estas pacientes têm um maior risco de receber antidepressivos e ansiolíticos, que podem ser utilizados de forma totalmente não previstas, tanto em tentativas de suicídio, para as quais têm um maior risco, como em alternativas mais "criativas", como a apresentada. A prescrição destas medicações deveria, portanto, ser bastante criteriosa e, mais do que isto, negociado.

Outro exemplo de uso "não institucional" das instituições disponíveis é o que Marluce faz da DDM. Como Cláudia, ela usa a instituição para melhorar sua situação na relação com o parceiro. A diferença é que Marluce explicita seu objetivo para o marido, usando a DDM como uma "arma" na negociação. Ouçamos o seu relato:

Porque ele ficava assim - ah, eu posso usar a arma ... -, não sei o que ... e aí um dia ele brigou mais eu, aí eu queria porque queria tirar aquele revólver dele, com medo dele me dar um tiro, mas ele nunca me ameaçou, nunca falou - vou te dar um tiro, nunca -, ele falava que ele podia usar, eu falava - pára de usar isso na cintura, 
que perigo -, - ah, eu tenho porte -, isso quando bebia, né, - eu posso usar, que eu tenho porte de armas. Aí minha filha, eu falei que esse cara ia me pagar, que não ia ficar por isso, não, - eu vou ter que tomar, porque um dia que a gente brigar ele vai me dar um tiro -, aí fui na delegacia e falei que ele estava me ameaçando, e ele não estava. Falei mentira, coitado. Aí depois eu falei com o delegado - é que eu estou com medo, que eu tenho um filho pequeno, e ele bebe -, eu expliquei, - o senhor está sabendo que eu tenho B.O aqui, que a gente vive brigando, eu tenho medo de numa hora ele estar nervoso e puxar a arma, dar um tiro e matar até a criança também-. Aí tomaram, prenderam a arma dele. O delegado falou assim-mas eu não posso prender a arma dele, ele tem autorização para usar arma -, para usar sim, na cintura, andar com ela na cintura.

De tanto que eu fiz, falei para o delegado - eu não vou sair daqui, vou ficar aqui -, eu fiquei na delegacia com meu filho - se o senhor não for lá ver essa arma eu não vou voltar para casa -. Eu catei a arma assim enroladinha e levei ... aí ele falou assim - então tá, então vou prender a arma, só tem uma coisa, se eu prender essa arma aqui ninguém mais tira, só a senhora pode tirar -. Aí ... no outro dia falei - não falei para você que eu ia mandar ela prender?, você fica xingando, eu tenho medo de você pegar essa arma e atirar. Cadê minha arma? , - está na delegacia. -Você está brincando. - Está... . - Aí estava pagando advogado, pagando advogado e nada. Aí eu sou tão ruim, sabe o que eu falei - eu te dou essa arma de volta, eu vou lá e tiro, mas se você fizer uma declaração dizendo - eu, Fulano, prometo nunca mais bater na minha mulher nem ofendê-la com palavras imorais ..." Aí quando eu vou lá o cara fala - é a primeira pessoa na vida que eu vejo mandar o marido falar uma coisa dessas e fazer - ainda falavam - viu machão ... -, falavam assim para ele, na cara dele ... que esse pessoal é aqui na Delegacia da Mulher. Aí ele falou assim - você tem certeza, dona, que a senhora quer tirar? -, eu falei - tenho, eu já mandei fazer isso -, e ele dava risada olhando - nossa.

Ele assinou ... mandei fazer assim, eu falando e ele escrevendo com a letra dele ... - eu ... Fulano marido de fulana de tal ... prometo nunca mais bater nela, nem ofender com palavras imorais, para tirar a minha arma -. Tirou, e aí o medo que eu tinha ... aí outro medo. Aí chegou em casa, eu falei - o que você vai fazer com essa arma? -, porque ele falou para mim que ia vender, que se eu tirasse ele ia vender para não perder, para recuperar um pouco do dinheiro. Eu falei - tudo bem ... -, aí ele foi e vendeu mesmo.

Note-se que Marluce fez com a lei o mesmo que faz com a medicina, quando pede para ser carregada para ser atendida no hospital: para ser ouvida, precisou usar da linguagem do crime, e inventar que o marido a ameaçava para justificar sua queixa à DDM e a retirada da arma de fogo da casa.

O uso da Delegacia foi bastante comum. Apenas Claudia e Rosana não o relataram. Entretanto, apenas Marluce contou uma situação em que a instituição 
foi completamente resolutiva, do seu ponto de vista. As outras duas relatam um uso que consta basicamente de fazer a queixa e arquivá-la. Pensam, assim, que em caso de necessidade podem abrir de novo a "queixa" arquivada e usam este argumento na negociação com o marido. Desta forma, a queixa parece cumprir o propósito colocado por elas ao enunciá-la.

O que acontece na assistência à saúde ou mesmo na Delegacia de Polícia é apropriado pelas mulheres em lógicas, muitas vezes, não perceptíveis para estas instituições. No exemplo a seguir, Marluce busca argumentos na consulta para convencer o marido a procurá-la mais vezes sexualmente, problema que deflagra uma boa parte de suas brigas com o marido. Recorre à palavra da médica, que lhe responde a uma questão sem saber sua real intenção. Marluce conta o seu problema, mas diz que é de uma amiga sua. Depois, aumenta um pouco a resposta recebida para negociar a sexualidade com o marido:

Ah, uma vez fui no médico, uma médica, ah ... faz muito tempo. Era uma médica, contei para ela, aí estava com vergonha de falar, aí falei para ela assim ... não contava muito as coisas da minha vida, tinha vergonha. Aí eu falei para ela, que se demorava (para ter relação sexual) se fazia mal, porque eu tinha visto isso na reportagem ... não sei o que ... E ela falou que fazia, sim. Aí eu cheguei em casa e fui contar para ele, para que ... ele falou - que nada!, você sai daqui para contar da sua vida para os outros!, você é boba ... como é que ela quer saber da sua vida? -, eu falei - quer sim, ela falou que quer saber sim, que se interessa, porque ela mexe com isso e ela quer saber. Isso faz muito mal, tá, é por isso que eu estou passando mal, é por causa disso -. Aí eu menti o que a médica falou, mentira pura.

Falei que tinha que fazer pelo menos umas três vezes por semana. Ele falou - duvido que o cara tenha tanta .? para fazer ... -, eu falei - então você está mal -, falei assim. Ah, meu Deus do céu ...

É interessante que a opinião profissional seja chamada aqui para resolver um conflito doméstico que não foi explicitado. Marluce não foi clara com a profissional e manipulou sua fala para conseguir os fins desejados na relação, mas o serviço ficou totalmente inconsciente disto.

Será que então o medo de alguns profissionais acerca de interferir na vida pessoal das usuárias não deveria ser repensado? Marluce argumenta que a médica 
se interessa por sua vida porque mexe com isto... Será que o que precisamos não é justamente perceber que intromissão é esta e torná-la mais dialogada e respeitosa de ambas as partes, resgatando uma relação Eu-Tu anterior à inevitável e necessária Eu-Isso da prática profissional?

Como resgatar a interação comunicacional no trabalho? Imaginamos que o estudo do problema violência possa nos trazer luzes sobre esta tarefa tão importante para a qualidade das práticas e das relações humanas. 


\section{Considerações finais}

Tratamos aqui das possibilidades e limites para a emergência (enunciação e escuta), acolhimento (continência e qualificação da demanda) e resposta ao problema da violência contra a mulher em serviços de saúde. Tomamos para estudo um centro de saúde escola (CSE) que tem ações do PAISM implantadas e avaliadas.

Ao analisarmos o funcionamento prático, a operacionalização deste modelo, percebemos suas tensões em relação ao modelo hegemônico em saúde por meio dos diferentes desempenhos de seus profissionais e de diferentes expectativas, usos de serviço e resultados alcançados pelas mulheres em relação a este e a outros serviços, que configuram formas diversas de acolhimento e resposta ao problema.

Portanto, mais do que se a violência emerge ou não e em que quantidade, interessou-nos saber como isto acontece; que sentidos adquire para profissionais e usuárias; e qual poderia ser o seu lugar no cuidado efetuado. Nossa motivação principal foi conhecer mais o problema para dar subsídios à construção de alternativas tecnológicas próprias para a incorporação do tema na prática em saúde.

Percebemos que o modelo "PAISM" implantado foi introjetado pelos funcionários e mesmo pela população e criou canais que propiciaram a emergência de muitos relatos sobre direitos reprodutivos, que foram incorporados ao trabalho, não sem conflitos. As situações de violência também emergiram no interior dos diversos canais de comunicação criados no trabalho. $\mathrm{O}$ acolhimento e respostas destas situações, entretanto, são menos consensuais que as ações já efetuadas para os direitos reprodutivos, já que não possuem projeto de trabalho acordado entre os profissionais. 
Mesmo quando a violência é escutada, portanto, ela não necessariamente é acolhida.

Uma primeira resposta possível, quando estas questões são colocadas para os profissionais, é ela não ser escutada e apenas a "queixa" de possível doença ser aceita. Nestes casos, podem ser prescritos exames ou tratamentos no sentido de satisfazer a mulher (ou o profissional, que se livra da demanda inconveniente), mesmo quando a indicação técnica é bastante imprecisa. Trata-se de medicalização, o momento quando a linguagem competente obstrui o juízo prático sobre as coisas do mundo da vida no interior do serviço e reitera a busca incessante de uma resposta técnica.

A segunda resposta possível foi a mais encontrada em nossa observação. Quando o problema é enunciado, ele pode ser escutado e qualificado basicamente como sofrimento mental, o que não satisfaz a muitas das usuárias. Aqui também os diagnósticos são geralmente vagos, no limite entre o sofrimento humano "normal" e a patologia. Chamamos este processo de psicologização/psiquiatrização, para chamar a atenção de que ele é a medicalização do "mental": chama-se aos cuidados técnicos sofrimentos que não necessariamente estão sendo colocados para serem resolvidos neste plano, ampliando os setores da vida sob esta jurisdição técnica.

Por último, há ainda uma outra possibilidade de trabalhar o problema. Esta é concebê-lo não como patologia física ou mental, mas como problema social, e abordá-lo pela comunicação. A atenção primária, por ser a porta de entrada do sistema de saúde, tem em nosso entendimento o papel mesmo de acolher diversas demandas sociais e queixas que não se enquadram como patologias, porque tem como tarefa buscar garantir e promover a saúde. Mas, como trabalhá-las?

Em primeiro lugar, facilitando sua emergência. Para isto, é necessária a criação de espaços de expressão e escuta de problemas práticos, incorporando esta dimensão ao trabalho e transformando radicalmente o papel dos serviços de saúde, 
ao menos na atenção primária: de um local que puramente diagnostica e trata patologias para um lugar em que se cuida da saúde das pessoas, e o diagnóstico e tratamento de patologias está subsumido a esta finalidade maior.

Enfim, trabalhar questões do tipo da violência e não medicalizá-las ou impor a autoridade moral do profissional como correlato natural de sua superioridade técnica exige uma mudança de organização de serviços e de desempenho profissional. Além de se valer de seus conhecimentos técnicos, os profissionais devem valer-se, conscientemente, de suas opções éticas, para, genuinamente, colocá-las em confronto e debate cotidiano na ação profissional. Só assim, buscando uma maior simetria na comunicação e a abertura de canais de comunicação livre, é possível e desejável trabalhar este tipo de problema nos serviços de saúde.

A ação comunicativa revela assim o seu conteúdo propriamente tecnológico, ao articular-se com a ação estratégica em posição de superioridade quando a questão está, como no caso da violência, nas relações sociais e não estritamente no corpo. Não se trata, aqui, apenas de valorizar a "conversa" como um acessório importante, em termos de educação e bons tratos, nem restritamente a tematização da clássica "relação médico-paciente". Trata-se, sim, de assumir e tematizar as questões éticas presentes para o trabalho em saúde, mesmo naquele que se diz completamente "neutro", apenas "técnico", e da necessidade de se buscar a fala mais genuína de ambas as partes. Quando no plano da atenção primária, esta necessidade torna-se ainda mais dramática. Isto exige dos profissionais que abandonem a fria e falsa neutralidade da ação "puramente" técnica e passem a um verdadeiro encontro com o outro. É neste encontro Eu-Tu que pode haver o crescimento de ambos, e uma maior potencialidade resolutiva, por fim, dos serviços de saúde. 
Devemos todo o tempo lembrar que a violência, como vimos, "é" e "não é" problema dos serviços de saúde. É, porque está associada a patologias e maior uso de serviços, e porque está presente na vida ruim e injusta que é a própria falta de saúde. Mas não é, porque o problema da violência não começa nem se esgota na saúde, e tem determinações muito mais amplas. As soluções propostas para o problema abrangem ações de diversas áreas.

Por isto, o trabalho em saúde deve ser necessariamente intersetorial, articulando-se com instituições e movimentos sociais para o trabalho com o tema, já que a "solução" aqui pode muitas vezes ser um bom encaminhamento que atenda às expectativas da usuária. No interior do serviço, o trabalho precisa ser multiprofissional, lançando mão de vários profissionais diferentes (psicólogo, assistente social, médico, enfermeiro), com escutas e possibilidades de intervenção diversas. Por outro lado, é importante haver núcleos comuns de trabalho que sejam compartilhados e realizados por todos os profissionais (a emergência, por exemplo). Não é necessário, obviamente, que todos os profissionais estejam igualmente capacitados para o acolhimento e resposta em qualquer nível de atenção, mas é fundamental que todos estejam dispostos a abrir canais de escuta. Após a escuta, a mulher pode ser eventualmente encaminhada para um profissional ou espaço mais adequado para o aprofundamento da discussão.

Mas como articular esta rede intersetorial e multiprofissional para cada usuária? Qual a "padronização" possível em ações desta natureza? A organização concreta do trabalho dependerá de cada serviço em particular, mas ouvir a mulher e discutir com ela seu problema e disponibilizar informação pode aqui ser uma proposta tecnológica. Note-se que, desta forma, modificamos o tradicional significado de "resposta" como terapêutica resolutiva prescrita unilateralmente pelos técnicos. Qualquer resposta deste tipo em tema delicado como a violência é transposição de autoridade técnica para autoridade moral, normatização da vida privada pelos técnicos, e deve ser evitada se quisermos um modelo do tipo 
proposto pelo PAISM. A resposta que estamos propondo aqui é sempre parcial, e depende da interação que puder ser estabelecida e sobre o que venha a ser, para ela, vida boa e justa. Apoiar este caminho é não só importante para os serviços em termos de uma maior eficácia nas ações como, principalmente, é um dever ético e político para os profissionais que se pensam "da saúde". 


\section{Anexos}

\section{Anexo1}

\section{ROTEIRO PARA OBSERVAÇÃO DAS ATIVIDADES DO PAISM NO CSEB}

Atividades individuais

- Certificar-se de que o gravador e a fita funcionam, testando antes. Dizer a data, seu nome, tipo de atividade observada e o nome de quem é observado como introdução à gravação.

- Anotar na fita e na caixa da fita a data, tipo de atividade e o observador.

- Apresentar-se no início da atividade, lembrando que este é um CS Escola, que faz ensino e pesquisa. Explicar que participa de uma pesquisa sobre as demandas das mulheres à UBS e que vai gravar a atividade, garantindo sigilo absoluto, e solicitando a permissão das mulheres presentes.

- Observar a consulta sem intervir, mas participando se solicitado e esclarecendo dúvidas do discurso se for o caso. Quando alguma informação pertinente parecer confusa ou incompleta, intervir com frases como: explique melhor, ou como assim?

\section{Relatório}

- No início do relatório, escrever o nome da atividade, data da observação, número do prontuário da mulher observada e profissional observado.

- Anotar, antes, durante e depois do atendimento tudo aquilo que parecer relevante, especialmente gestos, expressões, sensações, imagens observadas, características dos personagens das cenas observadas.

- Anexar, ao final do relatório, um parecer pessoal, com opiniões sobre o que achou do atendimento, temas discutidos, situações que propiciaram ou impediram a emergência de temas relativos à violência e o que mais parecer importante.

- As fitas serão transcritas e anexadas a este relatório. 


\section{ROTEIRO PARA OBSERVAÇÃO DAS ATIVIDADES DO PAISM NO CSEB}

Atividades de grupo

- Certificar-se de que o gravador e a fita funcionam, testando antes. Dizer a data, seu nome, tipo de atividade observada e o nome de quem observa como introdução à gravação.

- Anotar na fita e na caixa da fita a data, tipo de grupo e o observador.

- Apresentar-se no início da atividade, lembrando que este é um CS Escola, que faz ensino e pesquisa. Explicar que participa de uma pesquisa sobre as demandas das mulheres à UBS e que vai gravar a atividade, garantindo sigilo absoluto, e solicitando a permissão das mulheres presentes.

- Observar o grupo sem intervir, fazendo, se necessário, intervenções para o esclarecimento de pontos obscuros, do tipo: como assim, explique melhor, o que voce acha disto.

\section{Relatório}

- No início do grupo, fazer um desenho do grupo com a localização do profissional da instituição, pesquisadora e pacientes, anotando para essas o número correspondente ao de matrícula registrado no cabeçalho da folha de relatório.

- Anotar, durante o grupo, os temas discutidos e principais falas relativas a cada um deles, com ênfase no que parecer violência.

- Anotar, sempre que possível, a autoria das falas ao lado, usando o seguinte critério: $\mathrm{P}$ para pesquisadora, E para enfermagem, e 1,2,3,4 etc. para as mulheres usuárias do serviço. Quando não for possível identificar a emissora da fala, colocar simplesmente $\mathrm{M}$.

- Após o grupo, escutar novamente a fita e refazer o relatório, complementando-o. As frases que forem registradas devem corresponder fielmente ao original.

- Anexar, ao final do relatório, um parecer pessoal, com opiniões sobre o que achou do grupo, temas discutidos, situações que propiciaram ou impediram a emergência de temas relativos à violência e o que mais parecer importante. 


\section{ANEXO 2}

Consentimento Informado

Eu, abaixo assinado, concordo em conceder uma entrevista gravada de história de vida à pesquisadora Ana Flávia P. Lucas d'Oliveira. Entendo que esta entrevista comporá seu material para a tese de doutorado "violência de gênero, necessidades de saúde e uso de serviços em atenção primária".

Entendo também que a pesquisadora se compromete em manter total sigilo sobre minha identidade no uso das informações desta entrevista, alterando meu nome e demais dados que possam eventualmente possibilitar minha identificação, e também estou ciente de que as informações por mim concedidas não serão usadas de nenhuma forma que possa prejudicar minha pessoa e minha família.

São Paulo, _ de de 1997

Nome

Assinatura

Assinatura da pesquisadora 


\section{Anexo 3}

Roteiro para entrevista de história de vida

Pontos a serem abordados. O entrevistador deve sempre ressaltar a dimensão de gênero, conduzindo assim a entrevista. Buscar descrição, opiniões, discriminação e exame em detalhe de valores, estimulação de casos, ditos populares e exemplos:

- os pais

- A infância (especificar quando percebeu ser menina- sentimentos e lembranças em relação a isto)

- A primeira menstruação

Os namoros

-Sexualidade

- Casamento

- Gestações, partos e abortos

- O trabalho - doméstico e fora de casa

- Divisão do dinheiro

- Criação dos filhos (atenção para diferenças de meninos e meninas)

- Uso de serviços de saúde - quando precisou, como foi a experiência, em geral e em relação a aspectos especificamente femininos. O que acha que causou seus problemas de saúde, e o que acha que melhorou.

- Considera que sofreu violência durante a vida? Quais?

- O que você acha que é violência, e porquê? Como definiria para seus filhos? O que recomendaria como proteção.

- Alguns destes episódios resultaram em dano para sua saúde?

- Algum destes episódios resultou em busca dos serviços de saúde? 


\section{Anexo 4}

Roteiro para entrevistas com os profissionais de saúde

Estamos pesquisando os significados do uso de serviços de saúde para mulheres que vivem em situação de violência doméstica. Para isto, queremos saber também a percepção dos profissionais de saúde.

1.Você acha que este é um tema comum para as mulheres que você atende? (independente de trazerem ou não como questão).

2.Este tema aparece para você no atendimento?

Em que situações? O que facilita o aparecimento?

O que dificulta o aparecimento?

Conte um caso. O que você faz quando aparece?

3.Você acha que estes problemas têm relação com as questões de saúde e uso de serviços das mulheres? Quais as relações que você estabeleceria?

4.Em uma pesquisa realizada com profissionais de saúde, foram levantados alguns obstáculos ao trabalho com a questão. Se ainda não foram abordados pelo entrevistado, pergunte a sua opinião acerca deles:

muito perto para confortar;

medo de ofender a cliente se perguntar;

impotência para resolver;

perda do controle (a mulher é que tem que fazer algo);

tirania da agenda (falta de tempo, medo de destampar a Caixa de Pandora).

5. Qual você acha que deveria ser o papel dos SS nestes casos? Você tem algum comentário a este respeito? 
Anexo 5

Prontuários com algum registro de violência física e sexual

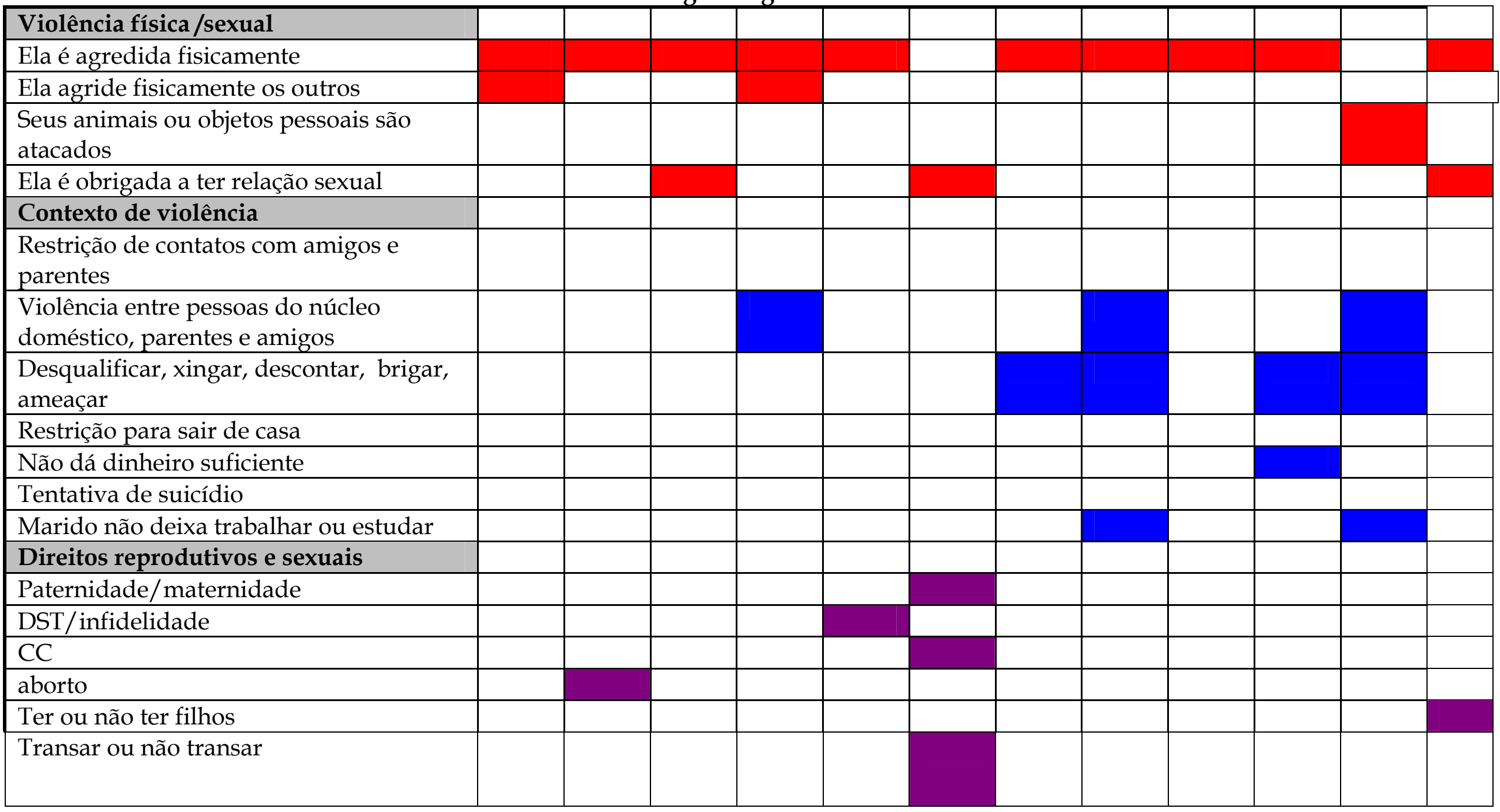




\begin{tabular}{|l|l|l|l|l|l|l|l|l|}
\hline Violência física/sexual & A & B & C & D & E & F & G & H \\
\hline Ela é agredida fisicamente & & & & & & & & \\
\hline Ela agride fisicamente os outros & & & & & & & & \\
\hline Seus animais ou objetos pessoais são atacados & & & & & & & & \\
\hline Ela é obrigada a ter relação sexual & & & & & & & & \\
\hline Contexto de violência & & & & & & & & \\
\hline Restrição de contatos com amigos e parentes & & & & & & & & \\
\hline $\begin{array}{l}\text { Violência entre pessoas do núcleo doméstico, } \\
\text { parentes e amigos }\end{array}$ & & & & & & & & \\
\hline $\begin{array}{l}\text { Desqualificar, xingar, descontar, brigar, } \\
\text { ameaçar }\end{array}$ & & & & & & & & \\
\hline Restrição para sair de casa & & & & & & & & \\
\hline Não dá dinheiro suficiente & & & & & & & & \\
\hline Tentativa de suicídio & & & & & & & & \\
\hline Marido não deixa trabalhar ou estudar & & & & & & & & \\
\hline Direitos reprodutivos e sexuais & & & & & & & & \\
\hline Paternidade/maternidade & & & & & & & & \\
\hline DST/infidelidade & & & & & & & & \\
\hline Ter ou não ter filhos & & & & & & & & \\
\hline aborto & & & & & & & \\
\hline Transar ou não transar & & & & & & \\
\hline
\end{tabular}

Prontuários sem violência mas com pelo menos um registro de contexto

Nestas três tabelas
estão $\quad$ representados
todos os prontuários que
apresentaram algum
registro

$\mathrm{Na}$ primeira, estão aqueles que tiveram ao menos um registro de violência física/sexual; na segunda, ao menos algum com contexto de violência; e na última, os que tiveram apenas registros de questões acerca dos direitos reprodutivos. 


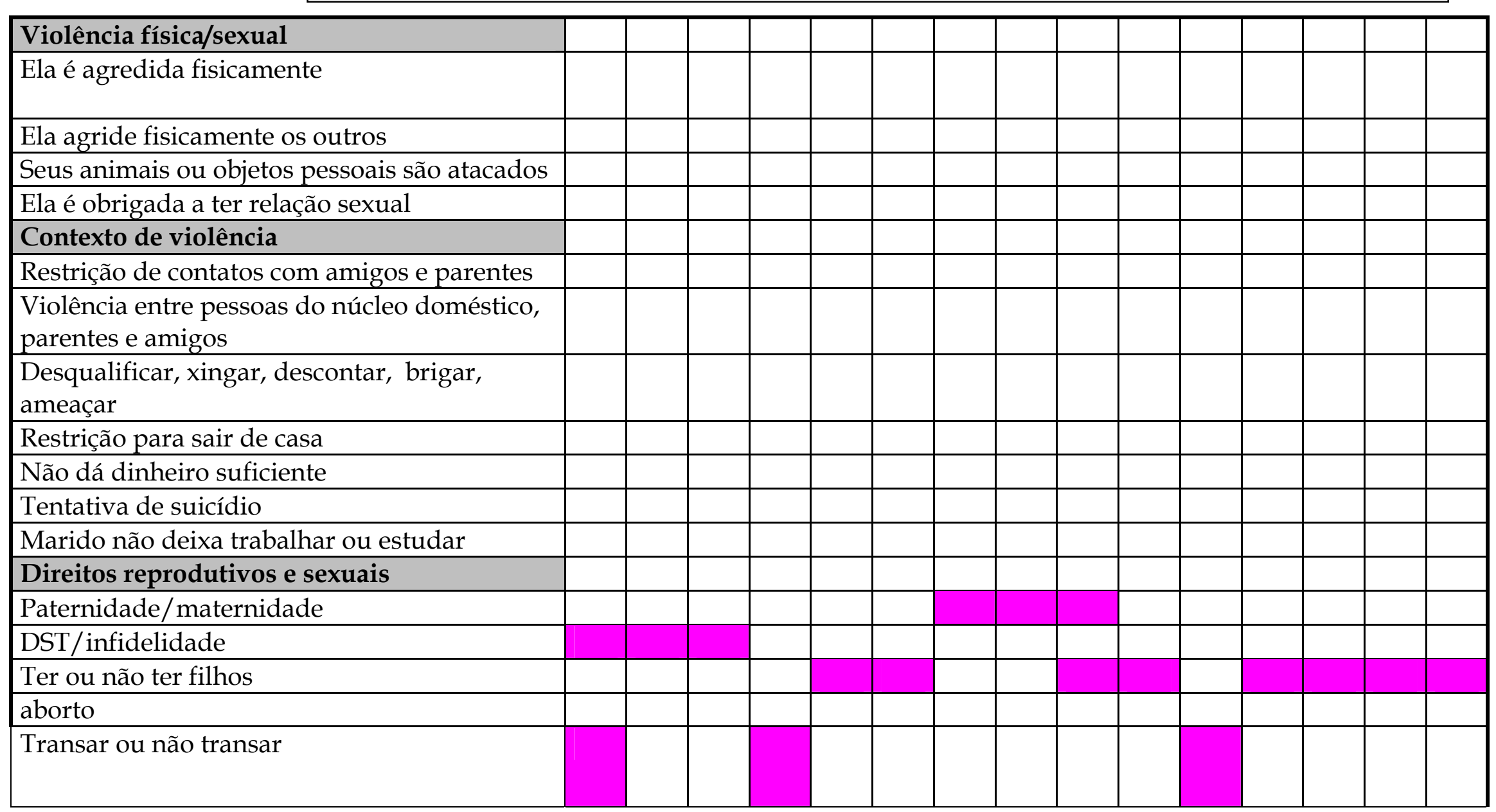




\section{Referências Bibliográficas}

AYRES, J.R. Sobre o risco - Para compreender a epidemiologia. São Paulo, Hucitec, 1997.

ABBASI, K. Obstetricians must ask about domestic violence. BMJ, 316-7 (3 January) 1998.

ALPERT, E. J. Violence in Intimate Relationships and the Practicing Internist: New “Disease" or New Agenda? Annals of Internal Medicine, 123 (10):774-781, November, 1995.

AMERICAN MEDICAL ASSOCIATION. Diagnostic and guidelines on domestic violence. AMA, Chicago, 1992.

ARENDT, H. Sobre a Violência. Rio de Janeiro, Relume-Dumará, 1994.

ARENDT, H. A Condição Humana. Rio de Janeiro, Forense Universitária, 1995.

AUSTIN, J.L. Quando dizer é fazer. PortoAlegre, Artes Médicas, 1990.

AZEVEDO,M.A.; GUERRA, V.N.A (edts.) Crianças Vitimizadas: A Síndrome Do Pequeno Poder. São Paulo, Iglú Editora, 1989.

BEAUVOIR, S. O Segundo Sexo. São Paulo, Difusão Européia do Livro, 1970.

BENFAM Envolvimento do homem em assuntos de sexualidade e saúde. Informe mensal BENFAM, Rio de Janeiro, outubro de 1998.

BOSI, E. Memória e Sociedade. Lembrança de velhos. São Paulo, T. A. Queiroz Ed, 1983. 
BOURDIEU, P. A dominação masculina. Educação e Realidade, 20 (2): 133-184, 1995.

BRANDÃO, E.R. Nos corredores de uma Delegacia da Mulher: um estudo etnográfico sobre as mulheres e a violência conjugal. Dissertação de mestrado. Instituto de Medicina Social, UERJ, 1996.

BUBBER, M. Eu e Tu. São Paulo, Editora Moraes, s/data.

BURTON, N. Resistance to prevention: reconsidering feminist antiviolence rhetoric. In: Freench, S.G.; Teays, W; Purdy, L. Violence against womenphilosophical perspectives. Ithaca and London, Cornell University press, 1998.

BUTLER, B. Variações sobre sexo e gênero. Beauvoir, Wittig e Foulcault. In: Benhabib, S; Cornell, D. Feminismo como crítica da modernidade. Rio de Janeiro, Rosa dos Tempos, 1987, p. 139-154.

CAMPBELL, J. C. Wife- battering: cultural contexts versus western social sciences. In: Counts, Brown; Campbell. Sanctions \& Sanctuary- Cultural perspectives on the beating of wives. Westview Press, 1992.

CAMPBELL, J. C. Violence Research: an overview. Scholarly Inquiry for Nursing Practice: An International Journal, Vol 9 n. 2, 1995: 105-127.

CANGUILHEM, G. O normal e o patológico. 2. Ed. Rio de Janeiro, Forense Universitária, 1992.

CHAUÍ, M. O que é ideologia. Coleção primeiros passos, 13. São Paulo, Brasiliense, 1983.

CHAUÍ, M. Participando do Debate sobre Mulher e Violência. In: Perspectivas Antropológicas da Mulher 4, Rio de Janeiro, Zahar, 1984. 
CHAUÍ, M. Cultura e Democracia. São Paulo, Cortez Editora, 1993.

CHAUÍ, M. Ética e violência. Teoria em debate 39, out/nov/dez 98. 32-41.

CLADEM/CRLP. Silencio y complicidad Violência contra las mujeres en los servicios publicos en el Perú. Lima, 1998.

CORREAA, S.; PETCHESKY, R. Reproductive and sexual rights: a feminist perspective. In: Sen, G.; Germain, A.; Chen, L. C. Population politics reconsidered - Health, empowerment, and rights. Boston, Harvard University Press, 1994, p. 107-26.

COSTA, A.M. PAISM: Uma política de assistência integral à saúde da mulher a ser resgatada. Comissão de Cidadania e Reprodução, São Paulo, 1992.

COSTA, J.F Ordem médica e norma familiar. Rio de Janeiro, Graal, 1979.

COSTA A M. Desenvolvimento e implantação do PAISM no Brasil. In: Giffin, K.; Costa, S. Questões de Saúde Reprodutiva. Rio de Janeiro, ENSP-FIOCRUZ, 1999

COUNCIL ON SCIENTIFIC AFFAIRS - AMERICAN MEDICAL ASSOCIATION. Violence Against Women - Relevance for Medical Practitioners JAMA, 2677 23. 1992:3184-3193.

D'OLIVEIRA A. F. P. L. Gênero e Violência nas Práticas de Saúde: contribuição ao estudo da atenção integral à saúde da mulher. Dissertação de Mestrado. São Paulo, Faculdade de Medicina da USP,1996.

D'OLIVEIRA, A F P L ; SCHRAIBER, L B Violence against women: a physician's concern? In Ottesen, B.; Tabor, A. (Eds) New Insights in GYNECOLOGY \& OBSTETRICS. Research and Practice, Londres, The Parthenon Publishing Group, 1998, pp. 157-163. 
D'OLIVEIRA, A.F.P.L.; LUIZ,O.C.; SORRENTINO, S. (Org) Coletânea de textos para o Curso de Capacitação para Atendimento a Mulheres em Situação de Violência. São Paulo, Departamento de Medicina Preventiva FMUSP/Coletivo Feminista Sexualidade e Saúde, 1995.

D'OLIVEIRA, A.F.P.L., SCHRAIBER, L. B. Violência de gênero, Saúde Reprodutiva e Serviços, In: Giffin, K.; Costa, S. - Questões de Saúde Reprodutiva. Rio de Janeiro, ENSP-FIOCRUZ, 1999.

D'OLIVEIRA, A.F.P.L., SENNA, D.M. Saúde da mulher Em: Schraiber, L. B., Nemes, M. I. B., Mendes-Gonçalves, R.B.(orgs) Saúde do Adulto: programas e ações em unidades básicas, São Paulo, Faculdade de Medicina da Universidade de São Paulo, Hucitec, 1996.

DEARWATER, S.R., COBEN, J.H.; CAMPELL, J.C.; NAH,G; GLASS, N; MCLOUGHLIN; BEHERNEIER, B. Prevalence of intimate partner abuse in women treated at community hospital emergency departments. JAMA, 280 (5) 1998:433-438

DENZIN, N. K.; LINCOLN, Y.S. Introduction: Entering the field of qualitative research. In: Denzin, N.K.; Lincoln, Y.S. (eds) Hanbook of qualitative research, Califórnia, Sage Publications, 1994:1-18.

DINIZ, S. G. Assistência ao parto e relações de gênero: elementos para uma releitura médico-social. Dissertação de mestrado. São Paulo, Faculdade de Medicina da USP, 1996

DINIZ, S. G.; D'OLIVEIRA, AFPL. Gender violence and reproductive health. International Journal of Gynecology \& Obstetrics, 63, suppl. 1 1998:533:542. 
DOMENACH, J.M. La violencia In: La violência y sus causas. Paris, UNESCO, 1981.

DONNANGELO, M.C.F.; PEREIRA L. Saúde e Sociedade. 2. Ed. São Paulo, Duas Cidades, 1979.

DROSSMAN, A. D, TALEY, N.J.; LESERMAN, J.; OLDEN, K.W; BARREIRO, M.A. Sexual and Physical Abuse and Gastrointestinal llness Annals of Internal Medicine, 123(10):782-794, November, 1995.

DUARTE, L.F.D. Da vida nervosa nas classes trabalhadoras urbanas. Rio de Janeiro, Zahar/CNPq, 1986.

EDLESON, J.L.; EISIKOVITS, Z.C. (eds) Future interventions with battered women and their families. Thousand Oaks/London/New Delhi, SAGE, 1996.

EISENSTAT,A S. ; BANCROFT, B.A Domestic Violence . New England Journal of Medicine. 16, September, 1999 886-892.

ELLSBERG, M.; HEISE, L.; SCHRADER, E. Researching violence against womenA practical guide for researchers and advocates. Center for Health and Gender Equity/OMS, 1999.

EILSBERG, M.; PEÑA, R.; HERRERA., A; LILJESTRAND, J.; WINKVIST, A. Confites en el infierno - prevalencia y caracteristicas de la violencia conyugal hacia las mujeres en Nicaragua. Red Nacional de mujeres contra la violencia, Nicaragua/Departamento de Medicina Preventiva y salud publica, UNAN-Leon/Departamento de Epidemiologia y salud publica, Umea Universty, Suecia, Nicaragua, 1998. 
ENKIN. M. KEIRSE, J. N. C., RENEREW, M.; NEILSON, J. A Guide to effective care in pregnancy and childbirth. Oxford/Bew York/Tokio/Toronto, Oxford University Press, 1995.

FIBGE - Participação Político-Social - Justiça e Vitimização v.1 1988 - Rio de Janeiro, FIBGE, 1990.

FOUCAULT, M. História da sexualidade I. Ed. Rio de Janeiro, Graal, 1993.

FOUCAULT, M. Microfísica do poder. Rio de Janeiro, Ed. Graal, 1984.

FREIDSON, E. La profesión médica. Um estudio de sociologia del conocimento aplicado. Barcelona, Edicions 62, 1978.

GALLO, E. (Org). Razão e Planejamento: reflexões sobre política, estratégia e liberdade. São Paulo: Hucitec-Abrasco, 1995, p. 117-154.

GAZMARARIAN, J.A.; LAZORICK S.; ALISON M.SPITZ; BALLARD, T.J.; SALTZMAN, L.E.; MARKS, J.S Prevalence of Violence Against Pregnant Women JAMA, (June) vol 275, no24, .1996 pp.1915-1920.

GEERTZ, G. A Interpretação das Culturas. Rio de Janeiro, Guanabara/Koogan, 1989.

GELLES, R.; CORNELL, C. Intimate violence in families. Beverly Hills, CA, Sage, 1985.

GIELEN,C.A.; O'CAMPOP.J.; FADEN,R.R.;KASS,N.E.; XUE, X. Interpersonal conflict and physical violence during the childbearing year Soc. Sci. Med. Vol.39, n6, .1994 pp.781-787.

GLANDER, S.S.; MOORE, M.L.; MICIELUTTE, R.; PARONS, L.H. The prevalence of domestic violence among women seeking abortion. Obstetrics and Gynecology vol1 n4 1998:1002-1006. 
GOLDEMBERG P.; MEDRADO, M.A.;PATERNOSTRO, M. A. N. A violência contra a mulher: uma questão de saúde. In: Labra, E. (Org.) Mulher, Saúde e Sociedade no Brasil. Petrópolis, Vozes, 1989.

GREGORI, M. F. Cenas e queixas. Um estudo sobre mulheres, relações violentas e a prática feminista. Rio de Janeiro: Paz e Terra/ANPOCS. 1992

GRISSO, J.; SCHWARZ, D.F>; HIRSCHINGER, M.A>; SAMMEL, M.; BRESINGER, C.; SANTANNA, J.; LOWE, R. a; ANDERSON, E.; SHAW, L.M.; BETHEL, C. ; TEEPLE, L. Violent Injuries among Women in a Urban Area The New England Journal of Medicine, v.341, n. 25, 1999.

GROSSI, M. O significado da violência nas relações de gênero no Brasil. Sexualidade Gênero e Saúde . Rio de Janeiro, CEPESC/IMS/UERJ, 2 (4) dez. 1995.

GUIA DE SERVIÇOS PARA O ATENDIMENTO A MULHERES EM SITUAÇÃO DE VIOLÊNCIA. Coletivo Feminista Sexualidade e Saúde/Centro de Saúde Escola Samuel B. Pessoa/USP. São Paulo, 1999 (2a ed).

HABERMAS, J. O conceito de poder de Hannah Arendt. In: Freitag, B.; Rouanet, S. P. (Orgs) Habermas - Coleção Grandes Cientistas Sociais (15), São Paulo, Ática, 1980, p. 100-118.

HABERMAS, J. Técnica E Ciência Como Ideologia, Lisboa, Edições 70, 1987.

HEISE, L. Violence against women-Global organizing for change. In: Edleson, J.L.; Eisikovits, Z.C. (eds) Future interventions with battered women and their families. Thousand Oaks/London/New Delhi, SAGE, 1996.

HEISE, L.; PITANGUY, J.; GERMAIN, A. Violence against women. The hidden health burden. The international Bank for Reconstruction and Developement/The World Bank, Washington, 1994. 
HELLER, A Para mudar a vida - felicidade, liberdade e democracia. São Paulo, Ed. Brasiliense, 1992.

HELLER, A Teoria de las necessidades en Marx. Barcelona, Editora Península, 1986.

ILICH, I. A Expropriação da Saúde. Rio de Janeiro, Nova Fronteira, 1975.

JOXE, A. Introducción general In: La violência y sus causas. Paris, UNESCO, 1981.

KOSS,M.M. KOSS, P.K.\& WOODNUFF, W.J. Deleterious effects of criminal victimization on women's health and medical utilization. Archives of Internal Medicine, 151, 1991:342-347.

KURZ, D. Violence against women or family violence? Current debates and future directions. In: O’Toole, L.L.; Schiffman, J.R.(eds) Gender Violenceinterdisciplinary perspectives. New York and London, New York University Press, 1997.

KYRIACOU,D.N.;ANGLIN, D.; TALIAFERRO,E.; STONE,S.; TUBB,T.; LINDEN,J. a ; MUELLEMAN, R.; BARTON, E.; KRAUS, J. F. Risk Factors for Injury to Women from Domestic Violence. The New England Journal of Medicine, v.341, n. 25, 1999

LYSTAD, M. (ed) Violence in the home: interdisciplinary perspectives. New York, Brunner/Mazel, 1986.

MCCAULEY ET ALL. The "Battering Syndrome": Prevalence and Clinical Characteristics of Domestic Violence in Primary Care Internal Medicine Practices. Annals of Internal Medicine, 123(10):737-746, November, 1995. 
MCFARLANE, J.; PARKER,B.; SOEKEN, K.; BULLOCK, L Assessing for Abuse During Pregnancy - Severity and Frequency of Injuries and Associated Entry Into Prenatal Care. IAMA June 17, vol.267, no23 pp.3176-3178, 1992.

MCLEER, S.V. The role of the emergency physician in the prevention of domestic violence. Annals of emergency medicine, 16, 1987: 1155-1151

MENDES-GONÇALVES, R.B. Práticas de saúde: processos de trabalho e necessidades. Cadernos CEFOR, Série textos 1, São Paulo, CEFOR-SMS/SP, São Paulo, 1992.

MENDES-GONÇALVES, R.B. Tecnologia e organização social das Práticas de Saúde: Características tecnológicas do processo de trabalho na Rede Estadual de Centros de Saúde de São Paulo. São Paulo, Hucitec/ABRASCO, 1994.

MENDES-GONÇALVES,R.B; SCHRAIBER,L.B.; NEMES, M.I.B. Seis Teses Para A Ação Programática Em Saúde. in:SCHRAIBER, L.B. (Org) Programação em saúde hoje. Saúde em Debate - Série Didática. São Paulo, Hucitec, 1990.

MINAYO, M. C. A violência Social sob a perspectiva da Saúde Pública. Cadernos de Saúde Pública, 10 (supl. 1): 07-18, 1994.

MINAYO, M.C. O desafio do conhecimento. Pesquisa qualitativa em saúde. São Paulo, Hucitec/ ABRASCO, 1992.

MINAYO, M.C.S; SOUZA, E.R. É possível prevenir a violência? Reflexões a partir do campo da saúde pública. In: Ciência \& Saúde Coletiva. ABRASCO. Vol 4 n.1 1999.

MINISTÉRIO DA SAÚDE, Secretaria de políticas de saúde da mulher. Câmara Temática sobre Violência Doméstica e Sexual. Brasília, Ministério da Saúde, 1999. mimeo 
NATIONAL RESEARCH COUNCIL CROWELL, N \& BURGESS, A.W. (ED). Understanding Violence against women - Panel on research on violence against women. Washington, National Academy Press, 1996.

NIJ/CDC Prevalence, incidence, and consequences of violence against women : findings from the national violence against women survey. Research brief. November, 1998.

NORTON,L. ET AL Battering in Pregnancy: An assessment of two screening methods. Obstetrics and Gynecology, 85 (3): 321-325, march 1995.

O’TOOLE, L.L.; SCHIFFMAN, J.R.(eds) Gender Violence-interdisciplinary perspectives. New York and London, New York University Press, 1997.

OEA. Convenção interamericana para prevenir, punir e erradicar a violência contra a mulher- Convenção de Belém do Pará. São Paulo, CLADEM/IPÊ, 1996.

OLIVEIRA, F. A violência contra a mulher é também uma questão de saúde pública: o debate e as políticas de saúde. Mimeo, 1999.

OMS/OPS. Violencia contra a mulher. Un tema de salud prioritario. Division de Salud Familiar y Reproductiva/OMS; Division de salud y desarrollo humano, OPS. 1998.

PEDUZZI, M. Equipe multiprofissional de saúde: a interface entre trabalho e interação, 1998. Tese de Doutorado. Campinas: Faculdade de Ciências Médicas da Unicamp.

PETCHESKY, R. Corpo: direitos sexuais e reprodutivos- uma avaliação no limiar do novo milênio. In: Documento final do $8^{\mathrm{o}}$ Encontro Internacional Mulher e Saúde. Rede Nacional Feminista e de direitos reprodutivos, Rio de Janeiro, 1997. 
RED DE SALUD DE LAS MUJERES LATINOAMERICANAS Y DEL CARIBE. Por el derecho a vivir sin violencia. Acciones y propuestas desde las mujeres. Cuadernos mujer y salud, 1. 1996.

RICOUER, P. Teoria da Interpreetação. Lisboa, edições 70, 1976.

RIVERA, F.J.U. Agir Comunicativo e Planejamento Social (uma crítica ao enfoque estratégico). Rio de Janeiro, Ed. FIOCRUZ, 1995.

RODRIGUEZ, M.A; BAUER, H.M.; MCLOUGHLIN, A,; GRUMBACH,K. Screening and Intervention for Intimate partner abuse- Practices and attitudes of primary care physicians. JAMA 282 (5) 468-474, 1999.

ROSE, G. Individuos enfermos y poblaciones enfermas. Em: O desafio de la epidemiologia: problemas e lecturas selecionadas: 900-909. Washington, D. C. Publicação científica n0 505, 1988.

ROSEMBERG, M. L.; FENLEY, M.A. (Ed.) Violence in America - A Public Health Approach. New York, Oxford University Press, 1991. p.123-157.

SACHS, CJ; BARAFF, LJ.; PEEK, C. Needs for law enforcement in cases of intimate partner violence in a university ED. Am. Journal of Emergency Medicine, 16(1) 60-3, 1998.

SAFFIOTI, H.I.B. ALMEIDA, S.S. Violência de gênero. Poder e Impotência. Rio de Janeiro, Revinter, 1995.

SALA, A. O registro médico em serviços ambulatoriais: a anotação como componente da técnica em saúde São Paulo, 1999. Tese (Doutorado) Faculdade de Medicina, Universidade de São Paulo. 
SCHEI B.; Bakketeig, I.S. Gynaecological impact of sexual and physical abuse by spouse: a study of a random sample of Norwegian women. Br. J Obstet Gynecol 96, 1379-83, 1989.

SCHRAIBER, L B; D'OLIVEIRA, A F P L Violência, Gênero e Saúde: organização de serviços e tecnologia de atenção integral à mulher, São Paulo, FMUSP,1999a (Relatório final de pesquisa ao CNPq).

SCHRAIBER, L B; D'OLIVEIRA, A F P L Violência contra mulheres: interfaces com a Saúde, Interface - Comunicação, Saúde, Educação, vol. 3 n.5 pp 11-27, 1999b.

SCHRAIBER, L.B. O médico e seu trabalho. Limites da liberdade, São Paulo, Hucitec, 1993.

SCHRAIBER, L. B. - Pesquisa qualitativa em saúde: reflexões metodológicas do relato oral e produção de narrativas em estudo sobre a profissão médica, Rev. de Saúde Pública 29(1): 63-74, São Paulo, FSP-USP, 1995.

SCHRAIBER, L.B. Medicina tecnológica e prática profissional contemporânea: novos desafios, outros dilemas. 1997 Tese de livre docência : Faculdade de Medicina, USP.

SCHRAIBER, L.B.; NEMES, M.I.B. \& MENDES-GONÇALVES, R.B (Org.) Saúde do Adulto: programas e ações em unidades básicas. São Paulo: Hucitec/FMUSP, 1996.

SCOTT, J. Gênero: uma categoria útil para a análise histórica. Educação e Realidade. 20 (2) jul/dez 1995.

SENNA, D. M. As mil faces de Ananké: o sofrimento feminino e a prática de saúde. São Paulo, 1999. 149 p. Tese (Doutorado) - Faculdade de Medicina, Universidade de São Paulo. 
SMIKLE, C. B.; SOREM, K. A.; SATIN, A. J.; HANKINS, G.D.VPhysical and Sexual Abuse in a Middle-class Obstetric Population Southern Medical Journal (October) vol.89 no10 pp.983-987,(1996).

SOUZA, E.M. Por detrás da violência: um olhar sobre a cidade. Série textos 7, Cadernos CEFOR - São Paulo, PMSP/SP, 1992.

SOUZA, E.R.; MINAYO, M.C.S. O Impacto da Violência Social na Saúde Pública do Brasil: Década de 80. In: Minayo, M.C.S. (Org) Os muitos Brasis. Saúde e população na década de 80. Rio de Janeiro, Hucitec-Abrasco, 1995.

STARK, E.; FLITCRAFT, A. Spouse Abuse. In: Rosemberg, M. L.; Fenley, M.A. (Ed.) Violence in America - A Public Health Approach. New York, Oxford University Press, 1991. p.123-157.

STARK; FLITCRAFT. Women at risk. - Domestic violence and women health. Thousand Oaks, London, New Delhi, SAGE, 1996.

STARR, P. A sovereign profession. In: Starr, P. The Social Transformation of American Medicine. The rise of a soverign profession and the making of a vast industry. Cambrige, BasicBooks, 1982.

STEWART, D.E.; CECUTTI, A Physical abuse in pregnancy CAN MED ASSOC J (novembre) vol.149 no9 pp.1257-1263, 1993.

SUGG, N. K; INUI, T. Primary care physicians' response to domestic violence. JAMA, 267 (23). 1992: 3157-3160.

SWIFT, C. Preventing family violence: family-focused programs. In: Lystad, M. (ed) Violence in the home: interdisciplinary perspectives. New York, Brunner/Mazel, 1986. 
TIFFT, L. The failure of intervention and the case for prevention. Boulder/San Francisco/Oxford, Westview Press, 1993.

VERARDO, T. Violência. In: d'Oliveira,A.F.L.; Luiz,O.C.; Sorrentino, S. (Org) Coletânea de textos para o Curso de Capacitação para Atendimento a Mulheres em Situação de Violência. São Paulo, Departamento de Medicina Preventiva - FMUSP/Coletivo Feminista Sexualidade e Saúde, 1995.

VICTORA, C.G. Mulher, sexualidade e reprodução: representações do corpo em uma vila de classes populares em Porto Alegre. Porto Alegre, 203p. Dissertação de mestrado. Antropologia social, Universidade Federal do Rio Grande do Sul 1995. 